\title{
CHAPTER 9. AN INTRODUCTION TO LECTIONARY 299 (A.C. MYSHRALL)
}

Codex Zacynthius, as it is currently bound, is a near-complete Greek gospel lectionary dating to the late twelfth century. Very little work has been done on this lectionary because of the intense interest in the text written underneath. Indeed, New Testament scholars have generally neglected most lectionaries in favour of working on continuous text manuscripts. ${ }^{1}$ This is largely down to the late date of most of the available lectionaries as well as the assumption that they form a separate, secondary, textual tradition. However, the study of Byzantine lectionaries is vital to understand the development of the use of the New Testament text. Nearly half of the catalogued New Testament manuscripts are lectionaries. ${ }^{2}$ These manuscripts show us how, in the words of Krueger and Nelson, 'Christianity is not so much the religion of the New Testament as the religion of its use'. ${ }^{3}$ These lectionaries were how the Byzantine faithful heard the Bible throughout the Church year, how they interacted with the Scriptures, and they open a window for us to see the worship of a particular community in a particular time and place.

\section{THE LECTIONARY}

A lectionary is a book containing selected scripture readings for use in Christian worship on a given day. The biblical text is thus arranged not in the traditional order of the Bible, but in the order of how the readings appear throughout the year of worship. So, not all of the Bible is included (the Book of Revelation never appears in a Greek lectionary) and the

\footnotetext{
${ }^{1}$ Exceptions to this include the Chicago Lectionary Project (for an overview of the project see Carroll Osburn, 'The Greek Lectionaries of the New Testament,' in The Text of the New Testament. Essays on the Status Quaestionis [ed. Bart D. Ehrman and Michael W. Holmes. Second edn. Leiden/Boston: Brill, 2014], 93-113, esp. 100-4, and also Gregory S. Paulson, 'A Proposal for a Critical Edition of the Greek New Testament Lectionary,' in Liturgy and the Living Text of the New Testament, ed. H.A.G. Houghton. T\&S 3.15 [Piscataway NJ: Gorgias, 2018], 121-50, esp. 131-3), the inclusion of lectionaries in UBS4 with Karavidopoulos (see Paulson, 'A Proposal,' 135-7), and the recent works by Jordan (C.R.D. Jordan, 'The Textual Tradition of the Gospel of John in Greek Gospel Lectionaries from the Middle Byzantine Period (8th-11th century),' Unpublished PhD thesis, University of Birmingham, 2009) and Gibson (Samuel J. Gibson, The Apostolos. The Acts and Epistles in Byzantine Liturgical Manuscripts. T\&S 3.18 [Piscataway NJ: Gorgias, 2018]).

${ }^{2}$ Paulson, 'A Proposal,' 121.

${ }^{3}$ Derek Krueger and Robert S. Nelson, 'New Testaments of Byzantium. Seen, Heard, Written, Excerpted, Interpreted,' in The New Testament in Byzantium (ed. D. Krueger and R.S. Nelson. Washington DC: Dumbarton Oaks, 2016), 1-20, here 2.
} 
order of the lections reflects the calendar. Some readings were particularly appropriate for certain times of the year, such as the resurrection narratives at Easter, the infancy narratives at Christmas and so forth.

There are several types of lectionary:

- An Evangelion contains only readings from the Gospels. This can also be referred to as an Evangelistarion (a term generally used before the twentieth century).

- An Apostolos is a manuscript containing only Acts and the Epistles.

- An Evangelion-Apostolos, or Apostolo-Evangelion depending on the order of the contents, contains lections from the Gospels, Acts and Epistles.

There is also variation in the days for which a lectionary has readings. Some contain

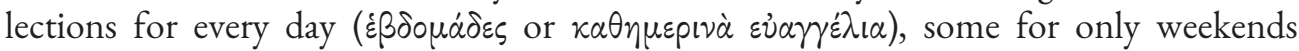

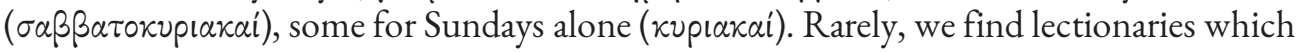
read weekday readings and Sundays. There are also some lectionaries known as Select lectionaries, which are highly individual manuscripts, each with its own purpose. ${ }^{4}$

Most complete lectionaries are divided into two distinct sections; a Synaxarion and a Menologion. The Synaxarion is a lectionary text which follows the moveable ecclesiastical calendar, beginning with Easter Sunday and ending on Holy Saturday. The Menologion follows the fixed civil calendar beginning on September 1 and finishing on August 31. Thus, for any day in the year there are normally two readings in the lectionary, one from the Synaxarion and another from the Menologion.

There are two known cycles of readings; the Constantinople schema and the Jerusalem schema. Due to the process known as Byzantinization, the Jerusalem liturgy came to broadly reflect the Constantinople liturgy over a period of time. ${ }^{5}$ This chapter will focus on the Constantinople type of lectionaries, as this was the most common at the time the Zacynthius lectionary was written. However, it should be remembered that lectionaries do exist with alternative Gospel orders and varying lections.

The Constantinople Synaxarion has five main sections.

- Section 1 reads John from Easter Sunday to Pentecost.

- Section 2 reads Matthew from Pentecost to the Raising of the Cross in September.

- Section 3 reads Luke from Holy Cross Day to Lent.

- Section 4 reads Mark for the Lent weekend readings (the weekday readings are from the Old Testament).

- Section 5 is Holy Week, where readings are taken from all four Gospels.

Small numbers of lections from other Gospels appear in each section, so for instance, the Johannine portion of the Synaxarion is not exclusively all from John.

The Menologion portion of a lectionary contains complementary readings to commemorate various Saints, particular events in the lives of Jesus and Mary, festivals for apostles and great church leaders, earthquakes and dedications of churches. The

\footnotetext{
${ }^{4}$ Gibson, The Apostolos, 4.

${ }^{5}$ For an overview of Jerusalem lectionaries, see Daniel Galadza, Liturgy and Byzantinization in Jerusalem, Oxford: OUP, 2018.
} 
Menologion has a tendency to demonstrate far more variation in the choice of biblical text for each day and the specific commemorations. Some of these variations are geographical, so, for example, lectionaries prepared according to the Constantinople schema often reference the great fire of $465 \mathrm{AD}$ in Constantinople on September 1.

Upon opening Codex Zacynthius, one immediately encounters a problem of terminology. Neither the Synaxarion nor the Menologion are actually identified as such in the manuscript. The term Synaxarion ( $\sigma \nu v \alpha \xi \dot{\alpha}$ pıov) is frequently used by scholars, yet is not written as a title at the beginning of most lectionaries. Contrary to this, we do find the title Menologion ( $\mu \eta \nu$ ○ोó $10 \nu$ ) written at the beginning of the second cycle of readings in some manuscripts. The opening of the Synaxarion frequently begins with the details for the Easter Sunday reading and the evangelist, as we find in Codex Zacynthius. We do however find the term Eklogadion ( $\dot{\varepsilon} \kappa \lambda \circ \gamma a \dot{\delta} \delta 0 \nu$ ) in several manuscripts to describe the Synaxarion portion. The modern printed Eklogadion is a lectionary with Sunday readings, but the name probably comes from the earlier lectionary tradition. ${ }^{6}$ The term Synaxarion is found however, in lectionary tables, tables which list what to read on each day.

\section{DESCRIPTION OF THE MANUSCRIPT}

The Codex Zacynthius lectionary is a daily Gospel lectionary containing both Synaxarion and Menologion, and is identified as Lectionary 299 in the Gregory-Aland system used in the Kurzgefasste Liste. The Synaxarion has all five sections present, so covers the entire liturgical year with readings for nearly every day. The Menologion is also complete, with readings again for every day, and for some days, multiple readings. The only section which is missing is that of the Resurrection readings. These are eleven readings for Sunday Matins beginning on All Saints' Day, normally either found at the end of the Synaxarion, the end of the Menologion or in between Maundy Thursday and Good Friday. Although there are cross-references to these readings throughout Codex Zacynthius, the actual readings themselves are not written. ${ }^{8}$ Commonly, after the Menologion there are also a few lections for special occasions, such as funerals and times of penance. The Zacynthius lectionary does not have any of these. One wonders whether the end of the manuscript is missing and the Resurrection readings should have appeared at the end of the codex.

The manuscript as we have it now measures $28 \mathrm{~cm}$ by $18 \mathrm{~cm}$, an average size for a lectionary. ${ }^{9}$ When the manuscript was palimpsested, the original sheets of the catena were prepared by removing the ink and cut in half to form new sheets of half the size, which in turn were folded in half as quires and rewritten as a lectionary. The size of the pages probably needed to be reduced for ease of use for the lector in service. The re-use of

\footnotetext{
'Jordan, 'The Textual Tradition of the Gospel of John,' 67.

${ }^{7}$ Its shelfmark is Cambridge, University Library, MS Add. 10062. In the online Diktyon catalogue, it has the number 73427.

${ }^{8}$ Cross-references can be seen on folia $1 \mathrm{v}, 17 \mathrm{v}, 18 \mathrm{r}, 21 \mathrm{r}, 163 \mathrm{v}$ and $168 \mathrm{r}$. On fol. $7 \mathrm{r}$ the scribe has added marginal rubrics to mark the beginning of Resurrection reading 2 within the lection for Synaxarion 1 Week 3 Day 1.

'Jordan, 'The Textual Tradition of the Gospel of John,' 122.
} 
parchment to make a new book is not unusual for this time period, especially within a provincial setting with less available funds for new parchment. During the ink removal process, more effort was made to remove the red ink of the catena titles than the brown ink of the catena text; the additional scraping of the parchment in these places can still be seen. Perhaps the red ink was seen as more of a distraction to reading the overtext than the subtle brown ink of the catena undertext, or was less faded due to age.

The manuscript is bound in a sixteenth-century Greek-style goatskin cover, which bears the traces of a cross and four circular decorated motifs (see Image 9.1). On the righthand side of the cover towards the top a peg sticks out, where originally a small strip of leather was attached to the back cover and fixed round to the front to keep the book closed. It looks like a second peg may have been lost from the bottom of the cover, leaving a small hole. The rebinding, or re-covering, of a late twelfth-century manuscript in the sixteenth century shows that this manuscript was still being used, or considered valuable, several hundred years after it was written. The main cover to the manuscript has also been repaired, with small stitches visible across the top left of the front cover and across the back cover. This suggests ongoing use after the sixteenth-century cover was added. A number of marginal notes in later hands confirm the use of the manuscript over several centuries. ${ }^{10}$

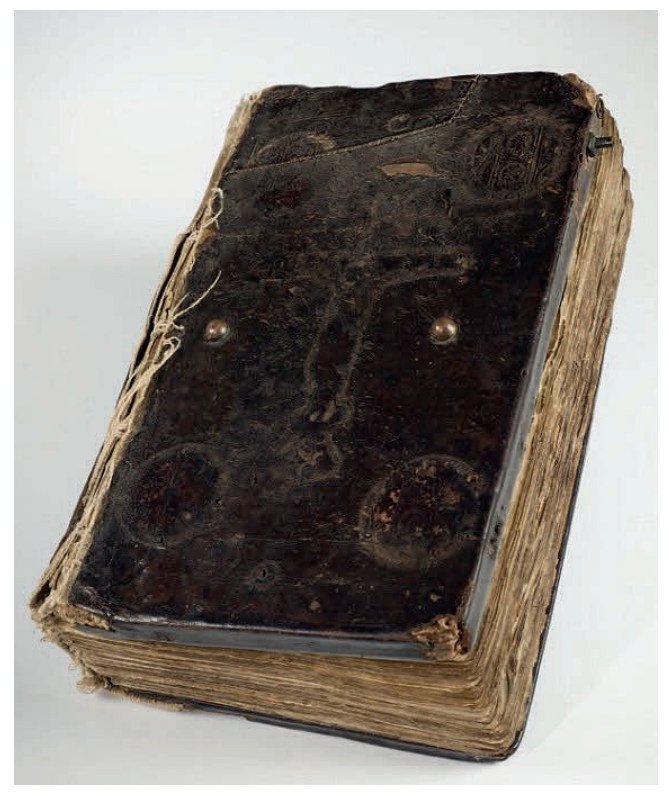

Image 9.1: The front cover of Codex Zacynthius showing decorations and repair work

The manuscript is quite thick, containing 175 parchment leaves. One further leaf (folio 173) is a paper supplement making 176 folia in total, and several leaves on either side of this have repairs. ${ }^{11}$ These repairs may be dated to the fourteenth century by the

\footnotetext{
${ }^{10}$ See folia $51 \mathrm{r}, 90 \mathrm{v}, 120 \mathrm{v}$ and $130 \mathrm{v}$.

${ }^{11}$ Folia 171, 172 and 174 are patched.
} 
watermark of folio 173, which consists of a bow and arrow pointing vertically upwards. Although the device is relatively common, the closest match for it is found in paper used in Pisa and Florence dated $1364 .{ }^{12}$ Occasional holes can be found throughout the lectionary, many of which must have occurred before the palimpsesting of the manuscript because the scribe of the lectionary has written around them. An example of the copyist avoiding places of corrosion is shown in Image 9.2. Deterioration like this is common in parchment manuscripts, and in this case must pre-date the lectionary. It seems that the ink of the undertext continued to corrode after the palimpsesting process because it had not been sufficiently well-removed: writing in the lectionary overtext has sometimes been partly lost due to this.

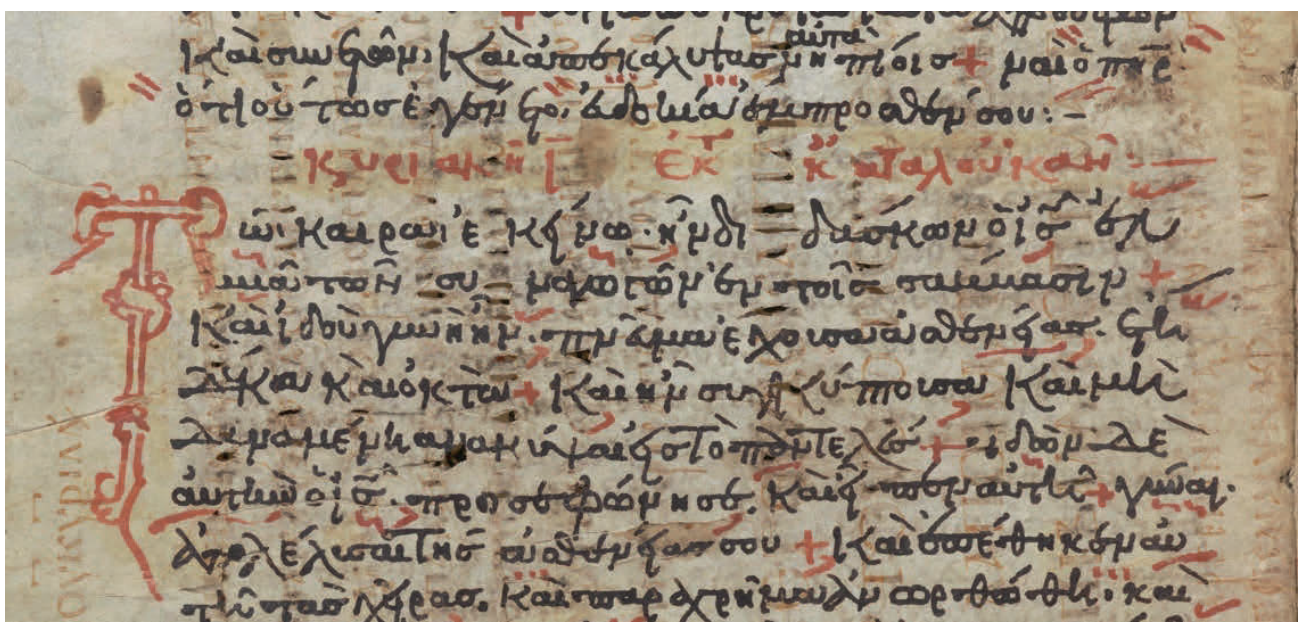

Image 9.2: Folio 78v showing how the lectionary was written around ink corrosion from the catena undertext

The text of the lectionary is the work of a single scribe, written in a single column of normally between 33 and 36 lines. The hand itself is similar to the 'epsilon style' common to the Eastern Mediterranean region. ${ }^{13}$ Lectionaries are commonly written in two columns, which aided the reader in moving from line to line. The single column format of Zacynthius is not unusual for a lectionary, but it is less common than the two-column format. ${ }^{14}$ The text block itself is reasonably compressed so is not like the large format display lectionaries which have few lines per page and large letters. ${ }^{15}$ Nor is it illustrated in

${ }^{12}$ Vladimir A. Mošin and Seid M. Traljić, Filigranes des XIIIe et XIVe siècle/Vodeni znakovi XIII $i$ $X I V$ vijeka (Zagreb: Yugoslavian Academy, 1957), no. 351. We are grateful to Nigel Wilson for this identification. The design is also very similar to BOW.099.1, record no. 5884 in the online Gravell Watermark Archive, on paper used in Palermo in 1312 (see https://www.gravell.org/ record.php?\&action=GET\&RECID=5884).

${ }^{13}$ For the identification of the copyist, see pages 196-203 below.

${ }^{14}$ Jordan, 'The Textual Tradition of the Gospel of John,' 130.

${ }^{15}$ Cf. Vatican, BAV, Vat. gr. 351 (GA L35), a select lectionary in display format. 
any way. In a practical working text, illuminated pictures would not have been necessary. The appearance of the text hints at a need to use parchment sparingly, by not wasting space between columns or by spreading out the text.

\section{Decoration and Rubrics}

Both red and black ink are used; black for the main text and red for the enlarged initials, headings, decorations, ekphonetic notation (or neumes) used in chanting and some marginal notes. There is little embellishment to the main text other than extending some strokes into the margins, and the occasional use of red crosses to decorate some letters (see Image 9.3). The use of a cross on the centre stroke of an epsilon was also employed in the catena undertext, showing how little decorations had changed in the period between the writing of the two texts.
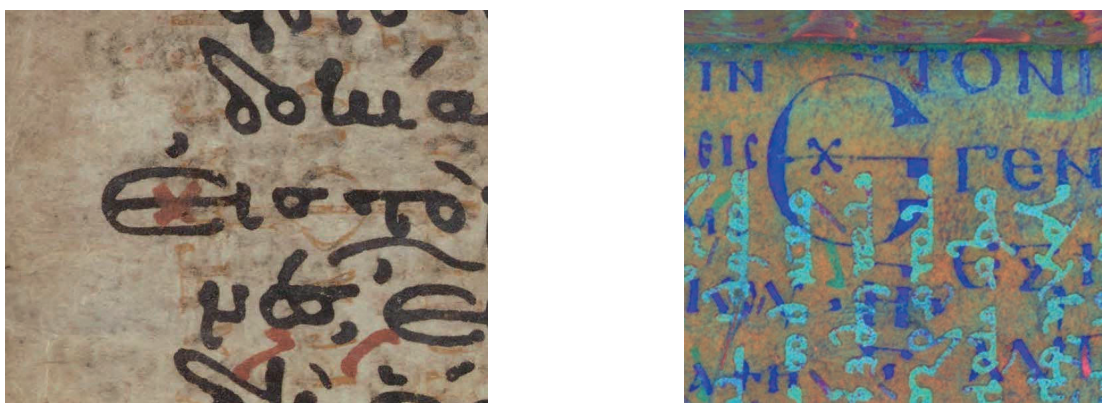

Image 9.3: Folio 157r from L299 and folio 15v from 040, epsilon with cross decoration

Each section of the lectionary begins with a decorative headpiece. The only exception is the start of Synaxarion period 5, which is not decorated or separated in any way: instead, a separation is found later with the Gospels of the Passions between Maundy Thursday and Good Friday. The Hours readings of Good Friday and the Vespers readings are also decorated. Of the large headpieces for Synaxarion periods 1 to 4, the first, for John, is drawn using only red ink (fol. 1r, see Image 9.4). Drawn in the shape of a $p i$ and filled with twisting tendrils, it is not completely symmetrical and looks slightly experimental. This could suggest either an inexperienced scribe, or that this manuscript was not produced at a major scribal centre where drawing headpieces like this would have been commonplace. The second one for Matthew has a much simpler design (fol. 21v, see Image 9.5). This is a band headpiece drawn in red and black ink, with an intertwined wave design. The third headpiece for Luke on folio $57 \mathrm{r}$ uses a smaller $p i$ headpiece with a similar tendril design to that of John (see Image 9.6). The Lent headpiece on folio $105 \mathrm{r}$ combines the $p i$ headpiece of John with the intertwined wave design of Matthew (see Image 9.7). 


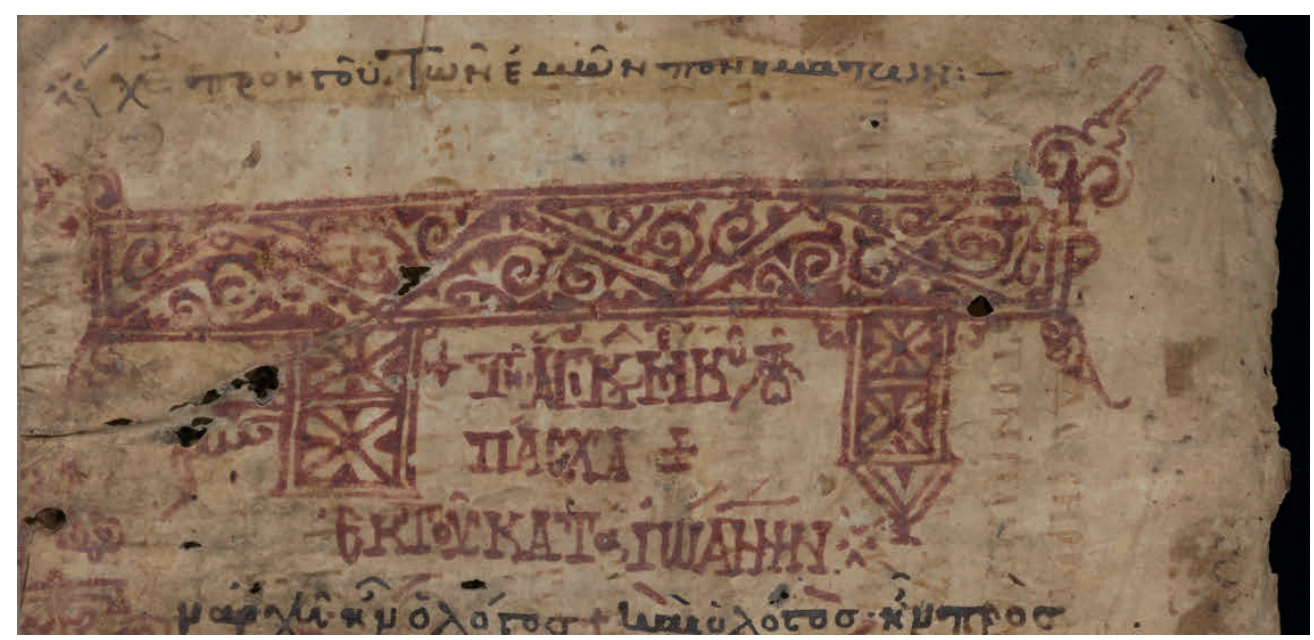

Image 9.4: Folio 1r, John headpiece

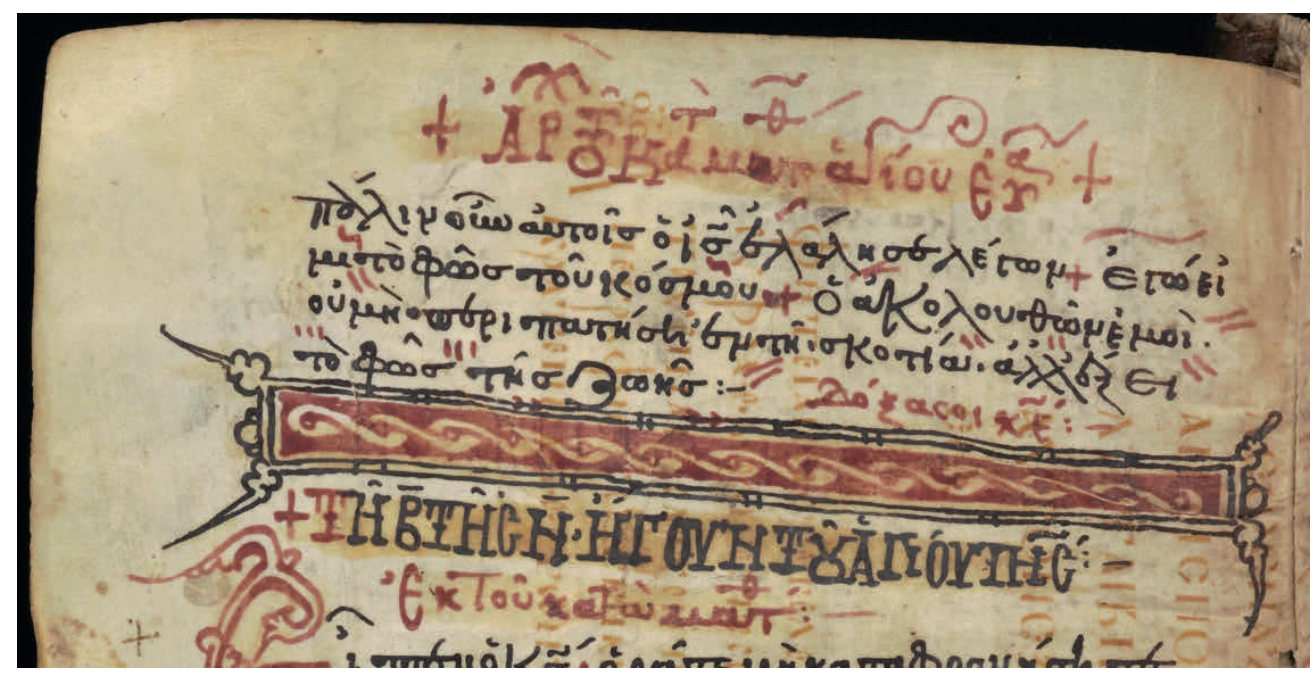

Image 9.5: Folio 21v, Matthew headpiece

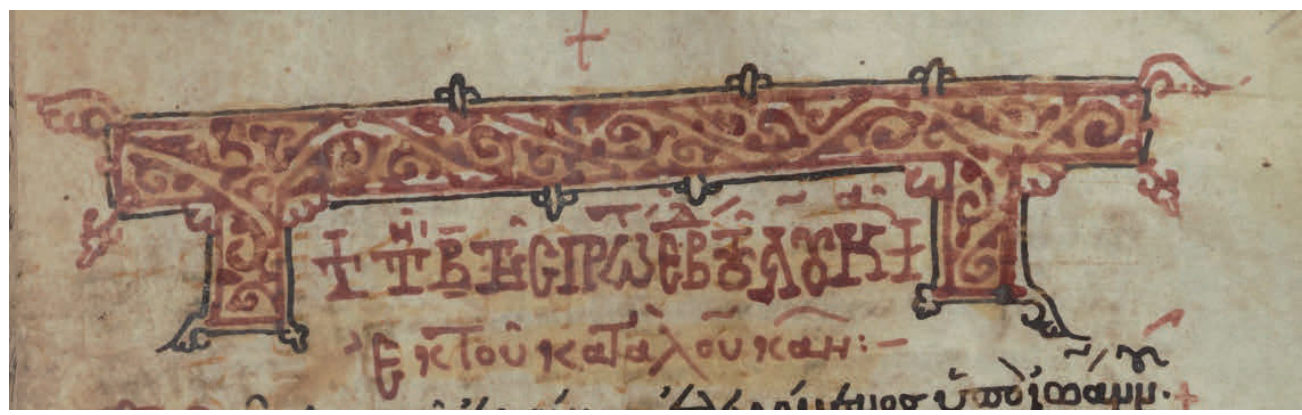

Image 9.6: Folio 57r, Luke headpiece 


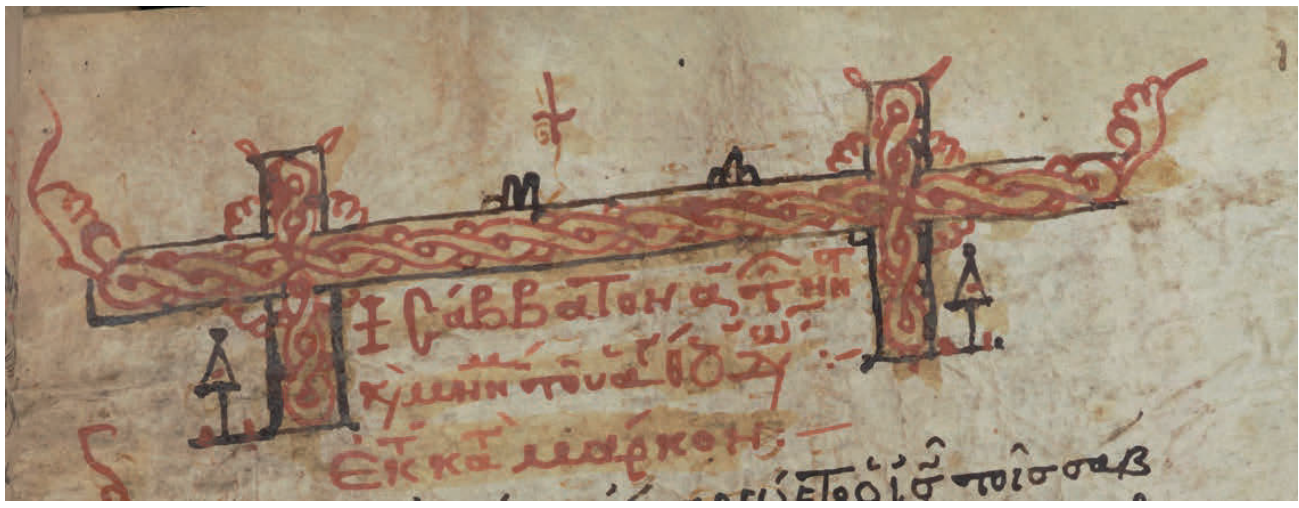

Image 9.7: Folio 105r Lent headpiece

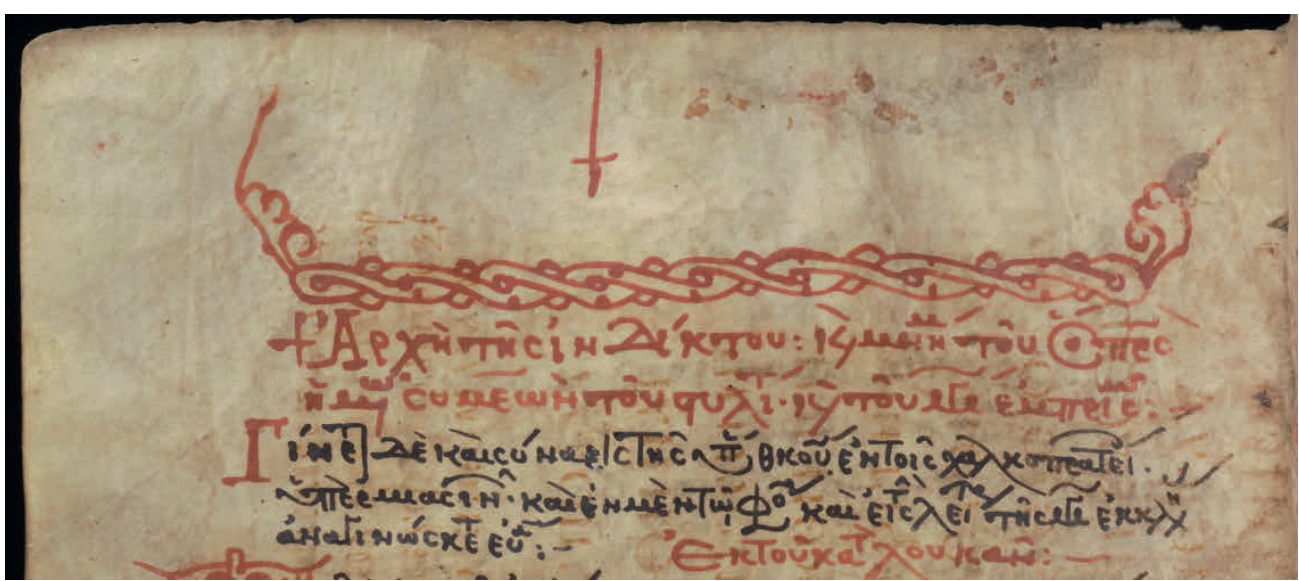

Image 9.8: Folio 144v Menologion headpiece

The headpiece beginning the Menologion on folio 144v (Image 9.8) is a simplified version of the previous design for Lent (Synaxarion period 4, Image 9.7). All of the headpiece designs feature leaf-shaped finials extending from the corners (palmettes) as was typical for Byzantine decoration. The variation may be prompted by different exemplars. Each Menologion month is separated by a simple decoration of tilde shapes and dots in a repeating pattern. Only May and October are exceptions to this. May has small T shapes on either side of a wavy line, which matches the decoration for the Good Friday Night Vigil readings. October is similar to this, featuring a wavy line with dots. If the decoration was not added during the writing of the lections, the amount of space calculated for these was exact. Two of the other decorations are probably space fillers, that on folio $27 \mathrm{r}$ to make the кupıxy reading begin on a new page, and on folio $104 \mathrm{v}$ to fill the space at the end of Synaxarion 3.

Another feature of the lectionary is the enlarged initials beginning each lection (see Image 9.9). The enlarged letters project into the margins (ekthesis) and are written in red ink. It is likely that they were penned at the same time as the main text in black was written, because the text wraps around them with precision: unlike other Greek biblical manuscripts, the enlarged initials do not sit by themselves in the margin, there are no small 
prompts to guide the rubricator and no absent letters. ${ }^{16}$ Even when the red initials extend into the text area, the black text fits them with precision. Furthermore, the spacing of the lectionary text also seems to be accommodated to the red ekphonetic signs above them (see pages 178-9 below). It may therefore be concluded that the scribe had access to both inks as he wrote.

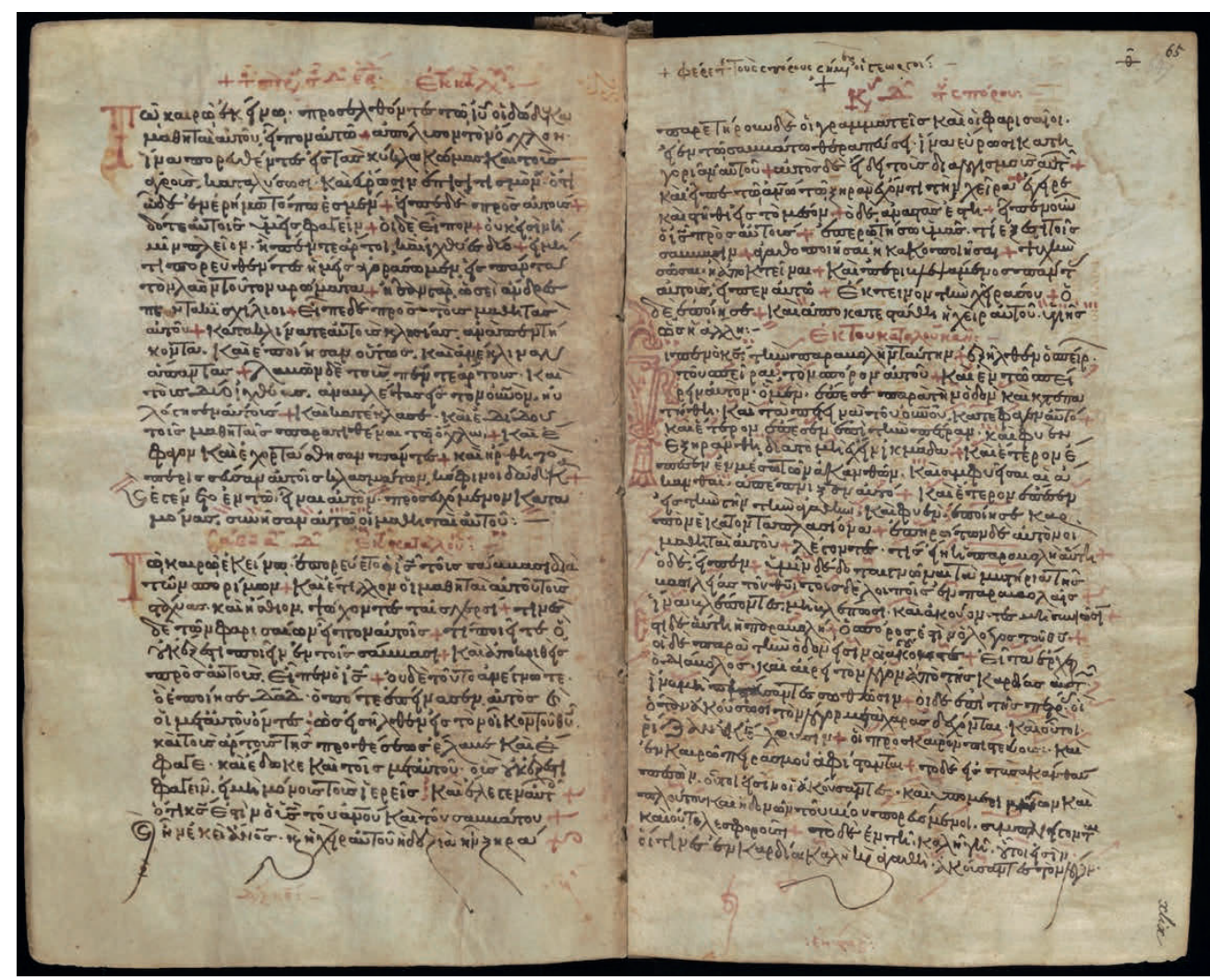

Image 9.9: Folia 64v and 65r, showing different types of enlarged initials

Weekday lections tend to have smaller, simpler initials, but Sunday lections are given prominence with larger and more decorated initials. This pattern continues throughout the lectionary. ${ }^{17}$ This subtle difference makes it easier for the lector to locate where he is in the lectionary and gives prominence to the Sunday lesson. This can be seen on Image 9.9 where the red initials for the weekdays on folio $64 \mathrm{v}$ are simple designs corresponding in height to around three lines of text; opposite them, the Sunday reading on folio $65 \mathrm{r}$ has a

${ }^{16}$ Examples of the small letters left in the margin as prompts for the rubricator may be seen in the manuscript Vatican City, BAV, Ott. gr. 298 (GA 629).

${ }^{17}$ Anderson identifies a similar pattern in GA L1635 with plain gold initials and painted gold initials: J.C. Anderson, The New York Cruciform Lectionary (Pennsylvania: Pennsylvania State University Press, 1992), 25. 
red initial which is far more ornate and extends over ten lines. The same letters appear throughout, commonly $\mathrm{E}$ and $\mathrm{T}$, because each lection begins with a standard incipit. The incipits in Codex Zacynthius are:

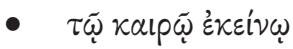

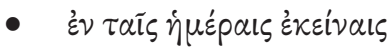

- $\quad \varepsilon i \pi \pi v \delta$ xúplos

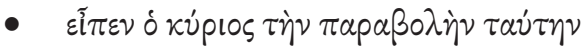

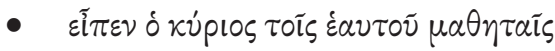

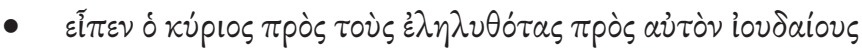

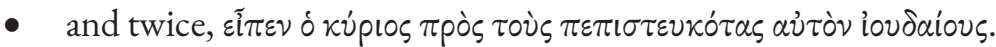

There are some instances of lections which do not include an incipit, leading to other enlarged initials within the codex. An example of this is the first Sunday after Easter, where

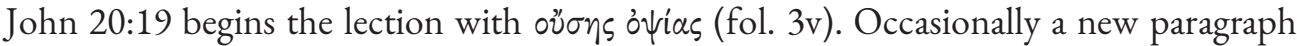
within a lection begins with a much smaller red initial. These often coincide with the beginning of a new lection within the main lection. Also, there are occasions when a new lection begins with the word $\tau \tilde{\omega}$, and the whole word is rubricated and enlarged rather than just the initial letter, e.g. on folio $52 \mathrm{v}$.

Lections written in full in the Menologion still display enlarged initials in red with ekthesis. However, in this part of the manuscript a great number of lections are simply listed with instructions on where to locate them. This leads to an abundance of red letters within the text, not just down the margins where the days are listed. Each new part of a reference begins with a red letter, such as the beginning of the commemoration, the beginning of the cross-reference, the beginning of the service and prokeimena and stichoi. ${ }^{18}$

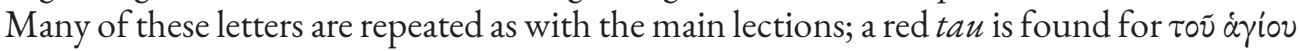

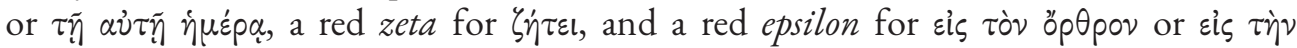
$\lambda \varepsilon i \tau o v p \gamma i \alpha \nu$. Thus, although each new part of a reference does not begin on a new line, the appearance of the text is still easily navigable. (See Image 9.10 for the layout of a page of Menologion instructions.)

In addition to the rubricated initials, Lectionary 299 features an extensive set of red markings above the words, which are part of the ekphonetic notation system, or neumes. These are visible in a number of the photographs in this chapter, such as Image 9.5. The colour and shape of these marks distinguish them from the Greek accents which are written in the same black ink as the text. While accents assist with reading the text, neumes provide the intonation for chanting. The presence of this system, written by the scribe, indicates that Codex Zacynthius was intended to be used for public recitation, with these signs aiding with sense division and cantillation. ${ }^{19}$ The $\tau \varepsilon \lambda \varepsilon i \alpha$ (red marks in the text in the shape of $\mathrm{a}+$ ) have been included in the transcription as they mark the end of passages and sometimes replace the standard punctuation. As already noted, the biblical text is often spaced to allow for the addition of these markings: many of the teleia are written in blank space, although there are also a great number of places where they are squeezed above the last word of a phrase. This suggests that the exemplar used for transcription may not have

\footnotetext{
${ }^{18}$ See pages $189-92$ below.

${ }^{19}$ Gibson, The Apostolos, 169.
} 
been the same as the one for the addition of the neumes, if, indeed, the latter were copied from another manuscript and not simply added through tradition. Some passages are not marked with this notation: it is unlikely that they were not read aloud, so they may have simply been overlooked. ${ }^{20}$ It appears that the text in black writing was copied first and the ekphonetic notation added subsequently, as occasional corrections have been made in red ink.

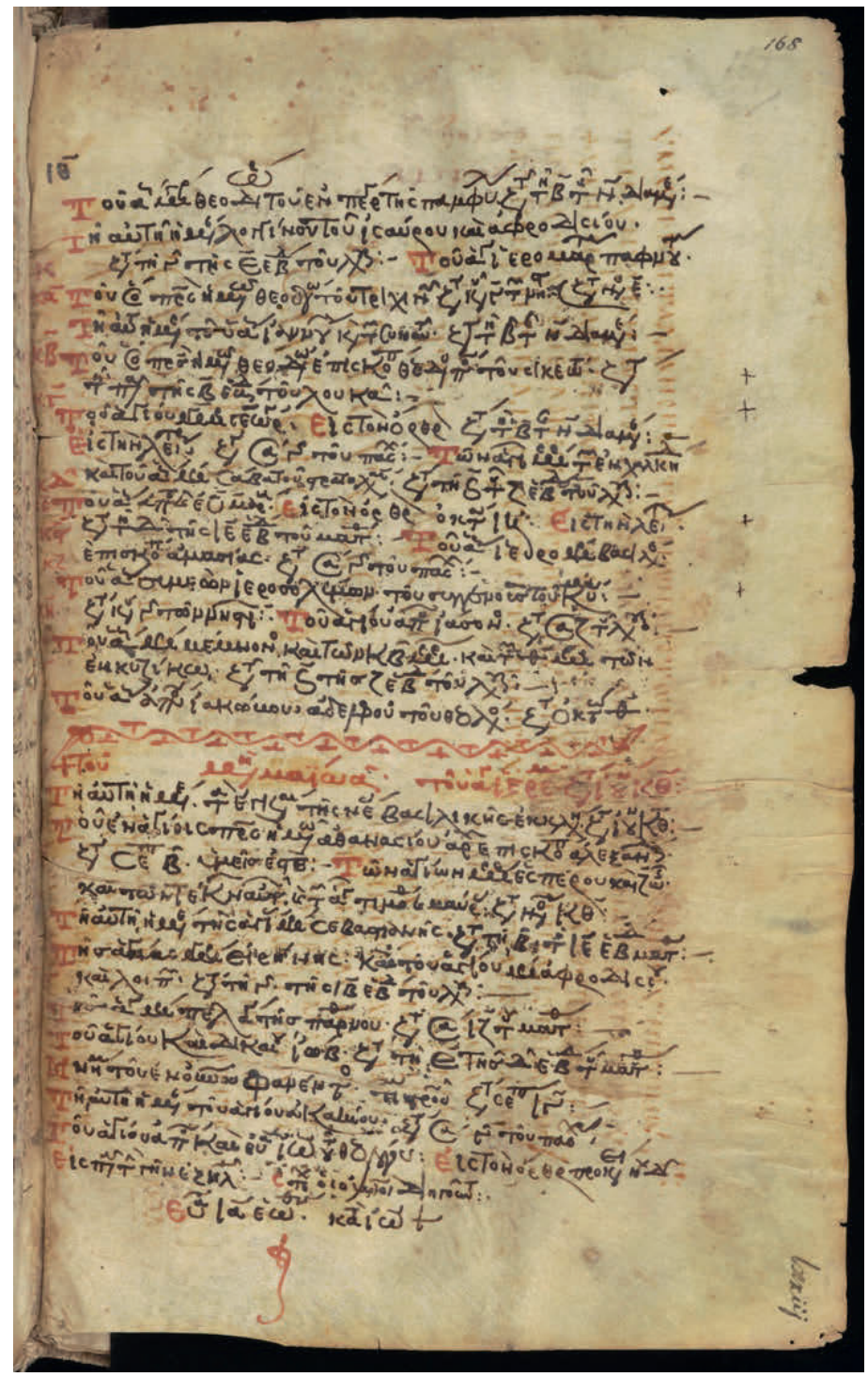

Image 9.10: Folio 168r, showing the lists of readings in the Menologion

\footnotetext{
${ }^{20}$ For an example, see fol. $11 \mathrm{v}$ where the lection at the top of the page lacks neumes, but the lection beginning lower down on the same page has them.
} 
Like many other New Testament manuscripts, the lectionary features diplai in the left margin. These arrow-shaped marks ( $>$ ) identify quotations, enabling the reader to distinguish passages quoted from the Old Testament from the words of the evangelist. A good example can be seen on folio 32r, where a long quote from Isaiah is marked with diplai. In most lections, the selection of text is so short as to not require additional paragraphing. However, some of the longer lections have paragraphs, to assist the lector with the sense and with keeping their place whilst reading aloud. It has already been noted that the scribe begins new mini-lections within the larger lection with a small red letter in ekthesis. There are also numerous places where the scribe puts a black letter in ekthesis in order to break up the text. In some places, this appears rather experimental, such as the lower half of folio 103r, where there are six new paragraphs in only twenty lines (compare also the bottom of folio $114 \mathrm{v}$ ). Although this text does lend itself to being broken into sections, these passages stand out as written in a different way to other lections.

\section{Pagination and Quires}

The first and last pages of the manuscript are particularly worn and hard to read where the ink and parchment have rubbed against the wooden covers. The last page, fol. 176, is particularly interesting because it should come after folio 168: it contains part of the Menologion for May and June and features the quire number 22. It must have come loose at some point and been rebound at the back of the manuscript. Although the date of this is not certain, the wear on this page implies that it has been in its current position for some time. In other places, the binding is rather tight and makes it hard to read some of the text where it sits close to the centre of the book. This can be seen at the bottom left of the very first page. In other places, such as folio $97 \mathrm{r}$, the sheet is becoming detached and the sewing of the binding can be seen at the bottom.

Folio $169 \mathrm{r}$ has been heavily trimmed, presumably in order to supply a strip of parchment for another purpose. Indeed, there is evidence of trimming throughout the codex, such as at the bottom of folio 26r, where a crease has caused a small fold of parchment to escape trimming. Although this has had little effect on the lectionary other than the loss of quire number 17 on folio 129r (see Image 9.11), it may have had a greater effect on the undertext: although the surviving margins of the catena are generous, the original quire numbers have probably been lost, possibly with further marginal material. ${ }^{21}$

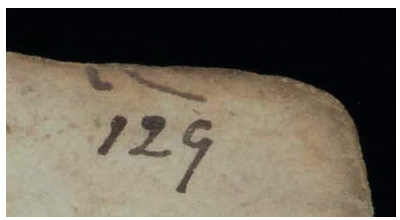

Image 9.11: Folio 129r showing quire number $\iota$ almost entirely trimmed off

${ }^{21}$ For example, the right-hand rows of columns on fol. $1 \mathrm{v}$ of the undertext (fol. $95 \mathrm{v}$ of the lectionary). 
There are three sets of pagination in Codex Zacynthius. Tregelles writes that the manuscript was not previously numerated, and he added Roman numerals for the catena pages and Arabic numbers for the lectionary. ${ }^{22}$ The Roman numerals are in black ink at what would have been the top right-hand corner of the original leaves and thus appear at 90 degrees to the current lectionary. Tregelles' numeration of the lectionary is therefore also likely to be the series in ink, which is correct throughout. Another hand, however, has added a series of pencil numbers to the lectionary in the same place. These are identical until folio 22, where the pencil number 21 is erroneously repeated and all subsequent pencil numbers are out by one (although those on folios $22-26$ have been corrected). It is surprising that an error crept into the pencil numeration when the existing set of ink numbers was correct. For the lectionary transcription the ink numbers have been used.

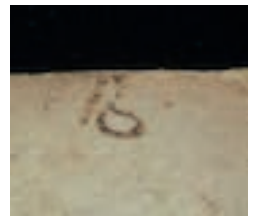

Fol. 9r

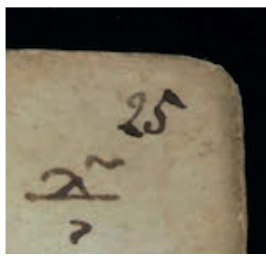

Fol. 25r

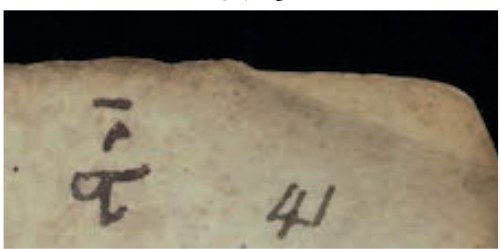

Fol. 41r

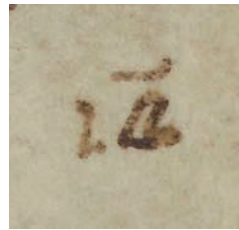

Fol. 96v

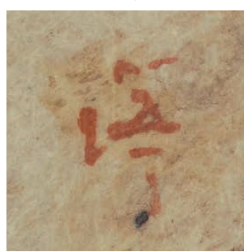

Fol. $112 \mathrm{v}$

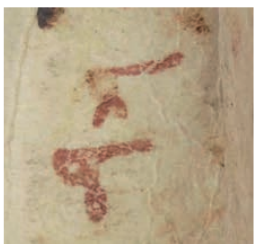

Fol. $48 \mathrm{v}$

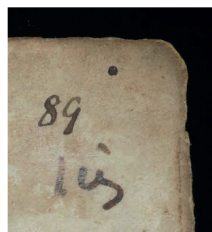

Fol. 89r

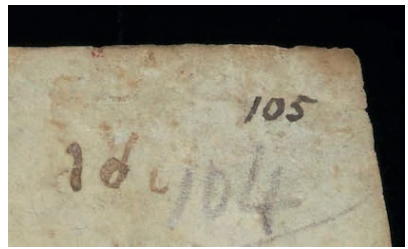

Fol. 105r

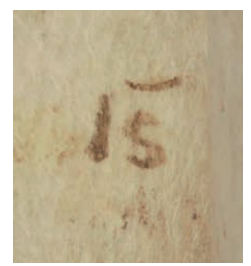

Fol. 128v

Image 9.12: Quire signatures showing letters $\beta, \delta$ and $\varsigma$

The lectionary also contains quire numbers, in order to assist the binder in keeping each quire of material in order. In the lectionary, initial quire signatures in Greek numerals appear at the top right of the first recto page and final quire signatures at the bottom right of the last verso page. Codex Zacynthius employs the system in which the start and end quire numbers match, rather than the end number matching the following quire. There are twenty-two quires of eight pages each. As noted above, the last quire signature is out of order because folio 176 was bound at the end of the codex. At least two hands add the quire numbers, one of whom is the main scribe of the lectionary. This hand uses red and

\footnotetext{
${ }^{22}$ S.P. Tregelles, Codex Zacynthius (London: Samuel Bagster and Sons, 1861), ii.
} 
black ink and regularly adds a numeral hook to the right of the number and decoration underneath, especially for the final signature. It is probable that the same hand was responsible for some of the initial markers, but these are plainer. Some of the numbers display such differences in shape and ink colour that it is clear that at least one additional hand contributed to the numeration (see Image 9.12). The beta at the start of quire 2 (fol. 9r) and quire 12 (fol. 96v) has an enlarged lower bowl, and is distinctly different to the cursive beta at the start of quire 12 (fol. $89 \mathrm{r}$ ). There is also a cursive delta at the start of quire 14 (fol. 105r) which contrasts with other majuscule examples of delta. The differences in the writing of stigma (the numeral 6) are interesting. This is written three times as $\sigma \tau$ (quire 6 start and end, and quire 26 start) but once as $\varsigma$ (quire $16 \mathrm{end}$, fol. $128 \mathrm{v}$ ). It is possible that some of the numbers were added during the rebinding of the manuscript, although it was definitely trimmed after the addition of the quire numbers, as is evidenced by the almost total loss of quire number 17 .

A new section of the liturgical calendar does not necessarily start on a new quire. The beginning of Synaxarion section 2, the portion from Matthew, follows John within the same quire and indeed on the same page (quire 3, fol. 21v). Synaxarion section 3, the Lukan section, begins on a new quire and a new page (quire 8, fol. $57 \mathrm{r}$ ) but this could be coincidence. The first weekday readings of Synaxarion 4 are all instructions to locate the lections elsewhere and appear at the end of folio $104 \mathrm{v}$, the end of quire 13 . This puts the first full reading of Lent on a new page and quire. However, there is no indication of a break between Synaxarion sections 4 and 5 on folio 111v at all, and the lections continue without interruption. The beginning of the Menologion occurs on the last page of quire 18 (fol. 144v) and is not separated. Each month then follows on, saving as much space as possible. This supports Jordan's theory that sections of a lectionary do not have to begin on a new gathering, although there is some evidence of some sections beginning on fresh quires. ${ }^{23}$ It may also suggest that the scholarly segmentation of the Synaxarion into sections may not have been the way the church year was understood during Byzantine times.

\section{THE CONTENTS OF LECTIONARY 299}

The contents of the lectionary in Codex Zacynthius are summarised for easy reference in Table 9.1 (more detailed listings are provided in the lists at the end of this chapter).

\begin{tabular}{|l|l|}
\hline Folio number & Contents \\
\hline $1 \mathrm{r}$ & The beginning of Synaxarion section 1: John. (Easter.) Pi headpiece. \\
\hline $21 \mathrm{v}$ & $\begin{array}{l}\text { The beginning of Synaxarion section 2: Matthew. (Pentecost.) Band } \\
\text { headpiece. }\end{array}$ \\
\hline $57 \mathrm{r}$ & $\begin{array}{l}\text { The beginning of Synaxarion section 3: Luke. (Elevation of the } \\
\text { Cross.) Pi headpiece. }\end{array}$ \\
\hline $83 \mathrm{r}$ & \begin{tabular}{l} 
The beginning of Mark within Synaxarion 3. No decoration. \\
\hline $104 \mathrm{v}$
\end{tabular} \\
$\begin{array}{l}\text { The beginning of Synaxarion section 4: Mark. Initial lections are all } \\
\text { cross-references. }\end{array}$ \\
\hline $105 \mathrm{r}$ & First full lection of Synaxarion 4: Mark. (Lent.) Pi headpiece. \\
\hline
\end{tabular}

${ }^{23}$ Jordan, 'The Textual Tradition of the Gospel of John,' 9. 


\begin{tabular}{|l|l|}
\hline $111 \mathrm{v}$ & The beginning of Synaxarion section 5: Holy Week. No decoration. \\
\hline $126 \mathrm{r}$ & $\begin{array}{l}\text { The beginning of the twelve Gospels of the Passions. These were read } \\
\text { during a vigil from Maundy Thursday to Good Friday. Decoration. }\end{array}$ \\
\hline $137 \mathrm{v}$ & $\begin{array}{l}\text { The beginning of the four lections of the canonical hours on Good } \\
\text { Friday. Decoration. }\end{array}$ \\
\hline $140 \mathrm{v}$ & Good Friday Vespers reading. Decoration. \\
\hline $143 \mathrm{r}$ & Sabbath Vespers reading. Decoration. \\
\hline $144 \mathrm{v}$ & The beginning of the Menologion. Band headpiece. September. \\
\hline $149 \mathrm{r}$ & Start of October. \\
\hline $151 \mathrm{v}$ & Start of November. \\
\hline $154 \mathrm{r}$ & Start of December. \\
\hline $159 \mathrm{r}$ & Start of January. \\
\hline $164 \mathrm{r}$ & Start of February. \\
\hline $166 \mathrm{r}$ & Start of March. \\
\hline $167 \mathrm{v}$ & Start of April. \\
\hline $168 \mathrm{r}$ & Start of May. \\
\hline $171 \mathrm{r}$ & Start of July. \\
\hline $172 \mathrm{v}$ & Start of August. \\
\hline $176 \mathrm{r}$ & Start of June. This leaf is displaced and should follow fol. 168v. \\
\hline
\end{tabular}

Table 9.1: Summary of Contents of Lectionary 299.

Each lection in Zacynthius can be navigated by associating the correct text with the correct heading. The lection heading at the top of the page goes with the first new lection on that page, and any subsequent lections beginning on the same page have their headings written next to them. In addition, the evangelist is normally specified, allowing the reader to locate the day within the correct Synaxarion period. These headings are often heavily abbreviated, giving the day, the week and the evangelist. An example of this would be $\tau \eta$ $\pi \alpha \tau \eta s \gamma \varepsilon \beta \delta \kappa \alpha \tau \lambda$ ouk, which is the reading for the Friday ( $\pi \alpha$ p $\left.\alpha \sigma \kappa \varepsilon v \eta^{\prime}\right)$ of the ( $\left.\tau \tilde{\eta} s\right)$ third $(\gamma)$

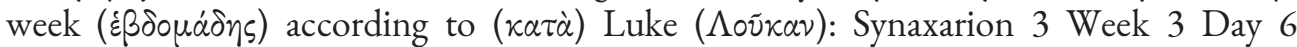
(abbreviated as S3W3D6 in tables and transcriptions). Typical abbreviations in this manuscript include:

- $\sigma \alpha$ for $\sigma \alpha \beta \beta \alpha \dot{\tau} \omega$ (Saturday)

- $\quad x v$ for кupiaxí (Sunday)

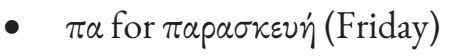

- $\varepsilon \beta \delta$ for $\varepsilon \dot{\beta} \delta 0 \mu \alpha \dot{\delta} \delta$ (week)

- $\nu$ for $\pi \varepsilon v \tau \eta \kappa o \sigma \tau \tilde{\eta} s$ (Pentecost)

- $\mu \varepsilon \sigma o \nu$ for $\mu \varepsilon \sigma o \pi \varepsilon v \tau \eta{ }^{2} \circ \sigma \tau \tilde{\eta} s$ (Mid-Pentecost)

- $\nu \eta \sigma \tau \varepsilon l$ for $\nu \eta \sigma \tau \varepsilon i \omega \nu$ (Lent)

- $\quad k \alpha \tau$ for $\kappa a \tau \dot{\alpha}$ (according to)

- $\mu \alpha \tau \theta$ for $\mu \alpha \tau \theta a$ ĩov (Matthew)

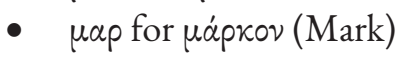


- $\lambda$ ouk for $\lambda$ oṽkav (Luke)

- $\quad \omega \omega$ for i $\omega \alpha \dot{\nu} \nu \eta \nu$ (John)

The service is not normally specified in the heading, as most Gospel lectionaries were read during Divine Liturgy. Only on days with more than one reading are service identifiers written. These are also sometimes abbreviated:

- $\quad$ op $\theta$ for öp $p$ pos (Matins, sometimes also written as $\pi \rho \omega i$ )

- $\lambda \varepsilon i \tau$ for $\lambda \varepsilon \varepsilon \tau o u p \gamma i \alpha \nu$ (Liturgy)

- $\varepsilon \sigma \pi$ for $\dot{\sigma} \sigma \varepsilon \dot{\varepsilon} \rho a_{\text {(Vespers) }}$

- $\quad \alpha \pi \circ \delta \varepsilon \varepsilon \pi$ for $\alpha \pi$ ò $\delta \varepsilon i \pi \nu \nu \nu$ (Literally 'after dinner', so Compline)

- $\omega p$ for $\ddot{\omega} \rho a$ (Hours).

On occasion, specific days have their own titles which would have been known to the

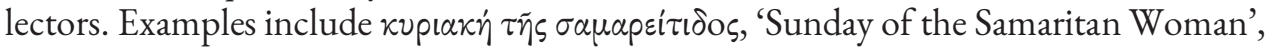

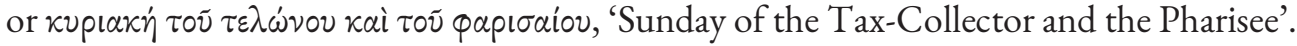
Other titles seen more than once in this lectionary include:

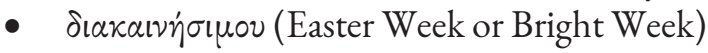

- $\pi \dot{\sigma} \sigma \alpha \alpha$ (Easter)

- $\pi$ posóptiov (forefeast)

- $\mu \varepsilon \theta \varepsilon o ́ p \tau i o v$ (after-feast)

- $\tau \alpha \varphi \dot{\omega} \tau \alpha$ (divine lights; Theophany or Epiphany).

The Synaxarion readings follow two patterns of lections. Weekend readings follow each other (Saturdays to Saturdays and Sundays to Sundays) in a relatively sequential pattern, while the weekday readings follow a separate sequence. This is quite normal for a Byzantine lectionary, but when the lections are listed by contents, the jumps backwards within a gospel for the weekend readings can be quite striking. Krueger and Nelson suggest that this was caused by combining an older system for weekend readings with a newer arrangement for weekdays. ${ }^{24}$ As would be expected for a twelfth-century manuscript, Codex Zacynthius follows this combined system.

Many lections are repeated by having two different calendars of readings. To avoid duplication, scribes came up with a system of cross-referencing which saved both time and space. On numerous occasions, largely in the Menologion, the lection heading is given and then, after the word ¿ทं $\tau \varepsilon$ meaning 'seek', the reference of where the full text of that passage can be found in the lectionary. These cross-references are often heavily abbreviated.

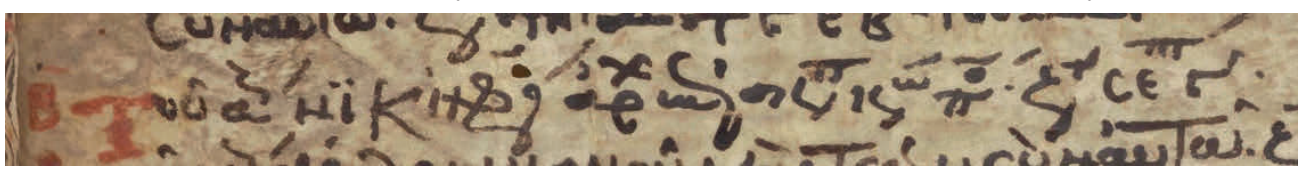

Image 9.13: Folio 176r June 2 abbreviations

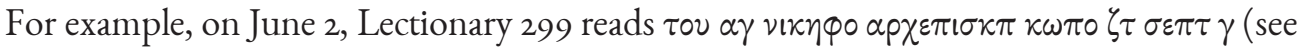

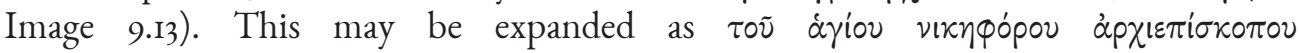

${ }^{24}$ Krueger and Nelson, 'New Testaments of Byzantium,' 11. See also Osburn, 'The Greek Lectionaries,' 105. 


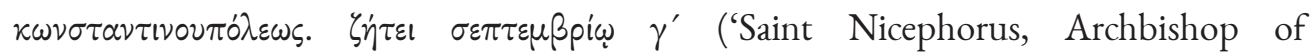
Constantinople. Seek September 3.'). A full list of the Menologion headings for this manuscript is provided at the end of this chapter to assist with navigating these abbreviations.

The lections given in full in the Menologion do not have any particular liturgical significance. They are written out either because that passage had not previously occurred in the codex so needed a full lection, or because the verse spread needed was complex and

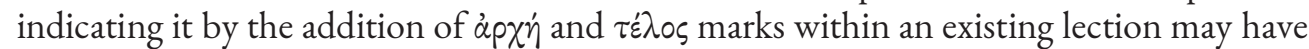
caused confusion. The texts written in full in the Menologion are listed in Table 9.2. Specific services for the day are noted if appropriate. Errors in the evangelist ascriptions in the titles are recorded in quotation marks, with the correct source given in the reference. There are more incorrect ascriptions in the Menologion than the Synaxarion, probably because of the regularity of the sequence of the gospels within the Synaxarion which contrasts with the lack of order in the Menologion. ${ }^{25}$ Lections with only the initial words of the first verse are not included in Table 9.2, as these initial incipits are simply a marker. For example, references to Matthew 5:14-19 include the words $\dot{u \varepsilon \varepsilon} \varsigma$ $\dot{\sigma} \tau \varepsilon$ after the instruction to seek the passage for September 2. This shows the reader that the lection required is the second one on that day, from Matthew, not the first one (John 15:1-7).

\begin{tabular}{|l|l|}
\hline Day & Text \\
\hline Sept. 2 & Matthew 5:14-19 \\
\hline Sept. 3 & John 10:9-16 \\
\hline Sept. 8 Matins & Luke 1:39-49, 56 \\
\hline Sept. 8 Liturgy & Luke 10:38-42; 11:27-28 \\
\hline Sept. 13 & John 12:25-36 \\
\hline Sunday before the Elevation of the Cross & John 3:13-17 \\
\hline Sept. 14 & John 19:6, 9-11, 13-20, 25-28, 30-35 \\
\hline Sept. 30 & Matthew 24:42-47 \\
\hline Oct. 8 & John 8:3-11 \\
\hline Oct. 9 & Matthew 10:1-7, 14-15 \\
\hline Oct. 11 & Mark 13:33-37; 14:3-9 ('Luke') \\
\hline Oct. 13 & Matthew 7:12-21 \\
\hline Oct. 18 & Luke 10:16-21 \\
\hline Nov. 1 Liturgy & Matthew 10:1-8 \\
\hline Nov. 5 & Mark 8:34-35; 10:29-31 \\
\hline Nov. 6 & Luke 12:8-12 ('Matthew') \\
\hline Nov. 10 Liturgy & Luke 14:25-27, 33-35 ('Matthew') \\
\hline Nov. 13 Matins & John 10:1-9 \\
\hline
\end{tabular}

\footnotetext{
${ }^{25}$ See also L1635 for this ascription problem in the Menologion: Anderson, The New York Cruciform Lectionary, 72.
} 


\begin{tabular}{|l|l|}
\hline Nov. 29 & $\begin{array}{l}\text { Matthew 10:17-18, 23-25, 28-31 } \\
\text { ('Mark') }\end{array}$ \\
\hline Dec. 17 & Luke 11:44-50 \\
\hline Sunday before Christmas Day & Matthew 1:1-25 \\
\hline Dec. 24 (3rd hour) & Luke 2:1-20 \\
\hline Dec. 25 Liturgy & Matthew 2:1-12 \\
\hline Dec. 26 & Matthew 2:13-23 \\
\hline Saturday after Christmas Day & Matthew 12:15-21 \\
\hline Jan. 1 Liturgy & Luke 2:20-21, 40-52 \\
\hline Jan. 3 & Matthew 3:1, 5-11 \\
\hline Saturday before Epiphany & Matthew 3:1-6 \\
\hline Sunday before Epiphany & Mark 1:1-8 \\
\hline Jan. 5 & Luke 3:1-18 \\
\hline Jan. 6 Matins & Mark 1:9-11 \\
\hline Jan. 6 Liturgy & Matthew 3:13-17 \\
\hline Jan. 7 & John 1:29-34('Matthew') \\
\hline Saturday after Epiphany & Matthew 4:1-11 \\
\hline Sunday after Epiphany & Matthew 4:12-17 \\
\hline Jan. 9 & Luke 3:21-22; 4:1-2, 14-15 \\
\hline Jan. 12 & John 10:39-42 \\
\hline Feb. 2 Liturgy & Luke 2:22-40 \\
\hline Feb. 15 & Luke 10:3-9 \\
\hline Feb. 23 & John 12:24-26, 35-36 \\
\hline Mar. 25 Liturgy & Luke 1:24-38 \\
\hline May 8 Liturgy & John 19:25-27; 21:24-25 \\
\hline June 19 & Luke 6:20-26; 10:23-24; 11:33 \\
\hline June 24 Liturgy & Luke 1:1-25, 57-68, 76-80 \\
\hline June 29 Liturgy & Matthew 16:13-19 \\
\hline July 8 & Luke 6:17-19; 9:1-2; 10:16-21 \\
\hline Aug. 6 Matins & Luke 9:28-36 \\
\hline Aug. 6 Liturgy & Matthew 17:1-9 \\
\hline Aug. 7 & Mark 9:2-9 \\
\hline Aug. 29 Liturgy & Mark 6:14-30 \\
\hline & \\
\hline & \\
\hline
\end{tabular}

Table 9.2: Gospel Texts Written in Full in the Menologion in Lectionary 299.

A comparison with a similar table for the Jaharis Lectionary (Lectionary 351) shows that fewer passages are written in full in Codex Zacynthius. ${ }^{26}$ The Jaharis Lectionary was written for Hagia Sophia, the cathedral of Constantinople and seat of the Patriarch. While sixty-five lections are given in full in Jaharis, Zacynthius by contrast cites fifty. From an entire year's worth of lections, including multiple readings for many days, this illustrates how few lections were actually penned in full in the Menologion of both manuscripts.

${ }^{26}$ John Lowden, The Jaharis Gospel Lectionary: The Story of a Byzantine Book (New York: The Metropolitan Museum of Art, 2009), Appendix 2 on 116-7. 
The majority of readings for each day correspond exactly, but Zacynthius consistently saves parchment by writing cross-references. On September 1, the first lection of the year, Luke 4:16-22, is written in full in Jaharis, but Zacynthius refers to Synaxarion 3 Week 1 Day 5. On September 6, Mark 12:28-37 in full appears in Jaharis and Zacynthius refers to Synaxarion 3 Week 16 Day 4 after a short incipit. As a general rule, in the earlier part of the year the two manuscripts cite the same lections in full. However, towards the latter part of the year Zacynthius uses cross-references more freely. These cross-references correspond with the same passage as Jaharis with three exceptions:

- June 30: Zacynthius refers to Matthew 10:23-31; Jaharis has the text of Matthew 9:36-10:8

- August 12: Zacynthius refers to Luke 9:1-6; Jaharis has John 12:35-36, 44-50

- August 16: Zacynthius refers to John 15:1-7; Jaharis has the text of Luke 9:5156, 10:22-24, 13:22.

This suggests that the decision to cross-refer in Zacynthius rather than write texts in full was not because of a difference in the expected text but because of a need to save parchment. This may be explained by observing that Jaharis was written for the cathedral of the patriarch, whereas Codex Zacynthius bears the marks of a more provincial production.

The markings for lections used in in continuous text manuscripts can also be found

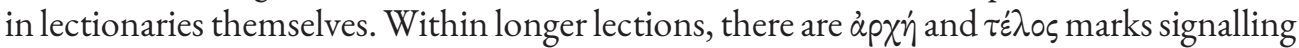
the beginnings and ends of shorter lections. ${ }^{27}$ This occurs when a cross-reference points to a subsection of a longer lection, and the copyist has noted the start and end of this shorter reading to aid the reader. A good example of these markings is found on folio 130r, where the start and end of the reading for July 16, in memory of the Fifth Synod, are noted partway through a lection. Also attached to the marginal notes here is the required incipit for

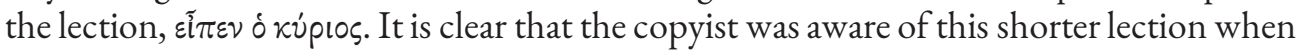
copying the original passage, as its beginning is marked by a new paragraph and red letter in ekthesis. At first appearance, an additional lection marked like this could be presumed to be a secondary addition, but this may not necessarily be the case. The scribe may have followed an exemplar in the way the lections were laid out.

In the lectionary of Codex Zacynthius the cross-references do not always refer backwards to a passage already written. Some are found very early in the Synaxarion and point forwards in the codex to a lection which was yet to be copied. The first example of this is Week 1 Day 3 in John, right at the beginning of the Synaxarion, which instructs the reader to locate this passage from Luke in Resurrection reading 5. However, as mentioned above, the Resurrection pericopes are not extant in this manuscript, so a lector would search in vain. Also, on the very first day, Easter Sunday, there is traditionally a second reading of John 20:19-25. This is not written or referenced at all here in Lectionary 299,

\footnotetext{
${ }^{27}$ For other lectionary abbreviations commonly found, see Teunis Van Lopik, 'Some Notes on the Pericope Adulterae in Byzantine Liturgy,' in Liturgy and the Living Text of the New Testament (ed. H.A.G. Houghton. T\&S 3.16. Piscataway NJ: Gorgias Press, 2018), 151-76, esp. 160.
} 
yet where John 20 is written later in the Synaxarion, the end of this first reading is marked in the margin with a $\tau \dot{\varepsilon} \lambda \iota_{\varsigma}$ sign. There is some confusion in double readings, where a crossreference points the reader to one lection, but a marginal note alongside another lection offers an alternative. For example, the cross-reference for September 5 th points the reader to Synaxarion 2 Week 11 Day 4 (Matthew 23:29-39), yet we find a heading for the beginning of the Saint Zechariah reading beside the same text in Synaxarion 5 Week 1 Day 3a. Or, on folio 116r, the heading of a lection has been changed and additional rubrics added to alter the occasion on which this text should be read, causing confusion over what to read here. ${ }^{28}$ There are even examples of alternative texts for lections, such as on folio 130r where a lection heading in the margin marks the text for July 16 as John 17:11-21, yet the cross-reference in the Menologion list for July 16 (fol. 172r) suggests reading Synaxarion 1 Week 3 Day 7, John 15:17-16:2. The system in Zacynthius is not straightforward, and often relies on the knowledge of the lector to enable use of the manuscript. There are cross-references to days which also have cross-references, leading the reader on a chase around the lectionary to locate the correct reading. By the end of the Menologion, almost entire months are written as headings and instructions, because by this point in the codex most lections have been penned already (compare Image 9.10). This lectionary was written to save space and cost, not to be easy to use.

On some occasions, the instructions are quite complicated. In the middle of the lection for Synaxarion 5 Week 1 Day $6 \mathrm{~b}$ on folio $138 \mathrm{v}$, there are instructions to read the text for the middle portion of the lection elsewhere and then to carry on reading the end of the lection as is written. The instructions after Mark 15:15 may be roughly translated as: 'Seek the sixth Gospel reading of the Passions and read until the end. And again, come back here and begin again with this until the end'. The text then resumes with Mark 15:32. Similarly, on folio $174 \mathrm{v}$ for August 15, the lector is instructed to read two readings together, those of the Matins and the Liturgy on September 8 to make one longer lection. Christmas is a particularly complicated time for this lectionary. On the Saturday before Christmas Day, which elsewhere is normally Matthew 1:1-25, Codex Zacynthius instead has the full text of this passage on the following day (the Sunday before Christmas), and the Saturday has a cross-reference to Synaxarion 3 Week 12 Day 7 (Luke 13:19-29). On December 24th, the Matins reading is marked in the middle of the Matthew 1:1-25 text of this reading for the Sunday before Christmas, and this additional marker apparently also serves for the Christmas Day Matins reading. The additional hours readings for Christmas Eve are not cross-referenced using לทं $\tau \varepsilon l$, but are found in the margins to the readings of Christmas Day Liturgy and the Boxing Day reading. Was this confusion caused by the desire to save parchment or were different strands of lectionary tradition being incorporated into this lectionary?

While lectionaries were used mainly for daily Divine Liturgy and Sunday Matins services, the lectionary system in Codex Zacynthius shows that this book was also used for the monastic hours of Good Friday, throughout Christmas Day, and also for occasional Vigils and Vespers services. ${ }^{29}$ The extra services and lections in this manuscript suggest a

\footnotetext{
${ }^{28}$ See the discussion in the list of selected corrections later in this chapter.

${ }^{29}$ Services for monasteries include Divine Liturgy, Vespers, Compline, Vigils, Matins, 1st, 3rd, 6th and 9th hour services. We find evidence for all of these in Zacynthius.
} 
monastic background either for its provenance or for its intended use. During the Divine Liturgy, the lectionary codex would be carried in procession by the deacon during the Little Entrance; the readings were recited from a lectern outside the bema by a priest or deacon; and the book was placed on the altar. ${ }^{30}$. Weitzmann is the only advocate of the position that decorated lectionaries were for display only and were placed on the altar without being read. ${ }^{31}$ The repair to the cover of Zacynthius, as well as its contents, bears witness to the fact that it was not a display lectionary but a working book.

\section{Prokeimena and Stichoi}

Further evidence for the use of Lectionary 299 during the liturgy is seen in the prokeimena (responsories) and stichoi (Psalm verses) attached to some of the lections. These are the Psalms chanted before and after the lection, with instructions for the chanting tone. Some of these are copied by the original scribe, presumably from an exemplar containing the same information. Others are marginal notes added by later hands to aid in the use of the book, for example on folio 60r beside the lection for Synaxarion 3 Week 2 Day 6. References like these are largely restricted to working texts. There are fewer examples in the Synaxarion of this manuscript, although one is found on folio 110r, the Matins reading for Palm Sunday with text from Psalms 8:2 and 9 (see Image 9.14); instead, they are much more common in the Menologion. Table 9.3 lists the text for each prokeimenon and stichos in the Menologion in Codex Zacynthius, along with a translation and the verse reference both in the Septuagint and in modern Bibles. ${ }^{32}$

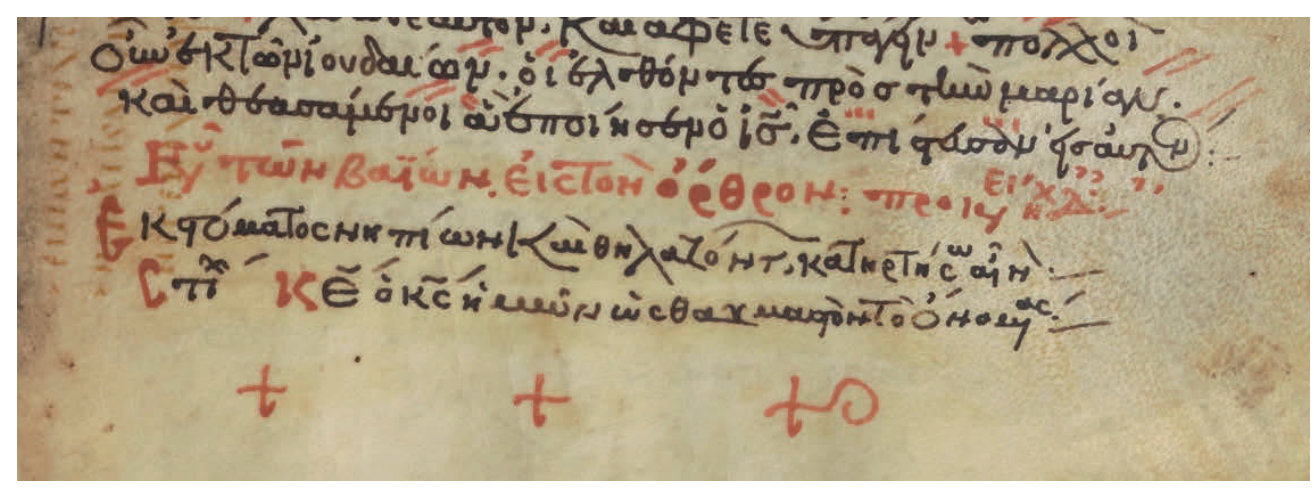

Image 9.14: Folio 110r prokeimenon and stichos readings

\footnotetext{
${ }^{30}$ Jordan, 'The Textual Tradition of the Gospel of John,' 79. On Easter Sunday the readings were recited from the altar table inside the bema by a senior priest.

${ }^{31}$ Jordan, 'The Textual Tradition of the Gospel of John,' 35.

${ }^{32}$ The translation is based on the New English Translation of the Septuagint, Psalms section translated by A. Pietersma. Available online from: http://ccat.sas.upenn.edu/nets/edition/ [Accessed 30.10.2019].
} 


\begin{tabular}{|c|c|c|c|}
\hline \multirow[t]{2}{*}{ Sept. 8} & Prokeimenon & $\begin{array}{l}\mu \nu \eta \sigma \theta \dot{\eta} \sigma \circ \mu(\alpha \iota) \tau o \tilde{v} \text { ò } \nu \text { } \mu(\alpha) \tau(\circ \varsigma) \\
\text { (I will remember [your] name.) }\end{array}$ & $\begin{array}{l}\text { Ps 44:18 } \\
\text { (Ps 45:17) }\end{array}$ \\
\hline & Stichos & 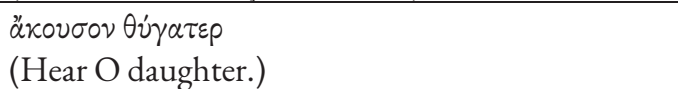 & $\begin{array}{l}\text { Ps 44:11 } \\
\text { (Ps 45:10) }\end{array}$ \\
\hline \multirow[t]{2}{*}{ Sept. 14} & Prokeimenon & 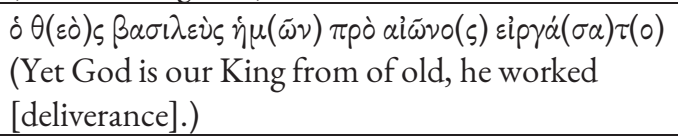 & $\begin{array}{l}\text { Ps 73:12 } \\
\text { (Ps 74:12) }\end{array}$ \\
\hline & Stichos & $\begin{array}{l}\mu \nu \dot{\eta} \sigma \theta \eta \tau \iota \tau \tilde{\eta} s \sigma \nu \nu \alpha \gamma \omega \gamma \tilde{\eta} \varsigma \sigma \circ \nu \tilde{\eta} \varsigma^{\prime} \varepsilon \tau \tau i \sigma \omega \dot{\alpha} \pi^{\prime} \dot{\alpha} \rho \chi(\tilde{\eta} \varsigma) \\
\text { (Remember your congregation, which you } \\
\text { acquired long ago.) }\end{array}$ & $\begin{array}{l}\text { Ps } 73: 2 \\
\text { (Ps 74:2) }\end{array}$ \\
\hline \multirow[t]{2}{*}{ Oct. 22} & Prokeimenon & 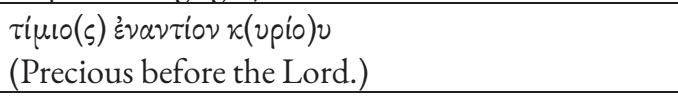 & $\begin{array}{l}\text { Ps 115:6 } \\
\text { (Ps 116:15) }\end{array}$ \\
\hline & Stichos & $\begin{array}{l}\left.\tau^{\prime} \dot{\alpha} \nu \tau \alpha \pi \circ \delta \omega^{\prime}(\sigma \omega) \tau \tilde{\omega}\right) \\
\text { (What shall I return to the Lord.) }\end{array}$ & $\begin{array}{l}\text { Ps } 115: 3 \\
\text { (Ps 116:12) }\end{array}$ \\
\hline \multirow[t]{2}{*}{ Nov. 1} & Prokeimenon & 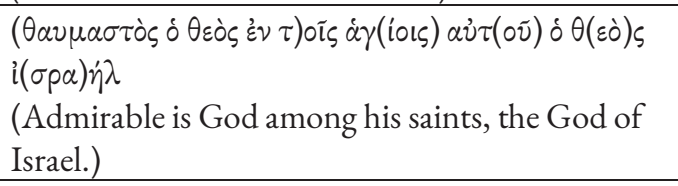 & $\begin{array}{l}\text { Ps 67:36 } \\
\text { (Ps 68:35) }\end{array}$ \\
\hline & Stichos & 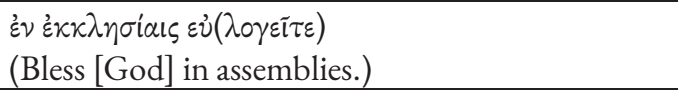 & $\begin{array}{l}\text { Ps 67:27 } \\
(\text { Ps 68:26) }\end{array}$ \\
\hline \multirow[t]{2}{*}{ Nov. 8} & Prokeimenon & 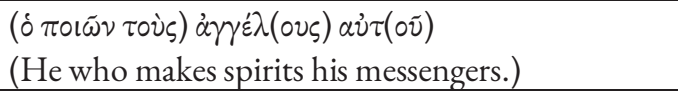 & $\begin{array}{l}\text { Ps 103:4 } \\
\text { (Ps 104:4) }\end{array}$ \\
\hline & Stichos & $\begin{array}{l}\varepsilon \dot{\lambda} \lambda o^{\prime} \varepsilon\llcorner\dot{\eta} \psi v \chi \eta \dot{\eta} \mu(\circ v) \tau(\grave{o} v) \\
\text { (Bless the [Lord], O my soul.) }\end{array}$ & $\begin{array}{l}\text { Ps 103:1 } \\
\text { (Ps 104:1) }\end{array}$ \\
\hline \multirow[t]{2}{*}{ Nov. 10} & Prokeimenon & $\begin{array}{l}\tau i \mu \nu(\varsigma) \dot{\varepsilon} \nu \alpha \nu \tau i(o v) \\
\text { (Precious before [the Lord].) }\end{array}$ & $\begin{array}{l}\text { Ps 115:6 } \\
\text { (Ps 116:15) }\end{array}$ \\
\hline & Stichos & $\begin{array}{l}\tau \tau^{\prime} \alpha \dot{\alpha} \nu \alpha \pi \circ \delta \omega^{\prime}(\sigma \omega) \\
\text { (What shall I return.) }\end{array}$ & $\begin{array}{l}\text { Ps 115:3 } \\
\text { (Ps 116:12) }\end{array}$ \\
\hline \multirow[t]{2}{*}{ Nov. 13} & Prokeimenon & 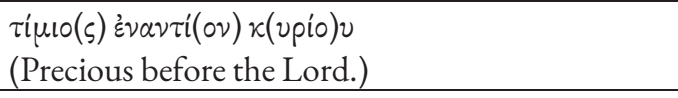 & $\begin{array}{l}\text { Ps 115:6 } \\
\text { (Ps 116:15) }\end{array}$ \\
\hline & Stichos & $\begin{array}{l}\tau^{\prime} \dot{\alpha} \nu \tau \alpha \pi \circ \delta \omega^{\prime}(\sigma \omega) \tau \tilde{\omega} \alpha\left(\nu p{ }^{\prime}\right) \omega \\
\text { (What shall I return to the Lord.) }\end{array}$ & $\begin{array}{l}\text { Ps } 115: 3 \\
\text { (Ps 116:12) }\end{array}$ \\
\hline \multirow[t]{2}{*}{ Nov. 21} & Prokeimenon & $\begin{array}{l}\mu \nu \eta \sigma \theta \eta \dot{\eta} \sigma o \mu(\alpha \iota) \tau \circ \tilde{~ o ́ v o ́} \mu \alpha \tau o(\varsigma) \\
(I \text { will remember [your] name.) }\end{array}$ & $\begin{array}{l}\text { Ps 44:18 } \\
\text { (Ps 45:17) }\end{array}$ \\
\hline & Stichos & 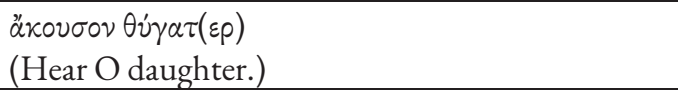 & $\begin{array}{l}\text { Ps 44:11 } \\
\text { (Ps 45:10) }\end{array}$ \\
\hline \multirow[t]{2}{*}{ Dec. 25} & Prokeimenon & 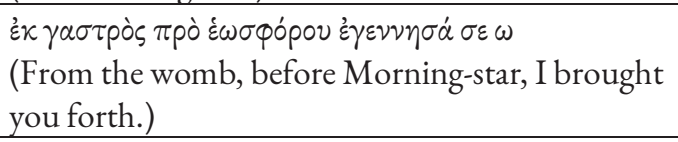 & $\begin{array}{l}\text { Ps 109:3 } \\
\text { (Ps 110:3) }\end{array}$ \\
\hline & Stichos & 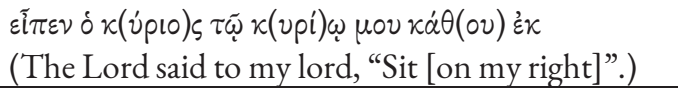 & $\begin{array}{l}\text { Ps 109:1 } \\
\text { (Ps 110:1) }\end{array}$ \\
\hline \multirow[t]{2}{*}{ Jan. 1} & Prokeimenon & 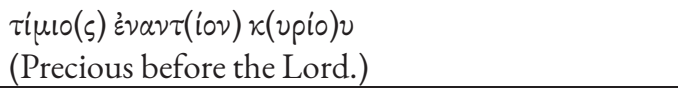 & $\begin{array}{l}\text { Ps } 115: 6 \\
\text { (Ps 116:15) }\end{array}$ \\
\hline & Stichos & $\begin{array}{l}\tau i \dot{\alpha} \nu \tau \alpha \pi \circ \delta(\dot{\omega} \sigma \omega) \\
\text { (What shall I return.) }\end{array}$ & $\begin{array}{l}\text { Ps 115:3 } \\
\text { (Ps 116:12) }\end{array}$ \\
\hline
\end{tabular}




\begin{tabular}{|c|c|c|c|}
\hline \multirow[t]{2}{*}{ Jan. 6} & Prokeimenon & 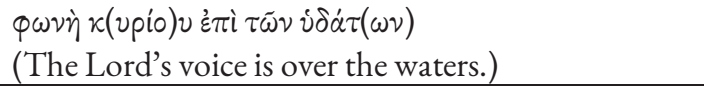 & $\begin{array}{l}\text { Ps } 28: 3 \\
\text { (Ps 29:3) }\end{array}$ \\
\hline & Stichos & 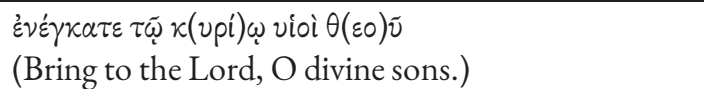 & $\begin{array}{l}\text { Ps 28:1 } \\
\text { (Ps 29:1) }\end{array}$ \\
\hline \multirow[t]{2}{*}{ Feb. 2} & Prokeimenon & 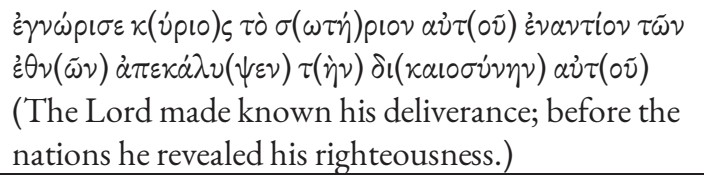 & $\begin{array}{l}\text { Ps 97:2 } \\
\text { (Ps 98:2) }\end{array}$ \\
\hline & Stichos & $\begin{array}{l}\varepsilon^{\prime \prime} \delta \circ \sigma \alpha \nu \pi \dot{\alpha} \nu \tau \alpha \tau \dot{\alpha} \pi \dot{\varepsilon} p \alpha \tau(\alpha) \tau \tilde{\eta} s \gamma(\tilde{\eta} s) \\
\text { (All the ends of the earth saw.) }\end{array}$ & $\begin{array}{l}\text { Ps } 97: 3 \\
\text { (Ps 98:3) }\end{array}$ \\
\hline \multirow[t]{2}{*}{ Mar. 25} & Prokeimenon & 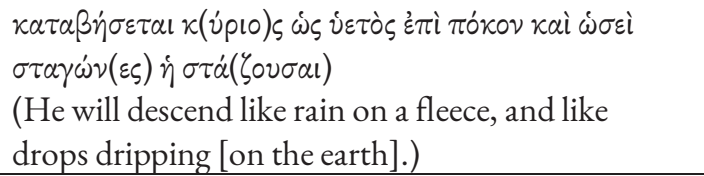 & $\begin{array}{l}\text { Ps } 71: 6 \\
\text { (Ps } 72: 6)\end{array}$ \\
\hline & Stichos & 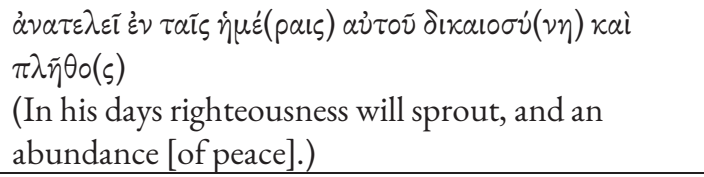 & $\begin{array}{l}\text { Ps } 71: 7 \\
\text { (Ps 72:7) }\end{array}$ \\
\hline \multirow[t]{2}{*}{ May 8} & Prokeimenon & $\begin{array}{l}\varepsilon i \zeta \pi \tilde{\alpha}(\sigma \alpha \nu) \tau(\grave{\eta} \nu) \gamma \tilde{\eta} \nu \dot{\xi} \xi \tilde{\eta} \lambda \theta(\varepsilon \nu) \\
\text { ([Their sound] went out to all the earth.) }\end{array}$ & $\begin{array}{l}\text { Ps } 18: 5 \\
\text { (Ps 19:4) }\end{array}$ \\
\hline & Stichos & $\begin{array}{l}\text { oi oủ }(\rho \alpha) \text { voi } \delta ı \gamma \gamma o \tilde{\nu} \tau(\alpha \iota) \\
\text { (The heavens are telling [of divine glory].) }\end{array}$ & $\begin{array}{l}\text { Ps } 18: 2 \\
\text { (Ps 19:1) }\end{array}$ \\
\hline \multirow[t]{2}{*}{ June 24} & Prokeimenon & 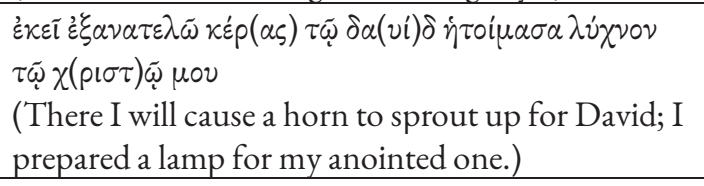 & $\begin{array}{l}\text { Ps } 131: 17 \\
\text { (Ps 132:17) }\end{array}$ \\
\hline & Stichos & 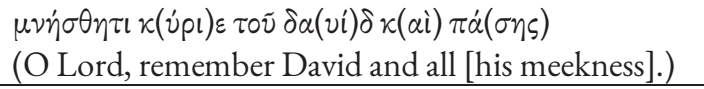 & $\begin{array}{l}\text { Ps } 131: 1 \\
\text { (Ps 132:1) }\end{array}$ \\
\hline \multirow[t]{2}{*}{ June 29} & Prokeimenon & $\begin{array}{l}\varepsilon \dot{\varepsilon} \varsigma \pi \tilde{\alpha} \sigma \alpha \nu \tau \dot{\eta} \nu \gamma \tilde{\eta} \nu \dot{\xi} \xi \tilde{\eta} \lambda \theta(\varepsilon \nu) \dot{\delta} \varphi \theta \dot{\gamma} \gamma \gamma \circ \varsigma \\
\text { (Their sound went out to all the earth.) }\end{array}$ & $\begin{array}{l}\text { Ps 18:5 } \\
(\text { Ps 19:4) }\end{array}$ \\
\hline & Stichos & 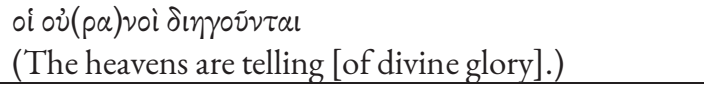 & $\begin{array}{l}\text { Ps } 18: 2 \\
(\text { Ps 19:1) }\end{array}$ \\
\hline \multirow[t]{2}{*}{ Aug. 6} & Prokeimenon & 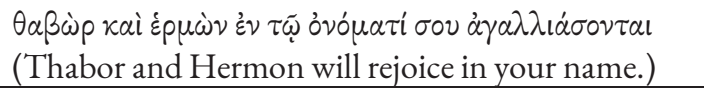 & $\begin{array}{l}\text { Ps } 88: 13 \\
\text { (Ps 89:12) }\end{array}$ \\
\hline & Stichos & 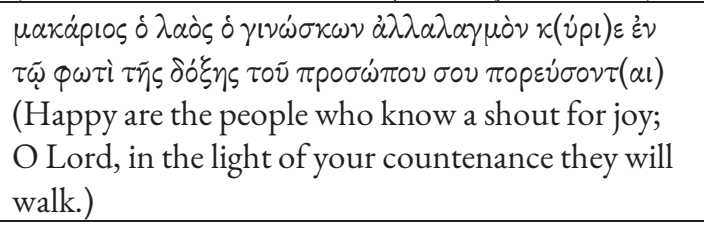 & $\begin{array}{l}\text { Ps } 88: 16 \\
\text { (Ps 89:15) }\end{array}$ \\
\hline \multirow[t]{2}{*}{ Aug. 15} & Prokeimenon & $\begin{array}{l}\mu \nu \eta \sigma \theta \dot{\eta} \sigma o \mu(\alpha \iota) \tau \circ \tilde{~ o ́} \nu o ́ \mu(\alpha \tau \circ \varsigma) \\
\text { (I will remember your name.) }\end{array}$ & $\begin{array}{l}\text { Ps 44:18 } \\
\text { (Ps 45:17) }\end{array}$ \\
\hline & Stichos & 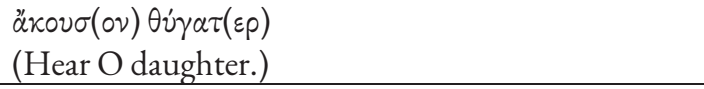 & $\begin{array}{l}\text { Ps 44:11 } \\
\text { (Ps 45:10) }\end{array}$ \\
\hline
\end{tabular}




\begin{tabular}{|c|c|c|c|}
\hline \multirow[t]{2}{*}{ Aug. 29} & Prokeimenon & $\begin{array}{l}\tau i \mu 10 \varsigma^{\prime} \varepsilon v \alpha \nu \tau i o v \kappa(\nu p i o) v \delta \theta \dot{\alpha} \nu \alpha \tau(o s) \\
\text { (Precious before the Lord is the death [of his } \\
\text { devout ones].) }\end{array}$ & $\begin{array}{l}\text { Ps 115:6 } \\
\text { (Ps 116:15) }\end{array}$ \\
\hline & Stichos & $\begin{array}{l}\tau^{\prime} \dot{\alpha} \nu \tau \alpha \pi \tau \circ \delta \omega^{\prime}(\sigma \omega) \tau \tilde{\omega} \kappa\left(\nu p i^{\prime}\right) \omega \\
\text { (What shall I return to the Lord.) }\end{array}$ & $\begin{array}{l}\text { Ps } 115: 3 \\
\text { (Ps 116:12) }\end{array}$ \\
\hline
\end{tabular}

Table 9.3: Prokeimena and stichoi texts from Psalms in the Menologion of L299.

There are nineteen examples of prokeimena and stichoi in the Menologion of Codex Zacynthius. Lowden suggests that these commemorations are for feasts with higher status in the calendar, possibly when the Patriarch himself read the Gospel in Constantinople. ${ }^{33}$ All but three lections in Codex Zacynthius have instructions to sing in the fourth tone $\left(\tilde{\eta} \chi 0 \varsigma \delta^{\prime}\right)$ : September 14th lacks any tonal instructions; August 15th indicates a nonspecific plagal tone; August 29th the grave (barys) tone. The addition of these rubrics is a key link to the Constantinopolitan rite. A comparison with the Jaharis Lectionary, an illuminated Patriarchal lectionary known to have been produced in Constantinople, shows a very close relationship in the application of these rubrics. The Jaharis Lectionary lacks the expected rubrics for January 25, Gregory the Theologian, and February 24, the discovery of the head of John the Baptist. For both of these lections, Zacynthius has a Matins reading and a Liturgy reading, but likewise no prokeimenon or stichos. Of the seventeen lections listed as having special status with prokeimena and stichoi by Lowden, all are present in Codex Zacynthius. ${ }^{34}$ The Psalm references are also remarkably close, including agreeing with the Jaharis Lectionary against the text published by Mateos. ${ }^{35}$ The only exception is August 15th, where Jaharis has Luke 1:46 and 1:48 but Zacynthius contains text from Psalm 44 which corresponds to 'another prokeimenon' at this point in the Jaharis Lectionary.

In addition, however, a prokemeinon and stichos occur in Codex Zacynthius on four further days when they would not normally be expected. These days are:

- November 1 (Cosmas and Damian)

- November 10 (Neilos)

- January 1 (Circumcision of Christ and Basil the Great)

- May 8 (John the Theologian, apostle and evangelist).

Given that it is likely that these rubrics add status to a particular commemoration, these days are unusual and may shed light on the provenance of the manuscript or, if not the place of production, its intended recipient. We will return to these commemorations.

\section{References to Constantinople and Patriarchs}

The rite of Constantinople was far reaching in the Byzantine period, so we would expect to see many references to the city in a Menologion from this period. However, the sum of Constantinople references in Zacynthius is significant. Table 9.4 contains the notable

\footnotetext{
${ }^{33}$ Lowden, The Jaharis Gospel Lectionary, 37.

${ }^{34}$ Lowden, The Jaharis Gospel Lectionary, 37, Table 6.

${ }^{35}$ Lowden, The Jaharis Gospel Lectionary, 120, referring to Juan Mateos, Le Typicon de la Grande Eglise (Rome: Edizioni Orientalia Christiana, 1962-3).
} 
Constantinopolitan references and their day of commemoration, and also references considered key by Lowden to categorise his illuminated Patriarchal manuscripts.

\begin{tabular}{|c|c|}
\hline Date & Commemoration \\
\hline Sept. 1 & $\begin{array}{l}\text { Service in the church of the Theotokos Chalkoprateion and after in the } \\
\text { great Church. The Great Fire of Constantinople in } 465 \mathrm{AD} \text {. }\end{array}$ \\
\hline Sept. 11 & $\begin{array}{l}\text { Dedication of the Church of Christ's Resurrection in Jerusalem (The Holy } \\
\text { Sepulchre). This commemoration is found in the patriarchal lectionaries. }\end{array}$ \\
\hline Sept. 14 & Sixth Church Synod. \\
\hline Sept. 21 & $\begin{array}{l}\text { The Church of the Theotokos in Petra, part of the Patriarchate of } \\
\text { Constantinople. }\end{array}$ \\
\hline Sept. 25 & Processional liturgy of the Kampos. \\
\hline Oct. 11 & $\begin{array}{l}\text { Seventh Church Synod. Generally held on Oct. 12; L299 is ambiguous } \\
\text { regarding the commemoration date. }\end{array}$ \\
\hline Oct. 22 & Abercius, Bishop of Hierapolis. The Patriarchate dedicated a chapel to him. \\
\hline Oct. 26 & The great earthquake of $740 \mathrm{AD}$ in Constantinople. \\
\hline Nov. 1 & Cosmas and Damian. Relics held in Constantinople. \\
\hline Nov. 6 & $\begin{array}{l}\text { Service in the Great Church and procession in memory of the ashes (rain of } \\
\text { cinders). }\end{array}$ \\
\hline Nov. 10 & Neilos. Prefect of Constantinople, before becoming a monk of Sinai. \\
\hline Dec. 22 & Opening of the Great Church. \\
\hline Dec. 23 & Dedication of the Great Church. \\
\hline Jan. 1 & Basil the Great. Trained at Constantinople. \\
\hline Jan. 9 & The great earthquake of $869 \mathrm{AD}$ in Constantinople. \\
\hline Jan. 12 & $\begin{array}{l}\text { Stephen Abbot of Khenolakkos Monastery, Chalcedon (often } \\
\text { remembered on Jan. 14). Geographically opposite Constantinople. }\end{array}$ \\
\hline Jan. 27 & Translation of the relics of John Chrysostom to Constantinople. \\
\hline Feb. 22 & $\begin{array}{l}\text { Uncovering of the relics of the Holy Martyrs at the Gate of Eugenius at } \\
\text { Constantinople. }\end{array}$ \\
\hline Mar. 13 & Translation of the relics of Nicephorus to Constantinople. \\
\hline Mar. 15 & John of Rouphinianai, a Monastery in Constantinople. \\
\hline May 1 & Dedication of the New Imperial Church (in $881 \mathrm{AD}$ ). \\
\hline May 11 & Birthday of Constantinople. \\
\hline June 5 & $\begin{array}{l}\text { Procession of the Kampos. Defeat of the Barbarians. Church of Saint } \\
\text { Babylas. }\end{array}$ \\
\hline July 2 & Deposition of the robe of the Theotokos at Blachernae, Constantinople. \\
\hline July 15 & Fourth and Fifth Church Synods. \\
\hline Aug. 31 & Deposition of the Holy Girdle of the Theotokos (at Chalkoprateion). \\
\hline
\end{tabular}

Table 9.4: Notable Constantinople references in the Menologion of Lectionary 299. 
Of the twenty-five references given in Lowden as significant, Zacynthius has fourteen, plus extra mentions of Constantinople in other commemorations. ${ }^{36}$ It lacks the longer Taxis and Akolouthia of September 1, but does make reference to the procession. Zacynthius is certainly not grand enough to be one of the Patriarchal lectionaries, but the exemplar may have had additional rubrics reflecting this origin. Many of the references to Constantinople in Table 9.4 are a normal part of the Menologion for Byzantine manuscripts. However, the combination of so many references is striking. Each day has a selection of possible dedications and accompanying texts, and to see so many based around Constantinople raises questions regarding the exemplar.

A great number of Patriarchs is found throughout the Menologion in Zacynthius. Table 9.5 lists the commemorations of Patriarchs, providing a further link to Constantinople.

\begin{tabular}{|c|c|c|c|}
\hline $\begin{array}{l}\text { Commemor- } \\
\text { ation date }\end{array}$ & Patriarch & $\begin{array}{l}\text { Reign } \\
\text { Dates }^{37}\end{array}$ & Title in L299 \\
\hline Sept. 2 & John the Faster (IV, Nesteutes) & $582-595$ & Patriarch \\
\hline Sept. 2 & Paul the Younger (III) & $688-94$ & Patriarch \\
\hline Oct. 11 & Nectarius & $381-97$ & Patriarch \\
\hline Oct. 11 & Arsacius & $404-5$ & Patriarch \\
\hline Oct. 11 & Atticus & $406-25$ & Patriarch \\
\hline Oct. 11 & Sisinnius (I) & $426-27$ & Patriarch \\
\hline Oct. 23 & Ignatius & $\begin{array}{l}847-58 \\
867-77\end{array}$ & Patriarch \\
\hline Nov. 6 & Paul the Confessor (I) & $\begin{array}{l}337-339, \\
341-2,346- \\
51\end{array}$ & Saint \\
\hline Nov. 13 & John Chrysostom & $398-404$ & Saint, Archbishop \\
\hline Nov. 20 & Proclus & $434-46$ & Patriarch \\
\hline Nov. 20 & Maximianus (Maximian) & $431-34$ & Patriarch \\
\hline Nov. 20 & Anatolius & $449-58$ & Patriarch \\
\hline Nov. 20 & Gennadius (I) & $458-71$ & Patriarch \\
\hline Jan. 25 & $\begin{array}{l}\text { Gregory the Theologian (I, } \\
\text { Nazianzos) }\end{array}$ & $379-81$ & Saint \\
\hline Jan. 27 & John Chrysostom (relics) & $398-404$ & Saint \\
\hline Feb. 12 & Meletius of Antioch & - & $\begin{array}{l}\text { Patriarch (normally } \\
\text { considered a Bishop) }\end{array}$ \\
\hline Feb. 12 & Anthony (II) & $893-901$ & Patriarch \\
\hline Feb. 18 & Flavian & $447-49$ & Saint \\
\hline Feb. 22 & Thomas (II) & $667-69$ & Patriarch \\
\hline Feb. 25 & Tarasius & $784-806$ & Archbishop \\
\hline
\end{tabular}

\footnotetext{
${ }^{36}$ Lowden, The Jaharis Gospel Lectionary, 32-4, Table 4.

37 Reign dates taken from 'Bishops/Patriarchs of Constantinople', Fordham University, https://sourcebooks.fordham.edu/byzantium/texts/byzpatcp.asp.
} 


\begin{tabular}{|l|l|l|l|}
\hline Mar. 13 & Nicephorus (I) (relics) & $806-15$ & Holy \\
\hline Mar. 22 & Thomas (I) & $607-10$ & Bishop \\
\hline Apr. 6 & Eutychius & $552-65$ & Archbishop \\
\hline May 12 & Germanus (I) & $715-30$ & Saint \\
\hline May 31 & Eustathius & $1019-25$ & Patriarch \\
\hline June 2 & Nicephorus (I) & $806-15$ & Archbishop \\
\hline June 4 & Metrophanes (I) & $306-314$ & Saint, Archbishop \\
\hline June 14 & Methodius (I) & $843-47$ & Archbishop \\
\hline Aug. 25 & Epiphanius & $520-35$ & Patriarch \\
\hline Aug. 25 & Menas & $536-52$ & Patriarch \\
\hline Aug. 25 & John (II, Kappadokos) & $518-20$ & Patriarch \\
\hline Aug. 30 & Alexander & $314-337$ & Patriarch \\
\hline Aug. 30 & John the Younger (III, Scholastikos) & $565-77$ & Patriarch \\
\hline (Aug. 30) & $\begin{array}{l}\text { (Paul IV may be referenced as 'and } \\
\text { the rest') }\end{array}$ & $(780-84)$ & (Patriarch) \\
\hline
\end{tabular}

Table 9.5: List of Patriarchs of Constantinople included in the Menologion of L299.

The Zacynthius lectionary is missing some of the Patriarchs regularly listed in the Menologion:

I. Cyriacus II, 596-606.

2. Nicholas II, 984-95.

3. Polyeuctus, 956-970.

4. Photius, $858-86$.

5. Sergius II, IOOI-19.

6. Nicholas I, 90I-25.

7. Stephen I, 886-93.

8. Stephen II, 925-28.

9. Euthymius I, 907-I2.

At first glance, this could be assumed to reflect the later dates of most of these Patriarchs. However, Zacynthius does include Anthony II (893-901) on February 12 and Eustathius (1019-25) on May 31, so the date appears not to be significant. Of the forty-two patriarchs listed by Lowden, Jaharis has thirty-six; Zacynthius has thirty-two, four fewer than the Patriarchal lectionary, but still a significant number. ${ }^{38}$ Zacynthius continues with its space saving techniques even here, simplifying the lists by grouping the Patriarchs. This is why it is unclear whether Paul IV is intended in the reference 'and the rest' on August 30. Such grouping of companions can also be seen in the New York Cruciform Lectionary. ${ }^{39}$

The description of the titles of the Patriarchs is also interesting. Those reigning before $451 \mathrm{AD}$ were designated as 'Archbishop', while the title 'Patriarch' came into effect for

\footnotetext{
${ }^{38}$ Lowden, The Jaharis Gospel Lectionary, Table 5 on 34-5. The figure 32 for L299 does not include Paul IV as his name is not definitively given, nor Bishop Meletius.

${ }^{39}$ Anderson, The New York Cruciform Lectionary, 69.
} 
Constantinople after the Council of Chalcedon. The commemorations in Zacynthius broadly support this traditional practice. Meletius of Antioch (Feb. 12) is listed as a Patriarch, even though tradition normally places him as a bishop. Tarasius (Feb. 25), although Patriarch was a layman at the time, and the title given by Zacynthius perhaps reflects this. The title bishop for Thomas I is harder to explain. Could the ' $\alpha p \chi$ ' of the exemplar have been overlooked in some way, demoting Thomas from Archbishop to Bishop?

Nelson, after Dolezal, identified an additional feature which ties the Patriarchal

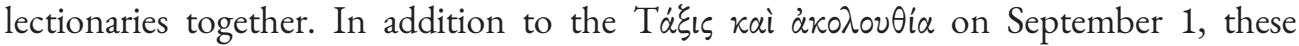
lectionaries commonly include a second reading for the fourth Sunday in Luke with additional rubrics concerning a church synod..$^{40}$ The appearance of this second lection is thus a strong pointer to a text influenced by a Constantinopolitan exemplar. The Zacynthius lectionary does not contain the double reading for the fourth Sunday in Luke. Of the fourteen entries listed as specific to Hagia Sophia by Nelson, Zacynthius includes nine. Nelson writes that 'most Byzantine lectionaries were thought to follow the rite of Constantinople no matter where they were made and examples can be deduced of provincial manuscripts with rubrics detailing processions in the capital'. ${ }^{41}$ The Zacynthius lectionary thus appears to be one of those provincial manuscripts. Indeed, the same lection that proves pivotal for Constantinopolitan affiliation may be used to demonstrate the rural production of Zacynthius: the fourth Sunday reading in Luke in this manuscript

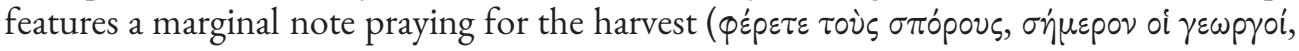
'Bring the harvest today, farmers': see Image 9.9, folio 65r top margin).

As mentioned above, the lections of Cosmas and Damian (Nov. 1), Neilos (Nov. 10), the Circumcision of Christ and Basil the Great (Jan. 1), and John the Theologian (May 8) are unexpectedly highlighted. A link to Constantinople for these lections with additional rubrics may be posited in several cases. Cosmas and Damian had their relics brought to Constantinople by the Emperor Justinian, with a basilica erected in their honour. Saint Neilos is usually celebrated on November 12, but in several manuscripts directly associated with Constantinople that date becomes November 10: before he became a monk of Sinai, Neilos was prefect of Constantinople. Basil the Great is considered the father of Eastern monasticism, and he also trained in Constantinople. Specific links between Constantinople and the Circumcision of Christ (although this is undoubtedly a major feast) and John the Theologian are more difficult to establish. It is possible that these are in some way connected with the provenance of Codex Zacynthius.

\section{THE SCRIBE OF THE LECTIONARY AND HIS MARgINAL NOTES}

Despite the absence of a colophon, it has been possible to identify the scribe of this lectionary during the course of the Codex Zacynthius Project thanks to the expertise of our colleague Georgi Parpulov. Fourteen notes in the manuscript, as part of a series of comments added by the scribe, mention the name Neilos. Some of these are markers of

\footnotetext{
${ }^{40}$ Robert S. Nelson, 'Patriarchal Lectionaries of Constantinople', in The New Testament in Byzantium (ed. D. Krueger, and R.S. Nelson. Washington DC: Dumbarton Oaks, 2016), 87-115, esp. 91.

${ }^{41}$ Nelson, 'Patriarchal Lectionaries of Constantinople,' 89.
} 
conventional piety such as 'Glory to God' and injunctions for priests to remember Neilos during an all-night vigil, but others are more unusual. The notes are written in a dodecasyllabic format, as was common at the time, in both red and black ink. What is unusual about the scribal practice in this manuscript, and the others copied by Neilos which are listed below, is that such notes appear not simply at the beginning and end of the text, but throughout the document. Table 9.6 contains a transcription and translation of the marginal notes written by the first hand. Those in bold feature the name Neilos.

\begin{tabular}{|c|c|c|}
\hline Folio & Text & Translation \\
\hline $1 \mathrm{r}$ & 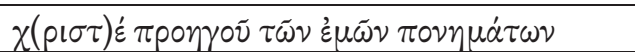 & Christ, guide my works. \\
\hline $5 r$ & 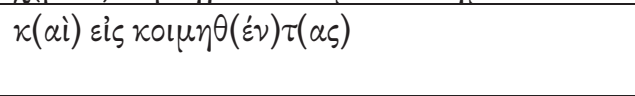 & $\begin{array}{l}\text { And for those who have fallen } \\
\text { asleep. }\end{array}$ \\
\hline $5 r$ & 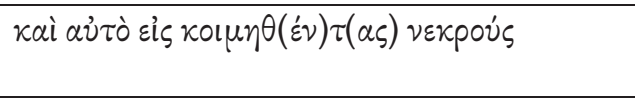 & $\begin{array}{l}\text { And the same for the dead who } \\
\text { have fallen asleep. }\end{array}$ \\
\hline $7 v$ & 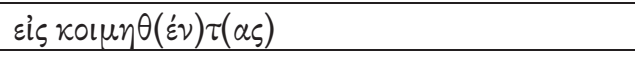 & For those who have fallen asleep. \\
\hline $8 \mathrm{r}$ & $\nu \varepsilon ́ \kappa \rho \omega \mu(\alpha)$ & For the lifeless. \\
\hline 9r & 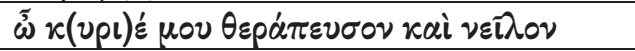 & O my Lord, heal also Neilos. \\
\hline 11r & 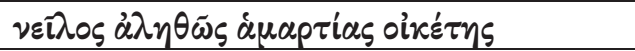 & Neilos is truly a slave to sin. \\
\hline $16 \mathrm{v}$ & 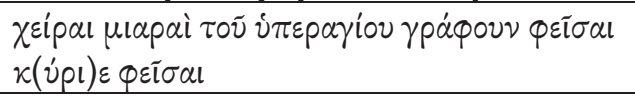 & $\begin{array}{l}\text { Unclean hands: spare, Lord, } \\
\text { spare this most holy writing. }\end{array}$ \\
\hline $17 \mathrm{r}$ & $\kappa(\hat{\nu} \rho \mathrm{l}) \varepsilon \dot{\varepsilon} \lambda \dot{\varepsilon}^{\prime}(\eta \sigma \circ \nu)$ & Lord have mercy. \\
\hline $24 \mathrm{v}$ & $\kappa(\dot{\rho} \rho) \varepsilon \sigma \tilde{\omega} \sigma \circ \nu \mu(\dot{\varepsilon}) \kappa \alpha \tau \dot{\alpha} \chi \alpha \dot{\rho} \rho \nu$ & Lord save me by grace. \\
\hline $27 \mathrm{v}$ & $\delta \delta^{\prime} \xi \alpha \sigma o l \kappa(v \dot{\rho} \mathrm{l}) \varepsilon$ & Glory to you Lord. \\
\hline $35 r$ & $\kappa\left(v_{\rho}^{\prime} \rho\right) \varepsilon \dot{\varepsilon} \lambda \dot{\varepsilon}^{\prime}(\eta \sigma o v)$ & Lord have mercy. \\
\hline $39 \mathrm{r}$ & 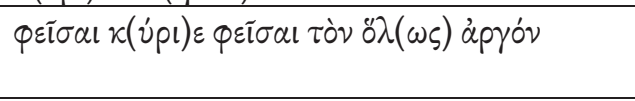 & $\begin{array}{l}\text { Spare, Lord, spare the one who is } \\
\text { completely slow. }\end{array}$ \\
\hline $40 \mathrm{r}$ & 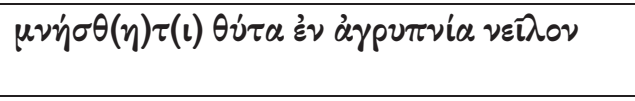 & $\begin{array}{l}\text { Priest, remember Neilos in an } \\
\text { all-night vigil. }\end{array}$ \\
\hline $43 \mathrm{v}$ & $\kappa\left(\nu_{\rho}^{\prime} \rho\right) \varepsilon \dot{\varepsilon} \lambda \dot{\varepsilon}^{\prime}(\eta \sigma o \nu)$ & Lord have mercy. \\
\hline $46 \mathrm{v}$ & $\delta^{\prime} \xi(\alpha)(\sigma o l) \kappa(v \dot{\rho} \mathrm{l}) \varepsilon$ & Glory (to you) Lord. \\
\hline $54 \mathrm{r}$ & 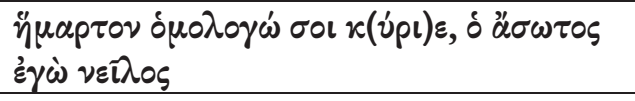 & $\begin{array}{l}\text { I confess to you Lord I have } \\
\text { sinned, I the hopeless Neilos. }\end{array}$ \\
\hline $61 \mathrm{r}$ & $\kappa(\dot{v} \rho l) \varepsilon, \tau i \zeta \delta v^{\prime} \nu \alpha \tau \alpha \iota \sigma \omega \theta \tilde{\eta} \nu \alpha l$ & Lord, who can be saved. \\
\hline 61v & 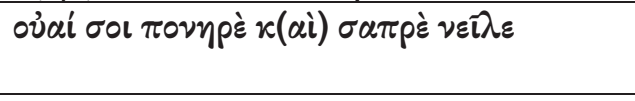 & $\begin{array}{l}\text { Woe to you worthless and evil } \\
\text { Neilos. }\end{array}$ \\
\hline $63 \mathrm{v}$ & 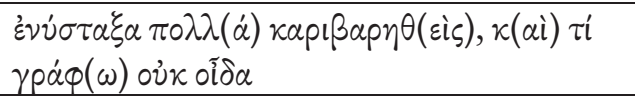 & $\begin{array}{l}\text { I am very tired with a heavy head, } \\
\text { and what I write I do not know. }\end{array}$ \\
\hline $64 \mathrm{r}$ & $\kappa(\hat{\nu} \rho) \varepsilon \varepsilon \dot{\varepsilon} \lambda \varepsilon^{\prime}(\eta \sigma o \nu)$ & Lord have mercy. \\
\hline $64 \mathrm{v}$ & $\delta^{\prime} \xi(\alpha)(\sigma \circ l) k\left(v_{\rho} \rho l\right) \varepsilon$ & Glory (to you) Lord. \\
\hline $65 r$ & 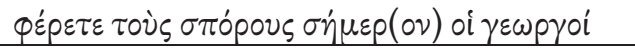 & Bring the harvest today, farmers. \\
\hline $65 \mathrm{r}$ & $\varepsilon \dot{\varepsilon} v \dot{\sigma} \sigma \alpha \zeta(\circ \nu)$ & I am tired. \\
\hline
\end{tabular}




\begin{tabular}{|c|c|c|}
\hline $70 v$ & 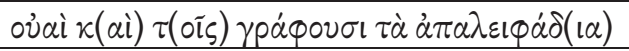 & Woe also to those writing errors. \\
\hline $72 \mathrm{v}$ & $\delta o^{\prime} \xi(\alpha)(\sigma \circ l) \kappa\left(v_{p} p l\right) \varepsilon$ & Glory (to you) Lord. \\
\hline $74 \mathrm{r}$ & 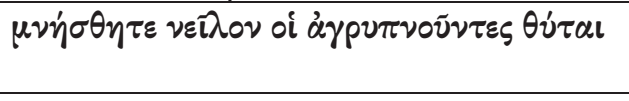 & $\begin{array}{l}\text { Priests, remember Neilos in } \\
\text { the all-night vigil. }\end{array}$ \\
\hline $76 \mathrm{v}$ & 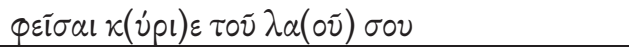 & Spare, Lord, your people. \\
\hline $77 \mathrm{r}$ & $\nu v \sigma \tau \alpha \gamma \mu(\grave{o} \varsigma) \pi \sigma \lambda \nu \grave{v}, \kappa(\alpha i) \mu \omega \rho i \alpha$ & Very drowsy and foolish. \\
\hline $78 \mathrm{r}$ & $\varepsilon i \varsigma \alpha \dot{\alpha} \pi \alpha \lambda \varepsilon ı \varphi \alpha \delta(i \alpha), \pi \dot{v} \kappa \tau \eta \varsigma^{\prime} \delta \gamma \rho \alpha \dot{\varphi} \omega \nu$ & $\begin{array}{l}\text { The one who writes tends } \\
\text { towards errors. }\end{array}$ \\
\hline $88 \mathrm{r}$ & 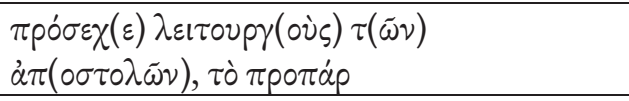 & $\begin{array}{l}\text { First of all attend to the ministers } \\
\text { of the apostles. }\end{array}$ \\
\hline $91 v$ & 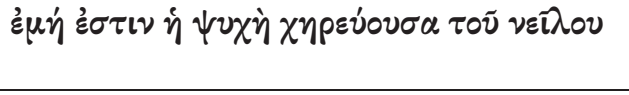 & $\begin{array}{l}\text { Mine is the soul which is } \\
\text { bereaved, of Neilos. }\end{array}$ \\
\hline $92 r$ & 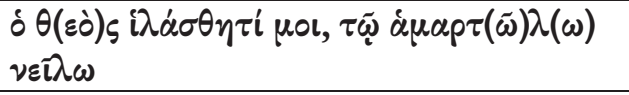 & $\begin{array}{l}\text { God be merciful to me, the } \\
\text { sinner Neilos. }\end{array}$ \\
\hline $94 r$ & 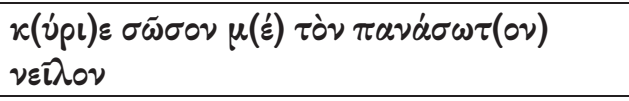 & $\begin{array}{l}\text { Lord save me, the all-hopeless } \\
\text { Neilos. }\end{array}$ \\
\hline $99 \mathrm{v}$ & 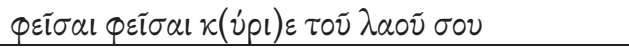 & Spare, spare Lord, your people. \\
\hline $101 \mathrm{r}$ & 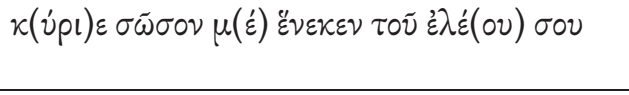 & $\begin{array}{l}\text { Lord save me on account of your } \\
\text { mercy. }\end{array}$ \\
\hline $102 \mathrm{r}$ & $\delta o^{\prime} \xi(\alpha)(\sigma \circ l) \kappa\left(v_{p} \rho l\right) \varepsilon$ & Glory (to you) Lord. \\
\hline $104 r$ & 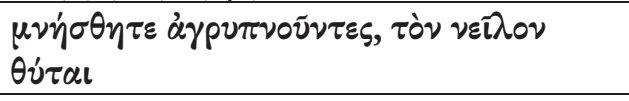 & $\begin{array}{l}\text { Priests, remember Neilos in } \\
\text { an all-night vigil. }\end{array}$ \\
\hline $104 \mathrm{v}$ & $\delta o^{\prime} \xi(\alpha)(\sigma \circ l) \kappa(\hat{v} p l) \varepsilon$ & Glory (to you) Lord. \\
\hline $106 \mathrm{v}$ & 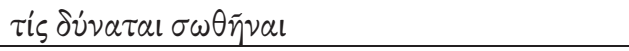 & Who can be saved? \\
\hline $108 v$ & 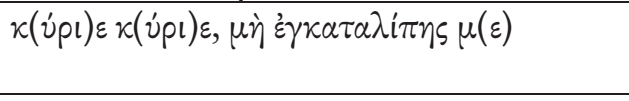 & $\begin{array}{l}\text { Lord, Lord, do not leave me } \\
\text { behind. }\end{array}$ \\
\hline $125 r$ & 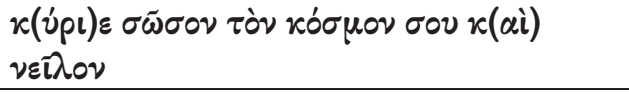 & $\begin{array}{l}\text { Lord save your world and } \\
\text { Neilos. }\end{array}$ \\
\hline $129 \mathrm{r}$ & $\kappa(\dot{v} \rho ı) \varepsilon \dot{\varepsilon} \lambda \varepsilon^{\prime}(\eta \sigma \circ \nu)$ & Lord have mercy. \\
\hline $131 \mathrm{v}$ & $\delta o^{\prime} \xi \alpha \tau \tilde{\eta} \mu \alpha x p \circ \theta \nu \mu i \alpha \sigma o v \kappa(\nu \dot{p} 1) \varepsilon$ & Glory to your patience Lord. \\
\hline $133 \mathrm{v}$ & 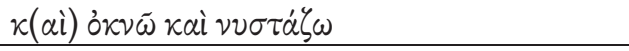 & I shun it and I am drowsy. \\
\hline 136r & 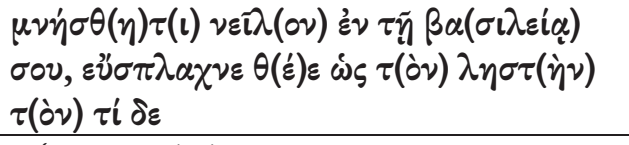 & $\begin{array}{l}\text { Remember Neilos in your } \\
\text { kingdom, merciful God, just } \\
\text { as for the robber who then ... }\end{array}$ \\
\hline $144 \mathrm{r}$ & $\delta o^{\prime} \xi \alpha \sigma o l \delta \theta(\varepsilon \dot{o}) \varsigma \pi \alpha^{\prime} \nu \tau \omega \nu \stackrel{\varepsilon}{\varepsilon} v \varepsilon \kappa \alpha$ & $\begin{array}{l}\text { Glory to you God, for the sake of } \\
\text { all. }\end{array}$ \\
\hline $144 r$ & 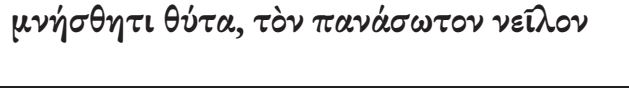 & $\begin{array}{l}\text { Remember priest, the all- } \\
\text { hopeless Neilos. }\end{array}$ \\
\hline $150 \mathrm{r}$ & 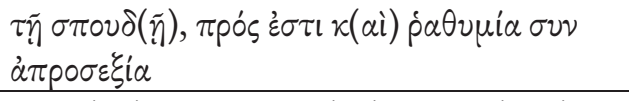 & $\begin{array}{l}\text { In haste, for laziness leads to a } \\
\text { lack of attention. }\end{array}$ \\
\hline $151 v$ & 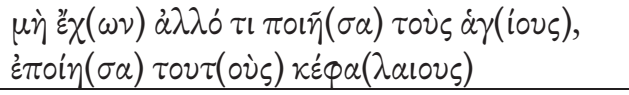 & $\begin{array}{l}\text { I have nothing else; I have done } \\
\text { the saints, I have done these great }\end{array}$ \\
\hline
\end{tabular}




\begin{tabular}{|c|c|c|}
\hline & 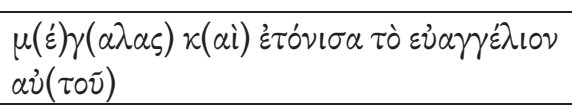 & $\begin{array}{l}\text { chapters and I have intoned his } \\
\text { gospel. }\end{array}$ \\
\hline $153 r$ & $\tau \grave{~} \sigma \phi \alpha \dot{\lambda} \mu(\alpha) \tau \circ \tilde{v} \sigma \tau \rho \alpha \beta \circ \tilde{v} \theta \varepsilon \circ \delta \dot{u}(\rho \circ v)$ & $\begin{array}{l}\text { The error of Theodore the } \\
\text { squinter. }\end{array}$ \\
\hline $157 \mathrm{r}$ & 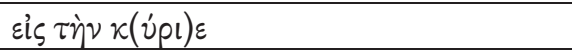 & For the Lord. \\
\hline $158 \mathrm{r}$ & $\kappa(\nu \dot{\rho} \rho) \varepsilon \dot{\varepsilon} \lambda \varepsilon^{\prime}(\eta \sigma o v)$ & Lord have mercy. \\
\hline 160r & 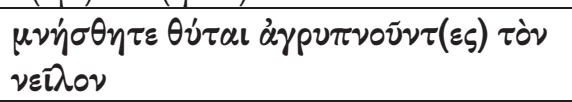 & $\begin{array}{l}\text { Priests remember Neilos in an } \\
\text { all-night vigil. }\end{array}$ \\
\hline $160 \mathrm{v}$ & $\delta \delta^{\prime} \xi(\alpha)(\sigma o l) r\left(v^{\prime} \rho l\right) \varepsilon$ & Glory (to you) Lord. \\
\hline $175 v$ & 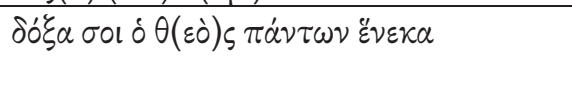 & $\begin{array}{l}\text { Glory to you God, for the sake of } \\
\text { all. }\end{array}$ \\
\hline
\end{tabular}

Table 9.6: Marginal notes by the copyist of Lectionary 299.

The note at the top of folio 1 was not originally in this position. The invocation, 'Christ guide my works', was initially written in the bottom margin of folio 1 , the same part of the page as the majority of these notes. This change in position of the prayer only became apparent on the multispectral image (Image 9.15), where the erased note may be seen in the bottom left corner, consisting of a cross followed by $\chi(\rho, \sigma \tau) \dot{\varepsilon} \pi \rho \circ(\eta \gamma \circ \tilde{)})$.

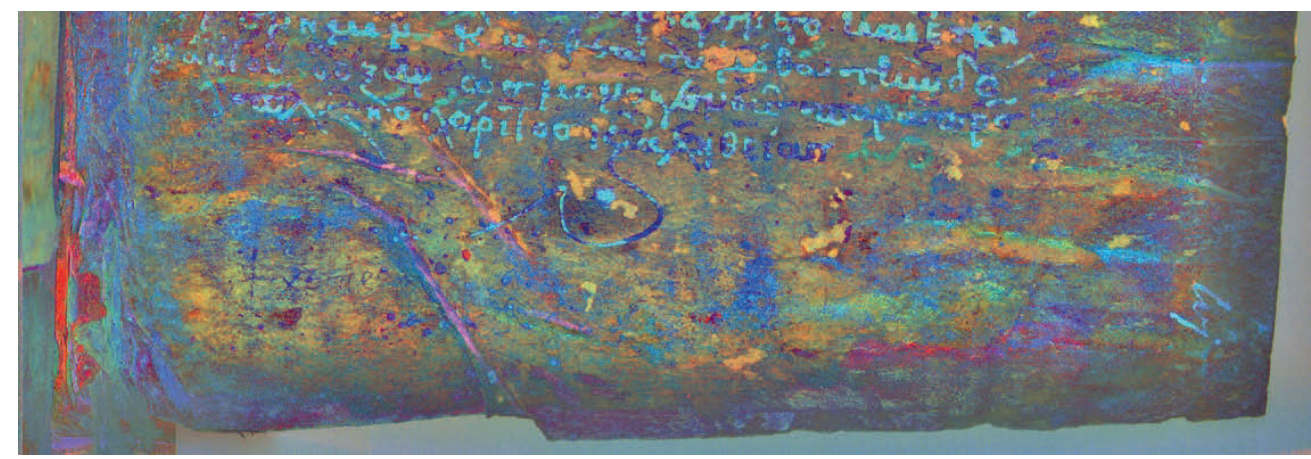

Image 9.15: Folio 1r bottom margin showing the first letters of the erased scribal note

The notes by Neilos include comments with a penitential function such as xúpı $\dot{\varepsilon} \lambda \dot{\varepsilon} \eta \sigma o \nu$ and $\delta \delta^{\prime} \xi \alpha$ кن́pı. These, along with the appeals to priests to remember the scribe in prayer, call to mind the purpose of the lectionary and its use in the Divine Liturgy. KavrusHoffmann suggests that monks copying manuscripts for their own monasteries would have wished to add their names in hope of salvation, while lay scribes who were paid for their work may not have felt the same compulsion. ${ }^{42}$ Neilos has added his name many times, describing himself as all-hopeless, evil and worthless (e.g. Image 9.16).

\footnotetext{
${ }^{42}$ Nadezhda Kavrus-Hoffmann, 'Producing New Testament Manuscripts in Byzantium,' in The New Testament in Byzantium (ed. D. Krueger, and R.S. Nelson. Washington DC: Dumbarton Oaks, 2016), 117-45, esp. 136.
} 


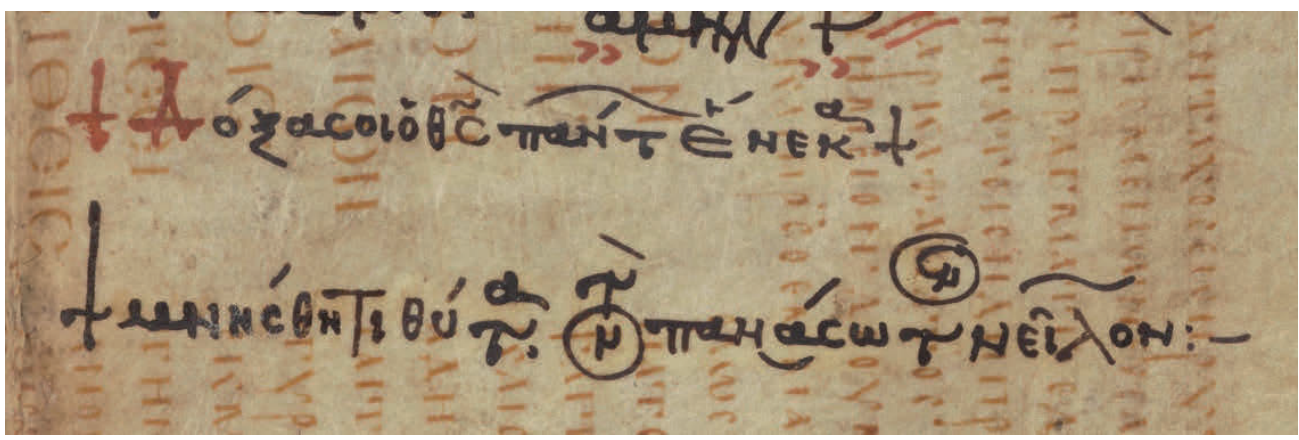

Image 9.16: Folio 144r. Two scribal notes by Neilos

Some of the marginal notes are intriguing for the light they shed on the process of book production. Errors in copying are mentioned on folia 70v, 78r and 150r: the last of these, referring to a lack of attention, follows a section of text which is particularly poorly penned. The note on folio 39r, 'Lord, spare the one who is completely slow', presumably refers to the copyist. On folio $153 \mathrm{r}$, a page full of copying errors, the bottom margin contains the words 'the error of Theodore the squinter'. Might this have been a monk having difficulty when reading the exemplar aloud to the copyist? The note on folio $151 \mathrm{v}$ seems to reflect the monotony of 'doing the saints' and 'the great chapters' of the Menologion lists. Its reference to 'intoning the gospel' could be taken literally as making the text known, but also more technically as adding the neumes. Many of the references to tiredness also occur on pages with errors or poor handwriting, such as folio $65 \mathrm{r}$ and the unusually long erasure on folio $77 \mathrm{r}$. The most striking of these is the complaint on folio $63 \mathrm{v}$ that 'I am very tired, with a heavy head, and what I write I do not know' (Image 9.17).

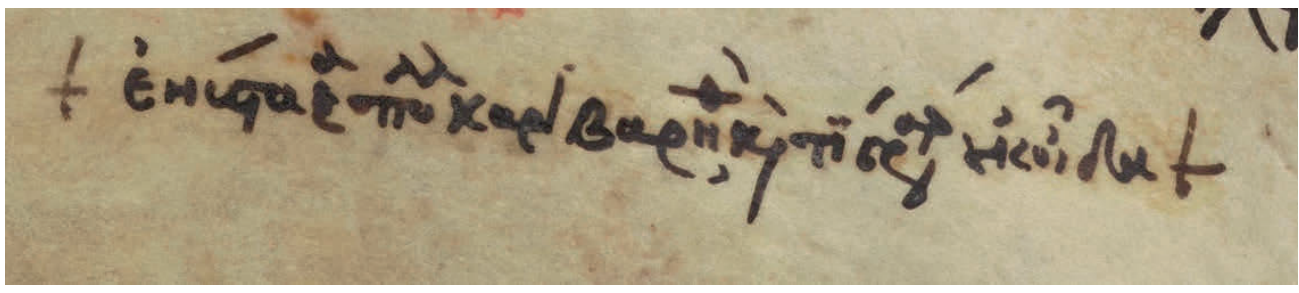

Image 9.17: Folio 63v, Note regarding tiredness

Such notes in the margins of scriptural texts may come as a surprise to modern readers. One wonders what his fellow monks or, indeed, the later users of the lectionary would have made of them. Even at the distance of several centuries, however, they bring to life the copyist of this lectionary as he comments on the challenges he faced in producing this book and reflects on his position in the grand scheme of things.

Parpulov has identified Neilos as the scribe who copied two manuscripts for the Monastery of Patmos whilst on the island of Rhodes, based on palaeographical 
comparison with the images available in Kominis' Facsimiles of Dated Patmian Codices. ${ }^{43}$ Patmos MS 175 was copied by Neilos in the year $1180 \mathrm{AD}$, the date being given in a note at the bottom of folio $72 \mathrm{v}$. The handwriting is an excellent match, and the identification is further confirmed by dodecasyllabic notes featuring the name Neilos. Patmos MS 743 was also copied by Neilos in the same year, with multiple notes throughout bearing the scribe's name. Neilos added a note in another Greek lectionary which is still in Rhodes, GA L2084. ${ }^{44}$ This manuscript is in the Church of the Holy Cross in Apollona, with no shelfmark. Although the main text of L2084 is not by Neilos, the note-dated 1181 ADis typical of his style. However, while there are also notes featuring the name Neilos in the twelfth-century Lectionary 515 (Messina, Biblioteca Universitaria, 73), the handwriting is different. Given how few scribes have the habit of adding such copious marginalia, one wonders whether a manuscript copied by the same Neilos may have served as the exemplar for this lectionary.

Wilson has added a further manuscript copied by Neilos to this list. ${ }^{45}$ Vatican, BAV, Vat. gr. 788, part A, is a Pentecostarion written by Neilos. It features an additional

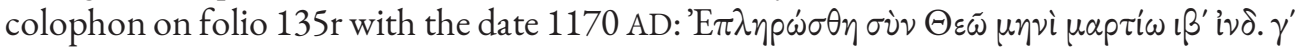

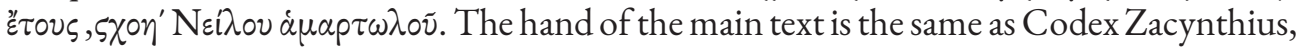
the decorative text separators are identical (cf. fol. 16r), and dodecasyllabic notes typical

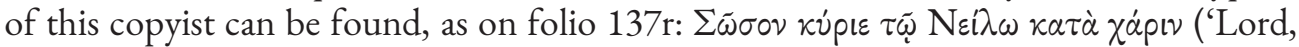
save Neilos according to grace'). The second part of this manuscript (Vaticanus graecus $788 \mathrm{~B}$ ) is not by Neilos but is overwritten in a hand of the fourteenth century; although it is a double palimpsest, we do not have here more of the catena undertext of Codex Zacynthius.

A Neilos who may plausibly be identified with this scribe was Abbot of the Monastery of John the Theologian on Rhodes. This monastery, commonly known by the name of the mountain on which it sits, Artamiti, still exists today and refers to Neilos in its history, dating his abbacy as beginning in $1174 \mathrm{AD} .{ }^{46}$ The current buildings are all from the nineteenth century, but the location of the monastery has remained unchanged for a millennium. The scribe Neilos is mentioned in Vogel and Gardthausen's Die griechischen

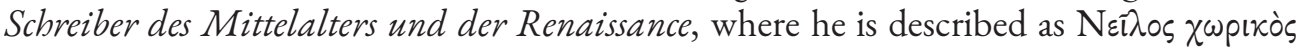

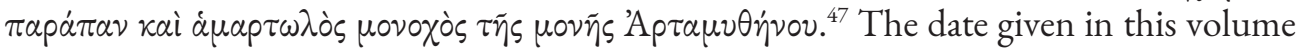

${ }^{43}$ A.D. Kominis, D.A. Zakythenos and M. Naoumides, Facsimiles of Dated Patmian Codices, (Athens: Royal Hellenic Research Foundation, Center of Byzantine Studies, 1970), Plates 16 and 17 ; see 26-7.

${ }^{44}$ Pace Kominis et al., Facsimiles, 27.

${ }^{45}$ See page 18 above.

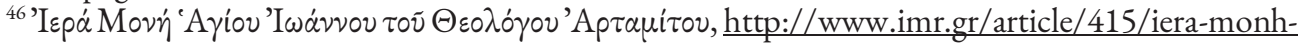
artamitoy.

${ }^{47}$ M. Vogel and V. Gardthausen, Die griechischen Schreiber des Mittelalters und der Renaissance (Leipzig: Otto Harrassowitz, 1909), 326, especially footnote 3 for the common name of the Monastery. 
of $1174 \mathrm{AD}$, repeated in Pinakes, seems to be a misunderstanding of the colophon in Patmos MS 175 which places the manuscript in the year $5 \chi \pi \eta$ (6688, equating to 1180 $\mathrm{AD})$. The latter date is assigned by Kominis and the Ghent University Database of Byzantine Book Epigrams. ${ }^{48}$

It is impossible to tell whether Codex Zacynthius was also copied for the monastery on Patmos, but the scribe can at least be identified as a monk active in the late twelfth century on Rhodes. Equally, while we cannot be certain that this lectionary was penned in the same location, it seems likely that, as abbot, Neilos would have been in a good position to produce such a manuscript as this, especially considering his apparent access to other codices. Although the population of this time was highly mobile, the balance of probability is that Neilos was attached to this monastery for some time, and that Codex Zacynthius too may thus be linked with Rhodes.

Returning to the lections where the additional prokeimena and stichoi seemed unusual, it is now possible to observe that the lections which did not fit well with Constantinople may actually point towards an immediate provenance of the manuscript in Rhodes. The highlighting of John the Theologian gains significance in the light of the dedication of the Artemiti monastery on Rhodes to John the Theologian, who is also the patron saint of the monastery on Patmos for which Neilos copied at least two manuscripts. Similarly, the indication of Neilos on November 10 may be an instance of Neilos the scribe honouring his namesake. The selection of readings for which prokeimena and stichoi are provided may thus be seen as providing information relating both to the exemplar and to the setting of the production of this manuscript. This shows both the reach of the influence of Constantinople and also the subtle ways a scribe could influence a text to give status to matters he considered of importance.

Two further observations may be made in the light of the identification of the scribe and the date at which the lectionary was copied. The presence of colophons ending the other manuscripts written by Neilos strengthens the suggestion made on page 171 above that the Resurrection readings may originally have been present at the end of the manuscript on pages which had fallen out prior to its rebinding. In addition, it is striking that the date at which Neilos was active is very close to that at which the other manuscript with the same type of catena as Codex Zacynthius was copied: the colophon to Paris, Bibliothèque nationale de France, suppl. gr. 612 indicates that it was written in 1164. Its writing is in the epsilon style used at the time in Cyprus. ${ }^{49}$ Might the exemplar of this manuscript have been produced contemporaneously with Codex Zacynthius, with both copies of the catena reaching the end of their useful life at around the same time? The fact

48 The Ghent University Database of Byzantine Book Epigrams is available online at https://www.dbbe.ugent.be.

${ }^{49}$ Paul Canart, 'Les écritures livresques chypriotes du milieu du XIe siècle au milieu du XIIIe et le style palestino-chypriote 'epsilon',' Scrittura e Civiltà 5 (1981): 17-76; Paul Canart and L. Perria, 'Les écritures livresques des XI et XII siècles,' in Paleografia e codicologia greca. Atti del II Colloquio internazionale Berlino-Wolfenbüttel, 17-20 ottobre 1983, ed. D. Harlfinger and G. Prato (Alessandria: Edizioni dell'Orso, 1991), 67-116, especially 91. 
that the the gospel text of the Paris manuscript is unrelated to that of Codex Zacynthius, along with the differences in attribution of some of the scholia as discussed in Chapter 8, means that-even if the intention had been to reproduce the older manuscript for ongoing use-one would have to posit an updating of the text being copied..$^{50}$ While this similarity may be entirely coincidental, given the rarity of this type of catena these documents have the potential at least to provide information about the length of time that manuscripts were in use in the mediaeval period.

\section{CORRECTIONS}

Despite the impression given by some of his self-deprecating notes, Neilos the scribe actually made very few errors in writing this codex. A quick look at any page will not reveal many corrections or erasures; the electronic transcription produced by the Codex Zacynthius Project, consisting of well over 90,000 words, has just 290 corrections. Most of these are orthographic changes, often involving vowel shifts, which were often corrected by the main scribe during the process of copying. A few of these change the meaning of the text, such as $\chi \varepsilon i \rho \omega \nu$ ('worse') for $\chi \eta \dot{p} \omega \nu$ ('widows') in Matthew 23:14 (fol. $114 \mathrm{v})$. Given that the text would have been read aloud, however, the identical pronunciation of these vowels would have made no difference in sense to the hearers of the gospel. Very few corrections are long additions or deletions. Corrections of particular interest are mentioned below, with * being the first hand, $\mathrm{C}$ being the corrector, om. for omission and del. for deletion.

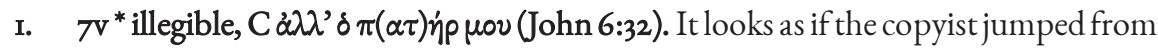
one ovjpavov to the next, writing $\tau \dot{\partial} v \dot{\alpha} \lambda \eta \theta$ ivóv, then realised his mistake so erased the text and rewrote $\dot{\alpha} \lambda \lambda{ }^{\prime} \delta \pi(\alpha \tau) \dot{\eta} \rho \mu \nu v$. We cannot be certain of the first hand text because the erasure was thorough.

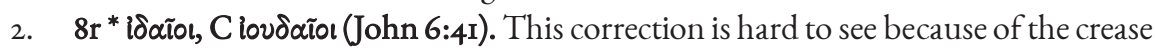
in the page. It is slightly offset to the left of the expected place, but the intention is clear.

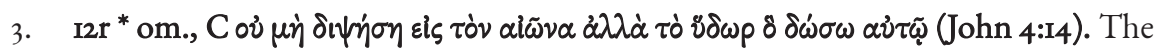
scribe's eye jumped from one $\delta \delta \dot{\omega} \sigma \omega \alpha \dot{\tau} \tau \tilde{\omega}$ to the next, so this text was added in the margin using a decorative caret $(※)$. The neumes were added to the correction, indicating the presence of the correction before the ekphonetic notation was added.

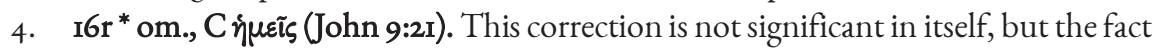
that it is added using red ink suggests it was noticed during the addition of the red ekphonetic notation. The caret is unusual for this manuscript, being $\mathrm{x}$-shaped.

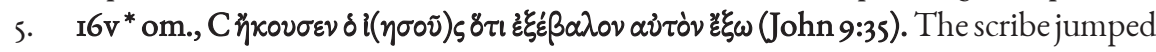
between the two instances of $\ddot{\xi} \xi \omega$, omitting the phrase which was later added in the

\footnotetext{
${ }^{50}$ According to the grouping of the Text und Textwert method, the Paris manuscript agrees with the Majority Text in $94.4 \%$ of the test passages, and the manuscripts to which it is closest are 344 12811417152023622396 2442, agreeing with them at 100\%. See http://intf.unimuenster.de/TT_PP/Cluster4.php.
} 
left margin. Of more interest is that this correction does not appear to be made by Neilos. The hand is lighter, has a subtle slope to the right, and uses an unusual shape caret to mark the text (a circle with a conical shape attached to the top right).

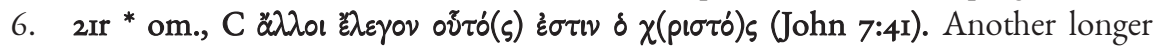
omission caused by the scribe jumping between two similar words, with the correction text added in the margin and marked by a caret $(※)$.

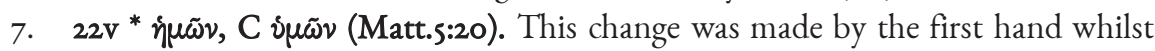
writing. Changes between these two words are particularly prevalent in this lectionary.

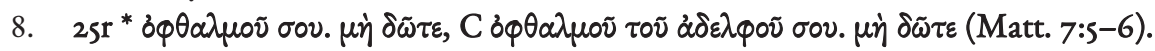
The correction affects the last words of verse 5 , where the scribe omitted 'the brother'. However, to erase enough text to fit this in, the start of the next verse ended up being rewritten in the margin. This shows that the correction was not made whilst the scribe was writing, thus demonstrating later correction of the text, whether by the main scribe or someone else.

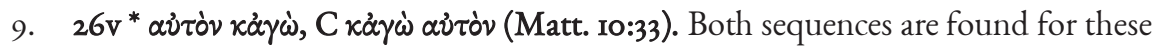
words in the textual tradition, but the method in which they are reordered here is interesting. The copyist writes numerals above the words, $\beta$ then $\alpha$, in order to transpose them. These transposition marks can also be seen on folio $72 \mathrm{~V}$.

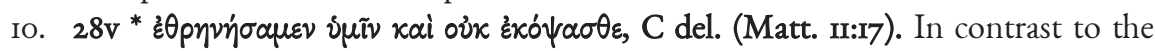
omissions, here Neilos wrote the same phrase twice. The first instance was thoroughly erased, leaving almost an entire line blank in the codex which is striking to the eye.

II. $28 \mathrm{v}^{*} \pi \dot{\alpha} \sigma \alpha \mathrm{l}, \mathrm{C} \pi \dot{\alpha} \lambda \alpha \mathbf{l}$ (Matt. Ir:2I). The correction by the scribe as he wrote is only of one letter, yet it changes the meaning from 'all' to 'long ago'.

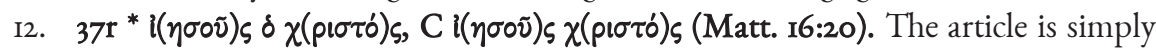
deleted by a stroke. Usually the addition or deletion of the title Jesus is what distinguishes the text, not the addition or deletion of the article.

13. 42r * $\delta \delta \delta \rho \alpha \gamma \mu \alpha, C \delta \delta \delta \rho \alpha \chi \mu \alpha$ (Matt. 17:24). A simple correction by the first hand, adding the correct letter above the one to be replaced. This also serves as a reminder that orthographic changes can be of similar-sounding consonants as well as vowels.

I4. $\mathbf{4 2 v}^{*} \varepsilon \dot{\varepsilon}, \mathrm{C}$ o $\mathfrak{u}_{x}$ (Matt. 17:2I). Correction by erasure and overwriting. This is probably done by a later hand, although it is hard to be sure because parchment which is made rough through erasure takes the ink differently.

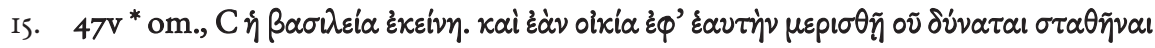
(Mark 3:24-25). Another longer marginal correction by the original scribe, marked with a caret $(※)$ and caused by jumping from one $\sigma \tau \alpha \theta \tilde{\eta} v \alpha$ l to the next. Neilos definitely checked his own work.

16. 5or ${ }^{*}+, \mathrm{C}$ del. (Mark 5:I2). This is an unusual correction because it is not of the main text but of the ekphonetic notation. The red cross after $\varepsilon i \sigma \varepsilon \dot{\varepsilon} \lambda \omega \omega \mu \varepsilon \nu$ has been erased by means of a dot in black ink placed above it. This shows that a level of correction happened after the ekphonetic notation was added, which included checking the neumes. 
17. $56 \mathrm{r}^{*} \mathrm{om} ., \mathrm{C} \tau \dot{\mathrm{o}}$ (Mark 8:Io). This small addition was made by the main scribe above the line of text where it was missing.

I8. 63V * $\tau \tilde{\eta} \delta^{\prime} \tau \tilde{\eta} \varsigma \delta^{\prime} \varepsilon \beta \delta o \mu \alpha \dot{\delta} \delta \varsigma \mathrm{C} \tau \tilde{\eta} \gamma^{\prime} \tau \tilde{\eta} \varsigma \delta^{\prime} \varepsilon \beta \delta o \mu \alpha \dot{\delta} 0 \varsigma$ (pre-Luke 8:I). This is an example of a correction to the paratext. The lection heading number is corrected in matching red ink, on the page where Neilos wrote a note stating that he was tired.

19. 65r. The bottom of this page contains a great number of corrections of minor errors (see Image 9.9). We find five errors in the start of the lection on this page, along with a note referring to tiredness at the bottom. A similar situation can be seen at the bottom of folio 77r, with multiple corrections in a short space, and one long erasure at the end of the page when text was repeated over the folio break. Again, this was marked with a note for tiredness.

20. $67 \mathrm{v}^{*}$ om., C of $\pi \varepsilon \mu \varphi \theta \varepsilon \dot{v} \tau \varepsilon \varsigma$ (Luke 7:10). The omission of these words is understandable as the sentence will function without them. However, to find them

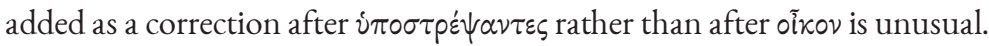

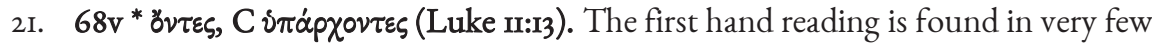
manuscripts, among which is the fourth-century Codex Sinaiticus. The correction is significant only in that a cross-shaped caret is used $(+)$ rather than the usual cross with four dots $(※)$. This may suggest a separate corrector working here, or that Neilos used multiple forms of caret symbol.

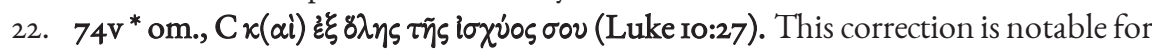
being written in black ink, yet marked by a red caret by the marginal correction, and two corresponding red carets in the text to indicate the addition. It seems the corrector returned to this correction with a different pen in his hand, or had both inks readily available for use.

23. $77 \mathrm{v}^{*}$ yàp, C del. (Luke 18:I7). Deleted using red ink, presumably during the addition of the neumes or lection headings.

24. $78 \mathrm{r}^{*}$ om., C Elxov (Luke 19:20). A simple addition, but noticeable as the missing word was added both above the text, as expected, and then again in the right margin, presumably for clarity.

25. 82r * axpı, C axpıs av (Luke 21:24). A simple correction, selected as this was penned by a later hand, showing continued use of the manuscript.

26. 9ir * om., C $\alpha \dot{\tau} \tau \dot{\tau} \varsigma$ y $\dot{\alpha} \rho \delta \alpha(v i) \delta$ (Mark I2:36). Again, this may be a secondary hand correcting, using a cross shape (+) for a caret. It is hard to be definite as the hand of the main text is untidy at this point.

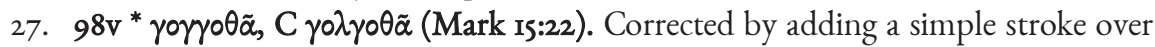
the gamma, this remains an unusual mistake with a well-known place name.

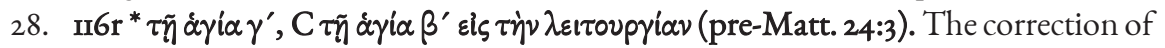
this heading is complex. It seems originally the lection was assigned to be read during Wednesday liturgy, then changed to be read during Tuesday liturgy. It follows Wednesday Matins which begins on folio II3v, so the Wednesday liturgy reading was expected. (A Tuesday liturgy reading was already cross-referenced on folio II3r.) To complicate matters further, underneath part of the final rubrics are 
the words in black $\dot{\alpha} \pi \dot{o} \delta \varepsilon \tilde{\pi} \tau \nu$ v, showing that the position of this reading had already been altered to Compline. Additional rubrics were then added at the end of Matt. 24:35 to mark the end of the additional Tuesday liturgy reading (fol. II7r), before the Wednesday liturgy reading is referenced on folio II7r beginning at Matt. 24:36. This may be evidence for different calendars of readings being incorporated into the one lectionary.

29. Ir8v. A long addition by the original scribe at the bottom of the page is erased and rewritten in the margin. The reasons for this are unclear.

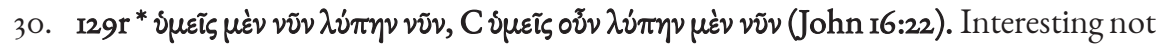
for the text, but for the method. The change of position of $\mu \dot{\varepsilon} \nu$ is made using red

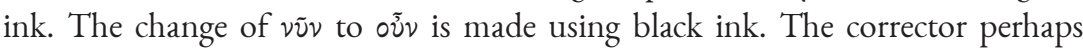
returned to this correction when he was holding a different pen.

3I. $\quad$ I47 $\mathbf{V}^{*}$ om., C $\delta \dot{\varepsilon}$ (John 19:16). Another addition above the line using red ink. See also folio I5ov, the addition of $x(v \dot{p}) \varepsilon$.

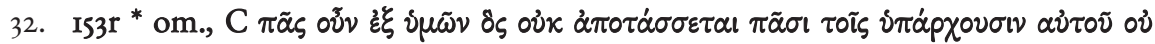

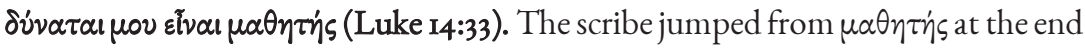
of $\mathrm{I} 4: 27$ to $\mu \alpha \theta \eta \tau \eta^{\prime} s$ at the end of $\mathrm{I} 4: 33$. This may suggest copying from a lectionary: in a continuous-text manuscript this would be a lengthy oversight, whereas in the context of this lection it is simply a difference of a single verse.

33. I7Iv * $\mu^{\alpha}$ átupos, C lepoúáptupos (July 6th heading). The martyr Aetios is 'promoted' to the title of Hieromartyr with this addition squeezed over the text.

This selection of corrections shows the complexity of the lectionary. Some corrections were completed by the main scribe whilst he wrote. Others were added by the main scribe both before the ekphonetic notation, and also after. We also see evidence of other hands working on the text. We find corrections in both black and red ink, suggesting that some corrections were made during the addition of the red ekphonetic notation. However, as the addition of the red enlarged letters to start each lection seems to have been made at the same time as the writing of the main text, it is likely that Neilos had both black and red ink available to use on his desk, so the colour is not an indicator of correction order. Indeed, Anderson suggests that it was common medieval practice to have both inks available, as witnessed by author portraits using both inks. ${ }^{51}$ This would explain the correction of black text using red ink, and of red neumes using black ink.

The mistakes are of the usual sort seen in any New Testament manuscript: orthographic variations, repeated words and phrases, and omitted words and phrases. There are also different types of carets being used to mark marginal additions. Standard techniques for correction are employed: erasure and rewriting, adding text above the line, marginal additions, overdots and strike-throughs to delete small amounts of text, and transposition marks. The paratext and even the neumes were corrected. Some corrections were rewritten in the margin for clarity, suggesting this was a working text which needed to be read aloud. The correction of lection order on folio 116r is significant, showing different traditions of readings.

\footnotetext{
${ }^{51}$ Anderson, The New York Cruciform Lectionary, 31.
} 
As noted with regard to the correction on folio $153 \mathrm{r}$, it is likely that the exemplar for Lectionary 299 was another lectionary. This contrasts with the conclusions of recent scholarship that lectionaries were copied from continuous text manuscripts. ${ }^{52}$ Further evidence for a lectionary source can be seen in the incorrect gospel attributions, which would be less likely when a continuous-text exemplar was used. One of these, Mark instead of Matthew on November $29^{\text {th }}$, is shared with the Jaharis Gospel lectionary, but this is a one-off and cannot be used as evidence for a particular connection between these two documents. In addition, there are cross-references referring forwards in the codex to lections not yet written, and cross-references to other cross-references, when the actual reading could just as easily have been written if the manuscript was being compiled from a continuous-text manuscript using lection tables. The best explanation is that these were simply copied from a previous lectionary without checking. Furthermore, the notes which mark the ends of lections which were not even mentioned in the place where they belong could hint at different strands of tradition being incorporated into this one lectionary. Nothing can be certain until a full study of the text has been undertaken and compared with many other lectionaries, but for now it may be said that the text behind the lectionary of Codex Zacynthius may have a complicated history.

\section{OTHER INDICATIONS OF LATER USE}

In addition to the corrections made by later hands, there are four marginal notes which are not the work of Neilos. These are presented in Table 9.7:

\begin{tabular}{|c|c|c|}
\hline Folio & Text & Translation \\
\hline $51 \mathrm{r}$ & $\kappa \alpha \theta \eta \gamma \eta \tau \dot{s} s \delta \chi\left(\rho ı \sigma \sigma^{\prime}\right) \varsigma$ & Christ the instructor \\
\hline $90 \mathrm{v}$ & 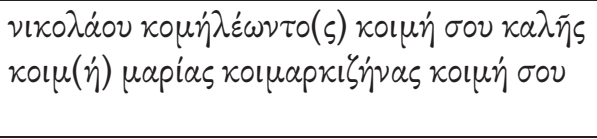 & $\begin{array}{l}\text { Your sleeping, Nicholas } \\
\text { Komeleon, a fine sleeping, your } \\
\text { sleeping Maria Kymarkizinas }\end{array}$ \\
\hline $120 \mathrm{v}$ & Kalpos & Time \\
\hline $130 \mathrm{v}$ & $\begin{array}{l}\mu \nu \eta^{\prime}(\sigma) \theta(\eta) \tau(\iota) \text { oi íp(oi) } \\
\kappa \omega(\nu \sigma \tau \alpha \nu \tau \iota \nu \circ \nu) \pi\left(o^{\prime} \lambda \varepsilon \omega \varsigma\right)\end{array}$ & $\begin{array}{l}\text { Remember, priests of } \\
\text { Constantinople }\end{array}$ \\
\hline
\end{tabular}

Table 9.7: Marginal notes by later hands in Lectionary 299.

On folio 51r, a later user of the codex has repeated the last words of a lection at the bottom of the page, from Matthew 23:10. The same hand also added some letters in the left margin of the previous page from the word $\sigma x v \lambda \lambda \lambda \varepsilon$ s. Neither of these additions appears to be significant. The names on folio 90v, apparently in memory of two of the faithful departed, may be interpreted in a number of ways. The word for time, kaipos, is scribbled at an odd angle on $120 \mathrm{v}$, and on folio $130 \mathrm{v}$ there is an injunction to priests. These later notes have

\footnotetext{
${ }^{52}$ For Apostolos manuscripts, see Gibson, The Apostolos, 229. For Gospel manuscripts, see Jordan, 'The Textual Tradition of the Gospel of John,' 522, although he does also discuss copying from lectionaries on 511-12.
} 
little bearing on the provenance of the manuscript and simply reflect the continued use of the lectionary. There are also indecipherable scribbles on folia 10r, 40v and 55r. Whether this was simply cleaning a pen nib, or random marks from a later user, is unclear. On the inside back cover of the manuscript, written directly onto the wooden board, there

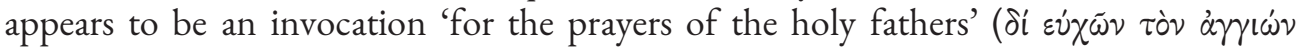
$\pi[\alpha \tau \dot{\varepsilon} \rho] \omega[\nu]$ - sic). This is written twice, once with a thinner nib: although the letter shapes resemble those of the first hand, the spelling errors suggest that this is the work of a later imitator. Gibson suggests that the wear and tear lectionaries received in continual use means they were frequently replaced. This particular manuscript, however, seems to have been in constant use for several centuries, judging by the date of the supplemental leaf and the rebinding and repairs to the cover.

\section{CONCLUSION}

The Greek New Testament lectionary tradition remains an underexplored field. Even so, the detailed examination of this one manuscript has resulted in a surprising amount of information about its history, structure, production, copyist and use. We have been able to establish with a reasonable degree of confidence that it was probably written at the very end of the twelfth century on the island of Rhodes by a scribe and monk named Neilos. Not only did he add notes of conventional piety in the margin, but he also upbraided himself and perhaps also his fellow monks for errors during the production process. $\mathrm{He}$ may even have been responsible for giving special prominence to the feast of his namesake, in addition to the commemoration of the patron of his monastery. The influence of the Constantinople rite is strong in this lectionary, especially when compared to other Constantinopolitan lectionaries like the Jaharis Gospel lectionary and the New York Cruciform lectionary. The exemplar for Codex Zacynthius seems to have itself been a lectionary, perhaps from Constantinople: this would explain the large number of specific references to this city, its commemorations and patriarchs. However, as many lectionaries were influenced by the rite of Constantinople, it is hard to judge how many of these features would be considered 'normal' in a monastery on Rhodes.

The lectionary consists of two parts, the Synaxarion followed by the Menologion. The Resurrection readings are not extant, but may well have formed part of the original production. The manuscript was not written as a display book but as a working text, with the copyist adding ekphonetic notation and other rubricated elements. At the same time, it is a highly compressed text, for use by experienced liturgists. Might this also reflect a shortage of writing material which led to the palimpsesting of an earlier document which had reached the end of its useful life? At any rate, this lectionary appears to have served its purpose in the Divine Liturgy for several centuries, and was repaired and treasured for many more years beyond that. Even in the nineteenth century it was a valuable gift from a distinguished antiquarian to a representative of a foreign society for the promotion of the study and use of the Bible. The latest stage in its history, in the form of digital images and complete electronic text, means that it is now available for study and examination on a broader scale than has ever before been possible. This introduction is only the beginning of the new life of this fascinating document, a testament to many generations of tradition, 
preservation, and use, not forgetting the key figure of the tired copyist Neilos, who did not do as bad a job of producing this lectionary as he thought. 


\section{LIST: CONTENTS OF THE LECTIONARY}

The original version of this list was produced by W.J. Elliott for the International Greek New Testament Project and subsequently updated by Rachel Kevern before being used by the Codex Zacynthius Project. It is divided into two sections:

1. The Synaxarion: Readings are identified by 'S' for 'Synaxarion', 'W' for 'Week' and 'D' for 'Day'

2. The Menologion: Readings are identified by ' $M$ ' and 'D' for 'Month' and 'Day'

The Synaxarion is divided into five periods:

i. Pascha to Pentecost: S1 W1 D1 - S1 W8 D1

ii. Pentecost to the Elevation of the Cross: S2 W1 D2 - S2 W18 D2

iii. Elevation of the Cross to Lent: S3 W1 D2 - S3 W20 D1

iv. Lent to Holy Week: S4 W1 D2 - S4 W7 D1b

v. Holy Week: S5 W1 D2a - S5 W1 D7b

The Menologion calendar begins with September, so M1 is September, M2 October etc. The Resurrection readings are identified by ' $\mathrm{R}$ '. These are missing from L299, but are cross-referenced.

Days with multiple readings are numbered $a, b$, etc.

The folio where the lection begins is listed for reference.

\section{The Synaxarion}

\begin{tabular}{|l|l|l|l|}
\hline Day & Text (written) & Folio & Cross-reference text to locate and read \\
\hline S1W1D1a & John 1:1-17 & $1 \mathrm{r}$ & \\
\hline S1W1D1b & - & - & $\begin{array}{l}\text { Read S1W2D1, John 20:19-25 (Only the } \\
\text { end of the lection is marked in the } \\
\text { manuscript.) }\end{array}$ \\
\hline S1W1D2 & John 1:18-28 & $1 \mathrm{v}$ & \\
\hline S1W1D3 & Luke 24:12 & $1 \mathrm{v}$ & Read R5, Luke 24:12-25 (missing) \\
\hline S1W1D4 & John 1:35-51 & $2 \mathrm{r}$ & \\
\hline S1W1D5 & John 3:1-15 & $2 \mathrm{v}$ & \\
\hline S1W1D6 & John 2:12-22 & $3 \mathrm{r}$ & \\
\hline S1W1D7 & John 3:22-33 & $3 \mathrm{v}$ & \\
\hline S1W2D1 & John 20:19-31 & $3 \mathrm{v}$ & \\
\hline S1W2D2 & John 2:1-11 & $4 \mathrm{v}$ & \\
\hline S1W2D3 & John 3:16-21 & $4 \mathrm{v}$ & \\
\hline S1W2D4 & John 5:17-24 & 5r & \\
\hline S1W2D5 & John 5:24-30 & $5 \mathrm{r}$ & \\
\hline S1W2D6 & John 5:30-6:2 & $5 \mathrm{v}$ & \\
\hline S1W2D7 & John 6:14-27 & $6 \mathrm{r}$ & \\
\hline S1W3D1 & Mark 15:43-16:8 & $6 \mathrm{v}$ & $\begin{array}{l}\text { (R2 is marked in the margin for Mark } \\
16: 1-8 .)\end{array}$ \\
\hline & & & \\
\hline
\end{tabular}




\begin{tabular}{|c|c|c|c|}
\hline Day & Text (written) & Folio & Cross-reference text to locate and read \\
\hline S1W3D2 & John 4:46-54 & $7 \mathrm{r}$ & \\
\hline S1W3D3 & John 6:27-33 & $7 \mathrm{v}$ & \\
\hline S1W3D4 & John 6:35-39 & $7 \mathrm{v}$ & \\
\hline S1W3D5 & John 6:40-44 & $8 \mathrm{r}$ & \\
\hline S1W3D6 & John 6:48-54 & $8 \mathrm{r}$ & \\
\hline S1W3D7 & John 15:17-16:2 & $8 \mathrm{v}$ & \\
\hline S1W4D1 & John 5:1-15 & $9 \mathrm{r}$ & \\
\hline S1W4D2 & John 6:56-69 & $9 \mathrm{v}$ & \\
\hline S1W4D3 & John $7: 1-13$ & $9 \mathrm{v}$ & \\
\hline S1W4D4 & John 7:14-30 & $10 \mathrm{r}$ & \\
\hline S1W4D5 & John 8:12-20 & $10 \mathrm{v}$ & \\
\hline S1W4D6 & John 8:21-30 & $11 \mathrm{r}$ & \\
\hline S1W4D7 & John $8: 31-42$ & $11 \mathrm{r}$ & \\
\hline S1W5D1 & John $4: 5-42$ & $11 \mathrm{v}$ & \\
\hline S1W5D2 & John $8: 42-51$ & $13 r$ & \\
\hline S1W5D3 & John 8:51-59 & $13 \mathrm{v}$ & \\
\hline S1W5D4 & John 6:5-14 & $13 \mathrm{v}$ & \\
\hline S1W5D5 & John 9:39-10:9 & $14 \mathrm{r}$ & \\
\hline S1W5D6 & John 10:17-28 & $14 \mathrm{v}$ & \\
\hline S1W5D7 & John $10: 27-38$ & $15 \mathrm{r}$ & \\
\hline S1W6D1 & John 9:1-38 & $15 \mathrm{r}$ & \\
\hline S1W6D2 & John 11:47-54 & $16 \mathrm{v}$ & \\
\hline S1W6D3 & John 12:19-36 & $17 \mathrm{r}$ & \\
\hline S1W6D4 & John $12: 36-47$ & $17 \mathrm{v}$ & \\
\hline S1W6D5a & Mark 16:9 & $17 \mathrm{v}$ & Read R3, Mark 16:9-20 (missing) \\
\hline S1W6D5b & Luke 24:36 & $18 \mathrm{r}$ & Read R6, Luke 24:36-53 (missing) \\
\hline S1W6D6 & John 14:1-11 & $18 \mathrm{r}$ & \\
\hline S1W6D7 & John 14:10-21 & $18 \mathrm{r}$ & \\
\hline S1W7D1 & John $17: 1-13$ & $18 \mathrm{v}$ & \\
\hline S1W7D2 & John 14:27-15:7 & $19 \mathrm{r}$ & \\
\hline S1W7D3 & John $16: 2-13$ & $19 \mathrm{v}$ & \\
\hline S1W7D4 & John $16: 15-23$ & $20 \mathrm{r}$ & \\
\hline S1W7D5 & John $16: 23-33$ & $20 \mathrm{r}$ & \\
\hline S1W7D6 & John $17: 18-26$ & $20 \mathrm{v}$ & \\
\hline S1W7D7 & - & $21 \mathrm{r}$ & Read R11, John 21:14-25 (missing) \\
\hline S1W8D1a & John 20:19 & $21 \mathrm{r}$ & $\begin{array}{l}\text { No instructions; expected text John 20:19- } \\
23\end{array}$ \\
\hline S1W8D1b & John $7: 37-52 ; 8: 12$ & $21 \mathrm{r}$ & \\
\hline S2W1D2 & Matt. 18:10-20 & $21 \mathrm{v}$ & \\
\hline S2W1D3 & Matt. 4:23-5:13 & $22 \mathrm{r}$ & \\
\hline
\end{tabular}




\begin{tabular}{|c|c|c|c|}
\hline Day & Text (written) & Folio & Cross-reference text to locate and read \\
\hline S2W1D4 & Matt. 5:20-26 & $22 \mathrm{v}$ & \\
\hline S2W1D5 & Matt. 5:27-32 & $23 r$ & \\
\hline S2W1D6 & Matt. 5:33-41 & $23 r$ & \\
\hline S2W1D7 & Matt. 5:42-48 & $23 r$ & \\
\hline S2W2D1 & $\begin{array}{l}\text { Matt. } 10: 32-33,37- \\
38 ; 19: 27-30\end{array}$ & $23 \mathrm{v}$ & \\
\hline S2W2D2 & $\begin{array}{l}\text { Matt. 6:31-34; 7:9- } \\
14\end{array}$ & $24 \mathrm{r}$ & \\
\hline S2W2D3 & Matt. 7:15-21 & $24 \mathrm{r}$ & \\
\hline S2W2D4 & Matt. 7:21-23 & $24 \mathrm{v}$ & \\
\hline S2W2D5 & Matt. 8:23-27 & $24 \mathrm{v}$ & \\
\hline S2W2D6 & Matt. 9:14-17 & $24 \mathrm{v}$ & \\
\hline S2W2D7 & Matt. 7:1-8 & $25 \mathrm{r}$ & \\
\hline S2W3D1 & Matt. 4:18-23 & $25 \mathrm{r}$ & \\
\hline S2W3D2 & Matt. 9:36-10:8 & $25 \mathrm{v}$ & \\
\hline S2W3D3 & Matt. 10:9-15 & $26 \mathrm{r}$ & \\
\hline S2W3D4 & Matt. 10:16-22 & $26 \mathrm{r}$ & \\
\hline S2W3D5 & Matt. 10:23-31 & $26 \mathrm{v}$ & \\
\hline S2W3D6 & Matt. 10:32-36; 11:1 & $26 \mathrm{v}$ & \\
\hline S2W3D7 & Matt. 7:24-8:4 & $27 \mathrm{r}$ & \\
\hline S2W4D1 & Matt. 6:22-33 & $27 \mathrm{v}$ & \\
\hline S2W4D2 & Matt. 11:2-15 & $28 \mathrm{r}$ & \\
\hline S2W4D3 & Matt. 11:16-20 & $28 \mathrm{r}$ & \\
\hline S2W4D4 & Matt. 11:20-26 & $28 \mathrm{v}$ & \\
\hline S2W4D5 & Matt. 11:27-30 & $28 \mathrm{v}$ & \\
\hline S2W4D6 & Matt. 12:1-8 & $29 \mathrm{r}$ & \\
\hline S2W4D7 & Matt. 8:14-23 & $29 r$ & \\
\hline S2W5D1 & Matt. 8:5-13 & $29 \mathrm{v}$ & \\
\hline S2W5D2 & Matt. 12:9-13 & $30 \mathrm{r}$ & \\
\hline S2W5D3 & $\begin{array}{l}\text { Matt. 12:14-16, 22- } \\
30\end{array}$ & $30 \mathrm{r}$ & \\
\hline S2W5D4 & Matt. 12:38-45 & $30 \mathrm{v}$ & \\
\hline S2W5D5 & Matt. 12:46-13:3 & $31 \mathrm{r}$ & \\
\hline S2W5D6 & Matt. 13:3-12 & $31 \mathrm{r}$ & \\
\hline S2W5D7 & Matt. 9:9-13 & $31 \mathrm{v}$ & \\
\hline S2W6D1 & Matt. 8:28-9:1 & $31 \mathrm{v}$ & \\
\hline S2W6D2 & Matt. 13:10-23 & $32 \mathrm{r}$ & \\
\hline S2W6D3 & Matt. 13:24-30 & $32 \mathrm{v}$ & \\
\hline S2W6D4 & Matt. 13:31-36 & $32 \mathrm{v}$ & \\
\hline S2W6D5 & Matt. 13:36-43 & $33 r$ & \\
\hline S2W6D6 & Matt. 13:44-54 & $33 r$ & \\
\hline S2W6D7 & Matt. 9:18-26 & $33 \mathrm{v}$ & \\
\hline
\end{tabular}




\begin{tabular}{|c|c|c|c|}
\hline Day & Text (written) & Folio & Cross-reference text to locate and read \\
\hline S2W7D1 & Matt. 9:1-8 & $34 \mathrm{r}$ & \\
\hline S2W7D2 & Matt. 13:54-58 & $34 \mathrm{r}$ & \\
\hline S2W7D3 & Matt. 14:1-13 & $34 \mathrm{v}$ & \\
\hline S2W7D4 & Matt. 14:35-15:11 & $35 \mathrm{r}$ & \\
\hline S2W7D5 & Matt. 15:12-21 & $35 \mathrm{r}$ & \\
\hline S2W7D6 & Matt. 15:29-31 & $35 \mathrm{v}$ & \\
\hline S2W7D7 & Matt. 10:37-11:1 & $35 \mathrm{v}$ & \\
\hline S2W8D1 & Matt. 9:27-35 & $36 \mathrm{r}$ & \\
\hline S2W8D2 & Matt. 16:1-6 & $36 \mathrm{v}$ & \\
\hline S2W8D3 & Matt. 16:6-12 & $36 \mathrm{v}$ & \\
\hline S2W8D4 & Matt. 16:20-24 & $37 \mathrm{r}$ & \\
\hline S2W8D5 & Matt. 16:24-28 & $37 \mathrm{r}$ & \\
\hline S2W8D6 & Matt. 17:10-18 & $37 \mathrm{r}$ & \\
\hline S2W8D7 & Matt. 12:30-37 & $37 \mathrm{v}$ & \\
\hline S2W9D1 & Matt. 14:14-22 & $37 \mathrm{v}$ & \\
\hline S2W9D2 & Matt. 18:1-11 & $38 \mathrm{r}$ & \\
\hline S2W9D3 & $\begin{array}{l}\text { Matt. 18:18-22; } \\
\text { 19:1-2, 13-15 }\end{array}$ & $38 \mathrm{v}$ & \\
\hline S2W9D4 & Matt. 20:1-16 & $39 \mathrm{r}$ & \\
\hline S2W9D5 & Matt. 20:17-28 & $39 \mathrm{v}$ & \\
\hline S2W9D6 & $\begin{array}{l}\text { Matt. 21:12-14, 17- } \\
20\end{array}$ & $39 \mathrm{v}$ & \\
\hline S2W9D7 & Matt. 15:32-39 & $40 \mathrm{r}$ & \\
\hline S2W10D1 & Matt. 14:22-34 & $40 \mathrm{v}$ & \\
\hline S2W10D2 & Matt. 21:18-22 & $40 \mathrm{v}$ & \\
\hline S2W10D3 & Matt. 21:23-27 & $41 \mathrm{r}$ & \\
\hline S2W10D4 & Matt. 21:28-32 & $41 \mathrm{r}$ & \\
\hline S2W10D5 & Matt. 21:43-46 & $41 \mathrm{v}$ & \\
\hline S2W10D6 & Matt. 22:23-33 & $41 \mathrm{v}$ & \\
\hline S2W10D7 & Matt. 17:24-18:4 & $42 r$ & \\
\hline S2W11D1 & Matt. 17:14-23 & $42 \mathrm{r}$ & \\
\hline S2W11D2 & $\begin{array}{l}\text { Matt. 23:14, 13, 15- } \\
22\end{array}$ & $42 v$ & \\
\hline S2W11D3 & Matt. 23:23-28 & $43 r$ & \\
\hline S2W11D4 & Matt. 23:29-39 & $43 r$ & \\
\hline S2W11D5 & Matt. 24:13-28 & $43 v$ & \\
\hline S2W11D6 & $\begin{array}{l}\text { Matt. 24:27-33, 42- } \\
51\end{array}$ & $44 \mathrm{r}$ & \\
\hline S2W11D7 & Matt. 19:3-12 & $44 \mathrm{v}$ & \\
\hline S2W $12 \mathrm{D} 1$ & Matt. 18:23-35 & $44 \mathrm{v}$ & \\
\hline
\end{tabular}




\begin{tabular}{|c|c|c|c|}
\hline Day & Text (written) & Folio & Cross-reference text to locate and read \\
\hline S2W $12 \mathrm{D} 2$ & Mark 1:9-15 & $45 \mathrm{r}$ & \\
\hline S2W12D3 & Mark 1:16-22 & $45 \mathrm{v}$ & \\
\hline S2W12D4 & Mark 1:23-28 & $45 \mathrm{v}$ & \\
\hline S2W12D5 & Mark 1:29-35 & $45 \mathrm{v}$ & \\
\hline S2W12D6 & Mark 2:18-22 & $46 \mathrm{r}$ & \\
\hline S2W12D7 & Matt. 20:29-34 & $46 \mathrm{r}$ & \\
\hline S2W13D1 & Matt. 19:16-26 & $46 \mathrm{v}$ & \\
\hline S2W13D2 & Mark 3:6-12 & $47 \mathrm{r}$ & \\
\hline S2W13D3 & Mark 3:13-21 & $47 \mathrm{r}$ & \\
\hline S2W $13 \mathrm{D} 4$ & Mark 3:20-27 & $47 \mathrm{v}$ & \\
\hline S2W13D5 & Mark 3:28-35 & $47 \mathrm{v}$ & \\
\hline S2W13D6 & Mark 4:1-9 & $48 \mathrm{r}$ & \\
\hline S2W13D7 & Matt. 22:15-22 & $48 \mathrm{r}$ & \\
\hline S2W14D1 & Matt. 21:33-42 & $48 \mathrm{v}$ & \\
\hline S2W14D2 & Mark 4:10-23 & $48 \mathrm{v}$ & \\
\hline S2W14D3 & Mark 4:24-34 & $49 \mathrm{r}$ & \\
\hline S2W14D4 & Mark 4:35-41 & $49 \mathrm{v}$ & \\
\hline S2W14D5 & Mark 5:1-20 & $50 \mathrm{r}$ & \\
\hline S2W $14 \mathrm{D} 6$ & $\begin{array}{l}\text { Mark 5:22-24, 35- } \\
6: 1\end{array}$ & $50 \mathrm{v}$ & \\
\hline S2W14D7 & Matt. 23:1-12 & $51 \mathrm{r}$ & \\
\hline S2W15D1 & Matt. 22:2-14 & $51 \mathrm{v}$ & \\
\hline S2W15D2 & Mark 5:24-34 & $52 \mathrm{r}$ & \\
\hline S2W15D3 & Mark 6:1-7 & $52 \mathrm{r}$ & \\
\hline S2W15D4 & Mark 6:7-13 & $52 \mathrm{v}$ & \\
\hline S2W15D5 & Mark 6:30-45 & $52 \mathrm{v}$ & \\
\hline S2W15D6 & Mark 6:45-53 & $53 \mathrm{r}$ & \\
\hline S2W15D7 & Matt. 24:1-13 & $53 \mathrm{v}$ & \\
\hline S2W16D1 & Matt. 22:35-46 & $54 \mathrm{r}$ & \\
\hline S2W16D2 & Mark 6:54-7:8 & $54 \mathrm{v}$ & \\
\hline S2W16D3 & Mark 7:5-16 & $54 \mathrm{v}$ & \\
\hline S2W16D4 & Mark 7:14-24 & $55 \mathrm{r}$ & \\
\hline S2W16D5 & Mark 7:24-30 & $55 \mathrm{v}$ & \\
\hline S2W16D6 & Mark 8:1-10 & $56 \mathrm{r}$ & \\
\hline S2W16D7 & Matt. 24:34-44 & $56 \mathrm{r}$ & \\
\hline S2W17D1 & Matt. 25:14 & $56 \mathrm{v}$ & Read S5W1D3b, Matt. 25:14-29 \\
\hline S2W17D2 & - & - & \\
\hline S2W17D3 & - & - & \\
\hline S2W17D4 & - & - & \\
\hline S2W17D5 & - & - & \\
\hline S2W17D6 & - & - & \\
\hline S2W17D7 & Matt. 25:1-13 & $56 \mathrm{v}$ & \\
\hline
\end{tabular}




\begin{tabular}{|c|c|c|c|}
\hline Day & Text (written) & Folio & Cross-reference text to locate and read \\
\hline S2W18D1 & - & - & \\
\hline S3W1D2 & Luke 3:19-22 & $57 \mathrm{r}$ & \\
\hline S3W1D3 & Luke 3:23-4:1 & $57 \mathrm{r}$ & \\
\hline S3W1D4 & Luke $4: 1-15$ & $57 \mathrm{v}$ & \\
\hline S3W1D5 & Luke 4:16-22 & $58 \mathrm{r}$ & \\
\hline S3W1D6 & Luke $4: 22-30$ & $58 \mathrm{r}$ & \\
\hline S3W1D7 & Luke 4:31-36 & $58 \mathrm{v}$ & \\
\hline S3W2D1 & Luke 5:1-11 & $58 \mathrm{v}$ & \\
\hline S3W2D2 & Luke $4: 38-44$ & $59 \mathrm{r}$ & \\
\hline S3W2D3 & Luke 5:12-16 & $59 \mathrm{v}$ & \\
\hline S3W2D4 & Luke 5:33-39 & $59 \mathrm{v}$ & \\
\hline S3W2D5 & Luke 6:12-19 & $60 \mathrm{r}$ & \\
\hline S3W2D6 & Luke 6:17-23 & $60 \mathrm{r}$ & \\
\hline S3W2D7 & Luke 5:17-26 & $60 \mathrm{v}$ & \\
\hline S3W3D1 & Luke 6:31-36 & $61 \mathrm{r}$ & \\
\hline S3W3D2 & Luke 6:24-30 & $61 \mathrm{r}$ & \\
\hline S3W3D3 & Luke 6:37-45 & $61 \mathrm{v}$ & \\
\hline S3W3D4 & Luke 6:46-7:1 & $62 \mathrm{r}$ & \\
\hline S3W3D5 & Luke $7: 17-30$ & $62 \mathrm{r}$ & \\
\hline S3W3D6 & Luke $7: 31-35$ & $62 \mathrm{v}$ & \\
\hline S3W3D7 & Luke 5:27-32 & $62 \mathrm{v}$ & \\
\hline S3W4D1 & Luke $7: 11-16$ & $63 r$ & \\
\hline S3W4D2 & Luke 7:36-50 & $63 r$ & \\
\hline S3W4D3 & Luke $8: 1-3$ & $63 \mathrm{v}$ & \\
\hline S3W4D4 & Luke 8:22-25 & $64 \mathrm{r}$ & \\
\hline S3W4D5 & Luke 9:7-11 & $64 \mathrm{r}$ & \\
\hline S3W4D6 & Luke 9:12-18 & $64 \mathrm{v}$ & \\
\hline S3W4D7 & Luke 6:1-10 & $64 \mathrm{v}$ & \\
\hline S3W5D1 & Luke $8: 5-15,8$ & $65 \mathrm{r}$ & \\
\hline S3W5D2 & Luke 9:18-22 & $65 \mathrm{v}$ & \\
\hline S3W5D3 & Luke 9:23-27 & $65 \mathrm{v}$ & \\
\hline S3W5D4 & Luke 9:44-50 & $65 \mathrm{v}$ & \\
\hline S3W5D5 & Luke 9:49-56 & $66 \mathrm{r}$ & \\
\hline S3W5D6 & Luke 10:1-15 & $66 \mathrm{v}$ & \\
\hline S3W5D7 & Luke $7: 1-10$ & $67 \mathrm{r}$ & \\
\hline S3W6D1 & Luke 16:19-31 & $67 \mathrm{v}$ & Plus extra instructions \\
\hline S3W6D2 & Luke 10:22-24 & $68 \mathrm{r}$ & \\
\hline S3W6D3 & Luke 11:1-10 & $68 \mathrm{r}$ & \\
\hline S3W6D4 & Luke 11:9-13 & $68 \mathrm{v}$ & \\
\hline S3W6D5 & Luke 11:14-23 & $68 \mathrm{v}$ & \\
\hline
\end{tabular}




\begin{tabular}{|c|c|c|c|}
\hline Day & Text (written) & Folio & Cross-reference text to locate and read \\
\hline S3W6D6 & Luke 11:23-26 & $69 \mathrm{r}$ & \\
\hline S3W6D7 & Luke 8:16-21 & $69 \mathrm{r}$ & \\
\hline S3W7D1 & Luke 8:26-35, 38-39 & $69 \mathrm{v}$ & \\
\hline S3W7D2 & Luke 11:29-33 & $70 \mathrm{r}$ & \\
\hline S3W7D3 & Luke 11:34-41 & $70 \mathrm{v}$ & \\
\hline S3W7D4 & Luke 11:42-46 & $70 \mathrm{v}$ & \\
\hline S3W7D5 & Luke 11:47-12:1 & $71 \mathrm{r}$ & \\
\hline S3W7D6 & Luke 12:2-12 & $71 \mathrm{r}$ & \\
\hline S3W7D7 & Luke 9:1-6 & $71 \mathrm{v}$ & \\
\hline S3W8D1 & Luke 8:41-56 & $71 \mathrm{v}$ & \\
\hline S3W8D2 & $\begin{array}{l}\text { Luke 12:13-15, 22- } \\
31\end{array}$ & $72 \mathrm{v}$ & \\
\hline S3W8D3 & Luke 12:42-48 & $72 \mathrm{v}$ & \\
\hline S3W8D4 & Luke 12:48-59 & $73 r$ & \\
\hline S3W8D5 & Luke 13:1-9 & $73 \mathrm{v}$ & \\
\hline S3W8D6 & Luke 13:31-35 & $73 \mathrm{v}$ & \\
\hline S3W8D7 & Luke 9:37-43 & $74 \mathrm{r}$ & \\
\hline S3W9D1 & Luke 10:25-37 & $74 \mathrm{v}$ & \\
\hline S3W9D2 & Luke $14: 1,12-15$ & $75 r$ & \\
\hline S3W9D3 & Luke 14:25-35 & $75 \mathrm{r}$ & \\
\hline S3W9D4 & Luke 15:1-10 & $75 \mathrm{v}$ & \\
\hline S3W9D5 & Luke 16:1-9 & $75 \mathrm{v}$ & \\
\hline S3W9D6 & $\begin{array}{l}\text { Luke 16:15-18, } \\
17: 1-4\end{array}$ & $76 \mathrm{r}$ & \\
\hline S3W9D7 & Luke 9:57-62 & $76 \mathrm{v}$ & \\
\hline S3W10D1 & Luke 12:16-21 & $76 \mathrm{v}$ & \\
\hline S3W10D2 & Luke 17:20-25 & $77 \mathrm{r}$ & \\
\hline S3W10D3 & Luke $17: 26-37 ; 18: 8$ & $77 \mathrm{r}$ & \\
\hline S3W10D4 & $\begin{array}{l}\text { Luke } 18: 15-17,26- \\
30\end{array}$ & $77 \mathrm{v}$ & \\
\hline S3W10D5 & Luke 18:31-34 & $77 \mathrm{v}$ & \\
\hline S3W10D6 & $\begin{array}{l}\text { Luke 19:12-28 (plus } \\
\text { Matt. 25:24 twice) }\end{array}$ & $77 \mathrm{v}$ & \\
\hline S3W10D7 & Luke 10:19-21 & $78 \mathrm{v}$ & \\
\hline S3W11D1 & Luke 13:10-17 & $78 \mathrm{v}$ & \\
\hline S3W11D2 & Luke 19:37-44 & $79 \mathrm{r}$ & \\
\hline S3W11D3 & Luke 19:45-48 & $79 \mathrm{r}$ & \\
\hline S3W11D4 & Luke 20:1-8 & $79 \mathrm{r}$ & \\
\hline S3W11D5 & Luke 20:9-18 & $79 \mathrm{v}$ & \\
\hline S3W11D6 & Luke 20:19-26 & $80 \mathrm{r}$ & \\
\hline S3W11D7 & Luke 12:32-40 & $80 \mathrm{r}$ & \\
\hline S3W12D1 & Luke 14:16-24 & $80 \mathrm{v}$ & \\
\hline
\end{tabular}




\begin{tabular}{|c|c|c|c|}
\hline Day & Text (written) & Folio & Cross-reference text to locate and read \\
\hline S3W12D2 & Luke 20:27-44 & $81 \mathrm{r}$ & \\
\hline S3W12D3 & Luke 21:12-19 & $81 \mathrm{v}$ & \\
\hline S3W12D4 & $\begin{array}{l}\text { Luke } 21: 5-8,10-11 \text {, } \\
20-24\end{array}$ & $81 \mathrm{v}$ & \\
\hline S3W12D5 & Luke 21:28-33 & $82 \mathrm{r}$ & \\
\hline S3W12D6 & Luke 21:37-22:8 & $82 \mathrm{r}$ & \\
\hline S3W12D7 & Luke 13:19-29 & $82 \mathrm{v}$ & Plus extra instructions \\
\hline S3W13D1 & Luke 17:12-19 & $83 r$ & \\
\hline S3W13D2 & Mark 8:11-21 & $83 \mathrm{r}$ & \\
\hline S3W13D3 & Mark 8:22-26 & $83 \mathrm{v}$ & \\
\hline S3W13D4 & Mark 8:30-34 & $84 \mathrm{r}$ & \\
\hline S2W13D5 & Mark 9:10-16 & $84 \mathrm{r}$ & \\
\hline S3W13D6 & Mark 9:33-41 & $84 \mathrm{v}$ & \\
\hline S3W13D7 & Luke 14:1-11 & $84 \mathrm{v}$ & \\
\hline S3W14D1 & Luke 18:18-27 & $85 \mathrm{r}$ & \\
\hline S3W14D2 & Mark 9:42-10:1 & $85 \mathrm{v}$ & \\
\hline S3W14D3 & Mark 10:2-12 & $86 \mathrm{r}$ & \\
\hline S3W14D4 & Mark 10:11-16 & $86 r$ & \\
\hline S3W14D5 & Mark 10:17-27 & $86 \mathrm{v}$ & \\
\hline S3W14D6 & Mark 10:24-32 & $87 \mathrm{r}$ & \\
\hline S3W14D7 & Luke $16: 10-15$ & $87 \mathrm{r}$ & \\
\hline S3W15D1 & Luke 18:35-43 & $87 \mathrm{v}$ & \\
\hline S3W15D2 & Mark 10:46-52 & $87 \mathrm{v}$ & \\
\hline S3W15D3 & Mark 11:11-23 & $88 \mathrm{r}$ & \\
\hline S3W15D4 & $\begin{array}{l}\text { Mark 11:23-26(plus } \\
\text { Luke 11:9-10) }\end{array}$ & $88 \mathrm{v}$ & \\
\hline S3W15D5 & Mark 11:27-33 & $88 \mathrm{v}$ & \\
\hline S3W15D6 & Mark 12:1-12 & $89 \mathrm{r}$ & \\
\hline S3W15D7 & Luke 17:3-10 & $89 \mathrm{v}$ & \\
\hline S3W16D1 & Luke 19:1-10 & $89 \mathrm{v}$ & \\
\hline S3W16D2 & Mark 12:13-17 & $90 \mathrm{r}$ & \\
\hline S3W16D3 & Mark 12:18-27 & $90 \mathrm{r}$ & \\
\hline S3W16D4 & Mark 12:28-37 & $90 \mathrm{v}$ & \\
\hline S3W16D5 & Mark 12:38-44 & $91 \mathrm{r}$ & \\
\hline S3W16D6 & Mark 13:1-8 & $91 \mathrm{r}$ & \\
\hline S3W16D7 & Luke $18: 2-8$ & $91 \mathrm{v}$ & \\
\hline S3W17D1a & Matt. 15:21-28 & $92 \mathrm{r}$ & Plus extra instructions \\
\hline S3W17D1b & Luke 18:10-14 & $92 \mathrm{r}$ & \\
\hline S3W17D2 & Mark 13:9-13 & $92 \mathrm{v}$ & \\
\hline S3W17D3 & Mark 13:14-23 & $92 v$ & \\
\hline
\end{tabular}




\begin{tabular}{|c|c|c|c|}
\hline Day & Text (written) & Folio & Cross-reference text to locate and read \\
\hline S3W17D4 & Mark 13:24-31 & $93 r$ & \\
\hline S3W17D5 & Mark 13:31-14:2 & $93 r$ & \\
\hline S3W17D6 & Mark 14:1-11 & $93 \mathrm{v}$ & \\
\hline S3W17D7 & Luke 20:46-21:4 & $94 \mathrm{r}$ & \\
\hline S3W18D1 & Luke 15:11-32 & $94 \mathrm{r}$ & \\
\hline S3W18D2 & Mark 11:1-11 & $95 \mathrm{r}$ & \\
\hline S3W18D3 & Mark 14:10-42 & $95 \mathrm{v}$ & \\
\hline S3W18D4 & Mark 14:43-15:1 & $96 \mathrm{v}$ & \\
\hline S3W18D5 & Mark 15:1-15 & $98 \mathrm{r}$ & \\
\hline S3W18D6 & $\begin{array}{l}\text { Mark 15:20, 22, 25, } \\
33-41\end{array}$ & $98 \mathrm{v}$ & \\
\hline S3W18D7 & $\begin{array}{l}\text { Luke 21:8-9, 25-27, } \\
33-36\end{array}$ & $99 \mathrm{r}$ & \\
\hline S3W19D1 & Matt. 25:31-46 & $99 \mathrm{r}$ & \\
\hline S3W19D2 & $\begin{array}{l}\text { Luke 19:29-40, } \\
22: 7-39\end{array}$ & $100 \mathrm{r}$ & \\
\hline S3W19D3 & $\begin{array}{l}\text { Luke 22:39-42, 45- } \\
71,23: 1\end{array}$ & $101 \mathrm{v}$ & \\
\hline S3W19D4 & - & - & \\
\hline S3W19D5 & $\begin{array}{l}\text { Luke 23:1-31,33, } \\
44-56\end{array}$ & $102 \mathrm{v}$ & \\
\hline S3W19D6 & - & - & \\
\hline S3W19D7 & Matt. 6:1-13 & $103 \mathrm{v}$ & \\
\hline S3W20D1 & Matt. 6:14-21 & $104 \mathrm{v}$ & \\
\hline S4W1D2 & - & $104 \mathrm{v}$ & $\begin{array}{l}\text { Read S3W18D7, Luke 21:8-9, 25-27, 33- } \\
36\end{array}$ \\
\hline S4W1D3 & - & $104 \mathrm{v}$ & Read S3W19D7, Matt. 6:1-13 \\
\hline S4W1D4 & - & $104 \mathrm{v}$ & Read S3W6D3, Luke 11:1-10 \\
\hline S4W1D5 & - & $104 \mathrm{v}$ & Read S3W8D5, Luke 13:1-9 \\
\hline S4W1D6 & John 15:1 & $104 \mathrm{v}$ & Read S1W7D2, John 15:1-7 \\
\hline S4W1D7 & Mark 2:23-3:5 & $105 \mathrm{r}$ & \\
\hline S4W2D1 & John 1:43-51 & $105 \mathrm{v}$ & \\
\hline S4W2D2 & - & - & \\
\hline S4W2D3 & - & - & \\
\hline S4W2D4 & - & - & \\
\hline S4W2D5 & - & - & \\
\hline S4W2D6 & - & - & \\
\hline S4W2D7 & Mark 1:35-44 & $105 \mathrm{v}$ & \\
\hline S4W3D1 & Mark 2:1-12 & $106 \mathrm{r}$ & \\
\hline S4W3D2 & - & - & \\
\hline S4W3D3 & - & - & \\
\hline S4W3D4 & - & - & \\
\hline
\end{tabular}




\begin{tabular}{|c|c|c|c|}
\hline Day & Text (written) & Folio & Cross-reference text to locate and read \\
\hline S4W3D5 & - & - & \\
\hline S4W3D6 & - & - & \\
\hline S4W3D7 & Mark 2:14-17 & $106 \mathrm{v}$ & \\
\hline S4W4D1 & Mark 8:34-9:1 & $106 \mathrm{v}$ & \\
\hline S4W4D2 & - & - & \\
\hline S4W4D3 & - & - & \\
\hline S4W4D4 & - & - & \\
\hline S4W4D5 & - & - & \\
\hline S4W4D6 & - & - & \\
\hline S4W4D7 & Mark 7:31-37 & $107 \mathrm{r}$ & \\
\hline S4W5D1 & Mark 9:17-31 & $107 \mathrm{r}$ & \\
\hline S4W5D2 & - & - & \\
\hline S4W5D3 & - & - & \\
\hline S4W5D4 & - & - & \\
\hline S4W5D5 & - & - & \\
\hline S4W5D6 & - & - & \\
\hline S4W5D7 & Mark 8:27-31 & $108 \mathrm{r}$ & \\
\hline S4W6D1 & Mark 10:32-45 & $108 \mathrm{r}$ & \\
\hline S4W6D2 & - & - & \\
\hline S4W6D3 & - & - & \\
\hline S4W6D4 & - & - & \\
\hline S4W6D5 & - & - & \\
\hline S4W6D6 & - & - & \\
\hline S4W6D7 & John 11:1-45 & $109 \mathrm{r}$ & \\
\hline S4W7D1a & $\begin{array}{l}\text { Matt. 21:1-11, 15- } \\
17 \text { (Matins) }\end{array}$ & $110 \mathrm{r}$ & Plus extra instructions \\
\hline S4W7D1b & $\begin{array}{l}\text { John 12:1-18 } \\
\text { (Liturgy) }\end{array}$ & $111 \mathrm{r}$ & \\
\hline S5W1D2a & Matt. 21:18-22:14 & $111 \mathrm{v}$ & \\
\hline S5W1D2b & - & $113 r$ & Read S2W9D5, Matt. 20:17-28 \\
\hline S5W1D2c & Mark 10:32 & $113 r$ & $\begin{array}{l}\text { Read S4W6D1, Mark 10:32-45, plus extra } \\
\text { instructions }\end{array}$ \\
\hline S5W1D3a & Matt. 22:15-24:2 & $113 \mathrm{v}$ & \\
\hline S5W1D3b & Matt. 24:3-26:2 & $116 \mathrm{r}$ & $\begin{array}{l}\text { (Two later corrections change this reading } \\
\text { firstly to S5W1D3c Compline, then to } \\
\text { S5W1D2b. The S5W1D3b reading is then } \\
\text { marked by the later hand at Matt. 24:36, } \\
\text { possibly ending 25:13.) }\end{array}$ \\
\hline S5W1D3c & - & $119 \mathrm{r}$ & Read S3W10D6, Luke 19:12-28 \\
\hline S5W1D4a & John 12:17-50 & $119 \mathrm{r}$ & \\
\hline
\end{tabular}




\begin{tabular}{|c|c|c|c|}
\hline Day & Text (written) & Folio & Cross-reference text to locate and read \\
\hline S5W1D4b & Matt. 26:6-16 & $120 \mathrm{v}$ & (Possibly also marked within S5W1D5d.) \\
\hline S5W1D4c & - & $121 \mathrm{r}$ & Read S3W4D2, Luke 7:36-50 \\
\hline S5W1D5a & Luke 22:1-39 & $121 \mathrm{r}$ & \\
\hline S5W1D5d & Matt. 26:2-20 & $122 \mathrm{r}$ & \\
\hline S5W1D5e & John 13:3-17 & $122 \mathrm{v}$ & $\begin{array}{l}\text { (S5W1D5c is marked within this lection, } \\
\text { John 13:12-17.) }\end{array}$ \\
\hline S5W1D5f & Matt. 26:21-39 & $123 r$ & \\
\hline S5W1D5g & Luke 22:43-45 & $123 \mathrm{v}$ & \\
\hline S5W1D5h & Matt. 26:40-27:2 & $124 \mathrm{r}$ & \\
\hline S5W1D5h+ & Mark 14:12-16 & $125 \mathrm{v}$ & \\
\hline S5W1D5i & John 13:31-18:1 & $126 \mathrm{r}$ & $\begin{array}{l}\text { (John 15:17-16:2 is marked, which } \\
\text { corresponds with S1W3D7 and M3D10c.) }\end{array}$ \\
\hline S5W1D5j & John 18:1-28 & $130 \mathrm{v}$ & \\
\hline S5W1D5k & Matt. 26:57-75 & $131 \mathrm{v}$ & \\
\hline S5W1D51 & John 18:29-19:16 & $132 \mathrm{v}$ & \\
\hline S5W1D5m & Matt. 27:3-32 & $133 \mathrm{v}$ & \\
\hline S5W1D5n & Mark 15:16-32 & $134 \mathrm{v}$ & \\
\hline S5W1D5o & Matt. 27:33-54 & $135 \mathrm{r}$ & \\
\hline S5W1D5p & Luke 23:32-49 & $136 \mathrm{r}$ & \\
\hline S5W1D5q & John 19:25-37 & $136 \mathrm{v}$ & \\
\hline S5W1D5r & Mark 15:43-47 & $137 \mathrm{r}$ & \\
\hline S5W1D5s & John 19:38-42 & $137 \mathrm{r}$ & \\
\hline S5W1D5t & Matt. 27:62-66 & $137 \mathrm{v}$ & \\
\hline S5W1D6a & Matt. 27:1-2, 55-56 & $137 \mathrm{v}$ & $\begin{array}{l}\text { Read S5W1D5m, Matt. 27:3-32, and } \\
\text { S5W1D5o, Matt. 27:33-54, in the middle } \\
\text { of the written verses }\end{array}$ \\
\hline S5W1D6b & $\begin{array}{l}\text { Mark 15:1-15, 32- } \\
41\end{array}$ & $138 \mathrm{r}$ & $\begin{array}{l}\text { Read S5W1D5n, Mark 15:16-32 in the } \\
\text { middle of the written verses }\end{array}$ \\
\hline S5W1D6c & Luke 22:66-23:32 & $138 \mathrm{v}$ & $\begin{array}{l}\text { Read S5W1D5p, Luke 23:32-49 to } \\
\text { complete the lection }\end{array}$ \\
\hline S5W1D6d & John 19:16-25 & $140 \mathrm{r}$ & $\begin{array}{l}\text { Read S5W1D5l, John 18:29-19:16 first, } \\
\text { then after the written text finish with } \\
\text { S5W1D5q, John 19:25-37 }\end{array}$ \\
\hline S5W1D6e & Matt. 27:1-38 & $140 \mathrm{v}$ & \\
\hline S5W1D6f & Luke 23:39-43 & $142 \mathrm{r}$ & \\
\hline S5W1D6g & Matt. 27:39-54 & $142 \mathrm{r}$ & \\
\hline S5W1D6h & John 19:31-37 & $142 \mathrm{v}$ & \\
\hline S5W1D6i & Matt. 27:55-61 & $143 r$ & \\
\hline S5W1D7a & Matt. 27:62 & $143 \mathrm{r}$ & Read S5W1D5t, Matt. 27:62-66 \\
\hline S5W1D7b & Matt. 28:1-20 & $143 \mathrm{r}$ & \\
\hline
\end{tabular}




\section{The Menologion}

\begin{tabular}{|c|c|c|c|}
\hline Day & Text (written) & Folio & Cross-reference text to locate and read \\
\hline M1D1a & Luke $4: 16$ & $144 \mathrm{v}$ & Read S3W1D5, Luke 4:16-22 \\
\hline M1D1b & Luke 1:39 & $144 \mathrm{v}$ & $\begin{array}{l}\text { Read M1D8a, Luke 1:39-49, 56, and/or } \\
\text { M1D8b, Luke 10:38-42; 11:27-28, and } \\
\text { also M5D20a which refers the reader to } \\
\text { S3W2D6, Luke 6:17-23, and/or M5D20b } \\
\text { which refers the reader to S4W2D5, Matt. } \\
\text { 11:27-30 }\end{array}$ \\
\hline M1D2a & - & $144 \mathrm{v}$ & $\begin{array}{l}\text { Read S1W7D2, John 15:1-7. (This is also } \\
\text { marked within S5W1D5i.) }\end{array}$ \\
\hline M1D2b & Matt. 5:14-19 & $144 \mathrm{v}$ & \\
\hline M1D3 & John 10:9-16 & $145 \mathrm{r}$ & $\begin{array}{l}\text { (An alternative lection may be offered for } \\
\text { this day, at M5D1b, Luke 2:20-21, 40-52.) }\end{array}$ \\
\hline M1D4a & - & $145 \mathrm{r}$ & Read S3W10D7, Luke 10:19-21 \\
\hline M1D4b & - & $145 \mathrm{r}$ & Read S2W17D7, Matt. 25:1-13 \\
\hline M1D4c & - & $145 \mathrm{r}$ & Read S1W2D6, John 5:30-6:2 \\
\hline M1D5 & - & $145 \mathrm{r}$ & $\begin{array}{l}\text { Read S2W11D4, Matt. 23:29-39 (Also } \\
\text { marked within S5W1D3a, Matt. 23:27-39). }\end{array}$ \\
\hline M1D6a & - & $145 \mathrm{r}$ & Read M2D18, Luke 10:16-21 \\
\hline M1D6b & - & $145 \mathrm{r}$ & Read M6D23, John 12:24-26, 35-36 \\
\hline M1D6c & Mark 12:28-29 & $145 \mathrm{v}$ & Read S3W16D4, Mark 12:28-37 \\
\hline M1D7a & - & $145 \mathrm{v}$ & Read S3W12D3, Luke 21:12-19 \\
\hline M1D7b & - & $145 \mathrm{v}$ & $\begin{array}{l}\text { Read M3D10a which refers the reader to } \\
\text { M4D6 and S3W2D6, Luke 6:17-23, and/or } \\
\text { M3D10b, Luke 14:25-27, 33-35, and/or } \\
\text { M3D10c which refers the reader to } \\
\text { S1W3D7, John 15:17-16:2 }\end{array}$ \\
\hline M1D8a & Luke 1:39-49, 56 & $145 \mathrm{v}$ & \\
\hline M1D8b & $\begin{array}{l}\text { Luke 10:38-42; } \\
11: 27-28\end{array}$ & $146 r$ & \\
\hline M1D9 & - & $146 \mathrm{r}$ & Read S3W6D7, Luke 8:16-21 \\
\hline M1D10a & - & $146 \mathrm{r}$ & Read S1W6D2, John 11:47-54 \\
\hline M1D10b & - & $146 \mathrm{r}$ & Read S2W17D7, Matt. 25:1-13 \\
\hline M1D11a & - & $146 \mathrm{r}$ & Read S1W4D6, John 8:21-30 \\
\hline M1D11b & - & $146 \mathrm{r}$ & Read M2D8, John 8:3-11 \\
\hline M1D12a & - & $146 \mathrm{r}$ & Read S1W4D7, John 8:31-42 \\
\hline M1D12b & - & $146 \mathrm{r}$ & Read S3W12D3, Luke 21:12-19 \\
\hline M1D12c & - & $146 \mathrm{v}$ & Read S1W3D7, John 15:17-16:2 \\
\hline M1D13a & John 12:25-36 & $146 \mathrm{v}$ & \\
\hline
\end{tabular}




\begin{tabular}{|c|c|c|c|}
\hline Day & Text (written) & Folio & Cross-reference text to locate and read \\
\hline M1D13b & - & $146 \mathrm{v}$ & $\begin{array}{l}\text { Read M4D22a which refers the reader to } \\
\text { S2W17D7, Matt. 25:1-13, and/or M4D22b } \\
\text { which refers the reader to S1W5D6, John } \\
\text { 10:22-28 }\end{array}$ \\
\hline M1D13c & - & $146 \mathrm{v}$ & Read S5W1D5o, Matt. 27:33-54 \\
\hline M1D13d & - & $147 \mathrm{r}$ & Read S2W7D7, Matt. 10:37-11:1 \\
\hline M1D13e & John 3:13-17 & $147 \mathrm{r}$ & \\
\hline M1D14a & John 12:28 & $147 \mathrm{r}$ & Read M1D13a, John 12:28-36 \\
\hline M1D14b & $\begin{array}{l}\text { John 19:6, 9-11, 13- } \\
20,25-28,30-35\end{array}$ & $147 \mathrm{r}$ & \\
\hline M1D14c & - & $148 \mathrm{r}$ & Read S1W3D3, John 6:27-33 \\
\hline M1D14d & - & $148 \mathrm{r}$ & Read S4W4D1, Mark 8:34-9:1 \\
\hline M1D15a & - & $148 \mathrm{r}$ & Read S1W3D7, John 15:17-16:2 \\
\hline M1D15b & - & $148 \mathrm{r}$ & $\begin{array}{l}\text { Read M1D2a which refers the reader to } \\
\text { S1W7D2, John 15:1-7, and/or M1D2b, } \\
\text { Matt. 5:14-19 }\end{array}$ \\
\hline M1D16 & - & $148 \mathrm{r}$ & Read S3W4D2, Luke 7:36-50 \\
\hline M1D17a & - & $148 \mathrm{r}$ & Read S2W17D7, Matt. 25:1-13 \\
\hline M1D17b & - & $148 \mathrm{r}$ & Read S3W5D3, Luke 9:23-27 \\
\hline M1D18a & - & $148 \mathrm{r}$ & Read S3W2D6, Luke 6:17-23 \\
\hline M1D18b & - & $148 \mathrm{r}$ & Read S2W17D7, Matt. 25:1-13 \\
\hline M1D19 & - & $148 \mathrm{r}$ & $\begin{array}{l}\text { Read S2W2D1, Matt. 10:32-33, 37-38; } \\
\text { 19:27-30 }\end{array}$ \\
\hline M1D20 & - & $148 \mathrm{r}$ & Read S3W12D3, Luke 21:12-19 \\
\hline M1D21a & - & $148 \mathrm{v}$ & Read M1D8a, Luke 1:39-49, 56 \\
\hline M1D21b & - & $148 \mathrm{v}$ & $\begin{array}{l}\text { Read M3D29, Matt. 10:17-18, 23-25, 28- } \\
31\end{array}$ \\
\hline M1D22a & - & $148 \mathrm{v}$ & Read S3W7D2, Luke 11:29-33 \\
\hline M1D22b & - & $148 \mathrm{v}$ & Read S1W3D7, John 15:17-16:2 \\
\hline M1D23 & - & $148 \mathrm{v}$ & Read M10D24b, Luke 1:5-25 \\
\hline M1D24 & - & $148 \mathrm{v}$ & Read S2W17D7, Matt. 25:1-13 \\
\hline M1D25a & - & $148 \mathrm{v}$ & Read S3W5D4, Luke 9:44-50 \\
\hline M1D25b & - & $148 \mathrm{v}$ & Read S3W6D4, Luke 11:9-13 \\
\hline M1D25c & - & $148 \mathrm{v}$ & $\begin{array}{l}\text { Read M3D10a which refers the reader to } \\
\text { M4D6 and S3W2D6, Luke 6:17-23, and/or } \\
\text { M3D10b, Luke 14:25-27, 33-35, and/or } \\
\text { M3D10c which refers the reader to } \\
\text { S1W3D7, John 15:17-16:2 }\end{array}$ \\
\hline M1D25d & - & $148 \mathrm{v}$ & Read S3W12D3, Luke 21:12-19 \\
\hline M1D25e & - & $148 \mathrm{v}$ & $\begin{array}{l}\text { Read M1D2a which refers the reader to } \\
\text { S1W7D2, John 15:1-7, and/or M1D2b, } \\
\text { Matt. 5:14-19 }\end{array}$ \\
\hline
\end{tabular}




\begin{tabular}{|c|c|c|c|}
\hline Day & Text (written) & Folio & Cross-reference text to locate and read \\
\hline M1D26 & - & $148 \mathrm{v}$ & $\begin{array}{l}\text { Read S1W7D7, which refers the reader to } \\
\text { read R11, John 21:14-25 (missing) }\end{array}$ \\
\hline M1D27 & - & $148 \mathrm{v}$ & Read S3W5D6, Luke 10:1-15 \\
\hline M1D28 & - & $148 \mathrm{v}$ & Read S2W4D5, Matt. 11:27-30 \\
\hline M1D29 & - & $148 \mathrm{v}$ & Read S3W5D3, Luke 9:23-27 \\
\hline M1D30a & Matt. 24:42-47 & $148 \mathrm{v}$ & \\
\hline M1D30b & - & $149 \mathrm{r}$ & $\begin{array}{l}\text { Probably a referral to S2W17D7, Matt. } \\
25: 1-13\end{array}$ \\
\hline M2D1a & - & $149 \mathrm{r}$ & Read S3W7D7, Luke 9:1-6 \\
\hline M2D1b & - & $149 \mathrm{r}$ & Read S3W5D3, Luke 9:23-27 \\
\hline M2D2 & - & $149 \mathrm{r}$ & Read M2D13, Matt. 7:12-21 \\
\hline M2D3 & - & $149 \mathrm{r}$ & Read S2W6D6, Matt. 13:44-54 \\
\hline M2D4 & - & $149 \mathrm{r}$ & $\begin{array}{l}\text { Read M1D27, which refers the reader to } \\
\text { read S3W5D6, Luke 10:1-15 }\end{array}$ \\
\hline M2D5 & - & $149 \mathrm{r}$ & Read S3W11D1, Luke 13:10-17 \\
\hline M2D6 & John 20:19 & $149 \mathrm{r}$ & $\begin{array}{l}\text { Read S1W1D1b, John 20:19ff, which may } \\
\text { refer to the text in S1W2D1 }\end{array}$ \\
\hline M2D7 & - & $149 \mathrm{r}$ & Read S3W3D3, Luke 6:37-45 \\
\hline M2D8 & John 8:3-11 & $149 \mathrm{r}$ & \\
\hline M2D9 & Matt. 10:1-7, 14-15 & $149 \mathrm{v}$ & \\
\hline M2D10 & - & $149 \mathrm{v}$ & Read S2W3D4, Matt. 10:16-22 \\
\hline M2D11a & - & $149 \mathrm{v}$ & Read M6D15, Luke 10:3-9 \\
\hline M2D11b & - & $149 \mathrm{v}$ & Read M3D6, Luke 12:8-12 \\
\hline M2D11c & Matt. 5:14 & $150 \mathrm{r}$ & Read M1D2b, Matt. 5:14-19 \\
\hline M2D11d & $\begin{array}{ll}\text { Mark } \quad 13: 33-37 \\
14: 3-9\end{array}$ & $150 \mathrm{r}$ & \\
\hline M2D11e & - & $150 \mathrm{v}$ & Read S3W5D1, Luke 8:5-15, 8 \\
\hline M2D12 & - & $150 \mathrm{v}$ & Read S3W12D3, Luke 21:12-19 \\
\hline M2D13 & Matt. 7:12-21 & $150 \mathrm{v}$ & \\
\hline M2D14 & - & $150 \mathrm{v}$ & Read S1W3D7, John 15:17-16:2 \\
\hline M2D15 & - & $151 \mathrm{r}$ & $\begin{array}{l}\text { Read M2D3, which refers the reader to read } \\
\text { S2W6D6, Matt. 13:44-54 }\end{array}$ \\
\hline M2D16a & - & $151 \mathrm{r}$ & $\begin{array}{l}\text { Read S2W2D1, Matt. 10:32-33, 37-38; } \\
\text { 19:27-30 }\end{array}$ \\
\hline M2D16b & - & $151 \mathrm{r}$ & $\begin{array}{l}\text { Read M3D10a which refers the reader to } \\
\text { M4D6 and S3W2D6, Luke 6:17-23, and/or } \\
\text { M3D10b, Luke 14:25-27, 33-35, and/or } \\
\text { M3D10c which refers the reader to } \\
\text { S1W3D7, John 15:17-16:2: }\end{array}$ \\
\hline M2D17a & - & $151 \mathrm{r}$ & Read S3W8D6, Luke 13:31-35 \\
\hline
\end{tabular}




\begin{tabular}{|c|c|c|c|}
\hline Day & Text (written) & Folio & Cross-reference text to locate and read \\
\hline M2D17b & - & $151 \mathrm{r}$ & Read S2W16D3, Mark 7:5-16 \\
\hline M2D18 & Luke 10:16-21 & $151 \mathrm{r}$ & \\
\hline M2D19 & - & $151 \mathrm{r}$ & Read S3W8D6, Luke 13:31-35 \\
\hline M2D20 & - & $151 \mathrm{r}$ & Read S3W10D7, Luke 10:19-21 \\
\hline M2D21 & - & $151 \mathrm{r}$ & Read S3W2D6, Luke 6:17-23 \\
\hline M2D22a & - & $151 \mathrm{r}$ & Read S3W2D6, Luke 6:17-23 \\
\hline M2D22b & - & $151 \mathrm{v}$ & Read S2W1D3, Matt. 4:23-5:13 \\
\hline M2D23a & - & $151 \mathrm{v}$ & Read S2W15D3, Mark 6:1-7 \\
\hline M2D23b & - & $151 \mathrm{v}$ & Read M1D3, John 10:9-16 \\
\hline M2D23c & - & $151 \mathrm{v}$ & Read S2W3D4, Matt. 10:16-22 \\
\hline M2D24 & - & $151 \mathrm{v}$ & Read S3W11D7, Luke 12:32-40 \\
\hline M2D25a & - & $151 \mathrm{v}$ & Read S3W7D6, Luke 12:2-12 \\
\hline M2D25b & - & $151 \mathrm{v}$ & $\begin{array}{l}\text { Read M2D3, which instructs the reader to } \\
\text { read S2W6D6, Matt. 13:44-54 }\end{array}$ \\
\hline M2D26a & - & $151 \mathrm{v}$ & Read S2W2D5, Matt. 8:23-27 \\
\hline M2D26b & - & $151 \mathrm{v}$ & Read S1W3D7, John 15:17-16:2 \\
\hline M2D27 & - & $151 \mathrm{v}$ & Read S2W3D4, Matt. 10:16-22 \\
\hline M2D28 & - & $151 \mathrm{v}$ & Read S3W12D3, Luke 21:12-19 \\
\hline M2D29a & - & $151 \mathrm{v}$ & Read S2W1D3, Matt. 4:23-5:13 \\
\hline M2D29b & - & $151 \mathrm{v}$ & Read S2W17D7, Matt. 25:1-13 \\
\hline M2D30 & - & $151 \mathrm{v}$ & Read S1W3D7, John 15:17-16:2 \\
\hline M2D31a & - & $151 \mathrm{v}$ & Read S4W4D1, Mark 8:34-9:1 \\
\hline M2D31b & - & $151 \mathrm{v}$ & Read S2W15D4, Mark 6:7-13 \\
\hline M3D1a & - & $151 \mathrm{v}$ & Read Matthew? Reference unclear. \\
\hline M3D1b & Matt. 10:1-8 & $151 \mathrm{v}$ & \\
\hline M3D2 & - & $152 \mathrm{r}$ & Read S3W12D3, Luke 21:12-19 \\
\hline M3D3a & - & $152 \mathrm{r}$ & Read S3W7D6, Luke 12:2-12 \\
\hline M3D3b & - & $152 \mathrm{r}$ & Read S3W10D3, Luke 17:26-37; 18:8 \\
\hline M3D4a & - & $152 \mathrm{r}$ & $\begin{array}{l}\text { Read M1D2a which refers the reader to } \\
\text { S1W7D2, John 15:1-7, and/or M1D2b, } \\
\text { Matt. 5:14-19 }\end{array}$ \\
\hline M3D4b & - & $152 \mathrm{r}$ & Read S2W17D7, Matt. 25:1-13 \\
\hline M3D5a & $\begin{array}{ll}\text { Mark } & 8: 34-35 \\
10: 29-31 & \\
\end{array}$ & $152 \mathrm{r}$ & \\
\hline M3D5b & - & $152 \mathrm{v}$ & Read S3W6D1, Luke 16:19-31 \\
\hline M3D6 & Luke 12:8-12 & $152 \mathrm{v}$ & \\
\hline M3D7a & - & $152 \mathrm{v}$ & Read S3W11D7, Luke 12:32-40 \\
\hline M3D7b & - & $152 \mathrm{v}$ & Read S2W17D7, Matt. 25:1-13 \\
\hline M3D8a & - & $152 \mathrm{v}$ & Read S2W1D2, Matt. 18:10-20 \\
\hline M3D8b & - & $152 \mathrm{v}$ & $\begin{array}{l}\text { Read M2D12, which instructs the reader to } \\
\text { read S3W12D3, Luke 21:12-19 }\end{array}$ \\
\hline M3D9a & John 15:1 & $152 \mathrm{v}$ & Read S1W7D2, John 15:1-7 \\
\hline
\end{tabular}




\begin{tabular}{|c|c|c|c|}
\hline Day & Text (written) & Folio & Cross-reference text to locate and read \\
\hline M3D9b & - & $152 \mathrm{v}$ & Read S2W17D7, Matt. 25:1-13 \\
\hline M3D10a & - & $152 \mathrm{v}$ & $\begin{array}{l}\text { Read M4D6, which refers the reader to read } \\
\text { S3W2D6, Luke 6:17-23 }\end{array}$ \\
\hline M3D10b & $\begin{array}{l}\text { Luke 14:25-27, 33- } \\
35\end{array}$ & $153 \mathrm{r}$ & \\
\hline M3D10c & - & $153 \mathrm{r}$ & Read S1W3D7, John 15:17-16:2 \\
\hline M3D11a & - & $153 \mathrm{r}$ & Read S1W7D2, John 15:1-7 \\
\hline M3D11b & - & $153 \mathrm{r}$ & Read M1D3, John 10:9-16 \\
\hline M3D12a & - & $153 \mathrm{r}$ & Read S2W1D3, Matt. 4:23-5:13 \\
\hline M3D12b & Matt. 5:14 & $153 \mathrm{r}$ & Read M1D2b, Matt. 5:14-19 \\
\hline M3D13a & John 10:1-9 & $153 \mathrm{r}$ & \\
\hline M3D13b & - & $153 v$ & Read M1D3, John 10:9-16 \\
\hline M3D14a & - & $153 v$ & Read S4W2D1, John 1:43-51 \\
\hline M3D14b & - & $153 v$ & Read M3D13a, John 10:1-9 \\
\hline M3D15 & - & $153 \mathrm{v}$ & Read S3W7D6, Luke 12:2-12 \\
\hline M3D16a & - & $153 \mathrm{v}$ & Read S2W5D7, Matt. 9:9-13 \\
\hline M3D16b & John 15:1 & $153 \mathrm{v}$ & Read S1W7D2, John 15:1-7 \\
\hline M3D17 & - & $153 \mathrm{v}$ & $\begin{array}{l}\text { Read M3D1a, Matthew reference unclear, } \\
\text { and/or M3D1b, Matt. 10:1-8 }\end{array}$ \\
\hline M3D18 & - & $153 v$ & Read S1W3D7, John 15:17-16:2 \\
\hline M3D19 & - & $153 v$ & Read S3W7D2, Luke 11:29-33 \\
\hline M3D20 & - & $153 v$ & $\begin{array}{l}\text { Read M1D2a which refers the reader to } \\
\text { S1W7D2, John 15:1-7, and/or M1D2b, } \\
\text { Matt. 5:14-19 }\end{array}$ \\
\hline M3D21a & - & $153 \mathrm{v}$ & Read S3W6D7, Luke 8:16-21 \\
\hline M3D21b & - & $153 \mathrm{v}$ & Read M1D8a, Luke 1:39-49, 56 \\
\hline M3D22a & - & $153 v$ & $\begin{array}{l}\text { Read M3D29, Matt. 10:17-18, 23-25, 28- } \\
31\end{array}$ \\
\hline M3D22b & - & $153 v$ & Read S2W17D7, Matt. 25:1-13 \\
\hline M3D23 & - & $153 v$ & $\begin{array}{l}\text { Read M1D2a which refers the reader to } \\
\text { S1W7D2, John 15:1-7, and/or M1D2b, } \\
\text { Matt. 5:14-19 }\end{array}$ \\
\hline M3D24 & - & $153 v$ & $\begin{array}{l}\text { Read M1D30a, Matt. } 24: 42-47 \text {, and/or } \\
\text { M1D30b, which probably refers to } \\
\text { S2W17D7, Matt. } 25: 1-13\end{array}$ \\
\hline M3D25a & - & $153 v$ & Read S1W3D7, John 15:17-16:2 \\
\hline M3D25b & - & $153 v$ & Read S2W15D2, Mark 5:24-34 \\
\hline M3D26 & - & $153 v$ & Read S2W4D5, Matt. 11:27-30 \\
\hline M3D27 & - & $154 \mathrm{r}$ & Read S1W7D2, John 15:1-7 \\
\hline M3D28 & - & $154 \mathrm{r}$ & Read S4W4D1, Mark 8:34-9:1 \\
\hline
\end{tabular}




\begin{tabular}{|c|c|c|c|}
\hline Day & Text (written) & Folio & Cross-reference text to locate and read \\
\hline M3D29 & $\begin{array}{l}\text { Matt. 10:17-18, 23- } \\
25,28-31\end{array}$ & $154 \mathrm{r}$ & \\
\hline M3D30 & - & $154 \mathrm{r}$ & Read S1W1D4, John 1:35-51 \\
\hline M4D1 & - & $154 \mathrm{r}$ & Read S2W11D4, Matt. 23:29-39 \\
\hline M4D2a & - & $154 \mathrm{r}$ & Read S3W8D6, Luke 13:31-35 \\
\hline $\mathrm{M} 4 \mathrm{D} 2 \mathrm{~b}$ & - & $154 \mathrm{r}$ & Read S3W11D7, Luke 12:32-40 \\
\hline M4D3a & - & $154 \mathrm{v}$ & Read S3W1D6, Luke 4:22-30 \\
\hline M4D3b & - & $154 \mathrm{v}$ & $\begin{array}{l}\text { Read S2W2D1, Matt. 10:32-33, 37-38; } \\
\text { 19:27-30 }\end{array}$ \\
\hline M4D4a & - & $154 \mathrm{v}$ & Read S2W15D2, Mark 5:24-34 \\
\hline M4D4b & - & $154 \mathrm{v}$ & Read S2W4D5, Matt. 11:27-30 \\
\hline M4D5 & - & $154 \mathrm{v}$ & $\begin{array}{l}\text { Read M5D20a which refers the reader to } \\
\text { S3W2D6, Luke 6:17-23, and/or M5D20b } \\
\text { which refers to S2W4D5, Matt. 11:27-30 }\end{array}$ \\
\hline M4D6 & - & $154 \mathrm{v}$ & Read S3W2D6, Luke 6:17-23 \\
\hline M4D7 & - & $154 \mathrm{v}$ & Read M3D13a, John 10:1-9 \\
\hline M4D8 & - & $154 \mathrm{v}$ & Read S3W5D3, Luke 9:23-27 \\
\hline M4D9 & - & $154 \mathrm{v}$ & Read S3W6D7, Luke 8:16-21 \\
\hline M4D10 & - & $154 \mathrm{v}$ & Read S2W3D4, Matt. 10:16-22 \\
\hline M4D11 & - & $154 \mathrm{v}$ & $\begin{array}{l}\text { Read M3D10a which refers the reader to } \\
\text { M4D6 and S3W2D6, Luke 6:17-23, and/or } \\
\text { M3D10b, Luke 14:25-27, 33-35, and/or } \\
\text { M3D10c which refers the reader to } \\
\text { S1W3D7, John 15:17-16:2 }\end{array}$ \\
\hline M4D12 & - & $154 \mathrm{v}$ & Read M1D3, John 10:9-16 \\
\hline M4D13 & - & $154 \mathrm{v}$ & Read S3W12D3, Luke 21:12-19 \\
\hline M4D14 & - & $154 \mathrm{v}$ & Read S2W5D4, Matt. 12:38-45 \\
\hline M4D15 & - & $154 \mathrm{v}$ & $\begin{array}{l}\text { Read M3D5a, Mark 8:34-35; 10:29-31, } \\
\text { and/or M3D5b which refers the reader to } \\
\text { S3W6D1, Luke 16:19-31 }\end{array}$ \\
\hline M4D16 & - & $154 \mathrm{v}$ & Read S3W10D3, Luke 17:26-37; 18:8 \\
\hline M4D17 & Luke 11:44-50 & $154 \mathrm{v}$ & \\
\hline M4D18a & - & $155 \mathrm{r}$ & Read S4W4D1, Mark 8:34-9:1 \\
\hline M4D18b & - & $155 \mathrm{r}$ & Read S3W5D3, Luke 9:23-27 \\
\hline M4D19 & - & $155 \mathrm{r}$ & Read S3W12D3, Luke 21:12-19 \\
\hline M4D20 & - & $155 \mathrm{r}$ & Read S3W13D6, Mark 9:33-41 \\
\hline M4D21 & - & $155 \mathrm{r}$ & Read S3W4D2, Luke 7:36-50 \\
\hline M4D22a & - & $155 \mathrm{r}$ & Read S2W17D7, Matt. 25:1-13 \\
\hline M4D22b & John 10:22 & $155 \mathrm{r}$ & Read S1W5D6, John 10:22-28 \\
\hline M4D23a & - & $155 \mathrm{r}$ & $\begin{array}{l}\text { Read M10D29a which refers the reader to } \\
\text { M2D9, Matt. 10:1-7, 14-15, and/or } \\
\text { M10D29b, Matt. 16:13-19 }\end{array}$ \\
\hline
\end{tabular}




\begin{tabular}{|c|c|c|c|}
\hline Day & Text (written) & Folio & Cross-reference text to locate and read \\
\hline M4D23b & - & $155 \mathrm{r}$ & Read S1W3D7, John 15:17-16:2 \\
\hline M4D23c & - & $155 \mathrm{r}$ & $\begin{array}{l}\text { Read S3W12D7, Luke 13:19-29, plus extra } \\
\text { instructions }\end{array}$ \\
\hline M4D23d & Matt. 1:1-25 & $155 \mathrm{r}$ & Plus extra instructions after the lection \\
\hline M4D24a & - & - & $\begin{array}{l}\text { No instructions. The lection is marked in } \\
\text { the middle of M4D23d, Matt. 1:18-25 }\end{array}$ \\
\hline M4D24b & Luke 2:1-20 & $156 \mathrm{v}$ & \\
\hline M4D24c & - & - & $\begin{array}{l}\text { No instructions. The lection is marked } \\
\text { alongside M4D25b, Luke 2:1-20, possibly } \\
\text { ending v. } 12 \text {. }\end{array}$ \\
\hline M4D24d & - & - & $\begin{array}{l}\text { No instructions. The lection is marked } \\
\text { alongside M4D26a, Matt 2:13-23 }\end{array}$ \\
\hline M4D24e & - & $157 \mathrm{r}$ & Read S2W17D7, Matt. 25:1-13 \\
\hline M4D25a & Matt. 1:18 & $157 \mathrm{r}$ & $\begin{array}{l}\text { Read from the middle of M4D23d, Matt. } \\
1: 18-25\end{array}$ \\
\hline M4D25b & Matt 2:1-12 & $157 \mathrm{r}$ & \\
\hline M4D26a & Matt 2:13-23 & $158 \mathrm{r}$ & \\
\hline M4D26b & Matt 12:15-21 & $158 \mathrm{v}$ & \\
\hline M4D26c & - & $158 \mathrm{v}$ & $\begin{array}{l}\text { Instructions about the number of Sundays } \\
\text { between Christmas and Epiphany }\end{array}$ \\
\hline M4D27 & - & $158 \mathrm{v}$ & $\begin{array}{l}\text { Read S2W14D1, Matt. 21:33-42, plus extra } \\
\text { instructions }\end{array}$ \\
\hline M4D28a & - & $159 \mathrm{r}$ & $\begin{array}{l}\text { Read M1D2a which refers the reader to } \\
\text { S1W7D2, John 15:1-7, and/or M1D2b, } \\
\text { Matt. 5:14-19 }\end{array}$ \\
\hline $\mathrm{M} 4 \mathrm{D} 28 \mathrm{~b}$ & - & $159 \mathrm{r}$ & Read S3W11D7, Luke 12:32-40 \\
\hline M4D29a & - & $159 \mathrm{r}$ & Read M4D26a, Matt 2:13-18 \\
\hline M4D29b & - & $159 \mathrm{r}$ & $\begin{array}{l}\text { Read M3D10a which refers the reader to } \\
\text { M4D6 and S3W2D6, Luke 6:17-23, and/or } \\
\text { M3D10b, Luke 14:25-27, 33-35, and/or } \\
\text { M3D10c which refers the reader to } \\
\text { S1W3D7, John 15:17-16:2 }\end{array}$ \\
\hline M4D30a & - & $159 \mathrm{r}$ & Read S2W15D3, Mark 6:1-7 \\
\hline M4D30b & - & $159 \mathrm{r}$ & Read S2W17D7, Matt. 25:1-13 \\
\hline M4D31a & - & $159 \mathrm{r}$ & Read S2W16D1, Matt. 22:35-46 \\
\hline M4D31b & - & $159 \mathrm{r}$ & Read S4W4D1, Mark 8:34-9:1 \\
\hline M5D1a & - & $159 \mathrm{r}$ & $\begin{array}{l}\text { Read M4D6, which refers the reader to read } \\
\text { S3W2D6, Luke 6:17-23 }\end{array}$ \\
\hline M5D1b & $\begin{array}{l}\text { Luke } 2: 20-21,40- \\
52\end{array}$ & $159 \mathrm{r}$ & \\
\hline
\end{tabular}




\begin{tabular}{|c|c|c|c|}
\hline Day & Text (written) & Folio & Cross-reference text to locate and read \\
\hline M5D2a & - & $159 \mathrm{v}$ & Read S1W1D5, John 3:1-15 \\
\hline M5D2b & - & $159 \mathrm{v}$ & Read M3D13a, John 10:1-9 \\
\hline M5D3a & Matt. 3:1, 5-11 & $159 \mathrm{v}$ & \\
\hline M5D3b & - & $160 \mathrm{r}$ & Read S1W3D7, John 15:17-16:2 \\
\hline M5D3c & - & $160 \mathrm{r}$ & Read S2W11D4, Matt. 23:29-39 \\
\hline M5D4a & John 1:19 & $160 \mathrm{r}$ & Read S1W1D2, John 1:19-28 \\
\hline M5D4b & - & $160 \mathrm{r}$ & Read S3W5D6, Luke 10:1-15 \\
\hline M5D5a & - & $160 \mathrm{r}$ & $\begin{array}{l}\text { Read S2W4D5, Matt. 11:27-30. (See also } \\
\text { Matt. 3:1, 5-11 in M5D3a where this lection } \\
\text { is marked.) }\end{array}$ \\
\hline M5D5b & Matt. 3:1-6 & $160 \mathrm{r}$ & \\
\hline M5D5c & Mark 1:1-8 & $160 \mathrm{v}$ & \\
\hline M5D5d & Luke 3:1-18 & $160 \mathrm{v}$ & \\
\hline M5D5e & - & $161 \mathrm{v}$ & $\begin{array}{l}\text { Read M3D5a, Mark } 8: 34-35 ; 10: 29-31 \text {, } \\
\text { and/or M3D5b which refers the reader to } \\
\text { read S3W6D1, Luke 16:19-31 }\end{array}$ \\
\hline M5D6a & Mark 1:9-11 & $161 \mathrm{v}$ & \\
\hline M5D6b & Matt 3:13-17 & $161 \mathrm{v}$ & \\
\hline M5D7a & John 1:29-34 & $162 \mathrm{r}$ & \\
\hline M5D7b & Matt 4:1-11 & $162 \mathrm{r}$ & \\
\hline M5D7c & Matt 4:12-17 & $162 \mathrm{v}$ & \\
\hline M5D8a & - & $163 r$ & Read S1W1D7, John 3:22-33 \\
\hline M5D8b & - & $163 r$ & Read S2W3D4, Matt. 10:16-22 \\
\hline M5D9a & $\begin{array}{l}\text { Luke 3:21-22, 4:1- } \\
2,4: 14-15\end{array}$ & $163 r$ & \\
\hline M5D9b & - & $163 \mathrm{r}$ & Read S3W12D3, Luke 21:12-19 \\
\hline M5D9c & - & $163 r$ & Read S3W4D4, Luke 8:22-25 \\
\hline M5D10a & - & $163 \mathrm{r}$ & Read S3W3D5, Luke 7:18-30 \\
\hline M5D10b & - & $163 r$ & Read S2W1D3, Matt. 4:23-5:13 \\
\hline M5D11a & - & $163 r$ & Read S3W11D4, Luke 20:1-8 \\
\hline M5D11b & - & $163 \mathrm{r}$ & $\begin{array}{l}\text { Read S3W2D6, Luke 6:17-23 (An } \\
\text { additional morning reading is added here, } \\
\text { instructing the reader to find M5D20b, } \\
\text { Matt. 11:27-30.) }\end{array}$ \\
\hline M5D12a & John 10:39-42 & $163 \mathrm{v}$ & \\
\hline M5D12b & - & $163 \mathrm{v}$ & Read S2W4D5, Matt. 11:27-30 \\
\hline M5D12c & - & $163 \mathrm{v}$ & Read S2W15D2, Mark 5:24-34 \\
\hline M5D13a & - & $163 \mathrm{v}$ & Read M5D6a, Mark 1:9-11 \\
\hline M5D13b & - & $163 \mathrm{v}$ & Read S2W3D4, Matt. 10:16-22 \\
\hline M5D14 & - & $163 \mathrm{v}$ & Read S3W11D7, Luke 12:32-40 \\
\hline M5D15 & - & $163 \mathrm{v}$ & Read S2W1D3, Matt. 4:23-5:13 \\
\hline
\end{tabular}




\begin{tabular}{|c|c|c|c|}
\hline Day & Text (written) & Folio & Cross-reference text to locate and read \\
\hline M5D16a & - & $163 \mathrm{v}$ & $\begin{array}{l}\text { Read S1W7D7 or R11, John 21:14-25 } \\
\text { (missing) }\end{array}$ \\
\hline M5D16b & - & $163 v$ & Read S1W3D7, John 15:17-16:2 \\
\hline M5D17a & - & $163 \mathrm{v}$ & Read M2D18, Luke 10:16-21 \\
\hline M5D17b & - & $163 \mathrm{v}$ & Read S3W2D6, Luke 6:17-23 \\
\hline M5D18 & Matt. 5:14 & $163 v$ & Read M1D2b, Matt. 5:14-19 \\
\hline M5D19 & - & $163 v$ & Read S3W2D6, Luke 6:17-23 \\
\hline M5D20a & - & $163 v$ & Read S3W2D6, Luke 6:17-23 \\
\hline M5D20b & Matt. 11:27 & $163 \mathrm{v}$ & Read S2W4D5, Matt. 11:27-30 \\
\hline M5D21a & - & $163 \mathrm{v}$ & Read M3D6, Luke 12:8-12 \\
\hline M5D21b & John 15:1 & $163 \mathrm{v}$ & Read S1W7D2, John 15:1-7 \\
\hline M5D22 & - & $164 \mathrm{r}$ & $\begin{array}{l}\text { Read S2W2D1, Matt. 10:32-33, 37-38; } \\
\text { 19:27-30 }\end{array}$ \\
\hline M5D23 & - & $164 \mathrm{r}$ & Read S2W4D6, Matt. 12:1-8 \\
\hline M5D24a & - & $164 \mathrm{r}$ & Read S2W16D5, Mark 7:24-30 \\
\hline M5D24b & John 15:1 & $164 \mathrm{r}$ & Read S1W7D2, John 15:1-7 \\
\hline M5D25a & - & $164 \mathrm{r}$ & $\begin{array}{l}\text { Read M1D2a which refers the reader to } \\
\text { S1W7D2, John 14:27-15:7, starting at 15:1, } \\
\text { and/or M1D2b, Matt. 5:14-19 }\end{array}$ \\
\hline M5D25b & - & $164 \mathrm{r}$ & Read S4W4D1, Mark 8:34-9:1 \\
\hline M5D26 & - & $164 \mathrm{r}$ & Read S3W11D7, Luke 12:32-40 \\
\hline M5D27 & - & $164 \mathrm{r}$ & $\begin{array}{l}\text { Read M3D13a, John } 10: 1-9 \text { and/or } \\
\text { M3D13b which refers the reader to M1D3, } \\
\text { John 10:9-16 }\end{array}$ \\
\hline M5D28 & - & $164 \mathrm{r}$ & Read S3W2D5, Luke 6:12-19 \\
\hline M5D29 & - & $164 \mathrm{r}$ & Read S3W13D6, Mark 13:1-8 \\
\hline M5D30 & - & $164 \mathrm{r}$ & Read M6D23, John 12:24-26, 35-36 \\
\hline M5D31 & - & $164 \mathrm{r}$ & $\begin{array}{l}\text { Read M3D1a, Matthew reference unclear, } \\
\text { and/or M3D1b, Matt. 10:1-8 }\end{array}$ \\
\hline M6D1 & - & $164 \mathrm{r}$ & Read S3W10D7, Luke 10:19-21 \\
\hline M6D2a & Luke $2: 25$ and 32 & $164 \mathrm{r}$ & Read M6D2b, Luke 2:25-32 \\
\hline M6D2b & Luke 2:22-40 & $164 \mathrm{r}$ & \\
\hline M6D3 & - & $165 \mathrm{r}$ & Read M6D2b, Luke 2:25-38 \\
\hline M6D4a & - & $165 \mathrm{r}$ & Read S3W2D6, Luke 6:17-23 \\
\hline M6D4b & - & $165 \mathrm{r}$ & $\begin{array}{l}\text { Read M3D10a which refers the reader to } \\
\text { M4D6 and S3W2D6, Luke 6:17-23, and/or } \\
\text { M3D10b, Luke 14:25-27, 33-35, and/or } \\
\text { M3D10c which refers the reader to } \\
\text { S1W3D7, John 15:17-16:2 }\end{array}$ \\
\hline M6D5 & - & $165 \mathrm{r}$ & Read S3W16D5, Mark 12:38-44 \\
\hline
\end{tabular}




\begin{tabular}{|c|c|c|c|}
\hline Day & Text (written) & Folio & Cross-reference text to locate and read \\
\hline M6D6 & - & $165 \mathrm{r}$ & Read S3W7D7, Luke 9:1-6 \\
\hline M6D7 & Matt. 5:14 & $165 \mathrm{r}$ & Read M1D2b, Matt. 5:14-19 \\
\hline M6D8a & - & $165 \mathrm{r}$ & Read S2W11D4, Matt. 23:29-39 \\
\hline M6D8b & - & $165 \mathrm{r}$ & Read S2W3D4, Matt. 10:16-22 \\
\hline M6D9a & - & $165 \mathrm{r}$ & Read S1W3D7, John 15:17-16:2 \\
\hline M6D9b & - & $165 \mathrm{r}$ & Read M1D3, John 10:9-16 \\
\hline M6D10 & - & $165 \mathrm{r}$ & Read S3W12D3, Luke 21:12-19 \\
\hline M6D11 & John 15:1 & $165 \mathrm{r}$ & Read S1W7D2, John 15:1-7 \\
\hline M6D12 & Matt. 5:14 & $165 \mathrm{r}$ & Read M1D2b, Matt. 5:14-19 \\
\hline M6D13 & - & $165 \mathrm{r}$ & Read S2W4D5, Matt. 11:27-30 \\
\hline M6D14 & - & $165 r$ & $\begin{array}{l}\text { Read M3D1a, Matthew reference unclear, } \\
\text { and/or M3D1b, Matt. 10:1-8 }\end{array}$ \\
\hline M6D15 & Luke 10:3-9 & $165 \mathrm{r}$ & \\
\hline M6D16 & - & $165 \mathrm{v}$ & Read S3W12D3, Luke 21:12-19 \\
\hline M6D17a & John 15:1 & $165 \mathrm{v}$ & Read S1W7D2, John 15:1-7 \\
\hline M6D17b & - & $165 v$ & Read S2W17D7, Matt. 25:1-13 \\
\hline M6D18a & - & $165 \mathrm{v}$ & $\begin{array}{l}\text { Read M1D2a which refers the reader to } \\
\text { S1W7D2, John 15:1-7, and/or M1D2b, } \\
\text { Matt. 5:14-19 }\end{array}$ \\
\hline M6D18b & - & $165 \mathrm{v}$ & $\begin{array}{l}\text { Read S2W2D1, Matt. 10:32-33, 37-38; } \\
\text { 19:27-30 }\end{array}$ \\
\hline M6D19a & - & $165 \mathrm{v}$ & $\begin{array}{l}\text { Read S2W2D1, Matt. 10:32-33, 37-38; } \\
\text { 19:27-30 }\end{array}$ \\
\hline M6D19b & Matt. 5:14 & $165 \mathrm{v}$ & Read M1D2b, Matt. 5:14-19 \\
\hline M6D20a & - & $165 \mathrm{v}$ & $\begin{array}{l}\text { Read M4D6, which in turn refers the reader } \\
\text { to read S3W2D6, Luke 6:17-23 }\end{array}$ \\
\hline M6D20b & - & $165 v$ & $\begin{array}{l}\text { Read M1D2a which refers the reader to } \\
\text { S1W7D2, John 15:1-7, and/or M1D2b, } \\
\text { Matt. 5:14-19 }\end{array}$ \\
\hline M6D21 & - & $165 \mathrm{v}$ & Read M3D13a, John 10:1-9 \\
\hline M6D22a & - & $165 \mathrm{v}$ & Read M1D3, John 10:9-16 \\
\hline M6D22b & - & $165 v$ & $\begin{array}{l}\text { Read S2W2D1, Matt. 10:32-33, 37-38; } \\
\text { 19:27-30 }\end{array}$ \\
\hline M6D23 & $\begin{array}{l}\text { John } 12: 24-26,35- \\
36\end{array}$ & $165 \mathrm{v}$ & \\
\hline M6D24a & - & $166 \mathrm{r}$ & Read S3W3D5, Luke 7:17-30 \\
\hline M6D24b & - & $166 \mathrm{r}$ & Read S2W4D2, Matt. 11:2-15 \\
\hline M6D25a & - & $166 \mathrm{r}$ & Read M1D3, John 10:9-16 \\
\hline M6D25b & - & $166 \mathrm{r}$ & Read S3W12D3, Luke 21:12-19 \\
\hline M6D26 & - & $166 \mathrm{r}$ & $\begin{array}{l}\text { Read M1D2a which refers the reader to } \\
\text { S1W7D2, John 15:1-7, and/or M1D2b, } \\
\text { Matt. 5:14-19 }\end{array}$ \\
\hline
\end{tabular}




\begin{tabular}{|c|c|c|c|}
\hline Day & Text (written) & Folio & Cross-reference text to locate and read \\
\hline M6D27 & - & $166 \mathrm{r}$ & Read M3D6, Luke 12:8-12 \\
\hline M6D28 & - & $166 \mathrm{r}$ & Read S3W7D6, Luke 12:2-12 \\
\hline M6D29 & - & $166 \mathrm{r}$ & Read S3W12D3, Luke 21:12-19 \\
\hline M7D1 & - & $166 \mathrm{r}$ & Read S2W15D2, Mark 5:24-34 \\
\hline M7D2 & - & $166 \mathrm{r}$ & Read S1W7D2, John 14:27-15:7 \\
\hline M7D3 & - & $166 \mathrm{r}$ & Read S3W10D7, Luke 10:19-21 \\
\hline M7D4 & - & $166 \mathrm{r}$ & Read S3W17D2, Mark 13:9-13 \\
\hline M7D5 & - & $166 \mathrm{r}$ & Read S3W3D4, Luke 6:46-7:1 \\
\hline M7D6 & - & $166 \mathrm{r}$ & Read S2W9D4, Matt. 20:1-16 \\
\hline M7D7 & - & $166 r$ & $\begin{array}{l}\text { Read S2W2D1, Matt. 10:32-33, 37-38; } \\
\text { 19:27-30 }\end{array}$ \\
\hline M7D8 & - & $166 \mathrm{r}$ & Read M3D6, Luke 12:8-12 \\
\hline M7D9 & - & $166 \mathrm{r}$ & Read S2W9D4, Matt. 20:1-16 \\
\hline M7D10 & - & $166 \mathrm{r}$ & Read S1W7D2, John 15:1-7 \\
\hline M7D11 & - & $166 \mathrm{r}$ & Read S2W1D3, Matt. 4:23-5:13 \\
\hline M7D12 & - & $166 \mathrm{r}$ & Read M3D6, Luke 12:8-12 \\
\hline M7D13a & - & $166 \mathrm{r}$ & Read M1D3, John 10:9-16 \\
\hline M7D13b & - & $166 \mathrm{r}$ & Read S3W11D7, Luke 12:32-40 \\
\hline M7D14 & - & $166 \mathrm{r}$ & Read S1W3D7, John 15:17-16:2 \\
\hline M7D15 & - & $166 \mathrm{r}$ & $\begin{array}{l}\text { Read M4D6, which refers the reader to } \\
\text { S3W2D6, Luke 6:17-23 }\end{array}$ \\
\hline M7D16 & - & $166 \mathrm{r}$ & Read S3W12D3, Luke 21:12-19 \\
\hline M7D17 & - & $166 \mathrm{r}$ & Read S2W4D5, Matt. 11:27-30 \\
\hline M7D18 & - & $166 \mathrm{r}$ & $\begin{array}{l}\text { Read M1D2a which refers the reader to } \\
\text { S1W7D2, John 14:27-15:7, starting at 15:1, } \\
\text { and/or M1D2b, Matt. 5:14-19 }\end{array}$ \\
\hline M7D19 & - & $166 \mathrm{r}$ & Read S3W12D3, Luke 21:12-19 \\
\hline M7D20a & - & $166 \mathrm{v}$ & Read S3W11D7, Luke 12:32-40 \\
\hline M7D20b & - & $166 \mathrm{v}$ & $\begin{array}{l}\text { Read M3D10a which refers the reader to } \\
\text { M4D6 and S3W2D6, Luke 6:17-23, and/or } \\
\text { M3D10b, Luke 14:25-27, 33-35, and/or } \\
\text { M3D10c which refers the reader to } \\
\text { S1W3D7, John 15:17-16:2 }\end{array}$ \\
\hline M7D21 & - & $166 \mathrm{v}$ & Read S3W5D3, Luke 9:23-27 \\
\hline M7D22 & - & $166 \mathrm{v}$ & $\begin{array}{l}\text { Read M2D3, which refers the reader to read } \\
\text { S2W6D6, Matt. 13:44-54 }\end{array}$ \\
\hline M7D23a & - & $166 \mathrm{v}$ & Read S3W4D2, Luke 7:36-50 \\
\hline M7D23b & - & $166 \mathrm{v}$ & Read S3W4D2, Luke 7:36-50 \\
\hline M7D24 & - & $166 \mathrm{v}$ & Read S1W3D7, John 15:17-16:2 \\
\hline M7D25a & - & $166 \mathrm{v}$ & Read M1D8a, Luke 1:39-49, 56 \\
\hline
\end{tabular}




\begin{tabular}{|c|c|c|c|}
\hline Day & Text (written) & Folio & Cross-reference text to locate and read \\
\hline M7D25b & Luke 1:24-38 & $166 \mathrm{v}$ & \\
\hline M7D26a & - & $167 \mathrm{r}$ & Read M2D18, Luke 10:16-21 \\
\hline M7D26b & - & $167 \mathrm{r}$ & $\begin{array}{l}\text { Read M3D10a which refers the reader to } \\
\text { M4D6 and S3W2D6, Luke 6:17-23, and/or } \\
\text { M3D10b, Luke 14:25-27, 33-35, and/or } \\
\text { M3D10c which refers the reader to } \\
\text { S1W3D7, John 15:17-16:2 }\end{array}$ \\
\hline M7D27 & - & $167 \mathrm{r}$ & $\begin{array}{l}\text { Read M2D11a which refers the reader to } \\
\text { M6D15, Luke 10:3-9, and/or M2D11b } \\
\text { which refers the reader to M3D6, Luke } \\
\text { 12:8-12, and/or M2D11c which refers the } \\
\text { reader to M1D2b, Matt. 5:14-19, and/or } \\
\text { M2D11d, Mark 13:33-37; 14:3-9, and/or } \\
\text { M2D11e which refers to S3W5D1, Luke } \\
\text { 8:5-15, 8 }\end{array}$ \\
\hline M7D28a & - & $167 \mathrm{r}$ & Read S3W2D6, Luke 6:17-23 \\
\hline M7D28b & - & $167 \mathrm{r}$ & Read S1W3D7, John 15:17-16:2 \\
\hline M7D29a & - & $167 \mathrm{r}$ & Read M1D3, John 10:9-16 \\
\hline M7D29b & - & $167 \mathrm{r}$ & Read S2W1D3, Matt. 4:23-5:13 \\
\hline M7D30 & - & $167 \mathrm{r}$ & Read S2W4D5, Matt. 11:27-30 \\
\hline M7D31 & - & $167 \mathrm{r}$ & Read S3W12D3, Luke 21:12-19 \\
\hline M8D1 & - & $167 \mathrm{v}$ & Read M2D8, John 8:3-11 \\
\hline M8D2a & - & $167 \mathrm{v}$ & Read S3W10D7, Luke 10:19-21 \\
\hline M8D2b & - & $167 \mathrm{v}$ & $\begin{array}{l}\text { Read M3D1a, Matthew reference unclear, } \\
\text { and/or M3D1b, Matt. 10:1-8 }\end{array}$ \\
\hline M8D3 & - & $167 \mathrm{v}$ & Read S2W4D5, Matt. 11:27-30 \\
\hline M8D4 & - & $167 \mathrm{v}$ & Read S3W12D3, Luke 21:12-19 \\
\hline M8D5a & - & $167 \mathrm{v}$ & Read S4W4D1, Mark 8:34-9:1 \\
\hline M8D5b & - & $167 \mathrm{v}$ & Read S3W11D1, Luke 13:10-17 \\
\hline M8D6a & Matt. 5:14 & $167 \mathrm{v}$ & Read M1D2b, Matt. 5:14-19 \\
\hline M8D6b & - & $167 \mathrm{v}$ & Read S3W11D7, Luke 12:32-40 \\
\hline M8D7a & - & $167 \mathrm{v}$ & $\begin{array}{l}\text { Read M3D13a, John 10:1-9, and/or } \\
\text { M3D13b, which refers the reader to M1D3, } \\
\text { John 10:9-16 }\end{array}$ \\
\hline M8D7b & - & $167 \mathrm{v}$ & Read S2W17D7, Matt. 25:1-13 \\
\hline M8D7c & - & $167 \mathrm{v}$ & Read S3W12D3, Luke 21:12-19 \\
\hline M8D8a & - & $167 \mathrm{v}$ & Read S3W7D7, Luke 9:1-6 \\
\hline M8D8b & - & $167 \mathrm{v}$ & Read M1D3, John 10:9-16 \\
\hline M8D9 & - & $167 \mathrm{v}$ & Read S3W10D7, Luke 10:19-21 \\
\hline M8D10 & - & $167 \mathrm{v}$ & Read S3W5D3, Luke 9:23-27 \\
\hline M8D11 & - & $167 \mathrm{v}$ & $\begin{array}{l}\text { Read M2D3, which refers the reader to read } \\
\text { S2W6D6, Matt. 13:44-54 }\end{array}$ \\
\hline
\end{tabular}




\begin{tabular}{|c|c|c|c|}
\hline Day & Text (written) & Folio & Cross-reference text to locate and read \\
\hline M8D12 & - & $167 \mathrm{v}$ & Read M3D6, Luke 12:8-12 \\
\hline M8D13 & - & $167 \mathrm{v}$ & Read S3W5D3, Luke 9:23-27 \\
\hline M8D14 & - & $167 \mathrm{v}$ & Read M2D18, Luke 10:16-21 \\
\hline M8D15 & - & $167 \mathrm{v}$ & $\begin{array}{l}\text { Read S2W2D1, Matt. 10:32-33, 37-38; } \\
\text { 19:27-30 }\end{array}$ \\
\hline M8D16 & - & $167 \mathrm{v}$ & Read S2W1D3, Matt. 4:23-5:13 \\
\hline M8D17 & - & $167 \mathrm{v}$ & $\begin{array}{l}\text { Read M1D2a which refers the reader to } \\
\text { S1W7D2, John 14:27-15:7, starting at 15:1, } \\
\text { and/or M1D2b, Matt. 5:14-19 }\end{array}$ \\
\hline M8D18 & - & $167 \mathrm{v}$ & $\begin{array}{l}\text { Read S2W4D5, Matt. 11:27-30. (The } \\
\text { evangelist is not specified, but this is the } \\
\text { expected reading in Gregory.) }\end{array}$ \\
\hline M8D19a & - & $168 \mathrm{r}$ & $\begin{array}{l}\text { Read S1W7D2, John 14:27-15:7, } \\
\text { beginning at 15:1: }\end{array}$ \\
\hline M8D19b & - & $168 \mathrm{r}$ & Read S3W5D3, Luke 9:23-27 \\
\hline M8D20 & - & $168 \mathrm{r}$ & $\begin{array}{l}\text { Read M3D5a, Mark 8:34-35; 10:29-31, } \\
\text { and/or M3D5b which refers the reader to } \\
\text { S3W6D1, Luke 16:19-31 }\end{array}$ \\
\hline M8D21a & - & $168 \mathrm{r}$ & Read S4W4D1, Mark 8:34-9:1 \\
\hline M8D21b & - & $168 \mathrm{r}$ & Read S1W7D2, John 15:1-7 \\
\hline M8D22 & - & $168 \mathrm{r}$ & Read S3W2D6, Luke 6:17-23 \\
\hline M8D23a & - & $168 \mathrm{r}$ & Read S1W7D2, John 15:1-7 \\
\hline M8D23b & - & $168 \mathrm{r}$ & Read S1W3D7, John 15:17-16:2 \\
\hline M8D24 & - & $168 \mathrm{r}$ & Read S3W7D6, Luke 12:2-12 \\
\hline M8D25a & - & $168 \mathrm{r}$ & Read M2D18, Luke 10:16-21 \\
\hline M8D25b & - & $168 \mathrm{r}$ & Read S2W15D4, Mark 6:7-13 \\
\hline M8D26 & - & $168 \mathrm{r}$ & Read S1W3D7, John 15:17-16:2 \\
\hline M8D27 & - & $168 \mathrm{r}$ & Read S4W4D1, Mark 8:34-9:1 \\
\hline M8D28 & - & $168 \mathrm{r}$ & Read S3W7D7, Luke 9:1-6 \\
\hline M8D29 & - & $168 \mathrm{r}$ & Read S3W7D6, Luke 12:2-12 \\
\hline M8D30 & - & $168 \mathrm{r}$ & Read M2D9, Matt. 10:1-7, 14-15 \\
\hline M9D1a & - & $168 \mathrm{r}$ & $\begin{array}{l}\text { Read M10D29a which refers the reader to } \\
\text { M2D9, Matt. 10:1-7, 14-15, and/or } \\
\text { M10D29b, Matt. 16:13-19 }\end{array}$ \\
\hline M9D1b & - & $168 \mathrm{r}$ & $\begin{array}{l}\text { Read M10D29a which refers the reader to } \\
\text { M2D9, Matt. 10:1-7, 14-15, and/or } \\
\text { M10D29b, Matt. } 16: 13-19\end{array}$ \\
\hline M9D2 & Matt. 5:14 & $168 \mathrm{r}$ & Read M1D2b, Matt. 5:14-19 \\
\hline M9D3a & - & $168 \mathrm{r}$ & $\begin{array}{l}\text { Read M3D29, Matt. 10:17-18, 23-25, 28- } \\
31\end{array}$ \\
\hline
\end{tabular}




\begin{tabular}{|c|c|c|c|}
\hline Day & Text (written) & Folio & Cross-reference text to locate and read \\
\hline M9D3b & - & $168 \mathrm{r}$ & Read S2W15D2, Mark 5:24-34 \\
\hline M9D4 & - & $168 \mathrm{r}$ & Read S3W12D3, Luke 21:12-19 \\
\hline M9D5 & - & $168 \mathrm{r}$ & Read S2W17D7, Matt. 25:1-13 \\
\hline M9D6 & - & $168 \mathrm{r}$ & Read S2W4D5, Matt. 11:27-30 \\
\hline M9D7a & - & $168 \mathrm{r}$ & $\begin{array}{l}\text { Read M1D13a, John 12:25-36, and/or } \\
\text { M1D13b which refers the reader to } \\
\text { M4D22a/b (references to S2W17D7, Matt. } \\
\text { 25:1-13 and/or S1W5D6, John 10:22-28), } \\
\text { and/or M1D13c which refers the reader to } \\
\text { S5W1D5o, Matt. 27:33-54, and/or } \\
\text { M1D13d which refers to S2W7D7, Matt. } \\
\text { 10:37-11:1, and/or M1D13e, John 3:13-17 }\end{array}$ \\
\hline M9D7b & - & $168 \mathrm{r}$ & Read S1W3D7, John 15:17-16:2 \\
\hline M9D8a & - & $168 \mathrm{r}$ & Read R11, John 21:14-21 (missing) \\
\hline M9D8b & $\begin{array}{l}\text { John 19:25-27; } \\
21: 24-25\end{array}$ & $168 \mathrm{v}$ & \\
\hline M9D8c & - & $168 \mathrm{v}$ & Read S2W4D5, Matt. 11:27-30 \\
\hline M9D9a & - & $168 \mathrm{v}$ & Read S1W6D4, John 12:36-47 \\
\hline M9D9b & - & $168 \mathrm{v}$ & Read S1W7D2, John 15:1-7 \\
\hline M9D10 & - & $168 \mathrm{v}$ & Read M2D9, Matt. 10:1-7, 14-15 \\
\hline M9D11a & - & $168 \mathrm{v}$ & Read S1W3D7, John 15:17-16:2 \\
\hline M9D11b & - & $168 \mathrm{v}$ & $\begin{array}{l}\text { Read a section of S5W1D5i, possibly John } \\
14: 21-24\end{array}$ \\
\hline M9D12 & - & $168 \mathrm{v}$ & $\begin{array}{l}\text { Read M2D11a which refers the reader to } \\
\text { M6D15, Luke 10:3-9, and/or to M2D11b } \\
\text { which refers the reader to M3D6, Luke } \\
\text { 12:8-12, and/or M2D11c which refers the } \\
\text { reader to M1D2b, Matt. 5:14-19, and/or } \\
\text { M2D11d, Mark 13:33-37; 14:3-9, and/or } \\
\text { M2D11e which refers the reader to } \\
\text { S3W5D1, Luke 8:5-15, } 8\end{array}$ \\
\hline M9D13a & - & $168 \mathrm{v}$ & Read S3W17D2, Mark 13:9-13 \\
\hline M9D13b & - & $168 \mathrm{v}$ & Read S2W17D7, Matt. 25:1-13 \\
\hline M9D14 & - & $168 \mathrm{v}$ & Read S3W12D3, Luke 21:12-19 \\
\hline M9D15 & - & $168 \mathrm{v}$ & Read S2W1D3, Matt. 4:23-5:13 \\
\hline M9D16 & - & $168 \mathrm{v}$ & Read S2W11D4, Matt. 23:29-39 \\
\hline M9D17 & - & $168 \mathrm{v}$ & Read S3W7D7, Luke 9:1-6 \\
\hline M9D18 & - & $168 \mathrm{v}$ & Read S2W3D4, Matt. 10:16-22 \\
\hline M9D19 & - & $176 \mathrm{r}$ & Read S3W10D7, Luke 10:19-21 \\
\hline M9D20 & - & $176 \mathrm{r}$ & Read S1W7D2, John 15:1-7 \\
\hline M9D21 & - & $176 \mathrm{r}$ & Read M3D13a, John 10:1-9 \\
\hline M9D22 & - & $176 \mathrm{r}$ & Read S2W3D4, Matt. 10:16-22 \\
\hline
\end{tabular}




\begin{tabular}{|c|c|c|c|}
\hline Day & Text (written) & Folio & Cross-reference text to locate and read \\
\hline M9D23a & - & $176 \mathrm{r}$ & Read M3D6, Luke 12:8-12 \\
\hline M9D23b & - & $176 \mathrm{r}$ & $\begin{array}{l}\text { Read M11D8, Luke 6:17-19, 9:1-2, 10:16- } \\
21\end{array}$ \\
\hline M9D24 & - & $176 \mathrm{r}$ & Read S2W1D3, Matt. 4:23-5:13 \\
\hline M9D25 & - & $176 \mathrm{r}$ & Read S3W3D5, Luke 7:17-30 \\
\hline M9D26 & John $14: 21,24$ & $176 \mathrm{r}$ & Read a section of S5W1D5i, John 14:21-24 \\
\hline M9D27 & - & $176 \mathrm{r}$ & Read M6D23, John 12:24-26, 35-36 \\
\hline M9D28 & - & $176 \mathrm{r}$ & Read S3W7D6, Luke 12:2-12 \\
\hline M9D29 & - & $176 \mathrm{r}$ & Read S2W17D7, Matt. 25:1-13 \\
\hline M9D30 & - & $176 \mathrm{r}$ & Read S2W1D3, Matt. 4:23-5:13 \\
\hline M9D31a & - & $176 \mathrm{r}$ & Read S1W7D2, John 15:1-7 \\
\hline M9D31b & - & $176 \mathrm{r}$ & Read M1D3, John 10:9-16 \\
\hline M10D1 & - & $176 \mathrm{r}$ & Read S2W3D4, Matt. 10:16-22 \\
\hline M10D2 & - & $176 \mathrm{r}$ & Read M1D3, John 10:9-16 \\
\hline M10D3 & - & $176 \mathrm{r}$ & Read S3W10D7, Luke 10:19-21 \\
\hline M10D4 & - & $176 \mathrm{r}$ & Read M1D3, John 10:9-16 \\
\hline M10D5a & Matt. 5:14 & $176 \mathrm{r}$ & Read M1D2b, Matt. 5:14-19 \\
\hline M10D5b & - & $176 \mathrm{r}$ & Read S2W2D5, Matt. 8:23-27 \\
\hline M10D5c & - & $176 \mathrm{r}$ & Read S3W6D3 and S3W6D4, Luke 11:1-13 \\
\hline M10D6a & - & $176 \mathrm{r}$ & Read S3W7D7, Luke 9:1-6 \\
\hline M10D6b & - & $176 \mathrm{r}$ & Read S2W17D7, Matt. 25:1-13 \\
\hline M10D7a & - & $176 \mathrm{r}$ & Read S3W5D6, Luke 10:1-15 \\
\hline M10D7b & - & $176 \mathrm{r}$ & Read M3D6, Luke 12:8-12 \\
\hline M10D8 & - & $176 \mathrm{r}$ & Read S3W10D7, Luke 10:19-21 \\
\hline M10D9a & - & $176 \mathrm{r}$ & $\begin{array}{l}\text { Read M1D2a which refers the reader to } \\
\text { S1W7D2, John 15:1-7, and/or M1D2b, } \\
\text { Matt. 5:14-19 }\end{array}$ \\
\hline M10D9b & - & $176 \mathrm{r}$ & $\begin{array}{l}\text { Read M3D10a which refers the reader to } \\
\text { M4D6 and S3W2D6, Luke 6:17-23, and/or } \\
\text { M3D10b, Luke 14:25-27, 33-35, and/or } \\
\text { M3D10c which refers the reader to } \\
\text { S1W3D7, John 15:17-16:2 }\end{array}$ \\
\hline M10D10a & - & $176 \mathrm{v}$ & Read S3W2D6, Luke 6:17-23 \\
\hline M10D10b & - & $176 \mathrm{v}$ & Read S2W3D4, Matt. 10:16-22 \\
\hline M10D11 & - & $176 v$ & Read S2W15D4, Mark 6:7-13 \\
\hline M10D12a & - & $176 \mathrm{v}$ & Read S2W4D5, Matt. 11:27-30 \\
\hline M10D12b & - & $176 v$ & Read S3W10D7, Luke 10:19-21 \\
\hline M10D13 & - & $176 v$ & Read S2W13D2, Mark 3:6-12 \\
\hline M10D14a & - & $176 \mathrm{v}$ & Read S3W1D6, Luke 4:22-30 \\
\hline M10D14b & - & $176 v$ & Read M1D3, John 10:9-16 \\
\hline
\end{tabular}




\begin{tabular}{|c|c|c|c|}
\hline Day & Text (written) & Folio & Cross-reference text to locate and read \\
\hline M10D15 & - & $176 v$ & Read M4D17, Luke 11:44-50 \\
\hline M10D16 & - & $176 v$ & $\begin{array}{l}\text { Read M3D1a, Matthew reference unclear, } \\
\text { and/or M3D1b, Matt. 10:1-8 }\end{array}$ \\
\hline M10D17 & - & $176 \mathrm{v}$ & Read S3W12D3, Luke 21:12-19 \\
\hline M10D18 & - & $176 \mathrm{v}$ & Read S1W3D7, John 15:17-16:2 \\
\hline M10D19 & $\begin{array}{l}\text { Luke 6:20-26, } \\
10: 23-24,11: 33\end{array}$ & $176 \mathrm{v}$ & \\
\hline M10D20 & - & $169 \mathrm{r}$ & Read S1W3D7, John 15:17-16:2 \\
\hline M10D21 & - & $169 \mathrm{r}$ & Read S3W7D6, Luke 12:2-12 \\
\hline M10D22a & - & $169 \mathrm{r}$ & Read M3D6, Luke 12:8-12 \\
\hline M10D22b & - & $169 \mathrm{r}$ & $\begin{array}{l}\text { Read M3D10a which refers the reader to } \\
\text { M4D6 and S3W2D6, Luke 6:17-23, and/or } \\
\text { M3D10b, Luke 14:25-27, 33-35, and/or } \\
\text { M3D10c which refers the reader to } \\
\text { S1W3D7, John 15:17-16:2 }\end{array}$ \\
\hline M10D23 & - & $169 \mathrm{r}$ & Read S2W15D2, Mark 5:24-34 \\
\hline M10D24a & - & $169 \mathrm{r}$ & Read S3W4D5, Luke 9:7-11 \\
\hline M10D24b & $\begin{array}{l}\text { Luke 1:1-25, 57-68, } \\
76-80\end{array}$ & $169 \mathrm{r}$ & \\
\hline M10D25 & - & $170 \mathrm{v}$ & Read S2W17D7, Matt. 25:1-13 \\
\hline M10D26 & - & $170 \mathrm{v}$ & Read S2W4D5, Matt. 11:27-30 \\
\hline M10D27 & - & $170 \mathrm{v}$ & Read S3W11D7, Luke 12:32-40 \\
\hline M10D28a & - & $170 v$ & $\begin{array}{l}\text { Read M3D1a, Matthew reference unclear, } \\
\text { and/or M3D1b, Matt. 10:1-8 }\end{array}$ \\
\hline M10D28b & - & $170 \mathrm{v}$ & Read S1W3D7, John 15:17-16:2 \\
\hline M10D29a & - & $171 \mathrm{r}$ & Read M2D9, Matt. 10:1-7, 14-15 \\
\hline M10D29b & Matt. 16:13-19 & $171 \mathrm{r}$ & \\
\hline M10D30 & - & $171 \mathrm{r}$ & Read S2W3D5, Matt. 10:23-31 \\
\hline M11D1 & - & $171 \mathrm{r}$ & $\begin{array}{l}\text { Read M3D1a, Matthew reference unclear, } \\
\text { and/or M3D1b, Matt. 10:1-8 }\end{array}$ \\
\hline M11D2 & - & $171 \mathrm{r}$ & Read M1D8a, Luke 1:39-49, 56 \\
\hline M11D3 & - & $171 \mathrm{r}$ & Read S2W3D4, Matt. 10:16-22 \\
\hline M11D4 & Matt. 5:14 & $171 \mathrm{r}$ & Read M1D2b, Matt. 5:14-19 \\
\hline M11D5a & - & $171 \mathrm{v}$ & Read S2W4D5, Matt. 11:27-30 \\
\hline M11D5b & - & $171 \mathrm{v}$ & Read S2W17D7, Matt. 25:1-13 \\
\hline M11D6a & - & $171 \mathrm{v}$ & Read S3W7D6, Luke 12:2-12 \\
\hline M11D6b & - & $171 \mathrm{v}$ & Read S2W17D7, Matt. 25:1-13 \\
\hline M11D6c & - & $171 \mathrm{v}$ & $\begin{array}{l}\text { Read M3D10a which refers the reader to } \\
\text { M4D6 and S3W2D6, Luke 6:17-23, and/or } \\
\text { M3D10b, Luke 14:25-27, 33-35, and/or } \\
\text { M3D10c which refers the reader to } \\
\text { S1W3D7, John 15:17-16:2 }\end{array}$ \\
\hline
\end{tabular}




\begin{tabular}{|c|c|c|c|}
\hline Day & Text (written) & Folio & Cross-reference text to locate and read \\
\hline M11D7a & - & $171 \mathrm{v}$ & Read M6D23, John 12:24-26, 35-36 \\
\hline M11D7b & - & $171 \mathrm{v}$ & Read M2D13, Matt. 7:12-21 \\
\hline M11D8 & $\begin{array}{l}\text { Luke 6:17-19; 9:1- } \\
2 ; 10: 16-21\end{array}$ & $171 \mathrm{v}$ & \\
\hline M11D9a & - & $172 \mathrm{r}$ & Read M2D13, Matt. 7:12-21 \\
\hline M11D9b & - & $172 \mathrm{r}$ & Read S3W12D3, Luke 21:12-19 \\
\hline M11D10 & - & $172 \mathrm{r}$ & Read S2W9D4, Matt. 20:1-16 \\
\hline M11D11 & - & $172 \mathrm{r}$ & Read S3W4D2, Luke 7:36-50 \\
\hline M11D12 & - & $172 \mathrm{r}$ & Read S3W4D2, Luke 7:36-50 \\
\hline M11D13 & - & $172 \mathrm{r}$ & $\begin{array}{l}\text { Read S1W7D7, which refers the reader to } \\
\text { R11, John 21:14-25 (missing) }\end{array}$ \\
\hline M11D14 & - & $172 \mathrm{r}$ & Read M2D18, Luke 10:16-21 \\
\hline M11D15a & - & $172 \mathrm{r}$ & Read S2W10D7, Matt. 17:24-18:4 \\
\hline M11D15b & Matt. 5:14 & $172 \mathrm{r}$ & $\begin{array}{l}\text { Read M1D2b, Matt. 5:14-19, plus extra } \\
\text { instructions }\end{array}$ \\
\hline M11D15c & John $17: 1,21$ & $172 \mathrm{r}$ & $\begin{array}{l}\text { Read John 17:1-21 (no lection number } \\
\text { given) }\end{array}$ \\
\hline M11D16 & - & $172 \mathrm{r}$ & $\begin{array}{l}\text { Read S1W3D7, John 15:17-16:2 (An } \\
\text { alternative lection is offered in the margins } \\
\text { of S5W1D5i, John 17:11-21.) }\end{array}$ \\
\hline M11D17 & - & $172 \mathrm{r}$ & Read S2W17D7, Matt. 25:1-13 \\
\hline M11D18a & - & $172 \mathrm{r}$ & $\begin{array}{l}\text { Read M11D8, Luke 6:17-19; 9:1-2; 10:16- } \\
21\end{array}$ \\
\hline M11D18b & - & $172 \mathrm{v}$ & Read S2W17D7, Matt. 25:1-13 \\
\hline M11D19a & - & $172 \mathrm{v}$ & Read S4W4D1, Mark 8:34-9:1 \\
\hline M11D19b & - & $172 \mathrm{v}$ & Read S2W17D7, Matt. 25:1-13 \\
\hline M11D20a & Matt. 17:5 & $172 \mathrm{v}$ & Read M12D6b, Matt. 17:1-5 \\
\hline M11D20b & Matt. 17:13 & $172 \mathrm{v}$ & Read S2W8D6, Matt. 17:10-13 \\
\hline M11D21a & - & $172 \mathrm{v}$ & $\begin{array}{l}\text { Read M10D19, Luke 6:20-26, 10:23-24, } \\
\text { 11:33 }\end{array}$ \\
\hline M11D21b & - & $172 \mathrm{v}$ & $\begin{array}{l}\text { Read M3D10a which refers the reader to } \\
\text { M4D6 and S3W2D6, Luke 6:17-23, and/or } \\
\text { M3D10b, Luke 14:25-27, 33-35, and/or } \\
\text { M3D10c which refers the reader to } \\
\text { S1W3D7, John 15:17-16:2 }\end{array}$ \\
\hline M11D22a & - & $172 \mathrm{v}$ & Read S3W10D7, Luke 10:19-21 \\
\hline M11D22b & - & $172 \mathrm{v}$ & Read R8, John 20:11-18 (missing) \\
\hline M11D22c & - & $172 \mathrm{v}$ & Read S3W4D3, Luke 8:1-3 \\
\hline M11D23 & - & $172 \mathrm{v}$ & Read S2W3D4, Matt. 10:16-22 \\
\hline M11D24a & - & $172 \mathrm{v}$ & Read S2W17D7, Matt. 25:1-13 \\
\hline
\end{tabular}




\begin{tabular}{|c|c|c|c|}
\hline Day & Text (written) & Folio & Cross-reference text to locate and read \\
\hline M11D24b & - & $172 \mathrm{v}$ & Read S1W3D7, John 15:17-16:2 \\
\hline M11D25a & - & $172 \mathrm{v}$ & Read S3W6D7, Luke 8:16-21 \\
\hline M11D25b & - & $172 \mathrm{v}$ & Read S2W7D7, Matt. 10:37-11:1 \\
\hline M11D26 & - & $172 \mathrm{v}$ & Read S2W1D3, Matt. 4:23-5:13 \\
\hline M11D27 & - & $172 \mathrm{v}$ & Read S1W3D7, John 15:17-16:2 \\
\hline M11D28 & - & $172 \mathrm{v}$ & Read S2W15D4, Mark 6:7-13 \\
\hline M11D29 & - & $172 \mathrm{v}$ & Read S2W3D4, Matt. 10:16-22 \\
\hline M11D30 & - & $172 \mathrm{v}$ & Read S3W7D7, Luke 9:1-6 \\
\hline M11D31a & - & $172 \mathrm{v}$ & Read S3W12D3, Luke 21:12-19 \\
\hline M11D31b & - & $172 \mathrm{v}$ & $\begin{array}{l}\text { Read M3D10a which refers the reader to } \\
\text { M4D6 and S3W2D6, Luke 6:17-23, and/or } \\
\text { M3D10b, Luke 14:25-27, 33-35, and/or } \\
\text { M3D10c which refers the reader to } \\
\text { S1W3D7, John 15:17-16:2 }\end{array}$ \\
\hline M12D1 & - & $172 \mathrm{v}$ & Read S2W3D4, Matt. 10:16-22 \\
\hline M12D2a & - & $172 \mathrm{v}$ & Read S3W11D5, Luke 20:9-18 \\
\hline M12D2b & - & $172 \mathrm{v}$ & Read S2W14D1, Matt. 21:33-42 \\
\hline M12D2c & - & $172 \mathrm{v}$ & Read S3W12D3, Luke 21:12-19 \\
\hline M12D3 & - & $172 \mathrm{v}$ & Read S2W4D5, Matt. 11:27-30 \\
\hline M12D4 & - & $173 \mathrm{r}$ & Read S3W4D3, Luke 8:1-3 \\
\hline M12D5a & - & $173 \mathrm{r}$ & Read S4W4D1, Mark 8:34-9:1 \\
\hline M12D5b & - & $173 \mathrm{r}$ & Uncertain Sabbath reading in Matthew \\
\hline M12D6a & Luke 9:28-36 & $173 \mathrm{r}$ & \\
\hline M12D6b & Matt. 17:1-9 & $173 v$ & \\
\hline M12D7 & Mark 9:2-9 & $174 \mathrm{r}$ & \\
\hline M12D8 & - & $174 \mathrm{v}$ & Read S4W4D1, Mark 8:34-9:1 \\
\hline M12D9 & - & $174 \mathrm{v}$ & Read S2W15D4, Mark 6:7-13 \\
\hline M12D10 & - & $174 \mathrm{v}$ & Read S1W3D7, John 15:17-16:2 \\
\hline M12D11 & - & $174 \mathrm{v}$ & Read M6D23, John 12:24-26, 35-36 \\
\hline M12D12 & - & $174 \mathrm{v}$ & Read S3W7D7, Luke 9:1-6 \\
\hline M12D13 & - & $174 \mathrm{v}$ & Read M3D6, Luke 12:8-12 \\
\hline M12D14 & - & $174 \mathrm{v}$ & Read S3W11D7, Luke 12:32-40 \\
\hline M12D15 & - & $174 \mathrm{v}$ & $\begin{array}{l}\text { Read M1D8a and b, Luke 1:39-49, } 56 \text { and } \\
\text { Luke 10:38-42; 11:27-28 }\end{array}$ \\
\hline M12D16 & John 15:1 & $174 \mathrm{v}$ & Read S1W7D2, John 15:1-7 \\
\hline M12D17 & - & $174 \mathrm{v}$ & Read S3W2D3, Luke 5:12-16 \\
\hline M12D18 & - & $174 \mathrm{v}$ & Read S3W7D6, Luke 12:2-12 \\
\hline M12D19 & - & $174 \mathrm{v}$ & Read S1W7D2, John 15:1-7 \\
\hline M12D20a & - & $174 \mathrm{v}$ & Read M2D9, Matt. 10:1-7, 14-15 \\
\hline M12D20b & - & $174 \mathrm{v}$ & $\begin{array}{l}\text { Read M10D29a which refers the reader to } \\
\text { M2D9, Matt. 10:1-7, 14-15, and/or } \\
\text { M10D29b, Matt. 16:13-19 }\end{array}$ \\
\hline
\end{tabular}




\begin{tabular}{|c|c|c|c|}
\hline Day & Text (written) & Folio & Cross-reference text to locate and read \\
\hline M12D21a & - & $174 \mathrm{v}$ & Read S2W10D7, Matt. 17:24-18:4 \\
\hline M12D21b & - & $174 \mathrm{v}$ & Read S2W17D7, Matt. 25:1-13 \\
\hline M12D22 & - & $174 \mathrm{v}$ & Read S1W3D7, John 15:17-16:2 \\
\hline M12D23 & - & $174 \mathrm{v}$ & Read S1W7D2, John 15:1-7 \\
\hline M12D24 & - & $174 \mathrm{v}$ & Read M2D9, Matt. 10:1-7, 14-15 \\
\hline M12D25 & - & $174 \mathrm{v}$ & $\begin{array}{l}\text { Read M1D2a which refers the reader to } \\
\text { S1W7D2, John 15:1-7, and/or M1D2b, } \\
\text { Matt. 5:14-19 }\end{array}$ \\
\hline M12D26 & - & $174 \mathrm{v}$ & Read S3W12D3, Luke 21:12-19 \\
\hline M12D27 & - & $175 \mathrm{r}$ & Read S3W2D6, Luke 6:17-23 \\
\hline M12D28 & - & $175 \mathrm{r}$ & Read S2W4D5, Matt. 11:27-30 \\
\hline M12D29a & - & $175 \mathrm{r}$ & Read S2W7D3, Matt. 14:1-13 \\
\hline M12D29b & Mark 6:14-30 & $175 \mathrm{r}$ & \\
\hline M12D30 & - & $175 \mathrm{v}$ & $\begin{array}{l}\text { Read M1D2a which refers the reader to } \\
\text { S1W7D2, John 15:1-7, and/or M1D2b, } \\
\text { Matt. 5:14-19 }\end{array}$ \\
\hline M12D31 & - & $175 \mathrm{v}$ & $\begin{array}{l}\text { Read M11D2, which refers the reader to } \\
\text { read M1D8a, Luke } 1: 39-49,56\end{array}$ \\
\hline
\end{tabular}




\section{LIST: COMMEMORATIONS AND RUBRICS IN THE MENOLOGION OF CODEX ZACYNTHIUS}

Days with multiple readings have their headings combined for each day, except where moveable feasts interrupt a day's lections and the order of the manuscript is retained. Commemorations with additional prokeimena and stichoi are in bold. Separate readings for Matins and Liturgy are noted in square brackets.

\begin{tabular}{|c|c|c|}
\hline Day & Heading & Commemoration \\
\hline Sept. 1 & 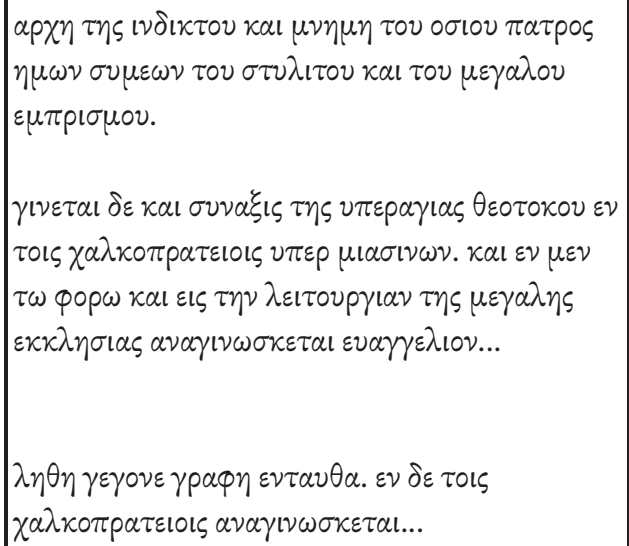 & $\begin{array}{l}\text { Beginning of the Indiction }{ }^{1} \text { and } \\
\text { commemoration of our holy father Simeon } \\
\text { Stylites, and of the Great Fire. } \\
\text { The service of the all-holy Mother of God } \\
\text { takes place in the Chalkoprateia Monastery } \\
\text { above Miasenoi, and also in the Forum, and } \\
\text { in the Liturgy of the Great Church is read } \\
\text { the Gospel... } \\
\text { Next, the scripture has been passed over. In } \\
\text { the Chalkoprateia is read... }\end{array}$ \\
\hline Sept. 2 & 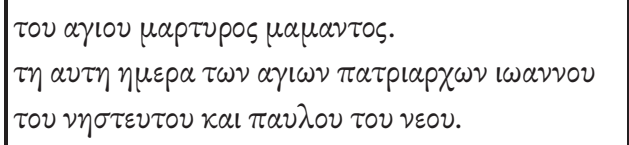 & $\begin{array}{l}\text { St Mamas the martyr. } \\
\text { On the same day the Patriarchs St John the } \\
\text { Faster and St Paul the Younger. }\end{array}$ \\
\hline Sept. 3 & 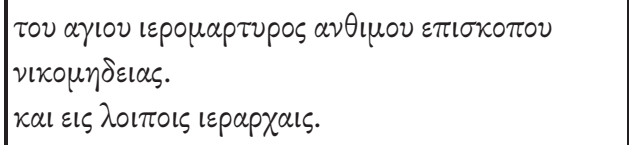 & $\begin{array}{l}\text { St Anthimus the Hieromartyr, bishop of } \\
\text { Nicomedia. } \\
\text { And the other high-priests. }\end{array}$ \\
\hline Sept. 4 & 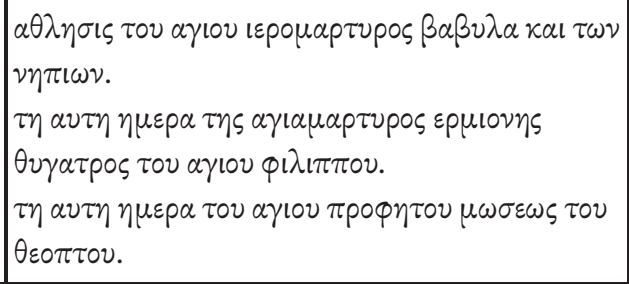 & $\begin{array}{l}\text { The trial of St Babylas the Hieromartyr and } \\
\text { children. } \\
\text { On the same day the holy martyr } \\
\text { Hermione, daughter of St Philip. } \\
\text { On the same day the holy Prophet and } \\
\text { God-seer Moses. }\end{array}$ \\
\hline Sept. 5 & 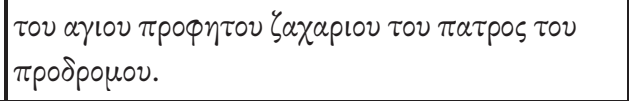 & $\begin{array}{l}\text { The sainted Prophet Zechariah, father of } \\
\text { the Forerunner. }\end{array}$ \\
\hline Sept. 6 & 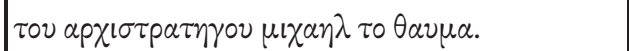 & The miracle of the Archangel Michael. \\
\hline
\end{tabular}

\footnotetext{
${ }^{1}$ This indicates the beginning of the Church Year.

${ }^{2}$ The Great Fire of Constantinople began on 1 September 465. 


\begin{tabular}{|c|c|c|}
\hline Day & Heading & Commemoration \\
\hline & 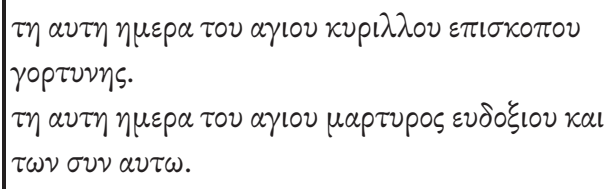 & $\begin{array}{l}\text { On the same day St Cyril, bishop of } \\
\text { Gortyna. } \\
\text { On the same day St Eudoxius the Martyr } \\
\text { and those with him. }\end{array}$ \\
\hline Sept. 7 & 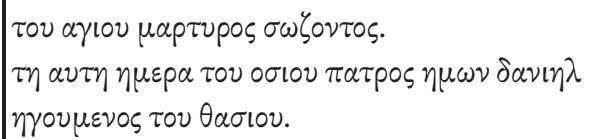 & $\begin{array}{l}\text { St Sozon the martyr. } \\
\text { On the same day our holy father Daniel, } \\
\text { abbot of Thasos. }\end{array}$ \\
\hline Sept. 8 & 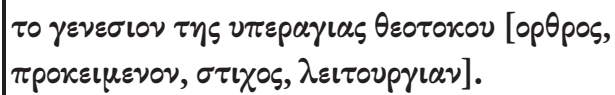 & $\begin{array}{l}\text { The birth of the most-holy Mother of } \\
\text { God. }\end{array}$ \\
\hline Sept. 9 & $\tau \omega \nu \alpha \gamma l \omega \nu$ Kal $\delta l \kappa \alpha l \omega \nu l \omega \alpha \kappa \varepsilon l \mu$ Kal $\alpha \nu \nu \eta \zeta$. & $\begin{array}{l}\text { The sainted and righteous Joachim and } \\
\text { Anna. }\end{array}$ \\
\hline Sept. 10 & 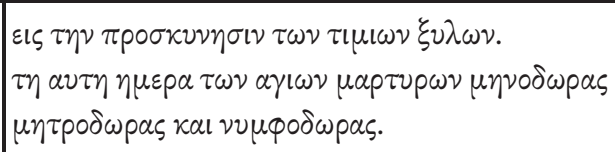 & $\begin{array}{l}\text { For the adoration of the precious wood. }{ }^{3} \\
\text { On the same day the martyrs St Menadora, } \\
\text { Metrodora and Nymphodora. }\end{array}$ \\
\hline Sept. 11 & 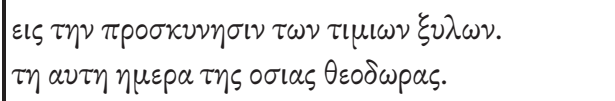 & $\begin{array}{l}\text { For the adoration of the precious wood. } \\
\text { On the same day St Theodora. }\end{array}$ \\
\hline Sept. 12 & 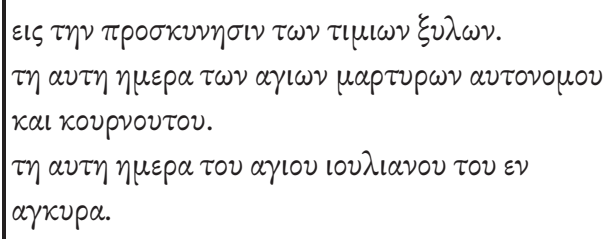 & $\begin{array}{l}\text { For the adoration of the precious wood. } \\
\text { On the same day the martyrs St } \\
\text { Autonomus and Coronatus. } \\
\text { On the same day St Julian of Ancyra. }\end{array}$ \\
\hline \multirow[t]{3}{*}{ Sept. 13} & 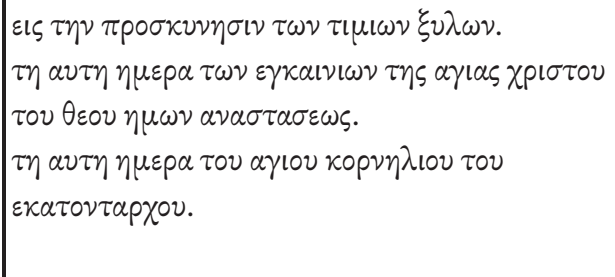 & $\begin{array}{l}\text { For the adoration of the precious wood. } \\
\text { On the same day the Dedication of the } \\
\text { Church of the Holy Resurrection of Christ } \\
\text { our God }{ }^{4} \text {. } \\
\text { On the same day St Cornelius the } \\
\text { centurion. }\end{array}$ \\
\hline & 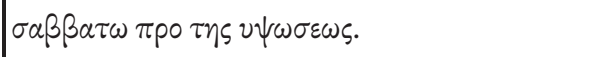 & Saturday before the Elevation. \\
\hline & 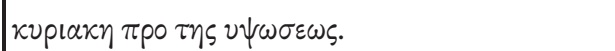 & Sunday before the Elevation. \\
\hline
\end{tabular}

\footnotetext{
${ }^{3}$ The reference is to the anticipation of Holy Cross Day on September 14th.

${ }^{4}$ This is the Church of the Holy Sepulchre at Jerusalem.
} 


\begin{tabular}{|c|c|c|}
\hline Day & Heading & Commemoration \\
\hline \multirow[t]{3}{*}{$\begin{array}{l}\text { Sept. } \\
14\end{array}$} & 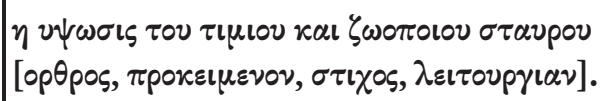 & $\begin{array}{l}\text { Elevation of the precious and life-giving } \\
\text { Cross. }\end{array}$ \\
\hline & $\sigma \alpha \beta \beta \alpha \tau \omega \mu \varepsilon \tau \alpha \tau \eta \nu \nu \psi \omega \sigma \tau \nu$. & Saturday after the Elevation. \\
\hline & 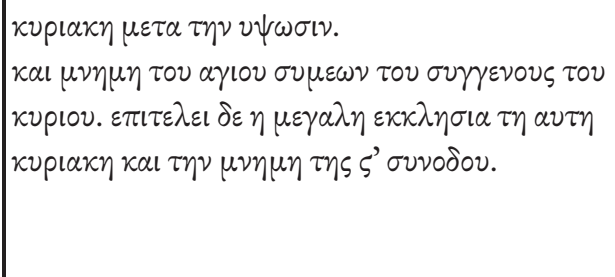 & $\begin{array}{l}\text { Sunday after the Elevation. } \\
\text { Also memorial of St Simeon kinsman of the } \\
\text { Lord. } \\
\text { The Great Church also celebrates on this } \\
\text { Sunday the commemoration of the 6th } \\
\text { Synod. }\end{array}$ \\
\hline Sept. 15 & 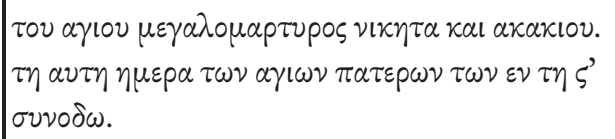 & $\begin{array}{l}\text { St Nicetas the great martyr and Acacius. } \\
\text { On the same day the sainted fathers of the } \\
\text { 6th Synod. }\end{array}$ \\
\hline Sept. 16 & 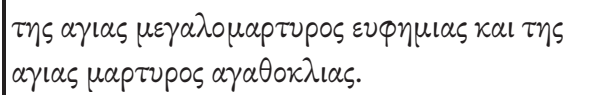 & $\begin{array}{l}\text { St Euphemia the Great Martyr and St } \\
\text { Agathocleia the holy martyr. }\end{array}$ \\
\hline Sept. 17 & 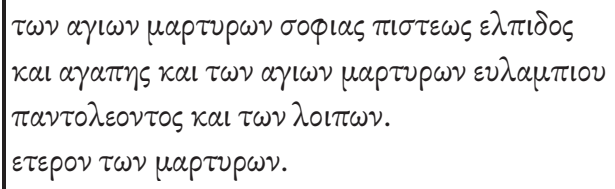 & $\begin{array}{l}\text { The martyrs St Sophia, Pistis, Elpis and } \\
\text { Agape, and the martyrs St Eulampius, } \\
\text { Pantaleon and the others. } \\
\text { An alternative for martyrs. }\end{array}$ \\
\hline Sept. 18 & 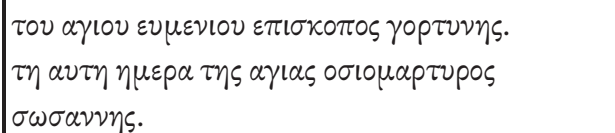 & $\begin{array}{l}\text { St Eumenius, Bishop of Gortyna. } \\
\text { On the same day St Susanna the blessed } \\
\text { martyr. }\end{array}$ \\
\hline Sept. 19 & 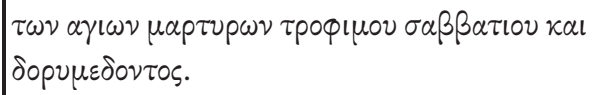 & $\begin{array}{l}\text { The martyrs St Trophimus, Sabbatius and } \\
\text { Dorymedon. }\end{array}$ \\
\hline Sept. 20 & $\begin{array}{l}\tau \circ v \alpha \gamma 10 v \mu \varepsilon \gamma \alpha \lambda \circ \mu \alpha \rho \tau \nu \rho \circ \varsigma \varepsilon v \sigma \tau \alpha \theta 10 \nu \text { kal } \tau \omega \nu \\
\sigma \nu \nu \alpha \nu \tau \omega .\end{array}$ & $\begin{array}{l}\text { St Eustathius the Great Martyr and those } \\
\text { with him. }\end{array}$ \\
\hline Sept. 21 & 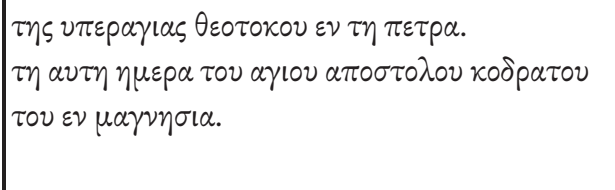 & $\begin{array}{l}\text { The church of the most holy Mother of } \\
\text { God in Petra. } \\
\text { On the same day St Quadratus the Apostle } \\
\text { in Magnesia. }\end{array}$ \\
\hline Sept. 22 & 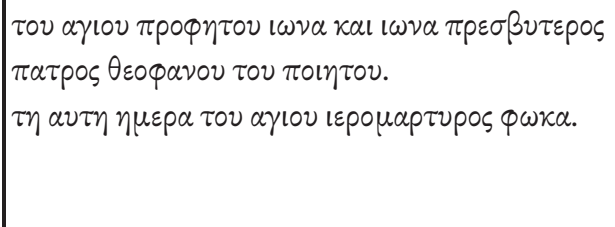 & $\begin{array}{l}\text { The sainted prophet Jonah and Jonah the } \\
\text { priest, father of Theophanes the } \\
\text { hymnographer. } \\
\text { On the same day the St Phocas the } \\
\text { Hieromartyr. }\end{array}$ \\
\hline Sept. 23 & 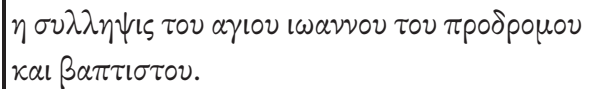 & $\begin{array}{l}\text { The Conception of St John the Forerunner } \\
\text { and Baptist. }\end{array}$ \\
\hline
\end{tabular}




\begin{tabular}{|c|c|c|}
\hline Day & Heading & Commemoration \\
\hline Sept. 24 & 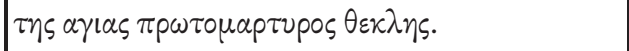 & St Thekla the Protomartyr. \\
\hline Sept. 25 & 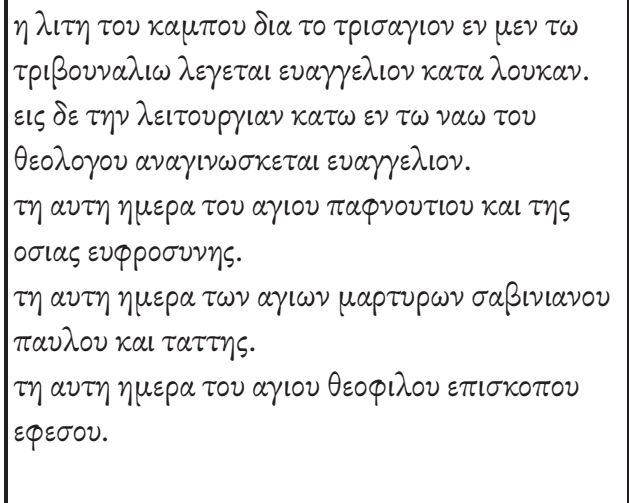 & $\begin{array}{l}\text { In the Litany of the Kampos during the } \\
\text { Trisagion in the Tribunal is read the Gospel } \\
\text { of Luke. } \\
\text { In the liturgy below in the Church of the } \\
\text { Theologian is read the Gospel. } \\
\text { On the same day St Paphnutius and the } \\
\text { holy Euphrosyne. } \\
\text { On the same day the martyrs St Sabinian, } \\
\text { Paul and Tatta. } \\
\text { On the same day St Theophilos, Bishop of } \\
\text { Ephesus. }\end{array}$ \\
\hline Sept. 26 & 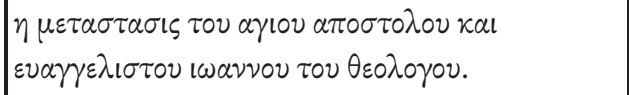 & $\begin{array}{l}\text { The Repose of the Apostle and Evangelist } \\
\text { St John the Theologian. }\end{array}$ \\
\hline Sept. 27 & 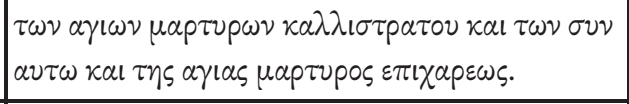 & $\begin{array}{l}\text { The martyrs St Callistratus and those with } \\
\text { him and St Epicharis the Martyr. }\end{array}$ \\
\hline Sept. 28 & 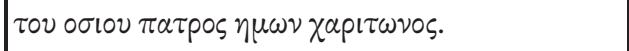 & Our holy father Chariton. \\
\hline Sept. 29 & 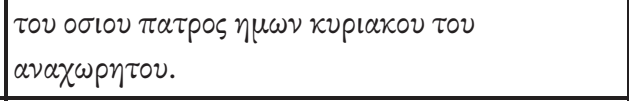 & Our holy father Cyriacus the anchorite. \\
\hline Sept. 30 & 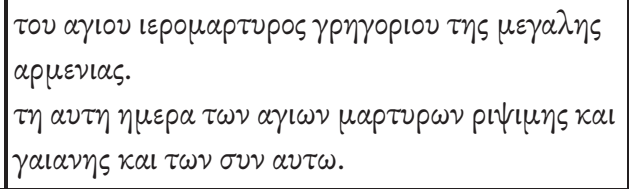 & $\begin{array}{l}\text { The Hieromartyr St Gregory of Greater } \\
\text { Armenia. } \\
\text { On the same day the martyrs St Rhipsima } \\
\text { and Gaiana and those with them. }\end{array}$ \\
\hline Oct. 1 & 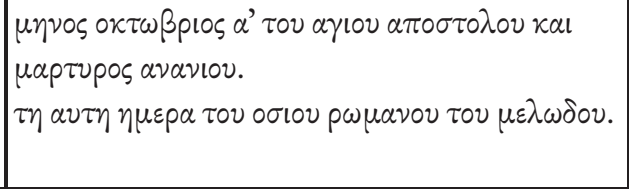 & $\begin{array}{l}\text { October 1, the Apostle and martyr St } \\
\text { Ananias. } \\
\text { On the same day the holy Romanos the } \\
\text { Melodist. }\end{array}$ \\
\hline Oct. 2 & 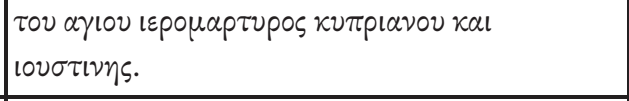 & St Cyprian the Hieromartyr and Justina. \\
\hline Oct. 3 & 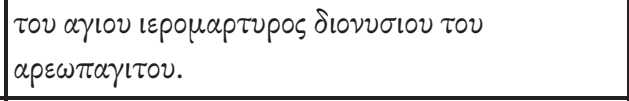 & $\begin{array}{l}\text { St Dionysius the Areopagite, the } \\
\text { Hieromartyr. }\end{array}$ \\
\hline Oct. 4 & 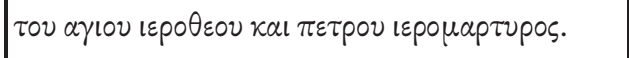 & St Hierotheus and the Hieromartyr Peter. \\
\hline Oct. 5 & 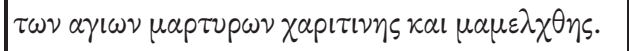 & The martyrs St Charitina and Mamelchtha. \\
\hline
\end{tabular}

\footnotetext{
${ }^{5}$ This refers to a processional liturgy.
} 


\begin{tabular}{|c|c|c|}
\hline Day & Heading & Commemoration \\
\hline Oct. 6 & $\tau \circ \nu \alpha \gamma 10 \nu \alpha \pi \circ \sigma \tau 0 \lambda \circ \nu \theta \omega \mu \alpha$ & St Thomas the Apostle. \\
\hline Oct. 7 & 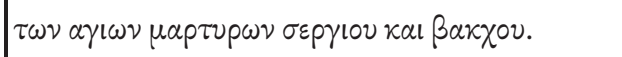 & The martyrs St Sergius and Bacchus. \\
\hline Oct. 8 & $\tau \eta \varsigma \alpha \gamma l \alpha \varsigma \pi \varepsilon \lambda \alpha \gamma / \alpha \varsigma$ & St Pelagia. \\
\hline Oct. 9 & 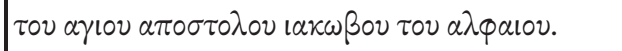 & St James the Apostle, son of Alphaeus. \\
\hline Oct. 10 & $\tau \omega \nu \alpha \gamma l \omega \nu \mu \alpha \rho \tau \nu \rho \omega \nu \varepsilon \nu \lambda \alpha \mu \pi i \circ \nu$ kal $\varepsilon \nu \lambda \alpha \mu \pi l \alpha \zeta$ & St Eulampius and Eulampia the martyrs. \\
\hline \multirow[t]{2}{*}{ Oct. 11} & 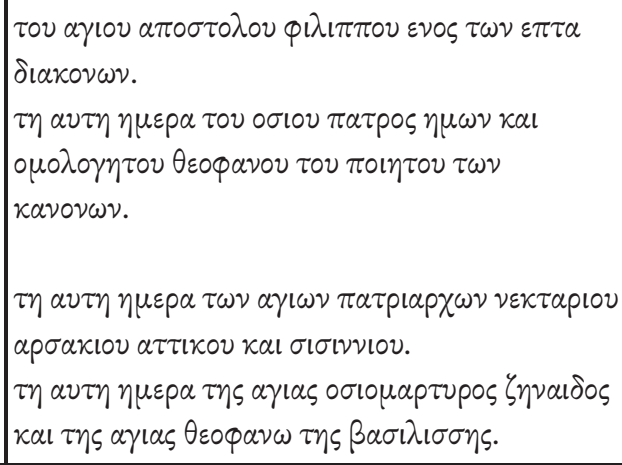 & $\begin{array}{l}\text { St Philip the Apostle, one of the seven } \\
\text { deacons. } \\
\text { On the same day our holy father and } \\
\text { confessor Theophanes the writer of the } \\
\text { canons. } \\
\text { On the same day the Patriarchs St } \\
\text { Nectarius, Arsacius, Atticus and Sisinnius. } \\
\text { On the same day the Hieromartyr St Zenais } \\
\text { and St Theophanou the empress. }\end{array}$ \\
\hline & 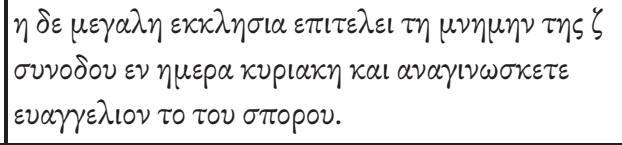 & $\begin{array}{l}\text { The Great Church celebrates the memorial } \\
\text { of the Seventh Synod on Sunday, and the } \\
\text { gospel of the sowing is read. }\end{array}$ \\
\hline Oct. 12 & 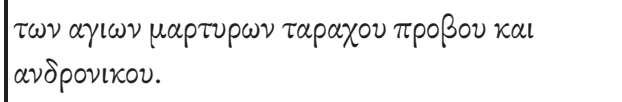 & $\begin{array}{l}\text { The martyrs St Tarachus, Probus and } \\
\text { Andronicus. }\end{array}$ \\
\hline Oct. 13 & 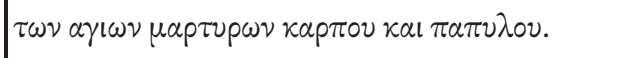 & The martyrs St Carpus and Papylus. \\
\hline Oct. 14 & $\begin{array}{l}\tau \omega \nu \alpha \gamma i \omega \nu \mu \alpha \rho \tau \nu \rho \omega \nu \nu \alpha \zeta \alpha \rho 10 \nu \\
\tau \omega \nu \rho \beta \alpha \sigma 10 \nu \\
\tau \omega \nu \alpha \nu \\
\end{array}$ & $\begin{array}{l}\text { The martyrs St Nazarius, Gervasius and } \\
\text { those with him. }\end{array}$ \\
\hline Oct. 15 & 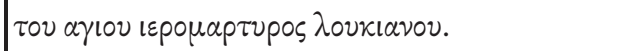 & St Lucian the Hieromartyr. \\
\hline Oct. 16 & 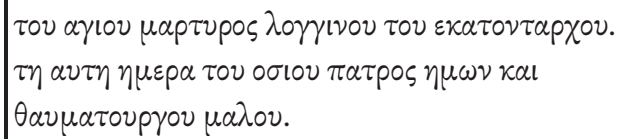 & $\begin{array}{l}\text { St Longinus the centurion and martyr. } \\
\text { On the same day our holy father and } \\
\text { wonderworker Malus. }\end{array}$ \\
\hline Oct. 17 & 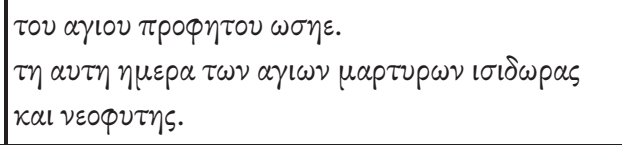 & $\begin{array}{l}\text { The sainted Prophet Hosea. } \\
\text { On the same day the martyrs St Isidora and } \\
\text { Neophyte. }\end{array}$ \\
\hline Oct. 18 & 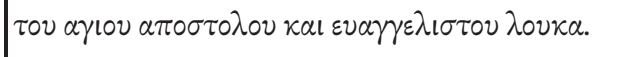 & St Luke the apostle and evangelist. \\
\hline Oct. 19 & 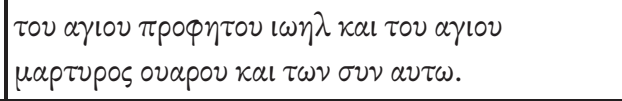 & $\begin{array}{l}\text { The sainted Prophet Joel and St Varus the } \\
\text { Martyr and those with him. }\end{array}$ \\
\hline Oct. 20 & 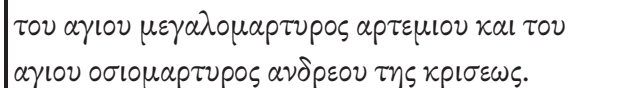 & $\begin{array}{l}\text { St Artemius the Great Martyrand St } \\
\text { Andrew of Crete the Hieromartyr. }\end{array}$ \\
\hline
\end{tabular}




\begin{tabular}{|c|c|c|}
\hline Day & Heading & Commemoration \\
\hline Oct. 21 & 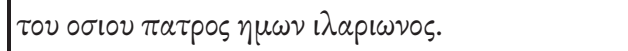 & Our holy father Hilarion. \\
\hline Oct. 22 & 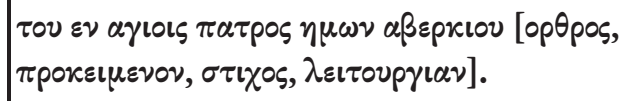 & Our father Abercius among the saints. ${ }^{6}$ \\
\hline Oct. 23 & 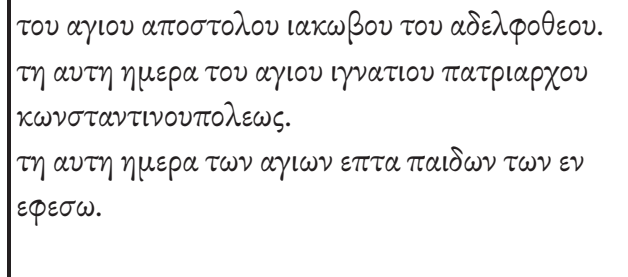 & $\begin{array}{l}\text { St James the Apostle, the brother of the } \\
\text { Lord. } \\
\text { On the same day St Ignatius, Patriarch of } \\
\text { Constantinople. } \\
\text { On the same day the seven sainted children } \\
\text { in Ephesus. }\end{array}$ \\
\hline Oct. 24 & 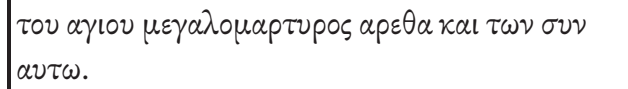 & $\begin{array}{l}\text { St Arethas the great martyr and those with } \\
\text { him. }\end{array}$ \\
\hline Oct. 25 & 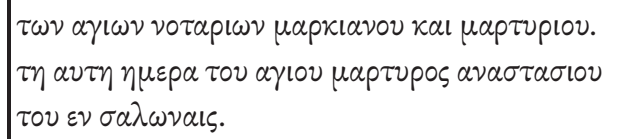 & $\begin{array}{l}\text { St Marcian and Martyrius the notaries. } \\
\text { On the same day St Anastasius the Martyr } \\
\text { of Salona. }\end{array}$ \\
\hline Oct. 26 & 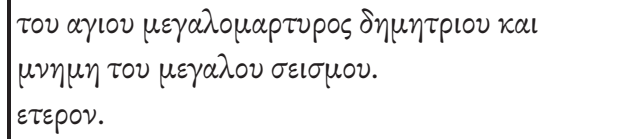 & $\begin{array}{l}\text { St Demetrius the Great Martyr and the } \\
\text { commemoration of the Great Earthquake. } \\
\text { An alternative. }\end{array}$ \\
\hline Oct. 27 & 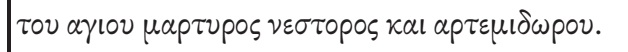 & St Nestor the Martyr and Artemidorus \\
\hline Oct. 28 & 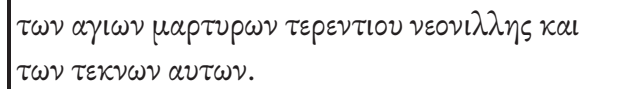 & $\begin{array}{l}\text { The martyrs St Terence, Neonilla and their } \\
\text { children. }\end{array}$ \\
\hline Oct. 29 & 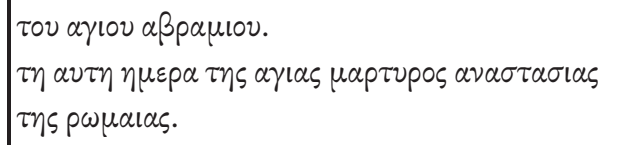 & $\begin{array}{l}\text { St Abramius. } \\
\text { On the same day St Anastasia the Roman } \\
\text { martyr. }\end{array}$ \\
\hline Oct. 30 & 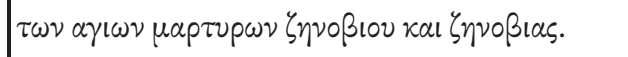 & St Zenobius and Zenobia the martyrs. \\
\hline Oct. 31 & 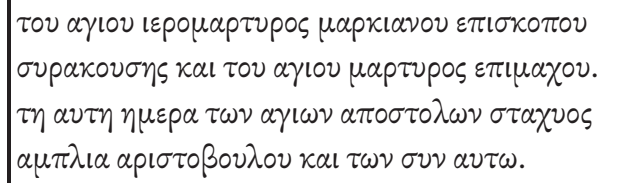 & $\begin{array}{l}\text { St Marcian the Hieromartyr, Bishop of } \\
\text { Syracuse, and St Epimachus the Martyr. } \\
\text { On the same day the apostles St Stachys, } \\
\text { Amplias, Aristobulus and those with him. }\end{array}$ \\
\hline Nov. 1 & 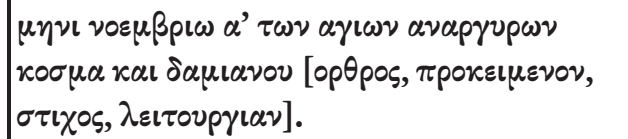 & $\begin{array}{l}\text { November 1. St Cosmas and Damian } \\
\text { the Unmercenaries. }\end{array}$ \\
\hline
\end{tabular}

\footnotetext{
${ }^{6}$ Bishop of Hierapolis.

${ }^{7}$ The Great Earthquake of Constantinople took place in $740 \mathrm{AD}$.

${ }^{8}$ The term 'unmercenary' refers to physicians who refused payment for their services.
} 


\begin{tabular}{|c|c|c|}
\hline Day & Heading & Commemoration \\
\hline Nov. 2 & 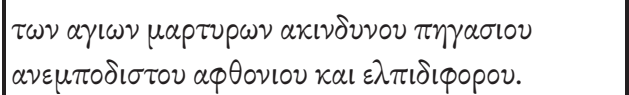 & $\begin{array}{l}\text { St Acindynus, Pegasius, Anempodistus, } \\
\text { Aphthonius and Elpidephorus the martyrs. }\end{array}$ \\
\hline Nov. 3 & 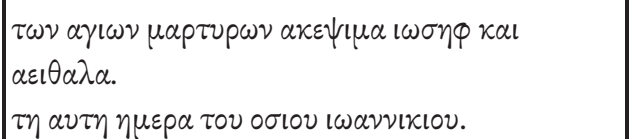 & $\begin{array}{l}\text { St Acepsimas, Joseph and Aeithalas the } \\
\text { martyrs. } \\
\text { On the same day the holy Joannicius. }\end{array}$ \\
\hline Nov. 4 & 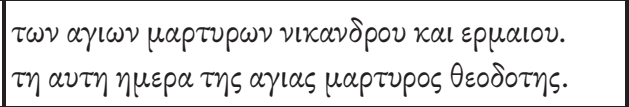 & $\begin{array}{l}\text { St Nicander and Hermas the martyrs. } \\
\text { On the same day St Theodota the Martyr. }\end{array}$ \\
\hline \multirow[t]{2}{*}{ Nov. 5} & $\begin{array}{l}\tau \omega \nu \alpha \gamma i \omega \nu \mu \alpha \rho \tau \nu \rho \omega \nu \gamma \alpha \lambda \alpha \alpha \kappa \tau l \omega \nu \circ \sigma \alpha \alpha l \\
\varepsilon \pi i \sigma \tau \eta \mu \eta \varsigma .\end{array}$ & St Galacteon and Episteme the martyrs. \\
\hline & 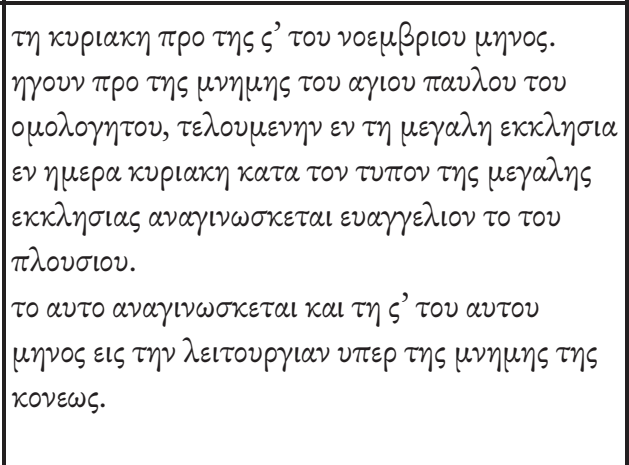 & $\begin{array}{l}\text { On the Sunday before November 6, before } \\
\text { the commemoration of St Paul the } \\
\text { Confessor, in the Great Church on Sunday } \\
\text { according to the rite of the Great Church, is } \\
\text { read the Gospel of the Rich Man. } \\
\text { The same is read also on the 6th of the same } \\
\text { month in the liturgy for the } \\
\text { commemoration of the Rain of Cinders.' }\end{array}$ \\
\hline Nov. 6 & 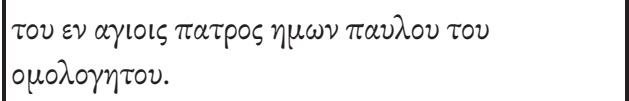 & $\begin{array}{l}\text { Our father Paul the confessor among the } \\
\text { saints. }\end{array}$ \\
\hline Nov. 7 & $\begin{array}{l}\tau \omega \nu \alpha \gamma / \omega \nu \lambda \gamma^{\prime} \mu \alpha \rho \tau \nu \rho \omega \nu \tau \omega \nu \varepsilon \nu \mu \varepsilon \lambda \varepsilon \tau i \nu \eta . \\
\tau \eta \alpha \nu \tau \eta \eta\end{array}$ & $\begin{array}{l}\text { The } 33 \text { martyrs of Melitene. } \\
\text { On the same day the holy Matrona. }\end{array}$ \\
\hline Nov. 8 & 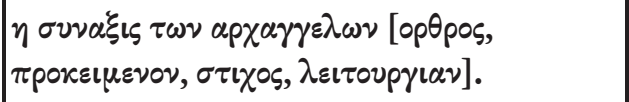 & The celebration of the archangels. \\
\hline Nov. 9 & 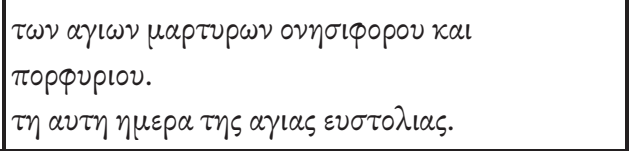 & $\begin{array}{l}\text { St Onesiphorus and Porphyrius the } \\
\text { martyrs. } \\
\text { On the same day St Eustolia. }\end{array}$ \\
\hline Nov. 10 & 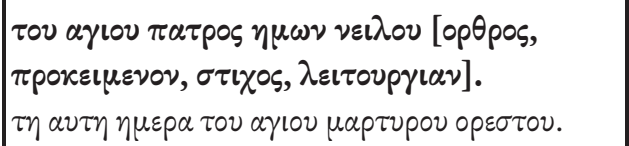 & $\begin{array}{l}\text { Our father St Neilus. } \\
\text { On the same day St Orestes the Martyr. }\end{array}$ \\
\hline Nov. 11 & 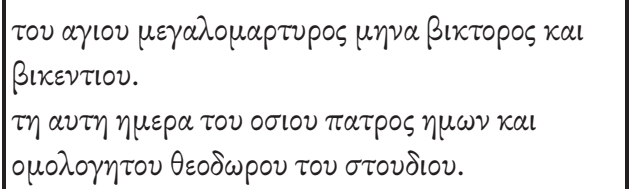 & $\begin{array}{l}\text { St Menas the Great Martyr, Victor and } \\
\text { Vincent. } \\
\text { On the same day our holy father and } \\
\text { confessor Theodore the Studite. }\end{array}$ \\
\hline Nov. 12 & 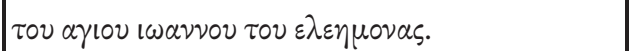 & St John the Almsgiver. \\
\hline
\end{tabular}

${ }^{9}$ The Rain of Cinders took place in $472 \mathrm{AD}$. 


\begin{tabular}{|c|c|c|}
\hline Day & Heading & Commemoration \\
\hline & 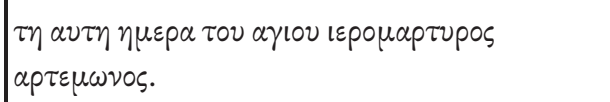 & $\begin{array}{l}\text { On the same day St Artemon the } \\
\text { Hieromartyr. }\end{array}$ \\
\hline Nov. 13 & 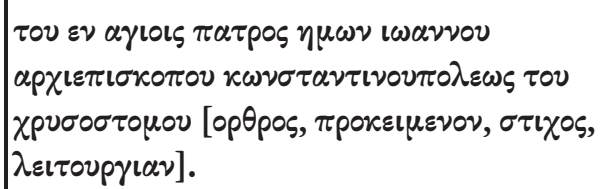 & $\begin{array}{l}\text { Our father among the saints John } \\
\text { Chrysostom, Archbishop of } \\
\text { Constantinople. }\end{array}$ \\
\hline Nov. 14 & 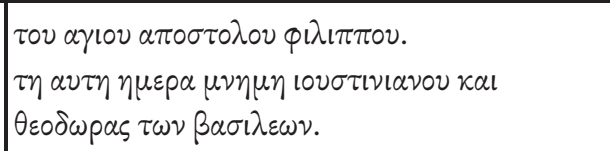 & $\begin{array}{l}\text { St Philip the Apostle. } \\
\text { On the same day the commemoration of } \\
\text { the emperors Justinian and Theodora. }\end{array}$ \\
\hline Nov. 15 & 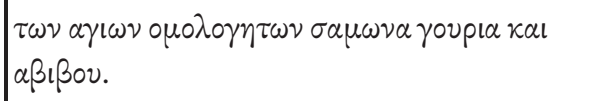 & $\begin{array}{l}\text { St Samonas, Gurias and Abibus the } \\
\text { confessors. }\end{array}$ \\
\hline Nov. 16 & 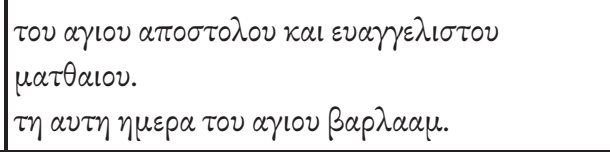 & $\begin{array}{l}\text { St Matthew, Apostle and Evangelist. } \\
\text { On the same day St Barlaam. }\end{array}$ \\
\hline Nov. 17 & 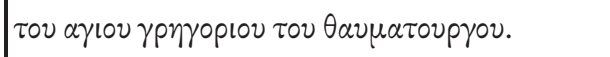 & St Gregory the Wonderworker. \\
\hline Nov. 18 & $\tau \omega \nu \alpha \gamma l \omega \nu \mu \alpha \rho \tau \nu \rho \omega \nu \pi \lambda \alpha \tau \omega \nu \circ \sigma^{2} \kappa \alpha l \rho \omega \mu \alpha \nu \circ \nu$. & St Platon and Romanus the martyrs. \\
\hline Nov. 19 & 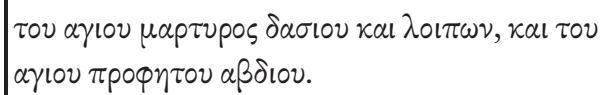 & $\begin{array}{l}\text { St Dasius the Martyr and the others, and } \\
\text { the holy prophet Obadiah. }\end{array}$ \\
\hline Nov. 20 & 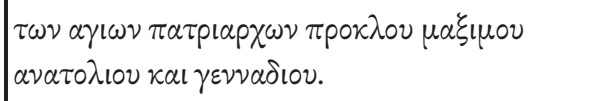 & $\begin{array}{l}\text { St Proclus, Maximus, Anatolius and } \\
\text { Gennadius the Patriarchs. }\end{array}$ \\
\hline Nov. 21 & 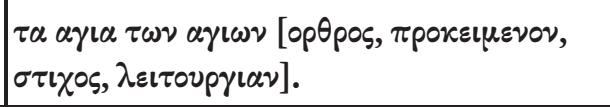 & The Holy of Holies. ${ }^{10}$ \\
\hline Nov. 22 & 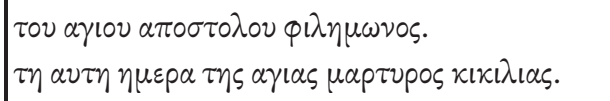 & $\begin{array}{l}\text { St Philemon the Apostle. } \\
\text { On the same day St Cecilia the Martyr. }\end{array}$ \\
\hline Nov. 23 & 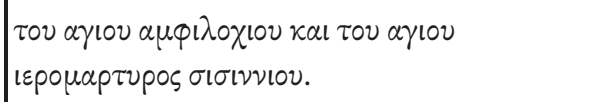 & $\begin{array}{l}\text { St Amphilochius and St Sisinius the } \\
\text { Hieromartyr. }\end{array}$ \\
\hline Nov. 24 & 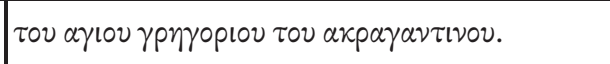 & St Gregory of Agrigentum. \\
\hline Nov. 25 & 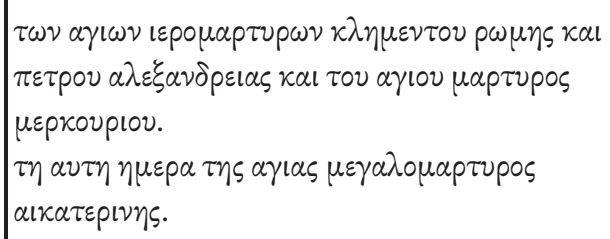 & $\begin{array}{l}\text { St Clement of Rome and Peter of } \\
\text { Alexandria the Hieromartyrs, and St } \\
\text { Mercurius the Martyr. } \\
\text { On the same day St Catherine the Great } \\
\text { Martyr. }\end{array}$ \\
\hline
\end{tabular}

\footnotetext{
${ }^{10}$ Feast of the Dedication of the Theotokos in the Temple.
} 


\begin{tabular}{|c|c|c|}
\hline Day & Heading & Commemoration \\
\hline Nov. 26 & 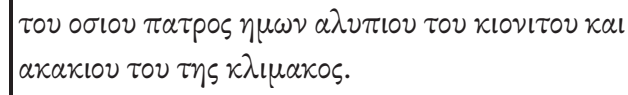 & $\begin{array}{l}\text { Our holy father Alypius the Stylite and } \\
\text { Acacius of the Ladder. }\end{array}$ \\
\hline Nov. 27 & 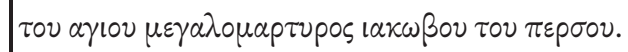 & St James of Persia the Great Martyr. \\
\hline Nov. 28 & 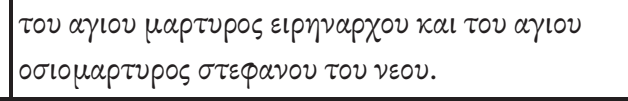 & $\begin{array}{l}\text { St Irenarchus the Martyr and St Stephen } \\
\text { the Younger the Hieromartyr. }\end{array}$ \\
\hline Nov. 29 & 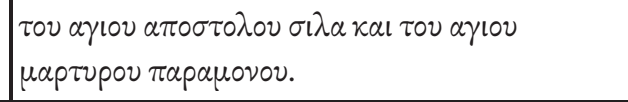 & $\begin{array}{l}\text { St Silas the Apostle and St Paramon the } \\
\text { Martyr. }\end{array}$ \\
\hline Nov. 30 & $\tau \circ \nu \alpha \gamma 10 \nu \alpha \pi \circ \sigma \tau 0 \lambda \circ \nu \alpha \nu \delta \rho \varepsilon \circ \nu$. & St Andrew the Apostle. \\
\hline Dec. 1 & 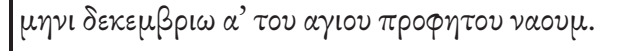 & December 1, The sainted Prophet Nahum. \\
\hline Dec. 2 & 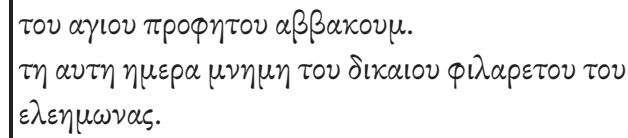 & $\begin{array}{l}\text { The sainted Prophet Habbakuk. } \\
\text { On the same day, commemoration of the } \\
\text { righteous Philaretos the Almsgiver. }\end{array}$ \\
\hline Dec. 3 & 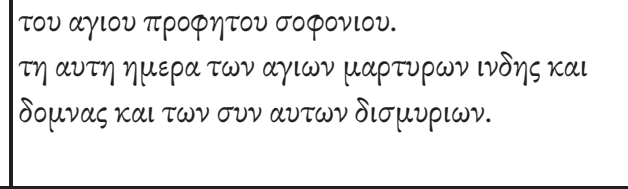 & $\begin{array}{l}\text { The sainted Prophet Zephaniah. } \\
\text { On the same day the martyrs St Indus, } \\
\text { Domna and the Twenty Thousand with } \\
\text { them. }\end{array}$ \\
\hline Dec. 4 & 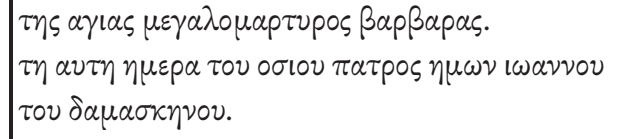 & $\begin{array}{l}\text { St Barbara the Great Martyr. } \\
\text { On the same day our holy father John } \\
\text { Damascene. }\end{array}$ \\
\hline Dec. 5 & 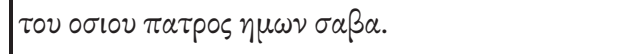 & Our holy father Sabbas. \\
\hline Dec. 6 & 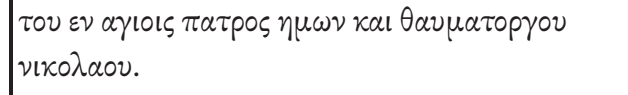 & $\begin{array}{l}\text { Our father Nicholas the wonderworker } \\
\text { among the saints. }\end{array}$ \\
\hline Dec. 7 & 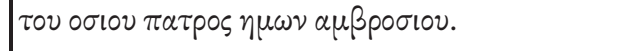 & Our holy father Ambrose. \\
\hline Dec. 8 & 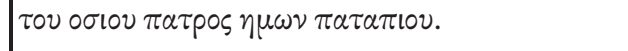 & Our holy father Patapius. \\
\hline Dec. 9 & $\eta \sigma \nu \lambda \lambda \eta \psi L s \tau \eta s \alpha \gamma / \alpha s \alpha \nu \nu \eta s$. & The Conception of St Anne. \\
\hline Dec. 10 & 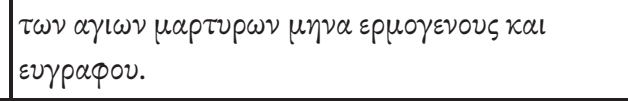 & $\begin{array}{l}\text { St Menas, Hermogenes and Eugraphus the } \\
\text { martyrs. }\end{array}$ \\
\hline Dec. 11 & 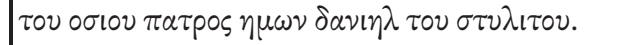 & Our holy father Daniel the Stylite. \\
\hline Dec. 12 & 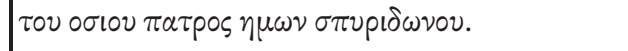 & Our holy father Spyridon. \\
\hline Dec. 13 & 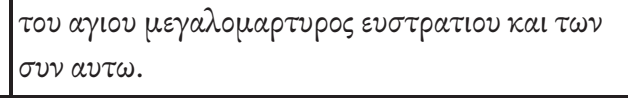 & $\begin{array}{l}\text { St Eustratius the Great Martyr and those } \\
\text { with him. }\end{array}$ \\
\hline Dec. 14 & 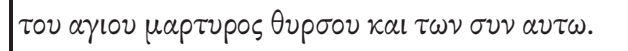 & St Thyrsus the Martyr and those with him. \\
\hline
\end{tabular}




\begin{tabular}{|c|c|c|}
\hline Day & Heading & Commemoration \\
\hline Dec. 15 & 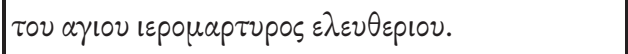 & St Eleutherius the Hieromartyr. \\
\hline Dec. 16 & 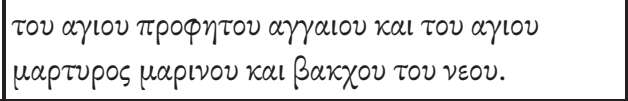 & $\begin{array}{l}\text { The sainted Prophet Haggai, St Marinus } \\
\text { the Martyr and Bacchus the Younger. }\end{array}$ \\
\hline Dec. 17 & 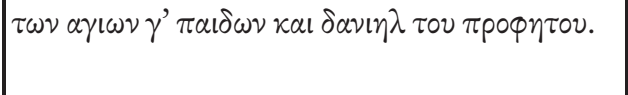 & $\begin{array}{l}\text { The three sainted children and Daniel the } \\
\text { prophet. }\end{array}$ \\
\hline Dec. 18 & 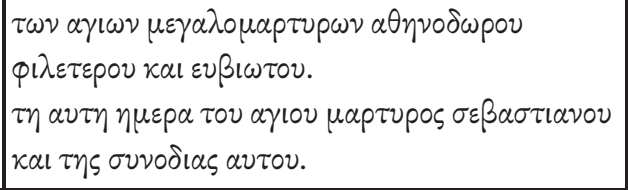 & $\begin{array}{l}\text { St Athenodorus, Phileteros and Eubiotus } \\
\text { the great-martyrs. } \\
\text { On the same day St Sebastian the Martyr } \\
\text { and his companions. }\end{array}$ \\
\hline Dec. 19 & 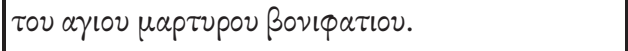 & St Boniface the Martyr. \\
\hline Dec. 20 & 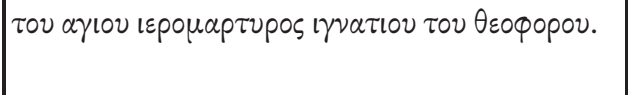 & $\begin{array}{l}\text { St Ignatius the God-bearer the } \\
\text { Hieromartyr. }\end{array}$ \\
\hline Dec. 21 & 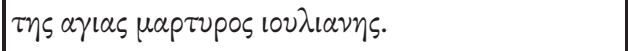 & St Juliana the Martyr. \\
\hline Dec. 22 & 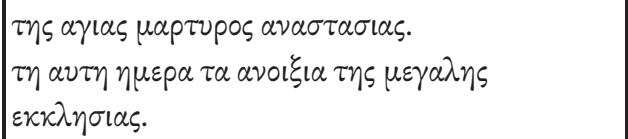 & $\begin{array}{l}\text { St Anastasia the Martyr. } \\
\text { On the same day the opening of the Great } \\
\text { Church. }{ }^{11}\end{array}$ \\
\hline \multirow[t]{3}{*}{ Dec. 23} & 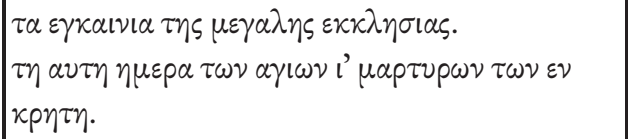 & $\begin{array}{l}\text { The Dedication of the Great Church. } \\
\text { On the same day the } 10 \text { martyrs of Crete. }\end{array}$ \\
\hline & 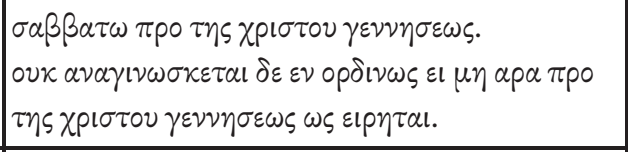 & $\begin{array}{l}\text { The Saturday before the birth of Christ. } \\
\text { This is not read sequentially except before } \\
\text { the birth of Christ as is stated. }{ }^{12}\end{array}$ \\
\hline & 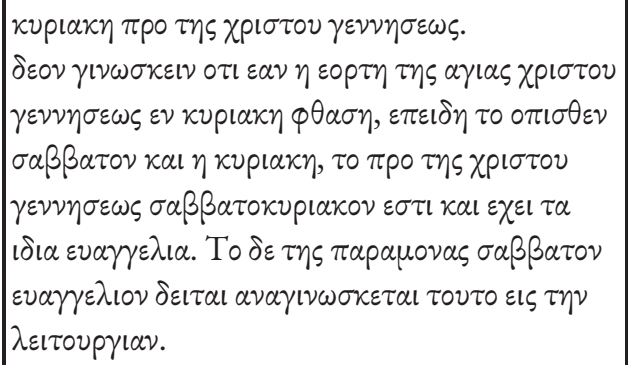 & $\begin{array}{l}\text { Sunday before the birth of Christ. } \\
\text { It must be known that if the feast of } \\
\text { Christ's holy birth falls on a Sunday, since } \\
\text { the preceding Saturday and Sunday (the } \\
\text { weekend before the birth of Christ) have } \\
\text { the same Gospels, then the Gospel of the } \\
\text { Vigil on Saturday should be read in the } \\
\text { Liturgy. }\end{array}$ \\
\hline Dec. 24 & 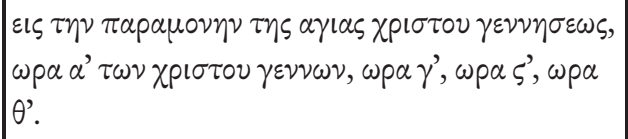 & $\begin{array}{l}\text { The Vigil of Christ's holy birth, hour } 1 \text { of } \\
\text { Christ's birth, hour 3, hour 6, hour } 9 . \\
\text { On the same day St Eugenia the Martyr. }\end{array}$ \\
\hline
\end{tabular}

\footnotetext{
${ }^{11}$ In Constantinople.

${ }^{12}$ See further the following entry.
} 


\begin{tabular}{|c|c|c|}
\hline Day & Heading & Commemoration \\
\hline & 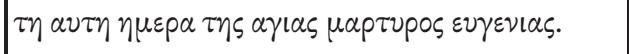 & \\
\hline Dec. 25 & 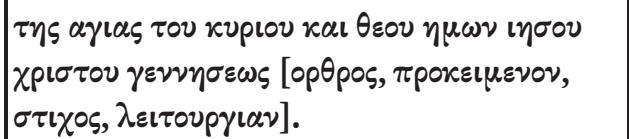 & $\begin{array}{l}\text { The Holy Birth of Jesus Christ our } \\
\text { Lord and God. }\end{array}$ \\
\hline \multirow[t]{3}{*}{ Dec. 26} & 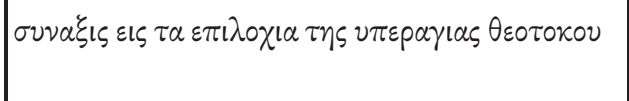 & $\begin{array}{l}\text { Service of the lying-in of the all-holy } \\
\text { Mother of God. }\end{array}$ \\
\hline & $\sigma \alpha \beta \beta \alpha \tau \omega \mu \varepsilon \tau \alpha \tau \eta \nu \chi p i \sigma \tau 0 \nu \gamma \varepsilon \nu \nu \eta \sigma \iota \nu$ & Saturday after the birth of Christ. \\
\hline & 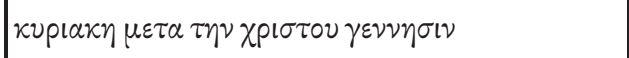 & Sunday after the birth of Christ. \\
\hline Dec. 27 & 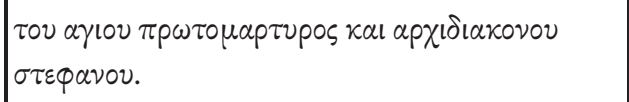 & St Stephen protomartyr and archdeacon. \\
\hline Dec. 28 & 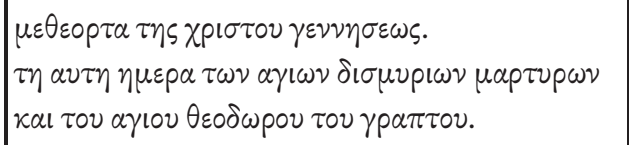 & $\begin{array}{l}\text { The afterfeast of the birth of Christ. } \\
\text { On the same day the Twenty Thousand } \\
\text { martyrs and St Theodore the writer. }\end{array}$ \\
\hline Dec. 29 & 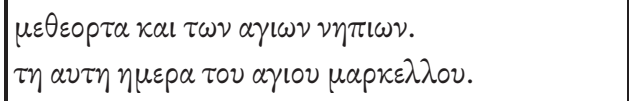 & $\begin{array}{l}\text { The afterfeast and the sainted children. } \\
\text { On the same day St Marcellus. }\end{array}$ \\
\hline Dec. 30 & $\begin{array}{l}\mu \varepsilon \theta \varepsilon \circ \rho \tau \alpha . \\
\tau \eta \alpha \nu \tau \eta \eta \mu \varepsilon \rho \alpha \eta \zeta s \alpha \jmath \alpha \varsigma \alpha \nu v \sigma \alpha \alpha s .\end{array}$ & $\begin{array}{l}\text { Afterfeast. } \\
\text { On the same day St Anysia. }\end{array}$ \\
\hline Dec. 31 & 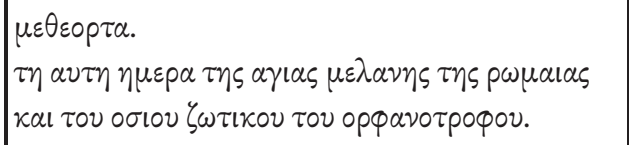 & $\begin{array}{l}\text { Afterfeast. } \\
\text { On the same day St Melania of Rome and } \\
\text { the holy Zoticus guardian of orphans. }\end{array}$ \\
\hline Jan. 1 & 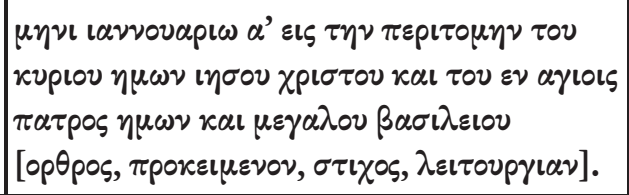 & $\begin{array}{l}\text { January } 1 . \text { The Circumcision of our } \\
\text { Lord Jesus Christ and our father among } \\
\text { the saints Basil the Great. }\end{array}$ \\
\hline Jan. 2 & 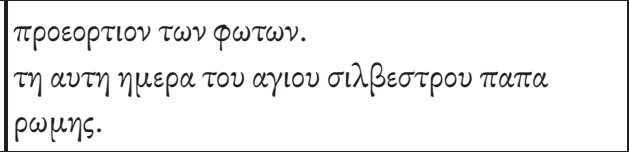 & $\begin{array}{l}\text { Forefeast of divine lights. } \\
\text { On the same day St Sylvester Pope of } \\
\text { Rome. }\end{array}$ \\
\hline Jan. 3 & 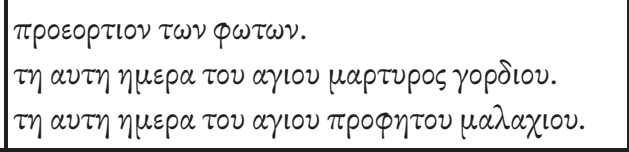 & $\begin{array}{l}\text { Forefeast of divine lights. } \\
\text { On the same day St Gordius the Martyr. } \\
\text { On the same day the holy Prophet Malachi. }\end{array}$ \\
\hline Jan. 4 & 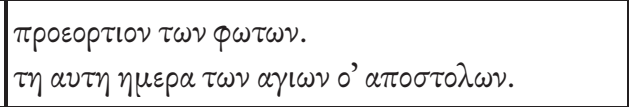 & $\begin{array}{l}\text { Forefeast of divine lights. } \\
\text { On the same day the sainted } 70 \text { Apostles. }\end{array}$ \\
\hline \multirow[t]{3}{*}{ Jan. 5} & 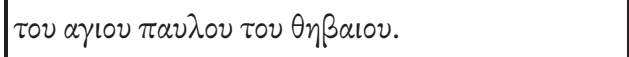 & St Paul of Thebes. \\
\hline & $\sigma \alpha \beta \beta \alpha \tau \omega \pi \rho \tau \sigma \tau \nu \nu \omega \tau \omega \nu$ & Saturday before divine lights. \\
\hline & 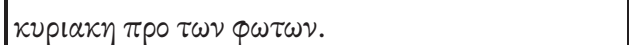 & Sunday before divine lights. \\
\hline
\end{tabular}




\begin{tabular}{|c|c|c|}
\hline Day & Heading & Commemoration \\
\hline $\begin{array}{l}\text { Jan. } 5 \\
\text { cont. }\end{array}$ & 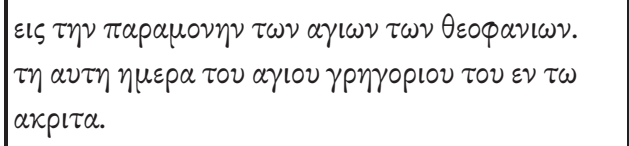 & $\begin{array}{l}\text { Vigil of the holy Theophany. } \\
\text { On the same day St Gregory of Akrita. }{ }^{13}\end{array}$ \\
\hline Jan. 6 & 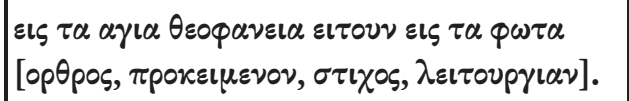 & $\begin{array}{l}\text { The holy Theophany or the divine } \\
\text { lights }\end{array}$ \\
\hline \multirow[t]{3}{*}{ Jan. 7} & 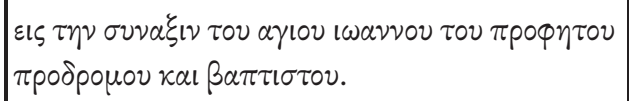 & $\begin{array}{l}\text { For the service of St John, the Prophet, } \\
\text { Forerunner and Baptist. }\end{array}$ \\
\hline & $\sigma \alpha \beta \beta \alpha \tau \omega \mu \varepsilon \tau \alpha \tau \alpha \varphi \omega \tau \alpha$. & Saturday after divine lights. \\
\hline & $\kappa v \rho ı \alpha \eta \mu \varepsilon \tau \alpha \tau \alpha \varphi \omega \tau \alpha$. & Sunday after divine lights. \\
\hline Jan. 8 & 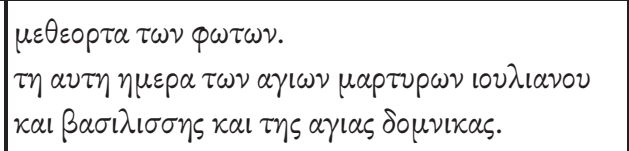 & $\begin{array}{l}\text { Afterfeast of divine lights. } \\
\text { On the same day St Julian and Basilissa the } \\
\text { martyrs, and St Domnica. }\end{array}$ \\
\hline Jan. 9 & 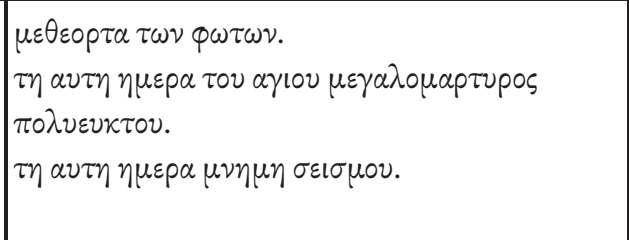 & $\begin{array}{l}\text { Afterfeast of divine lights. } \\
\text { On the same day St Polyeuctus the great- } \\
\text { martyr. } \\
\text { On the same day commemoration of the } \\
\text { Earthquake. }\end{array}$ \\
\hline Jan. 10 & 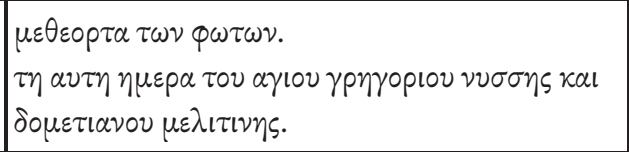 & $\begin{array}{l}\text { Afterfeast of divine lights. } \\
\text { On the same day St Gregory of Nyssa and } \\
\text { Dometian of Melitene. }\end{array}$ \\
\hline Jan. 11 & 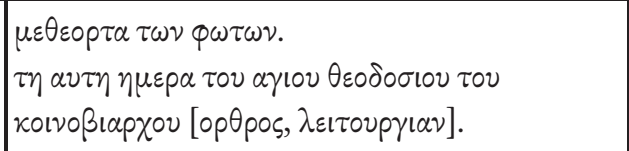 & $\begin{array}{l}\text { Afterfeast of divine lights. } \\
\text { On the same day St Theodosius the } \\
\text { Cenobiarch. }\end{array}$ \\
\hline Jan. 12 & 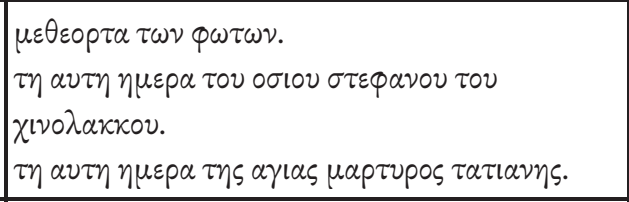 & $\begin{array}{l}\text { Afterfeast of divine lights. } \\
\text { On the same day the Holy Stephen of } \\
\text { Khenolakkos Monastery. } \\
\text { On the same day St Tatiana the Martyr. }\end{array}$ \\
\hline Jan. 13 & 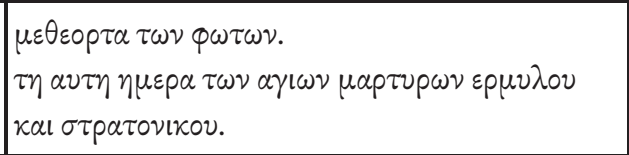 & $\begin{array}{l}\text { Afterfeast of divine lights. } \\
\text { On the same day St Hermylus and } \\
\text { Stratonicus the martyrs. }\end{array}$ \\
\hline Jan. 14 & $\tau \omega \nu \alpha \gamma i \omega \nu \alpha \beta \beta \alpha \delta \omega \nu$ & The sainted Abbots. ${ }^{14}$ \\
\hline
\end{tabular}

\footnotetext{
${ }^{13}$ Also known as Gregory of Crete.

${ }^{14}$ This refers to those slain at Sinai and Raithu.
} 


\begin{tabular}{|c|c|c|}
\hline Day & Heading & Commemoration \\
\hline Jan. 15 & 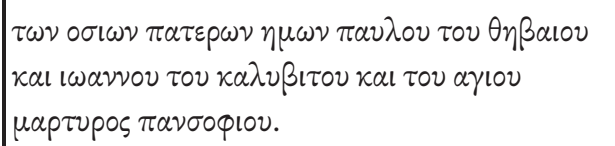 & $\begin{array}{l}\text { Our holy fathers Paul of Thebes and John } \\
\text { Calabytes and St Pansophius the Martyr. }\end{array}$ \\
\hline Jan. 16 & 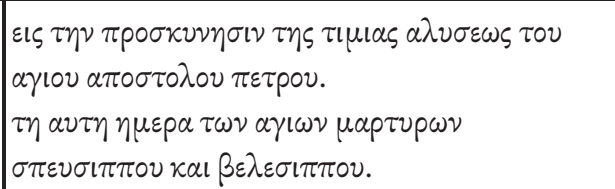 & $\begin{array}{l}\text { The adoration of the precious chain of St } \\
\text { Peter the Apostle. } \\
\text { On the same day St Speusippus and } \\
\text { Belesippus the martyrs. }\end{array}$ \\
\hline Jan. 17 & 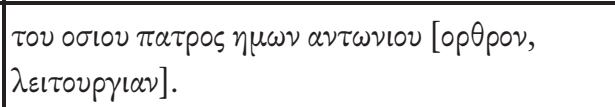 & Our holy father Anthony. \\
\hline Jan. 18 & 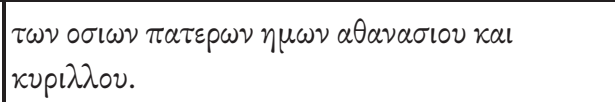 & Our holy fathers Athanasius and Cyril. \\
\hline Jan. 19 & 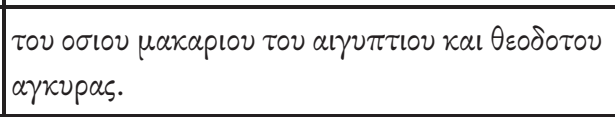 & $\begin{array}{l}\text { The holy Macarius of Egypt and } \\
\text { Theodotus of Ancyra. }\end{array}$ \\
\hline Jan. 20 & 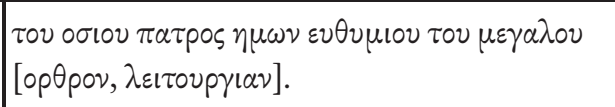 & Our holy father Euthymius the Great. \\
\hline Jan. 21 & 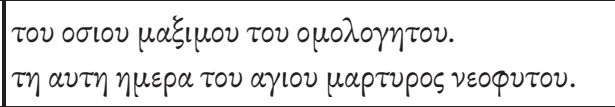 & $\begin{array}{l}\text { The holy Maximus the Confessor. } \\
\text { On the same day St Neophytus the Martyr. }\end{array}$ \\
\hline Jan. 22 & 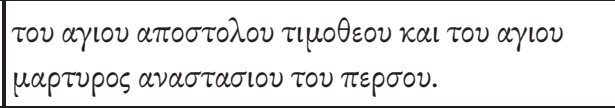 & $\begin{array}{l}\text { St Timothy the Apostle and St Anastasius } \\
\text { of Persia the Martyr. }\end{array}$ \\
\hline Jan. 23 & 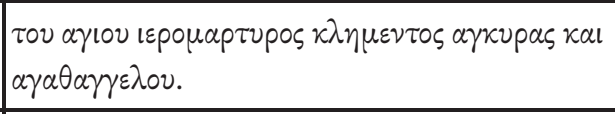 & $\begin{array}{l}\text { St Clement of Ancyra the Hieromartyr, and } \\
\text { Agathangelus. }\end{array}$ \\
\hline Jan. 24 & 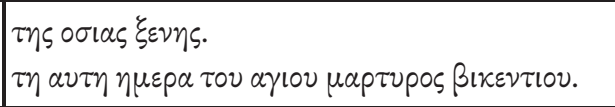 & $\begin{array}{l}\text { The holy Xenia. } \\
\text { On the same day St Vincent the Martyr. }\end{array}$ \\
\hline Jan. 25 & 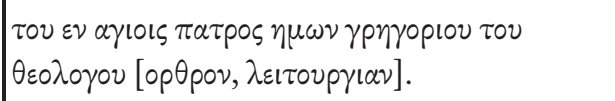 & $\begin{array}{l}\text { Our father among the saints Gregory the } \\
\text { Theologian. }\end{array}$ \\
\hline Jan. 26 & 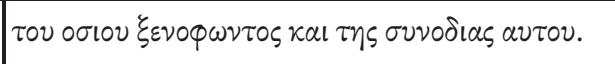 & The holy Xenophon and his companions. \\
\hline Jan. 27 & 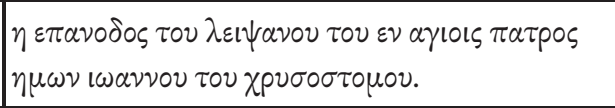 & $\begin{array}{l}\text { The translation of the relics of our father } \\
\text { among the saints John Chrysostom. }\end{array}$ \\
\hline Jan. 28 & 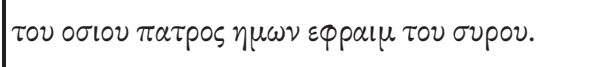 & Our holy father Ephraim the Syrian. \\
\hline Jan. 29 & 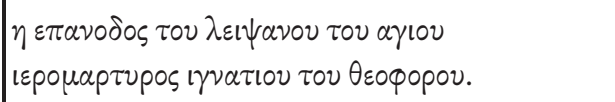 & $\begin{array}{l}\text { The translation of the relics of St Ignatius } \\
\text { the God-bearer, the Hieromartyr. }\end{array}$ \\
\hline Jan. 30 & 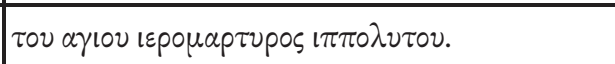 & St Hippolytus the Hieromartyr. \\
\hline
\end{tabular}




\begin{tabular}{|c|c|c|}
\hline Day & Heading & Commemoration \\
\hline Jan. 31 & 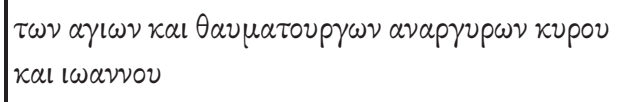 & $\begin{array}{l}\text { The holy wonderworkers and } \\
\text { unmercenaries Cyrus and John. }{ }^{15}\end{array}$ \\
\hline Feb. 1 & 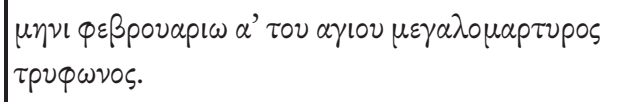 & February 1 . St Tryphon the great-martyr. \\
\hline Feb. 2 & 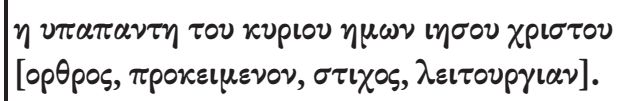 & $\begin{array}{l}\text { The Presentation of our Lord Jesus } \\
\text { Christ. }\end{array}$ \\
\hline Feb. 3 & 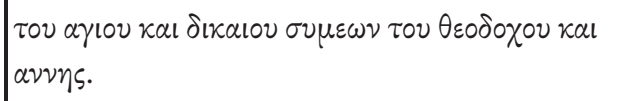 & $\begin{array}{l}\text { The sainted and just Symeon the God- } \\
\text { receiver and Anna. }\end{array}$ \\
\hline Feb. 4 & 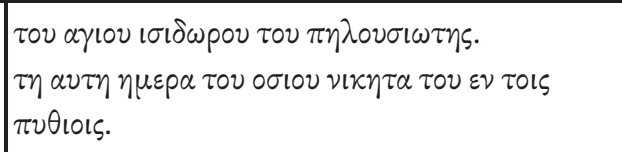 & $\begin{array}{l}\text { St Isidore of Pelusium. } \\
\text { On the same day the Holy Nicetas of } \\
\text { Pythiae. }\end{array}$ \\
\hline Feb. 5 & $\tau \eta s \alpha \gamma 1 \alpha s \alpha \gamma \alpha \theta \eta s$. & St Agatha. \\
\hline Feb. 6 & 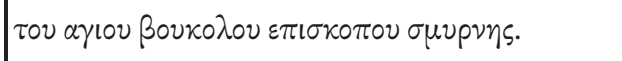 & St Bucolus, Bishop of Smyrna. \\
\hline Feb. 7 & 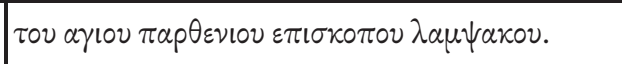 & St Parthenius, Bishop of Lampsacus. \\
\hline Feb. 8 & 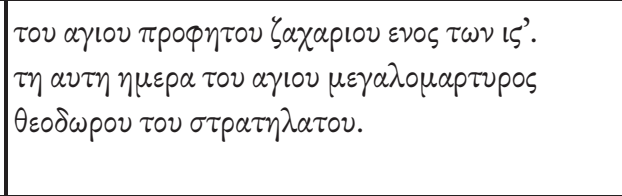 & $\begin{array}{l}\text { The sainted Prophet Zechariah, one of the } \\
16 . \\
\text { On the same day St Theodore Stratelates } \\
\text { the great-martyr. }\end{array}$ \\
\hline Feb. 9 & 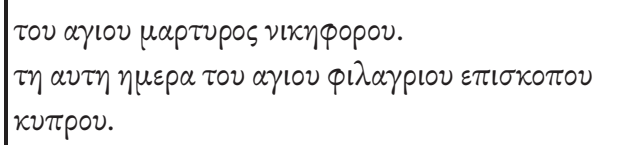 & $\begin{array}{l}\text { St Nicephorus the Martyr. } \\
\text { On the same day St Philagrius, Bishop of } \\
\text { Cyprus. }\end{array}$ \\
\hline Feb. 10 & 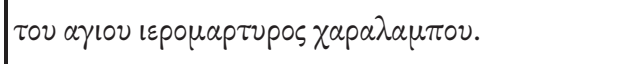 & St Charalampus the Hieromartyr. \\
\hline Feb. 11 & 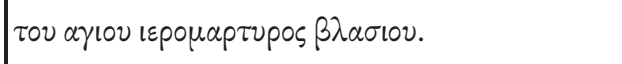 & St Blaise the Hieromartyr. \\
\hline Feb. 12 & 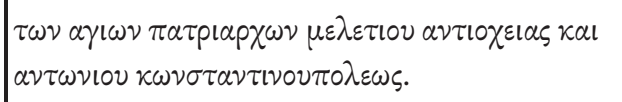 & $\begin{array}{l}\text { The Patriarchs St Meletius of Antioch and } \\
\text { Anthony of Constantinople. }\end{array}$ \\
\hline Feb. 13 & 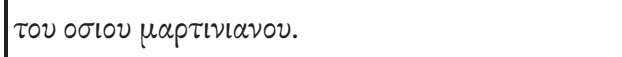 & The holy Martinian. \\
\hline Feb. 14 & 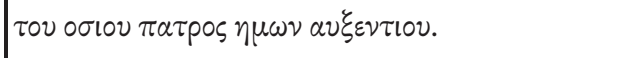 & Our holy father Auxentius. \\
\hline Feb. 15 & 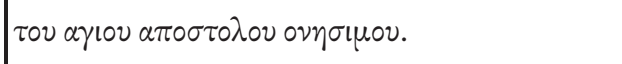 & St Onesimus the Apostle. \\
\hline Feb. 16 & 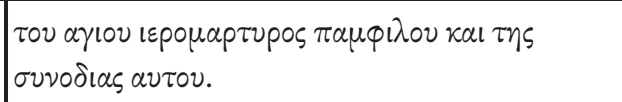 & $\begin{array}{l}\text { St Pamphilus the Hieromartyr and his } \\
\text { companions. }\end{array}$ \\
\hline
\end{tabular}

\footnotetext{
${ }^{15}$ For 'unmercenaries', see note on November 1.
} 


\begin{tabular}{|c|c|c|}
\hline Day & Heading & Commemoration \\
\hline Feb. 17 & 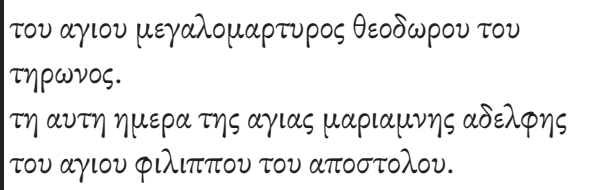 & $\begin{array}{l}\text { St Theodore Tyro, the Great-martyr. } \\
\text { On the same day St Mariamne, sister of St } \\
\text { Philip the Apostle. }\end{array}$ \\
\hline Feb. 18 & 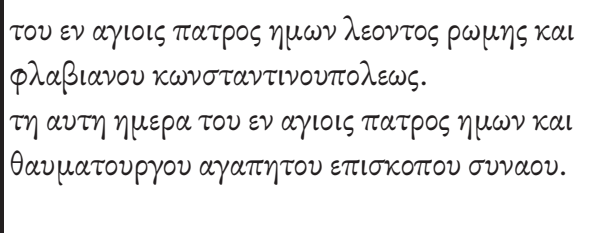 & $\begin{array}{l}\text { Our father among the saints Leo of Rome } \\
\text { and Flavian of Constantinople. } \\
\text { On the same day our father among the } \\
\text { saints Agapitus, Bishop of Synnada and } \\
\text { wonderworker. }\end{array}$ \\
\hline Feb. 19 & 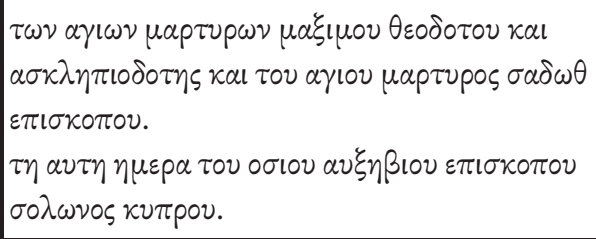 & $\begin{array}{l}\text { St Maximus, Theodotus and Asclepiodota } \\
\text { the martyrs, and the St Sadoth, bishop and } \\
\text { martyr. } \\
\text { On the same day the holy Auxebius, Bishop } \\
\text { of Solia in Cyprus. }\end{array}$ \\
\hline Feb. 20 & 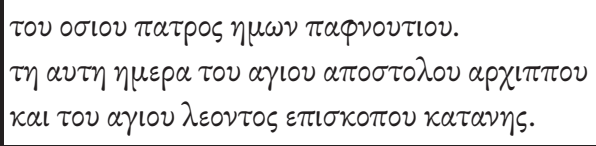 & $\begin{array}{l}\text { Our holy father Paphnutius. } \\
\text { On the same day St Archippus the Apostle } \\
\text { and St Leo Bishop of Catania. }\end{array}$ \\
\hline Feb. 21 & 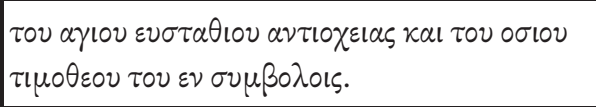 & $\begin{array}{l}\text { St Eustathius of Antioch and the holy } \\
\text { Timothy of Symbola. }\end{array}$ \\
\hline Feb. 22 & 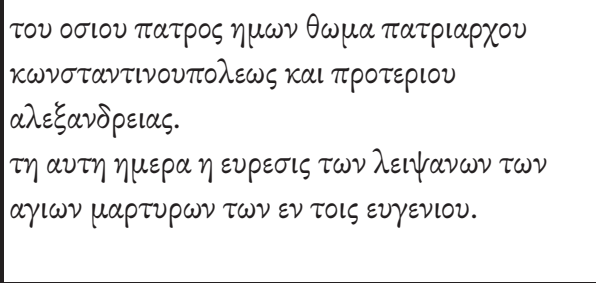 & $\begin{array}{l}\text { Our holy father Thomas Patriarch of } \\
\text { Constantinople and Proterius of } \\
\text { Alexandria. } \\
\text { On the same day the discovery of the relics } \\
\text { of the sainted martyrs at the Gate of } \\
\text { Eugenius. }\end{array}$ \\
\hline Feb. 23 & 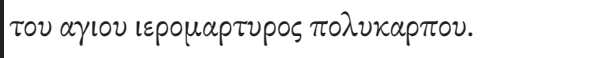 & St Polycarp the Hieromartyr. \\
\hline Feb. 24 & 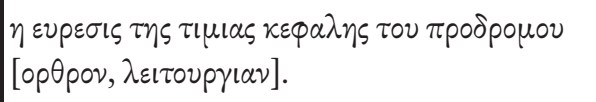 & $\begin{array}{l}\text { The discovery of the precious head of the } \\
\text { Forerunner. }\end{array}$ \\
\hline Feb. 25 & 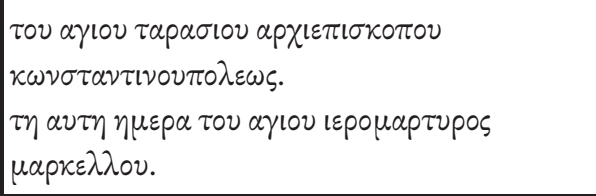 & $\begin{array}{l}\text { St Tarasius Archbishop of Constantinople. } \\
\text { On the same day St Marcellus the } \\
\text { Hieromartyr. }\end{array}$ \\
\hline Feb. 26 & 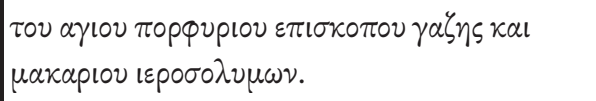 & $\begin{array}{l}\text { St Porphyry Bishop of Gaza and Macarius } \\
\text { of Jerusalem. }\end{array}$ \\
\hline Feb. 27 & 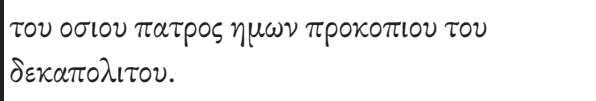 & Our holy father Procopius of Decapolis. \\
\hline Feb. 28 & 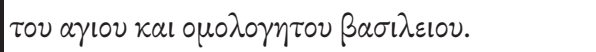 & St Basil the Confessor. \\
\hline
\end{tabular}




\begin{tabular}{|c|c|c|}
\hline Day & Heading & Commemoration \\
\hline Feb. 29 & $\begin{array}{l}\tau \omega \nu \alpha \gamma เ \omega \nu \mu \alpha \rho \tau \nu \rho \omega \nu \pi \alpha \pi เ \alpha \delta 10 \delta \omega \rho \circ v \text { kal } \\
\kappa \lambda \alpha \nu \delta 10 v .\end{array}$ & $\begin{array}{l}\text { St Papias, Diadorus and Claudius the } \\
\text { martyrs. }\end{array}$ \\
\hline Mar. 1 & 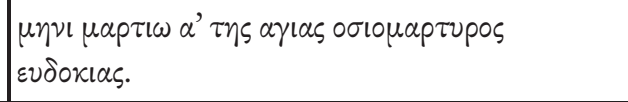 & March 1, St Eudokia the holy martyr. \\
\hline Mar. 2 & 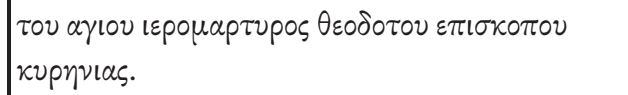 & $\begin{array}{l}\text { St Theodotus the Hieromartyr and Bishop } \\
\text { of Cyrenia. }\end{array}$ \\
\hline Mar. 3 & 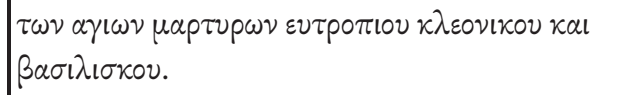 & $\begin{array}{l}\text { St Eutropius, Cleonicus and Basiliscus the } \\
\text { martyrs. }\end{array}$ \\
\hline Mar. 4 & 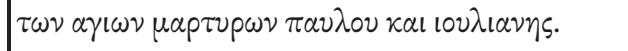 & St Paul and Juliana the martyrs. \\
\hline Mar. 5 & 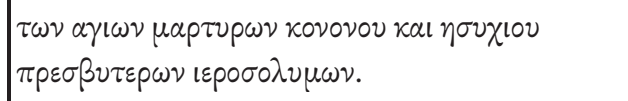 & $\begin{array}{l}\text { St Conon and Hesychius the martyrs, elders } \\
\text { of Jerusalem. }\end{array}$ \\
\hline Mar. 6 & $\tau \omega \nu \alpha \gamma i \omega(\nu) \mu \beta^{\prime} \mu \alpha \rho \tau \nu \rho \omega \nu \tau \omega \nu \varepsilon \nu \tau \omega \alpha \mu \omega \rho i \omega$. & The sainted 42 martyrs of Amorium. \\
\hline Mar. 7 & 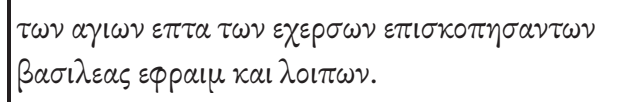 & $\begin{array}{l}\text { The sainted seven acting as Bishops in } \\
\text { Cherson, Basil, Ephraim and the others. }\end{array}$ \\
\hline Mar. 8 & 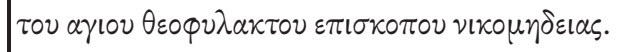 & St Theophylact, Bishop of Nicomedia. \\
\hline Mar. 9 & $\tau \omega \nu \alpha \gamma\left(\omega \nu \mu^{\prime} \mu \alpha \rho \tau \nu \rho \omega \nu \tau \omega \nu \varepsilon \nu \sigma \varepsilon \beta \alpha \sigma \tau 1 \alpha\right.$. & The sainted 40 martyrs in Sebaste. \\
\hline Mar. 10 & 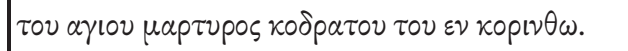 & St Quadratus of Corinth, martyr. \\
\hline Mar. 11 & 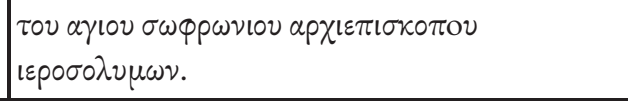 & St Sophronius, Archbishop of Jerusalem. \\
\hline Mar. 12 & 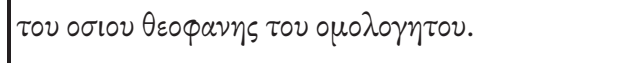 & The holy Theophanes the Confessor. \\
\hline Mar. 13 & 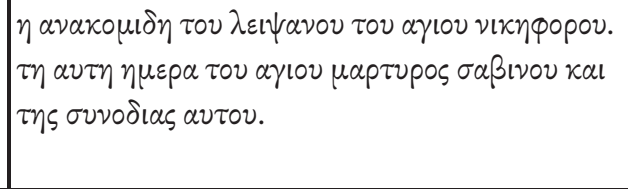 & $\begin{array}{l}\text { The translation of the relics of St } \\
\text { Nicephorus. } \\
\text { On the same day St Sabinus the Martyr and } \\
\text { companions. }\end{array}$ \\
\hline Mar. 14 & 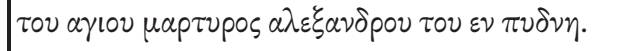 & St Alexander of Pydnus, martyr. \\
\hline Mar. 15 & 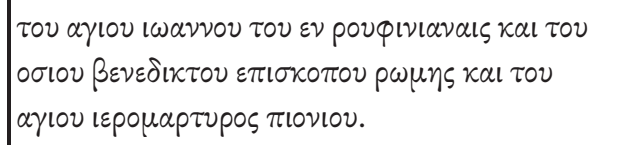 & $\begin{array}{l}\text { St John of Rouphinianai, }{ }^{16} \text { Benedict Bishop } \\
\text { of Rome, St Pionius the Hieromartyr. }\end{array}$ \\
\hline Mar. 16 & 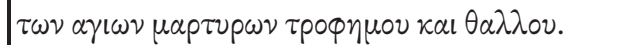 & St Trophimus and Thallus the martyrs. \\
\hline
\end{tabular}

${ }^{16}$ This monastery in Constantinople is also known as Rufinianes. 


\begin{tabular}{|c|c|c|}
\hline Day & Heading & Commemoration \\
\hline Mar. 17 & 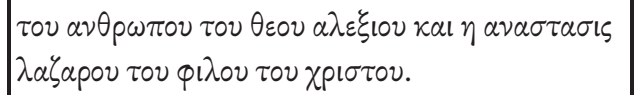 & $\begin{array}{l}\text { Alexios the man of God, and the } \\
\text { resurrection of Lazarus the friend of Christ. }\end{array}$ \\
\hline Mar. 18 & 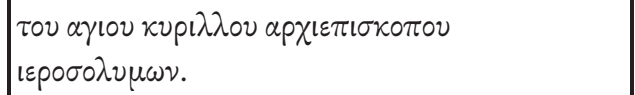 & St Cyril Archbishop of Jerusalem. \\
\hline Mar. 19 & $\tau \omega \nu \alpha \gamma(\omega \nu \mu \alpha \rho \tau \nu \rho \omega \nu \chi \rho \nu \sigma \alpha \nu \theta 0 \nu$ kal $\delta \alpha \rho ı \varsigma$. & St Chrysanthus and Daria the martyrs. \\
\hline Mar. 20 & 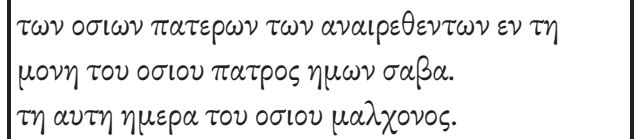 & $\begin{array}{l}\text { The holy fathers killed in the monastery of } \\
\text { our holy father Sabbas. } \\
\text { On the same day the holy Malchus. }\end{array}$ \\
\hline Mar. 21 & 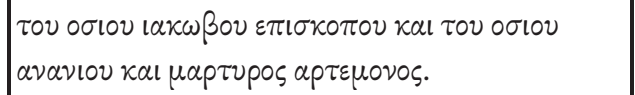 & $\begin{array}{l}\text { The holy James the bishop, the holy } \\
\text { Ananias and the martyr Artemon. }\end{array}$ \\
\hline Mar. 22 & 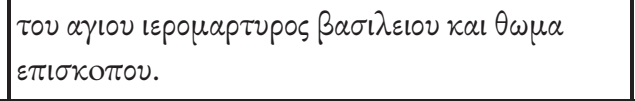 & $\begin{array}{l}\text { St Basil the Hieromartyr and Thomas the } \\
\text { Bishop. }\end{array}$ \\
\hline Mar. 23 & 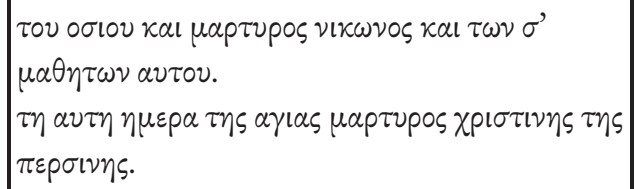 & $\begin{array}{l}\text { The holy Nikon the Martyr and his } 200 \\
\text { disciples. } \\
\text { On the same day St Christina of Persia, } \\
\text { martyr. }\end{array}$ \\
\hline Mar. 24 & 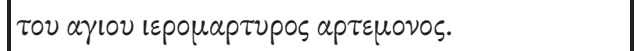 & St Artemon the Hieromartyr. \\
\hline Mar. 25 & 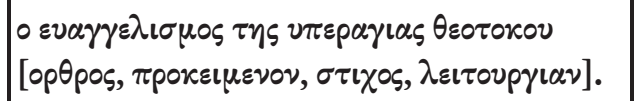 & $\begin{array}{l}\text { The Annunciation of the all-holy } \\
\text { Mother of God. }\end{array}$ \\
\hline Mar. 26 & 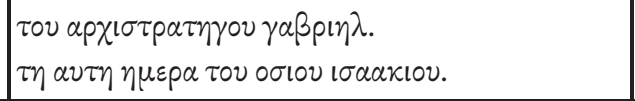 & $\begin{array}{l}\text { The Archangel Gabriel. } \\
\text { On the same day the Holy Isaac. }\end{array}$ \\
\hline Mar. 27 & 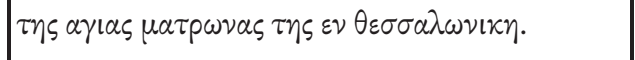 & St Matrona of Thessaloniki. \\
\hline Mar. 28 & 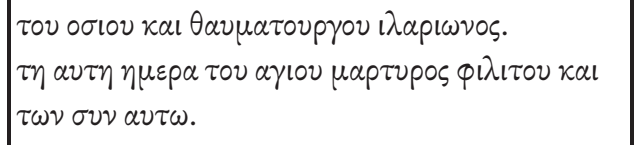 & $\begin{array}{l}\text { The holy Hilarion the wonderworker. } \\
\text { On the same day St Philetus the Martyr and } \\
\text { those with him. }\end{array}$ \\
\hline Mar. 29 & 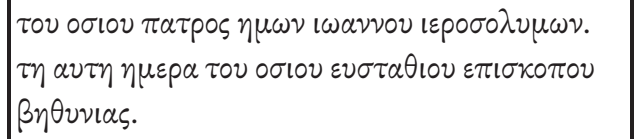 & $\begin{array}{l}\text { Our holy father John of Jerusalem. } \\
\text { On the same day the holy Eustathius } \\
\text { Bishop of Bithynia. }\end{array}$ \\
\hline Mar. 30 & 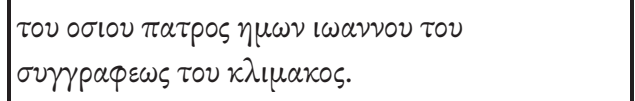 & $\begin{array}{l}\text { Our holy father John who wrote the } \\
\text { Ladder. }{ }^{17}\end{array}$ \\
\hline Mar. 31 & $\tau \omega \nu \alpha \gamma l \omega \nu \mu \alpha \rho \tau \tau \rho \omega \nu \mu \varepsilon \nu \alpha \nu \delta \rho \circ \nu$ kal $\nu \varepsilon \circ \varphi v \tau O \nu$. & St Menander and Neophytus, martyrs. \\
\hline Apr. 1 & 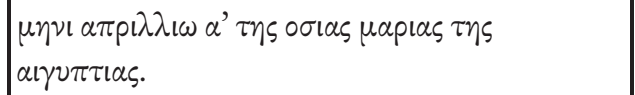 & April 1, The holy Mary of Egypt. \\
\hline
\end{tabular}

\footnotetext{
${ }^{17}$ i.e. John Climacus.
} 


\begin{tabular}{|c|c|c|}
\hline Day & Heading & Commemoration \\
\hline Apr. 2 & 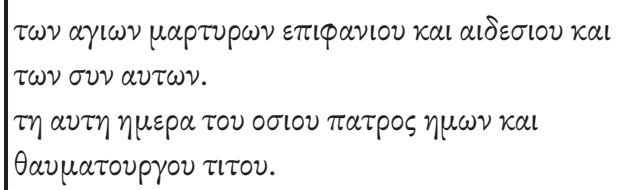 & $\begin{array}{l}\text { St Epiphanius and Aedesius, martyrs, and } \\
\text { those with them. } \\
\text { On the same day our holy father Titus the } \\
\text { wonderworker. }\end{array}$ \\
\hline Apr. 3 & 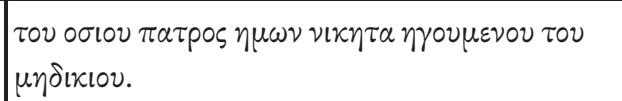 & Our holy father Nicetas abbot of Medikion. \\
\hline Apr. 4 & 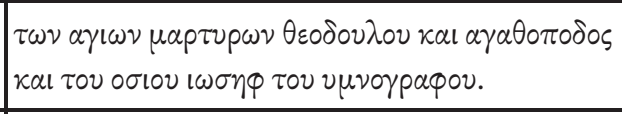 & $\begin{array}{l}\text { St Theodulus and Agathapodes the martyrs } \\
\text { and the holy Joseph the Hymnographer. }\end{array}$ \\
\hline Apr. 5 & 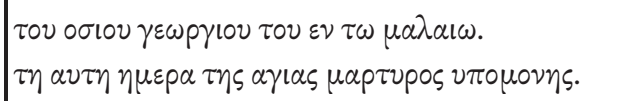 & $\begin{array}{l}\text { The holy George of Malaion. } \\
\text { On the same day St Hypomene the Martyr. }\end{array}$ \\
\hline Apr. 6 & 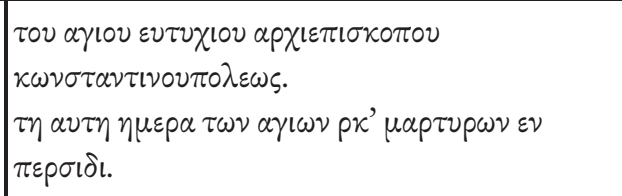 & $\begin{array}{l}\text { St Eutychius Archbishop of } \\
\text { Constantinople. } \\
\text { On the same day the sainted } 120 \text { martyrs in } \\
\text { Persia. }\end{array}$ \\
\hline Apr. 7 & 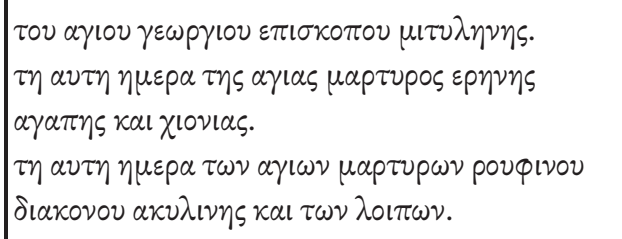 & $\begin{array}{l}\text { St George Bishop of Mytilene. } \\
\text { On the same day St Irene, Agape and } \\
\text { Chionia, martyr. } \\
\text { On the same day St Rufinus the deacon, } \\
\text { Aquilina and the others, martyrs. }\end{array}$ \\
\hline Apr. 8 & 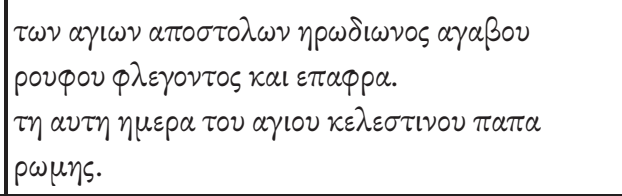 & $\begin{array}{l}\text { St Herodion, Agabus, Rufus, Phlegon and } \\
\text { Epaphre, Apostles. } \\
\text { On the same day St Celestine Pope of } \\
\text { Rome. }\end{array}$ \\
\hline Apr. 9 & 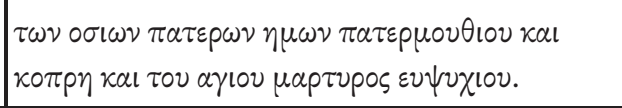 & $\begin{array}{l}\text { Our holy fathers Patermouthios and } \\
\text { Kopres, and St Eupsychius the Martyr. }\end{array}$ \\
\hline Apr. 10 & 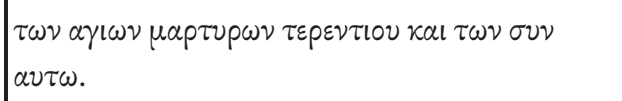 & St Terence and those with him, martyrs. \\
\hline Apr. 11 & 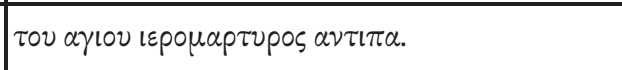 & St Antipas the Hieromartyr. \\
\hline Apr. 12 & 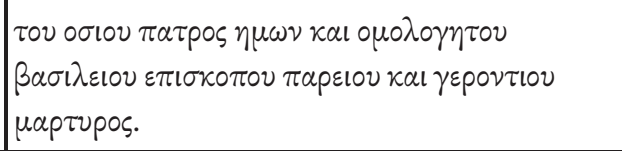 & $\begin{array}{l}\text { Our holy father Basil the Confessor, Bishop } \\
\text { of Parium and Gerontius the Martyr. }\end{array}$ \\
\hline Apr. 13 & 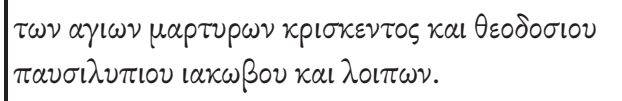 & $\begin{array}{l}\text { St Kriskes, Theodosius, Pausilypos, James } \\
\text { and the others, martyrs. }\end{array}$ \\
\hline Apr. 14 & 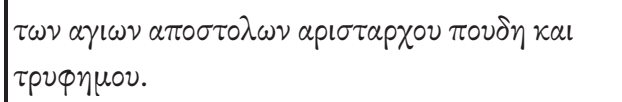 & $\begin{array}{l}\text { St Aristarchus, Pudens and Trophimus, } \\
\text { apostles. }\end{array}$ \\
\hline
\end{tabular}




\begin{tabular}{|c|c|c|}
\hline Day & Heading & Commemoration \\
\hline Apr. 15 & 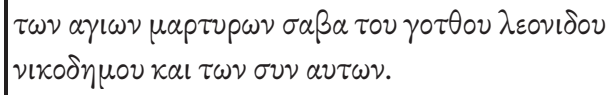 & $\begin{array}{l}\text { St Sabbas the Goth, Leonidas, Nicodemus } \\
\text { and those with them, martyrs. }\end{array}$ \\
\hline Apr. 16 & 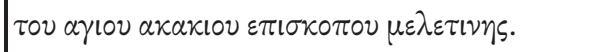 & St Acacius Bishop of Melitene. \\
\hline Apr. 17 & 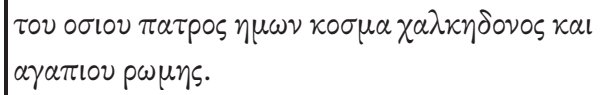 & $\begin{array}{l}\text { Our holy father Cosmas of Chalcedon and } \\
\text { Agapius of Rome. }\end{array}$ \\
\hline Apr. 18 & 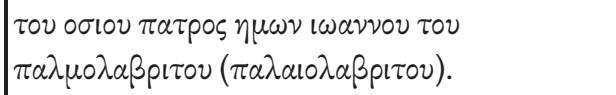 & Our holy father John of Old Lavra. \\
\hline Apr. 19 & 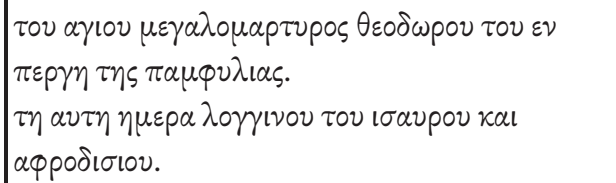 & $\begin{array}{l}\text { St Theodore of Perge in Pamphylia, the } \\
\text { great-martyr. } \\
\text { On the same day Longinus the Isaurian and } \\
\text { Aphrodisius. }\end{array}$ \\
\hline Apr. 20 & 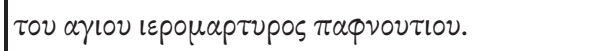 & St Paphnutius the Hieromartyr. \\
\hline Apr. 21 & 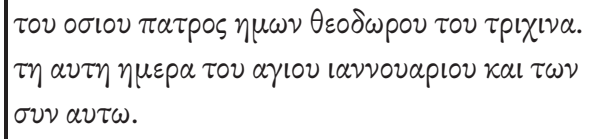 & $\begin{array}{l}\text { Our holy father Theodore Trichinas. } \\
\text { On the same day St Januarius and those } \\
\text { with him. }\end{array}$ \\
\hline Apr. 22 & 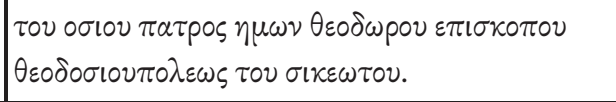 & $\begin{array}{l}\text { Our holy father Theodore the Sykeote, } \\
\text { Bishop of Theodosioupolis. }\end{array}$ \\
\hline Apr. 23 & 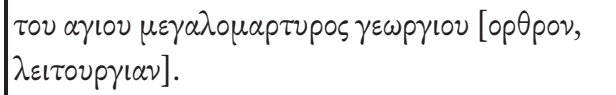 & St George the Great Martyr. \\
\hline Apr. 24 & 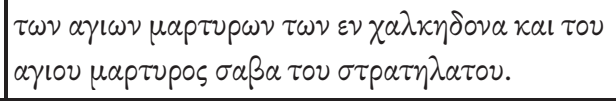 & $\begin{array}{l}\text { The sainted Martyrs in Chalcedon, St } \\
\text { Sabbas Stratelates the Martyr. }\end{array}$ \\
\hline Apr. 25 & 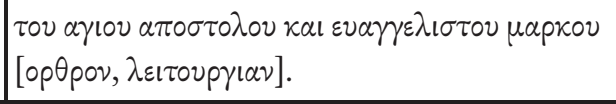 & St Mark the Apostle and Evangelist. \\
\hline Apr. 26 & 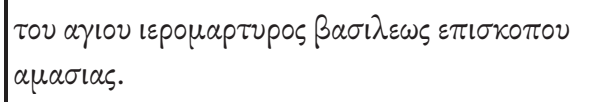 & St Basil Bishop of Amasea, Hieromartyr. \\
\hline Apr. 27 & 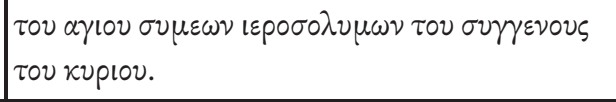 & $\begin{array}{l}\text { St Symeon of Jerusalem, kinsman of the } \\
\text { Lord. }\end{array}$ \\
\hline Apr. 28 & 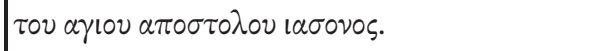 & St Jason the Apostle. \\
\hline Apr. 29 & 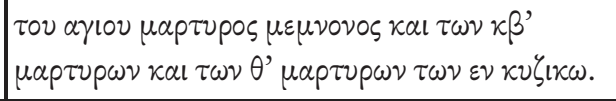 & $\begin{array}{l}\text { St Memnon the Martyr and } 22 \text { martyrs, and } \\
9 \text { martyrs in Kyzikos. }\end{array}$ \\
\hline Apr. 30 & 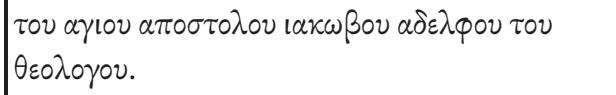 & $\begin{array}{l}\text { St James the Apostle, brother of the } \\
\text { Theologian. }\end{array}$ \\
\hline May 1 & 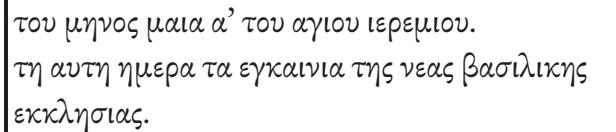 & $\begin{array}{l}\text { May } 1, \text { St Jeremiah. } \\
\text { On the same day the dedication of the new } \\
\text { imperial Church. }\end{array}$ \\
\hline
\end{tabular}




\begin{tabular}{|c|c|c|}
\hline Day & Heading & Commemoration \\
\hline May 2 & 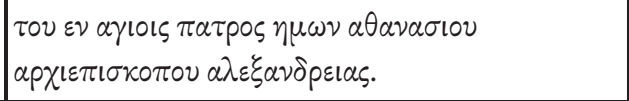 & $\begin{array}{l}\text { Our father among the saints Athanasius, } \\
\text { Archbishop of Alexandria. }\end{array}$ \\
\hline May 3 & 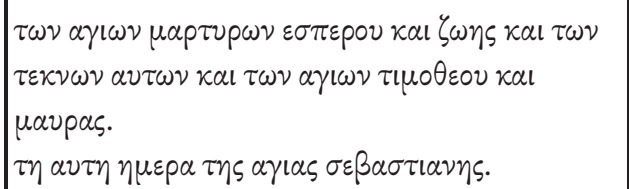 & $\begin{array}{l}\text { St Hesperos and Zoe and their children, } \\
\text { martyrs, and St Timothy and Maura. } \\
\text { On the same day St Sebastiana. }\end{array}$ \\
\hline May 4 & 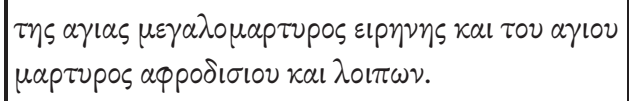 & $\begin{array}{l}\text { St Irene the Great Martyr and St } \\
\text { Aphrodisius the Martyr and the others. }\end{array}$ \\
\hline May 5 & 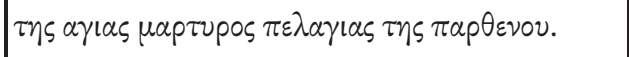 & St Pelagia the Virgin, martyr. \\
\hline May 6 & 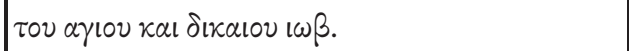 & The sainted and righteous. \\
\hline May 7 & 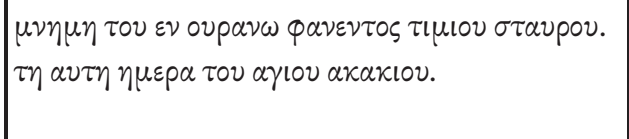 & $\begin{array}{l}\text { Commemoration of the appearance in } \\
\text { heaven of the Precious Cross. } \\
\text { On the same day St Acacius. }\end{array}$ \\
\hline May 8 & 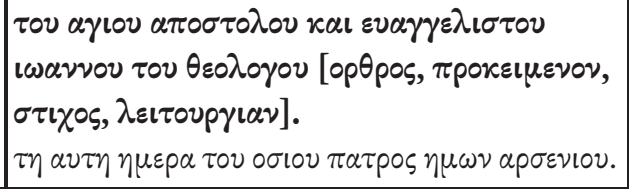 & $\begin{array}{l}\text { St John the Theologian, apostle and } \\
\text { evangelist. } \\
\text { On the same day our holy father Arsenius. }\end{array}$ \\
\hline May 9 & 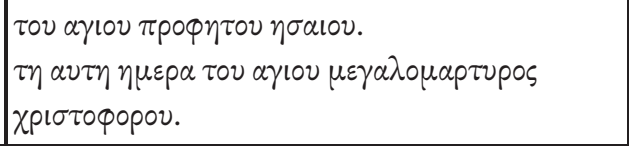 & $\begin{array}{l}\text { The sainted Prophet Isaiah. } \\
\text { On the same day St Christopher, Great } \\
\text { Martyr. }\end{array}$ \\
\hline May 10 & 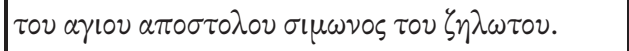 & St Simon the Zealot, Apostle. \\
\hline May 11 & 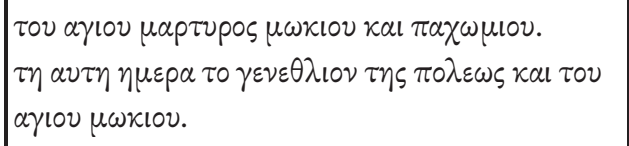 & $\begin{array}{l}\text { St Mocius the Martyr and Pachomius. } \\
\text { On the same day the founding of the City } \\
\text { and St Mocius. }\end{array}$ \\
\hline May 12 & 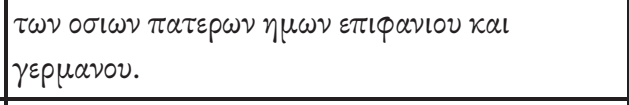 & $\begin{array}{l}\text { Our holy fathers Epiphanius and } \\
\text { Germanus. }\end{array}$ \\
\hline May 13 & $\begin{array}{l}\tau \circ v \alpha \gamma 10 v \alpha \lambda \varepsilon \xi \alpha \nu \delta \rho \circ v . \\
\tau \eta \alpha \nu \tau \eta \eta \mu \varepsilon \rho \alpha \tau \eta s \alpha \gamma l \alpha \varsigma \gamma \lambda v \kappa \varepsilon p l \alpha s .\end{array}$ & $\begin{array}{l}\text { St Alexander. } \\
\text { On the same day St Glyceria. }\end{array}$ \\
\hline May 14 & $\tau 0 v \alpha \gamma 10 v \mu \alpha \rho \tau \tau \rho \circ \varsigma$ เ $\sigma \delta \delta \omega \rho \circ v$. & St Isidore the Martyr. \\
\hline May 15 & 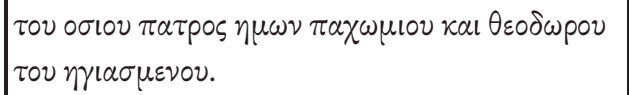 & $\begin{array}{l}\text { Our holy father Pachomius and Theodore } \\
\text { the sanctified. }\end{array}$ \\
\hline
\end{tabular}

\footnotetext{
${ }^{18}$ i.e. Constantinople.
} 


\begin{tabular}{|c|c|c|}
\hline Day & Heading & Commemoration \\
\hline May 16 & 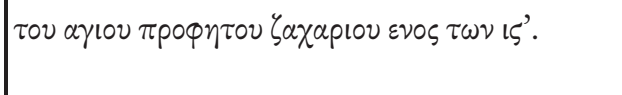 & $\begin{array}{l}\text { The sainted Prophet Zachariah, one of the } \\
16 .\end{array}$ \\
\hline May 17 & 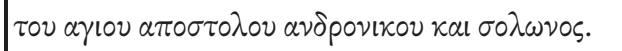 & St Andronicus the Apostle and Solon. \\
\hline May 18 & 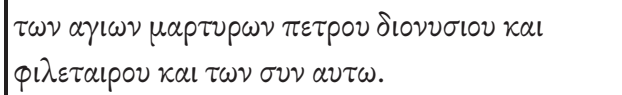 & $\begin{array}{l}\text { St Peter, Dionysius, Philetairus and those } \\
\text { with him, martyrs. }\end{array}$ \\
\hline May 19 & 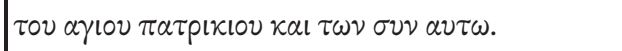 & St Patrick and those with him. \\
\hline May 20 & $\tau 0 \nu \alpha \gamma 10 v \mu \alpha \rho \tau \nu \rho \circ \beta \theta \alpha \lambda \varepsilon \lambda \alpha 10 v$. & St Thalelaeus the Martyr. \\
\hline May 21 & 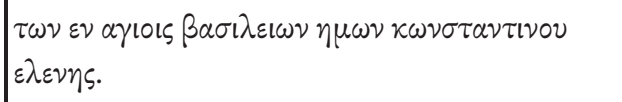 & $\begin{array}{l}\text { Our emperors Constantine and Helena } \\
\text { among the saints. }\end{array}$ \\
\hline May 22 & 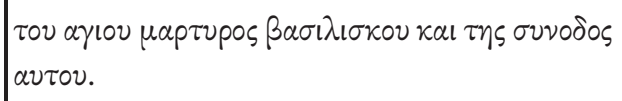 & $\begin{array}{l}\text { St Basiliscus the Martyr and his } \\
\text { companions. }\end{array}$ \\
\hline May 23 & 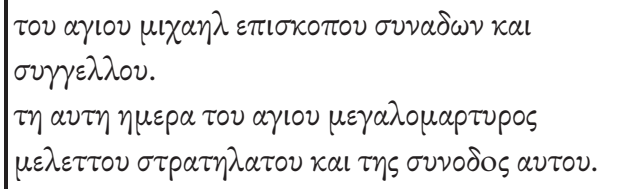 & $\begin{array}{l}\text { St Michael Bishop of Synnada and } \\
\text { Synkellos. } \\
\text { On the same day St Meletius Stratelates the } \\
\text { Great Martyr and companions. }\end{array}$ \\
\hline May 24 & 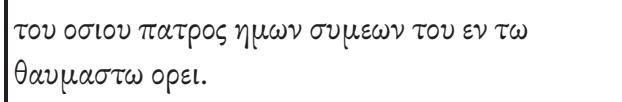 & $\begin{array}{l}\text { Our holy father Symeon of the wonderful } \\
\text { mountain. }\end{array}$ \\
\hline May 25 & 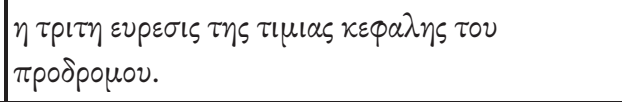 & $\begin{array}{l}\text { The third discovery of the precious head of } \\
\text { the Forerunner. }\end{array}$ \\
\hline May 26 & 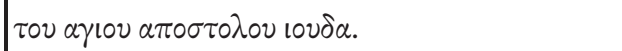 & St Jude the Apostle. \\
\hline May 27 & 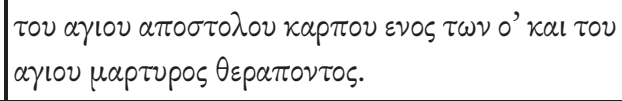 & $\begin{array}{l}\text { St Carpius the Apostle, one of the } 70 \text { and St } \\
\text { Therapon the Martyr. }\end{array}$ \\
\hline May 28 & 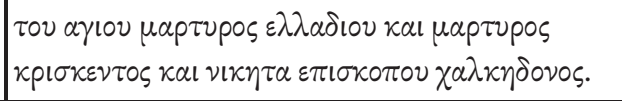 & $\begin{array}{l}\text { St Helladius and Kriskes, martyrs, and } \\
\text { Nicetas Bishop of Chalcedon. }\end{array}$ \\
\hline May 29 & 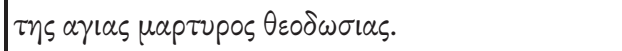 & St Theodosia the Martyr. \\
\hline May 30 & 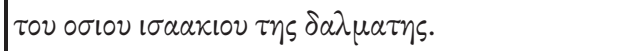 & The holy Isaac the Dalmatian. \\
\hline May 31 & 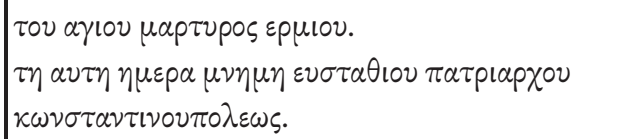 & $\begin{array}{l}\text { St Hermes the Martyr. } \\
\text { On the same day commemoration of } \\
\text { Eustathius Patriarch of Constantinople. }\end{array}$ \\
\hline June 1 & 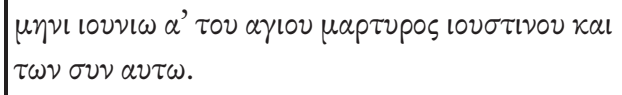 & $\begin{array}{l}\text { June } 1 \text {. St Justin the Martyr and those with } \\
\text { him. }\end{array}$ \\
\hline June 2 & 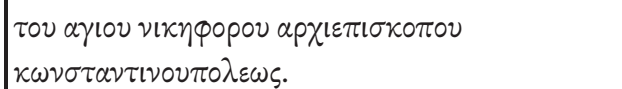 & $\begin{array}{l}\text { St Nicephorus Archbishop of } \\
\text { Constantinople. }\end{array}$ \\
\hline
\end{tabular}




\begin{tabular}{|c|c|c|}
\hline Day & Heading & Commemoration \\
\hline June 3 & $\begin{array}{l}\tau 0 \nu \alpha \gamma 10 v \mu \alpha \rho \tau \nu \rho \circ \zeta \lambda o v \kappa \iota \alpha \nu \circ v \text { kal } \tau \omega \nu \sigma \nu \nu \\
\alpha \nu \tau \omega .\end{array}$ & St Lucian the Martyr and those with him. \\
\hline June 4 & 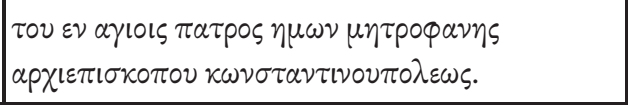 & $\begin{array}{l}\text { Our father among the saints Metrophanes } \\
\text { Archbishop of Constantinople. }\end{array}$ \\
\hline June 5 & 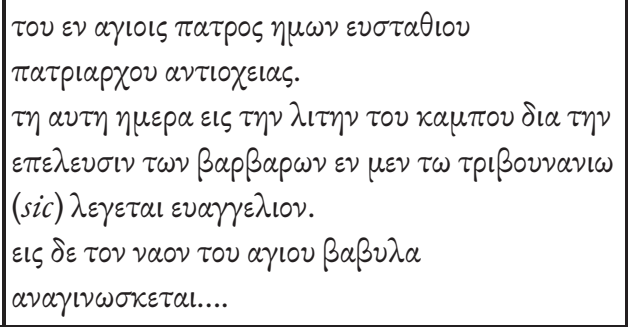 & $\begin{array}{l}\text { Our father among the saints Eustathius } \\
\text { Archbishop of Antioch. } \\
\text { On the same day in the Litany of the } \\
\text { Kampos, on account of the attack of the } \\
\text { Barbarians, in the Tribunal is read the } \\
\text { Gospel. }{ }^{19} \\
\text { In the church of St Babylas is read... }\end{array}$ \\
\hline June 6 & 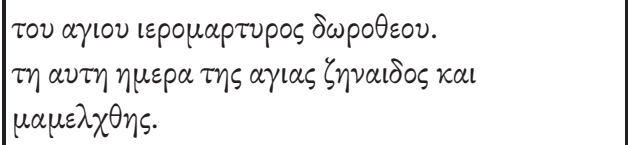 & $\begin{array}{l}\text { St Dorotheus the Hieromartyr. } \\
\text { On the same day St Zenais and } \\
\text { Mamelchtha. }\end{array}$ \\
\hline June 7 & 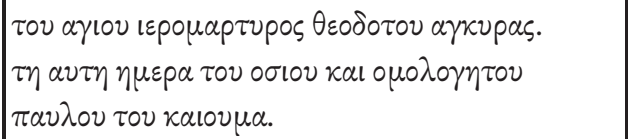 & $\begin{array}{l}\text { St Theodotus of Ancyra, Hieromartyr. } \\
\text { On the same day the holy confessor Paul of } \\
\text { Kaiouma. }\end{array}$ \\
\hline June 8 & 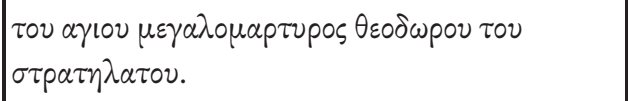 & St Theodore Stratelates the Great Martyr. \\
\hline June 9 & 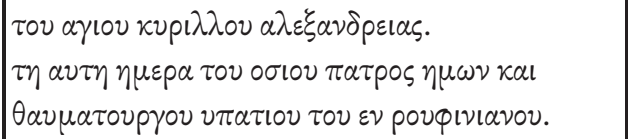 & $\begin{array}{l}\text { St Cyril of Alexandria. } \\
\text { On the same day our holy father Hypatius } \\
\text { of Rouphinianai the wonderworker. }\end{array}$ \\
\hline June 10 & 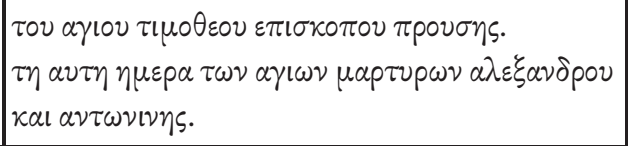 & $\begin{array}{l}\text { St Timothy Bishop of Prusa. } \\
\text { On the same day St Alexander and } \\
\text { Antonina the martyrs. }\end{array}$ \\
\hline June 11 & 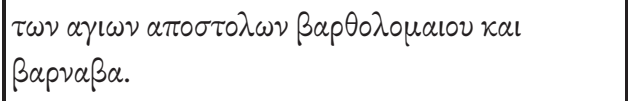 & St Bartholomew and Barnabas, Apostles. \\
\hline June 12 & 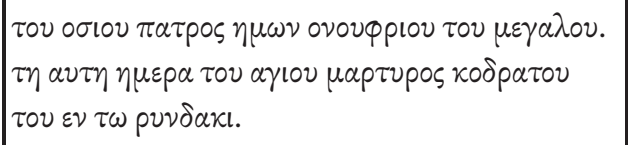 & $\begin{array}{l}\text { Our holy father Onuphrius the Great. } \\
\text { On the same day St Quadratus the martyr } \\
\text { of the Rhyndacus. }\end{array}$ \\
\hline June 13 & 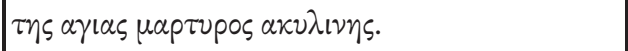 & St Aquilina the Martyr. \\
\hline June 14 & 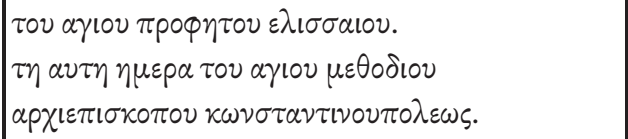 & $\begin{array}{l}\text { The sainted Prophet Elisha. } \\
\text { On the same day St Methodius Archbishop } \\
\text { of Constantinople. }\end{array}$ \\
\hline
\end{tabular}

\footnotetext{
${ }^{19}$ This refers to a processional liturgy.
} 


\begin{tabular}{|c|c|c|}
\hline Day & Heading & Commemoration \\
\hline June 15 & 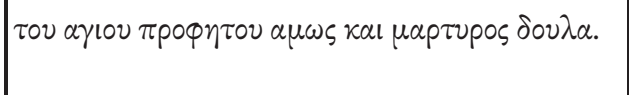 & $\begin{array}{l}\text { The sainted Prophet Amos and Doulas the } \\
\text { Martyr. }\end{array}$ \\
\hline June 16 & 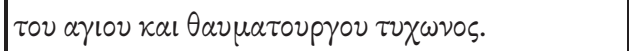 & St Tychon the wonderworker. \\
\hline June 17 & $\begin{array}{l}\tau \omega \nu \alpha \gamma(\omega \nu \mu \alpha \rho \tau \nu \rho \omega \nu \mu \alpha \nu \circ \nu \eta \lambda \sigma \alpha \beta \varepsilon \lambda \text { kal } \\
\iota \sigma \mu \alpha \eta \lambda .\end{array}$ & St Manuel, Sabel and Ismael, martyrs. \\
\hline June 18 & 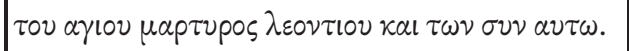 & St Leontius the Martyr and those with him. \\
\hline June 19 & 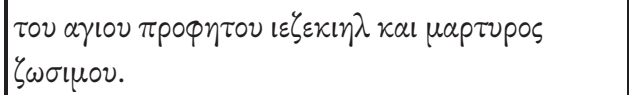 & $\begin{array}{l}\text { The sainted Prophet Ezekiel, Zosimus the } \\
\text { Martyr. }\end{array}$ \\
\hline June 20 & 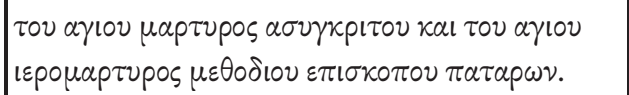 & $\begin{array}{l}\text { St Asynkritos the Martyr and St Methodius } \\
\text { Bishop of Patara, Hieromartyr. }\end{array}$ \\
\hline June 21 & 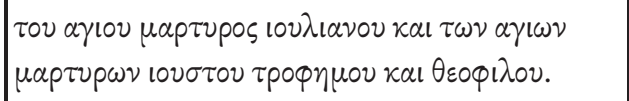 & $\begin{array}{l}\text { St Julian the Martyr and St Justus, } \\
\text { Trophimus and Theophilus, martyrs. }\end{array}$ \\
\hline June 22 & 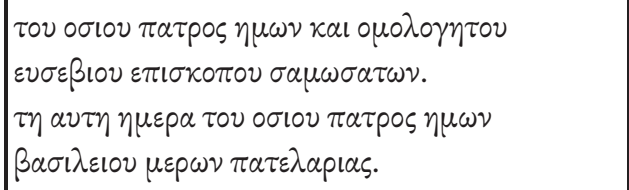 & $\begin{array}{l}\text { Our holy father Eusebius, confessor, } \\
\text { Bishop of Samosata. } \\
\text { On the same day our holy father Basil, } \\
\text { Abbot of Patalaria monastery. }\end{array}$ \\
\hline June 23 & 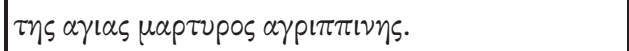 & St Agrippina the Martyr. \\
\hline June 24 & 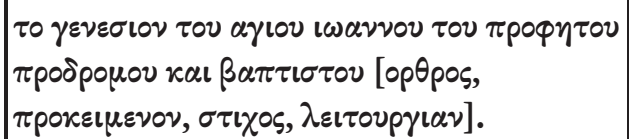 & $\begin{array}{l}\text { The Birth of St John the Prophet, } \\
\text { Forerunner and Baptist. }\end{array}$ \\
\hline June 25 & 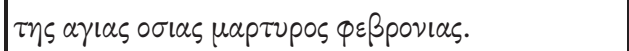 & St Febronia the holy martyr. \\
\hline June 26 & 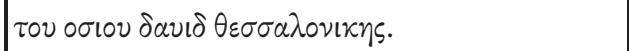 & The holy David of Thessaloniki. \\
\hline June 27 & 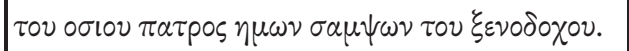 & Our holy father Sampson the hospitable. \\
\hline June 28 & 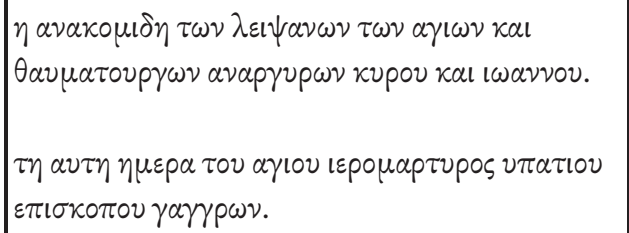 & $\begin{array}{l}\text { The translation of the relics of the } \\
\text { wonderworking and unmercenary St Cyrus } \\
\text { and John. } \\
\text { On the same day St Hypatius the } \\
\text { Hieromartyr, Bishop of Gangra. }\end{array}$ \\
\hline June 29 & 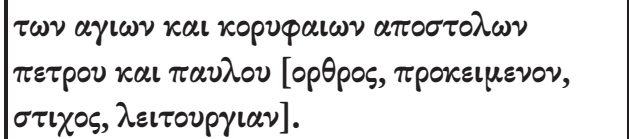 & $\begin{array}{l}\text { St Peter and Paul, leaders of the } \\
\text { apostles. }\end{array}$ \\
\hline June 30 & $\tau \omega \nu \alpha \gamma\left\llcorner\omega \nu \alpha \pi \circ \sigma \tau 0 \lambda \omega \nu \tau \omega \nu\right.$ เ $\beta^{\prime}$. & The 12 sainted Apostles. \\
\hline
\end{tabular}




\begin{tabular}{|c|c|c|}
\hline Day & Heading & Commemoration \\
\hline July 1 & 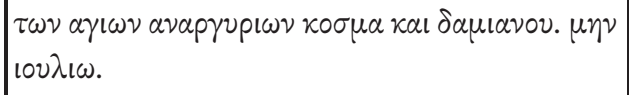 & $\begin{array}{l}\text { St Cosmas and Damian the } \\
\text { unmercenaries. }{ }^{20} \text { The month of July. }\end{array}$ \\
\hline July 2 & 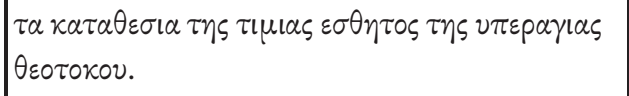 & $\begin{array}{l}\text { The deposition of the precious mantle of } \\
\text { the all-holy Mother of God. }\end{array}$ \\
\hline July 3 & 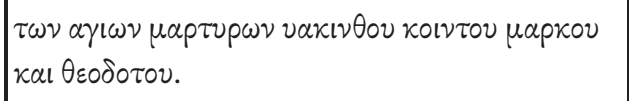 & $\begin{array}{l}\text { St Hyacinth, Quintus, Mark and } \\
\text { Theodotus, martyrs. }\end{array}$ \\
\hline July 4 & 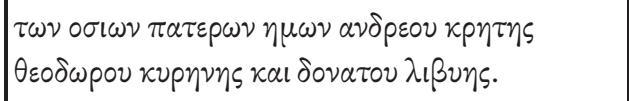 & $\begin{array}{l}\text { Our holy fathers Andrew of Crete, } \\
\text { Theodore of Cyrene and Donatus of Libya. }\end{array}$ \\
\hline July 5 & 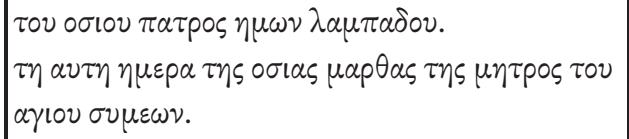 & $\begin{array}{l}\text { Our holy father Lampadus. } \\
\text { On the same day the holy Martha, mother } \\
\text { of St Symeon. }\end{array}$ \\
\hline July 6 & 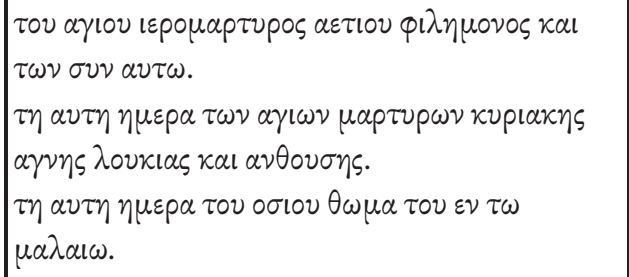 & $\begin{array}{l}\text { St Aetios the Hieromartyr, Philemon and } \\
\text { those with them. } \\
\text { On the same day St Kyriaki, Agnes, Lucia } \\
\text { and Anthousa, martyrs. } \\
\text { On the same day the holy Thomas of } \\
\text { Maleon. }\end{array}$ \\
\hline July 7 & 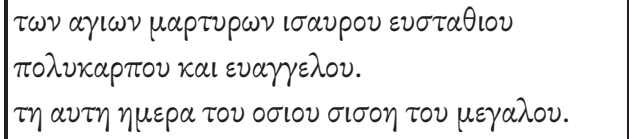 & $\begin{array}{l}\text { St Isauros, Eustathius, Polycarp and } \\
\text { Evangelos, martyrs. } \\
\text { On the same day the holy Sisoes the Great. }\end{array}$ \\
\hline July 8 & 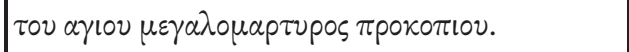 & St Procopius the Great Martyr. \\
\hline July 9 & 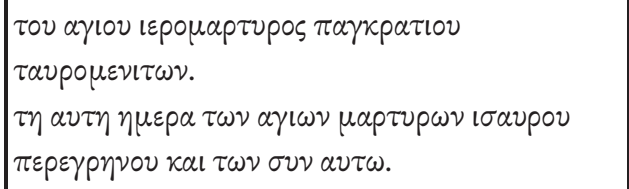 & $\begin{array}{l}\text { St Pancratius of Taormina, Hieromartyr. } \\
\text { On the same day St Isaurus, Peregrenus and } \\
\text { those with them, martyrs. }\end{array}$ \\
\hline July 10 & $\tau \omega \nu \alpha \gamma\left(\omega \nu \mu \varepsilon^{\prime} \mu \alpha \rho \tau \nu \rho \omega \nu \tau \omega \nu \varepsilon \nu \nu 1 \kappa \circ \pi 0 \lambda \varepsilon l\right.$. & The sainted 45 martyrs of Nicopolis. \\
\hline July 11 & 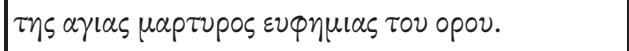 & St Euphemia of the Mountain, martyr. \\
\hline July 12 & 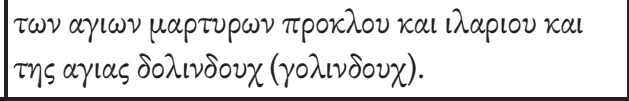 & $\begin{array}{l}\text { St Proclus and Hilary, martyrs, and St } \\
\text { Golinduc. }\end{array}$ \\
\hline July 13 & 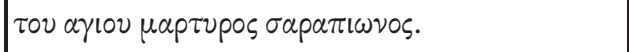 & St Serapion the Martyr. \\
\hline
\end{tabular}

\footnotetext{
${ }^{20}$ See the note on November 1.
} 


\begin{tabular}{|c|c|c|}
\hline Day & Heading & Commemoration \\
\hline July 14 & $\tau \circ \nu \alpha \gamma 10 \nu \alpha \pi \circ \sigma \tau 0 \lambda \circ \nu \alpha x \nu \lambda \alpha$ & St Aquila the Apostle. \\
\hline \multirow[t]{2}{*}{ July 15} & 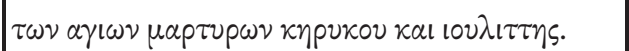 & St Cyricus ${ }^{21}$ and Julitta, martyrs. \\
\hline & 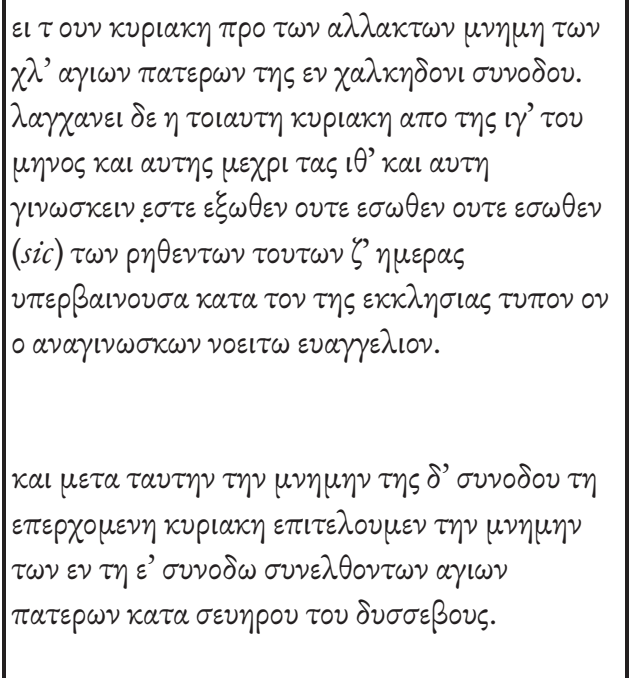 & $\begin{array}{l}\text { On the Sunday before the commemoration } \\
\text { of the } 630 \text { fathers appointed to the Synod } \\
\text { in Chalcedon. This Sunday falls between } \\
\text { the } 13 \text { th of the month until the } 19 \text { th, and } \\
\text { you are to read these words outside, not } \\
\text { inside, for seven days, stepping over } \\
\text { according to the rite of the Great Church, } \\
\text { which the Gospel reader should } \\
\text { understand. } \\
\text { And after this commemoration of the } 4 \text { th } \\
\text { Synod, on the following Sunday we } \\
\text { celebrate the commemoration of the holy } \\
\text { fathers who gathered in the 5th Synod } \\
\text { against Severus the impious. }\end{array}$ \\
\hline July 16 & 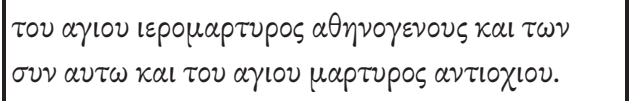 & $\begin{array}{l}\text { St Athenogenes the Hieromartyr and those } \\
\text { with him, and St Antiochus the Martyr. }\end{array}$ \\
\hline July 17 & 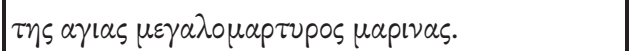 & St Marina the Great Martyr. \\
\hline July 18 & 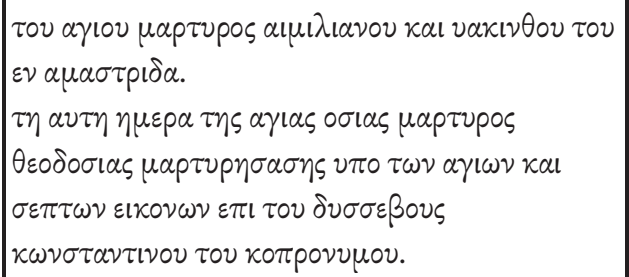 & $\begin{array}{l}\text { St Emilian the Martyr and Hyacinth of } \\
\text { Amastris. } \\
\text { On the same day St Theodosia the holy } \\
\text { martyr, martyred on account of the holy } \\
\text { and venerated icons by the impious } \\
\text { Constantine Copronymus. }\end{array}$ \\
\hline July 19 & 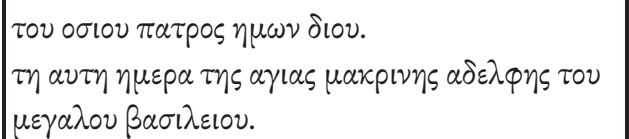 & $\begin{array}{l}\text { Our holy father Dius. } \\
\text { On the same day St Macrina sister of Basil } \\
\text { the Great. }\end{array}$ \\
\hline July 20 & 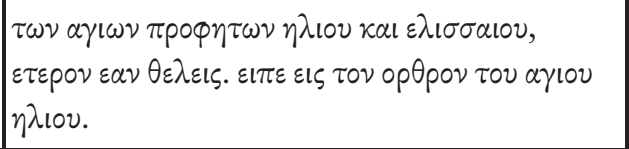 & $\begin{array}{l}\text { The sainted Prophet Elijah and Elisha. } \\
\text { An alternative if desired. Read for the } \\
\text { Matins of the sainted Elijah. }\end{array}$ \\
\hline July 21 & 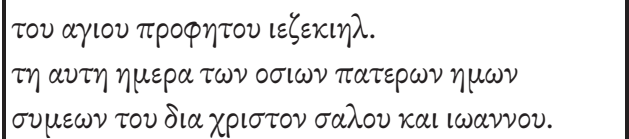 & $\begin{array}{l}\text { The sainted Prophet Ezekiel. } \\
\text { On the same day our holy fathers Symeon } \\
\text { the fool for Christ and John. }\end{array}$ \\
\hline July 22 & 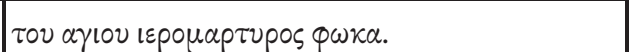 & St Phocas the Hieromartyr. \\
\hline
\end{tabular}

${ }^{21}$ Sometimes written Quiricus. 


\begin{tabular}{|c|c|c|}
\hline Day & Heading & Commemoration \\
\hline & 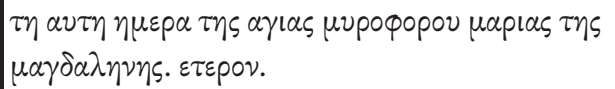 & $\begin{array}{l}\text { On the same day St Mary Magdalene the } \\
\text { Myrrh-bearer. An alternative. }\end{array}$ \\
\hline July 23 & 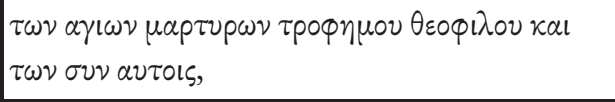 & $\begin{array}{l}\text { St Trophimos, Theophilos and those with } \\
\text { them, martyrs. }\end{array}$ \\
\hline July 24 & 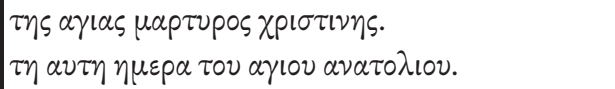 & $\begin{array}{l}\text { St Christina the Martyr. } \\
\text { On the same day St Anatolius. }\end{array}$ \\
\hline July 25 & 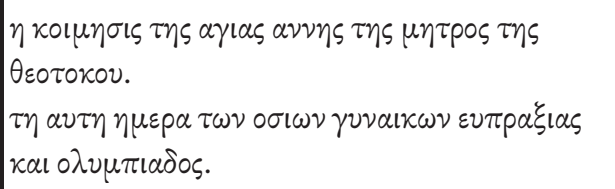 & $\begin{array}{l}\text { The dormition of St Anne, mother of the } \\
\text { Mother of God. } \\
\text { On the same day the holy women Eupraxia } \\
\text { and Olympias. }\end{array}$ \\
\hline July 26 & 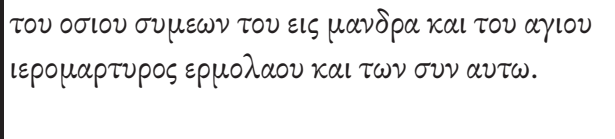 & $\begin{array}{l}\text { The holy Symeon of Mandra and St } \\
\text { Hermolaus the Hieromartyr and those with } \\
\text { him. }\end{array}$ \\
\hline July 27 & 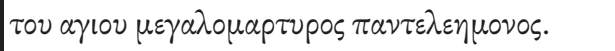 & St Panteleimon the Great Martyr. \\
\hline July 28 & 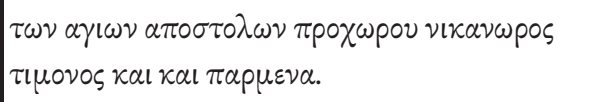 & $\begin{array}{l}\text { St Prochorus, Nicanor, Timon and } \\
\text { Parmenas, Apostles. }\end{array}$ \\
\hline July 29 & 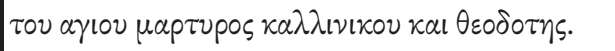 & St Kallinikos the Martyr and Theodota. \\
\hline July 30 & 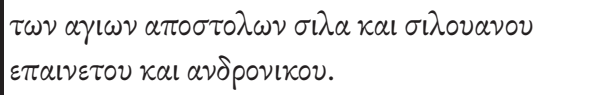 & $\begin{array}{l}\text { St Silas and Silvanus, Epenetus and } \\
\text { Andronicus, Apostles. }\end{array}$ \\
\hline July 31 & 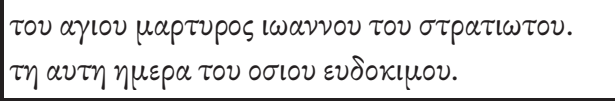 & $\begin{array}{l}\text { St John Stratiotes, martyr. } \\
\text { On the same day the holy Eudocimus. }\end{array}$ \\
\hline Aug. 1 & $\mu \eta \nu \iota \alpha v \gamma \sigma v \sigma \tau \omega \alpha^{\prime} \tau \omega \nu \alpha \gamma \iota \omega \nu \mu \alpha \kappa \kappa \alpha \beta \alpha \iota \omega \nu$. & August 1 . The sainted Maccabees. \\
\hline Aug. 2 & 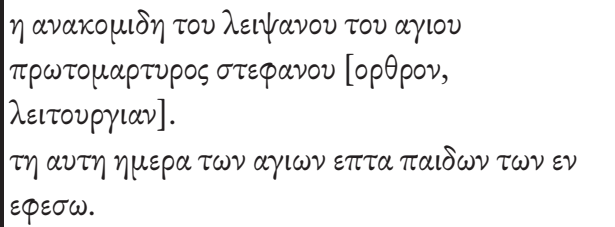 & $\begin{array}{l}\text { The deposition of the relics of St Stephen } \\
\text { the protomartyr. } \\
\text { On the same day the seven sainted children } \\
\text { of Ephesus. }\end{array}$ \\
\hline Aug. 3 & 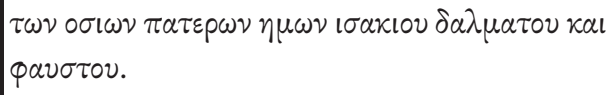 & $\begin{array}{l}\text { Our holy fathers Isaac, Dalmatius and } \\
\text { Faustus. }\end{array}$ \\
\hline Aug. 4 & 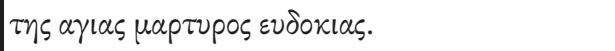 & St Eudokia the Martyr. \\
\hline Aug. 5 & 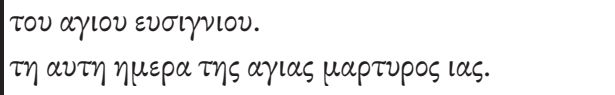 & $\begin{array}{l}\text { St Eusignius. } \\
\text { On the same day St Ia the Martyr. }\end{array}$ \\
\hline
\end{tabular}




\begin{tabular}{|c|c|c|}
\hline Day & Heading & Commemoration \\
\hline Aug. 6 & 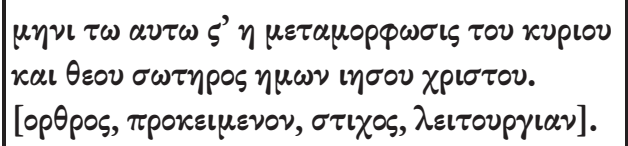 & $\begin{array}{l}\text { In the same 6th month, the } \\
\text { Transfiguration of the Lord and God, } \\
\text { Our Saviour Jesus Christ. }\end{array}$ \\
\hline Aug. 7 & 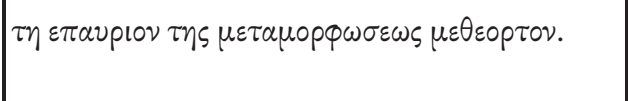 & $\begin{array}{l}\text { On the morrow of the Transfiguration } \\
\text { afterfeast. }\end{array}$ \\
\hline Aug. 8 & 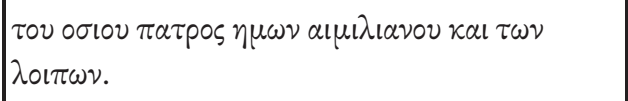 & Our holy father Emilian and the others. \\
\hline Aug. 9 & $\tau 0 \nu \alpha \gamma 10 v \alpha \pi \circ \sigma \tau 0 \lambda \circ v \mu \alpha \tau \theta \iota \alpha$ & St Matthias the Apostle. \\
\hline Aug. 10 & $\tau \circ v \alpha \gamma 10 v \mu \alpha \rho \tau \tau p \circ \varsigma$ $\lambda \alpha \nu \rho \varepsilon \nu \tau i o v$ & St Laurence the Martyr. \\
\hline Aug. 11 & 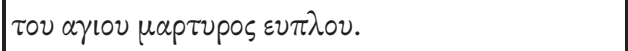 & St Euplus the Martyr. \\
\hline Aug. 12 & 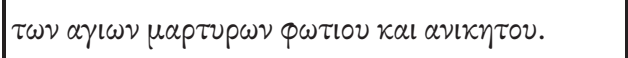 & St Photius and Anicetus the martyrs. \\
\hline Aug. 13 & 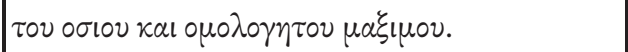 & The holy Maximus the Confessor. \\
\hline Aug. 14 & 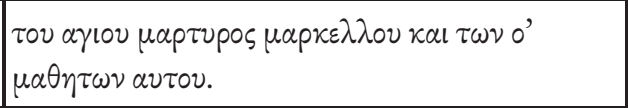 & $\begin{array}{l}\text { St Marcellus the Martyr and his } 70 \\
\text { disciples. }\end{array}$ \\
\hline Aug. 15 & 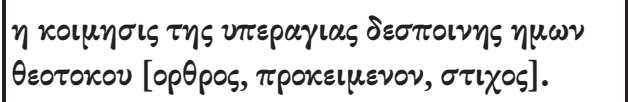 & $\begin{array}{l}\text { The Dormition of our most holy } \\
\text { Queen, the Mother of God. }\end{array}$ \\
\hline Aug. 16 & 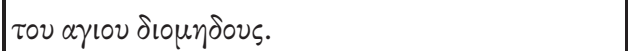 & St Diomedes. \\
\hline Aug. 17 & 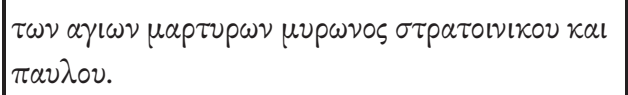 & St Myron, Stratonicus and Paul, martyrs. \\
\hline Aug. 18 & 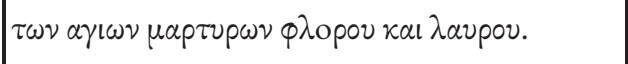 & St Florus and Laurus, martyrs. \\
\hline Aug. 19 & 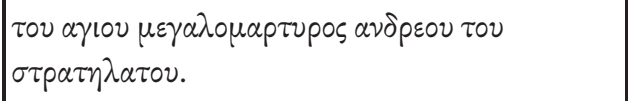 & St Andrew Stratelates, the Great Martyr. \\
\hline Aug. 20 & 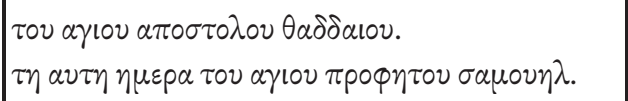 & $\begin{array}{l}\text { St Thaddeus the Apostle. On the same day } \\
\text { the sainted Prophet Samuel. }\end{array}$ \\
\hline Aug. 21 & 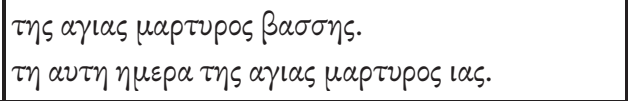 & $\begin{array}{l}\text { St Bassa the Martyr. } \\
\text { On the same day St Ia the Martyr. }\end{array}$ \\
\hline Aug. 22 & 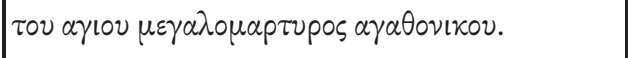 & St Agathonicus the Great Martyr. \\
\hline Aug. 23 & 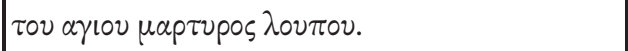 & St Lupus the Martyr. \\
\hline Aug. 24 & $\tau \circ v$ a $\gamma 10 v$ a $\pi \circ \sigma \tau 0 \lambda \circ v \beta \alpha \rho \theta 0 \lambda \circ \mu \alpha 10 v$. & St Bartholomew the Apostle. \\
\hline Aug. 25 & 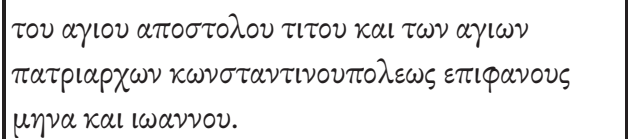 & $\begin{array}{l}\text { St Titus the Apostle and the sainted } \\
\text { Patriarchs of Constantinople Epiphanius, } \\
\text { Menas and John. }\end{array}$ \\
\hline
\end{tabular}




\begin{tabular}{|c|c|c|}
\hline Day & Heading & Commemoration \\
\hline Aug. 26 & $\tau \omega \nu \alpha \gamma l \omega \nu \mu \alpha \rho \tau \nu \rho \omega \nu \alpha \delta \rho 1 \alpha \nu \circ \nu$ kal $\nu \alpha \tau \alpha \lambda l \alpha \varsigma$. & St Adrian and Natalia, martyrs. \\
\hline Aug. 27 & 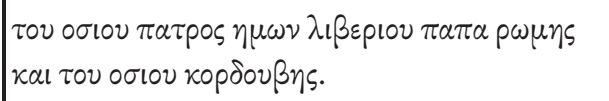 & $\begin{array}{l}\text { Our holy father Liberius Pope of Rome } \\
\text { and Hosius of Cordoba. }\end{array}$ \\
\hline Aug. 28 & 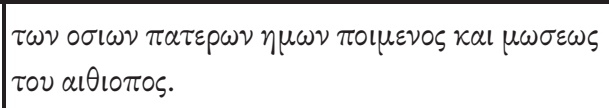 & $\begin{array}{l}\text { Our holy fathers Poemen and Moses of } \\
\text { Ethiopia. }\end{array}$ \\
\hline Aug. 29 & 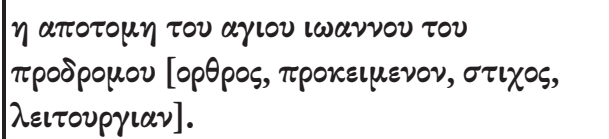 & $\begin{array}{l}\text { The beheading of St John the } \\
\text { Forerunner. }\end{array}$ \\
\hline Aug. 30 & 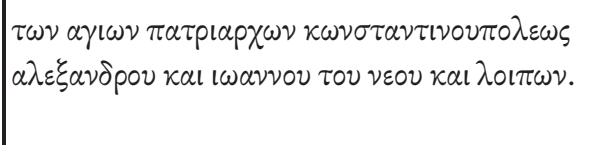 & $\begin{array}{l}\text { The sainted Patriarchs of Constantinople } \\
\text { Alexander, John the Younger and the } \\
\text { others. }\end{array}$ \\
\hline Aug. 31 & $\tau \alpha \kappa \alpha \tau \alpha \theta \varepsilon \sigma 1 \alpha \tau \eta \zeta \tau i \mu l \alpha \varsigma \zeta \omega \nu \eta \zeta$. & The deposition of the precious girdle. ${ }^{22}$ \\
\hline
\end{tabular}

\footnotetext{
${ }^{22}$ Believed to belong to the Theotokos.
} 
